Cochrane Database of Systematic Reviews

\title{
Relapse prevention interventions for smoking cessation (Review)
}

Livingstone-Banks J, Norris E, Hartmann-Boyce J, West R, Jarvis M, Chubb E, Hajek P

Livingstone-Banks J, Norris E, Hartmann-Boyce J, West R, Jarvis M, Chubb E, Hajek P.

Relapse prevention interventions for smoking cessation.

Cochrane Database of Systematic Reviews 2019, Issue 10. Art. No.: CD003999.

DOI: 10.1002/14651858.CD003999.pub6.

www.cochranelibrary.com 
TABLE OF CONTENTS

HEADER

ABSTRACT

PLAIN LANGUAGE SUMMARY

SUMMARY OF FINDINGS

BACKGROUND

OBJECTIVES

METHODS

RESULTS

Figure 1.

Figure 2.

Figure 3.

DISCUSSION

AUTHORS' CONCLUSIONS

ACKNOWLEDGEMENTS

REFERENCES

CHARACTERISTICS OF STUDIES

DATA AND ANALYSES

Analysis 1.1. Comparison 1 Behavioural interventions for abstinent pregnant/postpartum women, Outcome 1 Not smoking at delivery/last follow-up prior to delivery.

Analysis 1.2. Comparison 1 Behavioural interventions for abstinent pregnant/postpartum women, Outcome 2 Not smoking at longest follow-up after delivery.

Analysis 2.1. Comparison 2 Interventions for abstinent hospitalised smokers, Outcome 1 Behavioural interventions, cessation at longest follow-up.

Analysis 2.2. Comparison 2 Interventions for abstinent hospitalised smokers, Outcome 2 Pharmacotherapy interventions, cessation at longest follow-up.

Analysis 3.1. Comparison 3 Behavioural interventions for unaided abstainers, Outcome 1 Cessation at longest follow-up. ....... Analysis 4.1. Comparison 4 Behavioural interventions for assisted abstainers, Outcome 1 Cessation at longest follow-up. ....... Analysis 5.1. Comparison 5 Pharmacotherapy for assisted abstainers, Outcome 1 Nicotine replacement therapy versus placebo. Cessation 12 months + after quit date.

Analysis 5.2. Comparison 5 Pharmacotherapy for assisted abstainers, Outcome 2 Bupropion vs placebo. Cessation 12 months + after quit date.

Analysis 5.3. Comparison 5 Pharmacotherapy for assisted abstainers, Outcome 3 Combination NRT \& bupropion vs placebo. Cessation at longest follow-up.

Analysis 5.4. Comparison 5 Pharmacotherapy for assisted abstainers, Outcome 4 Varenicline vs placebo. Cessation 12 months + after quit date.

Analysis 5.5. Comparison 5 Pharmacotherapy for assisted abstainers, Outcome 5 Rimonabant vs placebo. Cessation 12 months + after quit date.

Analysis 6.1. Comparison 6 Pharmacotherapy for unaided abstainers, Outcome 1 Cessation 12 months after quit date.

Analysis 7.1. Comparison 7 Behavioural interventions for smokers. RP vs cessation, matched for programme length, Outcome 1 Group or individual format therapy (+/- adjunct pharmacotherapy), cessation at longest follow-up.

Analysis 7.2. Comparison 7 Behavioural interventions for smokers. RP vs cessation, matched for programme length, Outcome 2 Self-help format, cessation at longest follow-up.

Analysis 8.1. Comparison 8 Behavioural interventions for smokers. RP vs cessation, different intensity programmes, Outcome 1 Cessation at longest follow-up.

Analysis 9.1. Comparison 9 Interventions for smokers, tests of adjuncts to cessation programmes, Outcome 1 Behavioural interventions, cessation at longest follow-up.

Analysis 9.2. Comparison 9 Interventions for smokers, tests of adjuncts to cessation programmes, Outcome 2 Combined behavioural and pharma interventions, cessation at longest follow-up.

Analysis 10.1. Comparison 10 Abstinent pregnant/postpartum women subgrouped by duration of prior abstinence, Outcome 1 Not smoking at delivery/last follow-up prior to delivery.

Analysis 10.2. Comparison 10 Abstinent pregnant/postpartum women subgrouped by duration of prior abstinence, Outcome 2 Not smoking at longest follow-up after delivery.

Analysis 11.1. Comparison 11 Abstinent hospitalised smokers subgrouped by duration of prior abstinence, Outcome 1 Behavioural interventions, cessation at longest follow-up. 
Analysis 11.2. Comparison 11 Abstinent hospitalised smokers subgrouped by duration of prior abstinence, Outcome 2 Pharmacotherapy interventions, cessation at longest follow-up.

Analysis 12.1. Comparison 12 Unaided abstainers subgrouped by duration of prior abstinence - Behavioural interventions, Outcome 1 Behavioural interventions for unaided abstainers.

Analysis 13.1. Comparison 13 Assisted abstainers subgrouped by duration of prior abstinence - Behavioural interventions, Outcome 1 Behavioural interventions for assisted abstainers.

Analysis 14.1. Comparison 14 Unaided abstainers subgrouped by duration of prior abstinence - Pharmacotherapy, Outcome 1 Nicotine gum vs placebo for unaided abstainers.

Analysis 15.1. Comparison 15 Assited abstainers subgrouped by duration of prior abstinence - Pharmacotherapy, Outcome 1 Nicotine replacement therapy versus placebo. Cessation 12 months + after quit date.

Analysis 15.2. Comparison 15 Assited abstainers subgrouped by duration of prior abstinence - Pharmacotherapy, Outcome 2 Bupropion vs placebo. Cessation 12 months + after quit date.

Analysis 15.3. Comparison 15 Assited abstainers subgrouped by duration of prior abstinence - Pharmacotherapy, Outcome 3 Combination NRT \& bupropion vs placebo. Cessation at longest follow-up.

Analysis 15.4. Comparison 15 Assited abstainers subgrouped by duration of prior abstinence - Pharmacotherapy, Outcome 4 Varenicline vs placebo. Cessation 12 months + after quit date.

Analysis 15.5. Comparison 15 Assited abstainers subgrouped by duration of prior abstinence - Pharmacotherapy, Outcome 5 Rimonabant vs placebo. Cessation 12 months + after quit date.

ADDITIONAL TABLES

APPENDICES

WHAT'S NEW

HISTORY 
[Intervention Review]

\section{Relapse prevention interventions for smoking cessation}

Jonathan Livingstone-Banks ${ }^{1}$, Emma Norris² ${ }^{2}$ Jamie Hartmann-Boyce ${ }^{1}$, Robert West ${ }^{3}$, Martin Jarvis ${ }^{4}$, Emma Chubb ${ }^{5}$, Peter Hajek ${ }^{6}$

${ }^{1}$ Nuffield Department of Primary Care Health Sciences, University of Oxford, Oxford, UK. ${ }^{2}$ Centre for Behaviour Change, University College London, London, UK. ${ }^{3}$ Department of Behavioural Science and Health, University College London, London, UK. ${ }^{4}$ Health Behavior Research Centre of Cancer Research UK, Department of Epidemiology and Public Health, University College London, London, UK. ${ }^{5}$ School of Psychology, Cardiff University, Cardiff, UK. 6 Wolfson Institute of Preventive Medicine, Barts \& The London School of Medicine and Dentistry, Queen Mary University of London, London, UK

Contact address: Jonathan Livingstone-Banks, Nuffield Department of Primary Care Health Sciences, University of Oxford, Oxford, UK. jonathan.livingstone-banks@phc.ox.ac.uk.

Editorial group: Cochrane Tobacco Addiction Group.

Publication status and date: New search for studies and content updated (no change to conclusions), published in Issue 10, 2019.

Citation: Livingstone-Banks J, Norris E, Hartmann-Boyce J, West R, Jarvis M, Chubb E, Hajek P. Relapse prevention interventions for smoking cessation. Cochrane Database of Systematic Reviews 2019, Issue 10. Art. No.: CD003999. DOI: 10.1002/14651858.CD003999.pub6.

Copyright ( 2019 The Cochrane Collaboration. Published by John Wiley \& Sons, Ltd.

\section{A B S T R A C T}

\section{Background}

A number of treatments can help smokers make a successful quit attempt, but many initially successful quitters relapse over time. Several interventions have been proposed to help prevent relapse.

\section{Objectives}

To assess whether specific interventions for relapse prevention reduce the proportion of recent quitters who return to smoking.

\section{Search methods}

We searched the Cochrane Tobacco Addiction Group trials register, clinicaltrials.gov, and the ICTRP in May 2019 for studies mentioning relapse prevention or maintenance in their title, abstracts, or keywords.

\section{Selection criteria}

Randomised or quasi-randomised controlled trials of relapse prevention interventions with a minimum follow-up of six months. We included smokers who quit on their own, were undergoing enforced abstinence, or were participating in treatment programmes. We included studies that compared relapse prevention interventions with a no intervention control, or that compared a cessation programme with additional relapse prevention components with a cessation programme alone.

\section{Data collection and analysis}

We used standard methodological procedures expected by Cochrane.

\section{Main results}

We included 81 studies (69,094 participants), five of which are new to this update. We judged 22 studies to be at high risk of bias, 53 to be at unclear risk of bias, and six studies to be at low risk of bias. Fifty studies included abstainers, and 30 studies helped people to quit and then tested treatments to prevent relapse. Twenty-eight studies focused on special populations who were abstinent because of pregnancy (19 studies), hospital admission (six studies), or military service (three studies). Most studies used behavioural interventions that tried to teach people skills to cope with the urge to smoke, or followed up with additional support. Some studies tested extended pharmacotherapy.

We focused on results from those studies that randomised abstainers, as these are the best test of relapse prevention interventions. Of the 12 analyses we conducted in abstainers, three pharmacotherapy analyses showed benefits of the intervention: extended varenicline in 
assisted abstainers ( 2 studies, $\mathrm{n}=1297$, risk ratio (RR) $1.23,95 \%$ confidence interval $(\mathrm{Cl}) 1.08$ to $1.41, \mathrm{l}=82 \%$; moderate-certainty evidence), rimonabant in assisted abstainers ( 1 study, $\mathrm{RR} 1.29,95 \% \mathrm{Cl} 1.08$ to 1.55), and nicotine replacement therapy (NRT) in unaided abstainers (2 studies, $n=2261$, RR $1.24,95 \% \mathrm{Cl} 1.04$ to $1.47, \mathrm{l}^{2}=56 \%$ ). The remainder of analyses of pharmacotherapies in abstainers had wide confidence intervals consistent with both no effect and a statistically significant effect in favour of the intervention. These included NRT in hospital inpatients ( 2 studies, $\mathrm{n}=1078, \mathrm{RR} 1.23,95 \% \mathrm{Cl} 0.94$ to $1.60, \mathrm{l} 2=0 \%$ ), NRT in assisted abstainers ( 2 studies, $\mathrm{n}=553, \mathrm{RR} 1.04,95 \% \mathrm{Cl} 0.77$ to $1.40, \mathrm{I}^{2}=0 \%$; low-certainty evidence), extended bupropion in assisted abstainers ( 6 studies, $\mathrm{n}=1697, \mathrm{RR} 1.15,95 \% \mathrm{Cl} 0.98$ to $1.35, \mathrm{I}=0 \%$; moderate-certainty evidence), and bupropion plus NRT ( 2 studies, $n=243$, RR 1.18, $95 \% \mathrm{Cl} 0.75$ to $1.87, \mathrm{I}^{2}=66 \%$; low-certainty evidence). Analyses of behavioural interventions in abstainers did not detect an effect. These included studies in abstinent pregnant and postpartum women at the end of pregnancy ( 8 studies, $\mathrm{n}=1523, \mathrm{RR} 1.05,95 \% \mathrm{Cl} 0.99$ to $1.11, \mathrm{l} 2=0 \%$ ) and at postpartum follow-up ( $15 \mathrm{studies,} \mathrm{n}=4606$, RR $1.02,95 \% \mathrm{Cl} 0.94$ to $1.09, \mathrm{I}^{2}=3 \%$ ), studies in hospital inpatients ( 5 studies, $\mathrm{n}=1385, \mathrm{RR} 1.10,95 \% \mathrm{Cl} 0.82$ to $1.47, \mathrm{I}^{2}=58 \%$ ), and studies in assisted abstainers ( 11 studies, $\mathrm{n}=5523$, RR $0.98,95 \% \mathrm{Cl} 0.87$ to $1.11, \mathrm{l} 2=52 \%$; moderate-certainty evidence) and unaided abstainers (5 studies, $\mathrm{n}=3561$, $\mathrm{RR} 1.06,95 \% \mathrm{Cl} 0.96$ to $1.16,12=1 \%)$ from the general population.

\section{Authors' conclusions}

Behavioural interventions that teach people to recognise situations that are high risk for relapse along with strategies to cope with them provided no worthwhile benefit in preventing relapse in assisted abstainers, although unexplained statistical heterogeneity means we are only moderately certain of this. In people who have successfully quit smoking using pharmacotherapy, there were mixed results regarding extending pharmacotherapy for longer than is standard. Extended treatment with varenicline helped to prevent relapse; evidence for the effect estimate was of moderate certainty, limited by unexplained statistical heterogeneity. Moderate-certainty evidence, limited by imprecision, did not detect a benefit from extended treatment with bupropion, though confidence intervals mean we could not rule out a clinically important benefit at this stage. Low-certainty evidence, limited by imprecision, did not show a benefit of extended treatment with nicotine replacement therapy in preventing relapse in assisted abstainers. More research is needed in this area, especially as the evidence for extended nicotine replacement therapy in unassisted abstainers did suggest a benefit.

\section{PLAIN LANGUAGE S UMARY}

Do any treatments help people who have successfully quit smoking to avoid starting smoking again?

\section{Background}

Some people start smoking again shortly after quitting and are said to have 'relapsed'. Treatments used to help people avoid relapse usually focus on teaching the skills to cope with temptations to smoke, but can also involve extending the length of the treatment that helped them to quit, or giving additional treatment, like follow-up calls, leaflets, or stop-smoking medicine. We set out to see if these types of approaches can be helpful, either for people who quit on their own or with the help of treatment, or for those who quit because they were pregnant or in hospital.

\section{Study characteristics}

We updated our searches of research databases in May 2019. We found 81 studies that tested various ways of trying to help people who had recently quit smoking not to relapse. Five of them were new for this update. Fifty studies included people who had already quit, and 30 studies helped people to quit and then tested treatments to prevent relapse. Twenty-eight studies focused on people who needed to stop smoking for a limited period of time because they were pregnant (19 studies), in hospital (six studies), or because of military service (three studies). Most of the studies used behavioural support treatments that tried to teach people skills to cope with the urge to smoke, or followed up with additional leaflets or calls, internet or mobile phone resources, or additional counselling. Some studies tested extending the use of medicines for helping people to quit smoking, in the hope of preventing relapse.

\section{Key results}

The evidence we found does not support the use of behavioural treatments to help prevent relapse after quitting smoking. This result was the same in all of the different groups of people studied. The most promising treatments involved extending treatment with stop-smoking medicine, in particular, varenicline. Extending treatment with bupropion did not appear to help and there was not enough evidence on extending treatment with nicotine replacement therapy.

\section{Certainty of the evidence}

For behavioural treatments, the certainty of the evidence was moderate. This is because of the diversity of results among studies. The certainty of evidence for treatments with quit-smoking medicines varied. There was moderate-certainty evidence for varenicline, moderate-certainty evidence for bupropion, and low-certainty evidence for nicotine replacement therapy (NRT), and for NRT and bupropion together. Certainty in the evidence was limited by small study sizes. 
SUMMARY OF FINDINGS

\section{Summary of findings for the main comparison. Behavioural interventions for assisted abstainers}

Behavioural interventions for relapse prevention for people who have quit smoking using a cessation intervention

Patient or population: people who have quit smoking using a cessation intervention

Intervention: behavioural interventions for relapse prevention

\begin{tabular}{|c|c|c|c|c|c|c|}
\hline \multirow[t]{3}{*}{ Outcomes } & \multicolumn{2}{|c|}{ Illustrative comparative risks* $(95 \% \mathrm{Cl})$} & \multirow{3}{*}{$\begin{array}{l}\text { Relative effect } \\
(95 \% \mathrm{CI})\end{array}$} & \multirow{3}{*}{$\begin{array}{l}\text { No of partici- } \\
\text { pants } \\
\text { (studies) }\end{array}$} & \multirow{3}{*}{$\begin{array}{l}\text { Certainty of the } \\
\text { evidence } \\
\text { (GRADE) }\end{array}$} & \multirow[t]{3}{*}{ Comments } \\
\hline & Assumed risk & Corresponding risk & & & & \\
\hline & Control & $\begin{array}{l}\text { Behavioural interventions for re- } \\
\text { lapse prevention }\end{array}$ & & & & \\
\hline \multirow{2}{*}{$\begin{array}{l}\text { Smoking cessa- } \\
\text { tion } \\
\text { Follow-up: } 9 \text { to } 15 \\
\text { months }\end{array}$} & \multicolumn{2}{|c|}{ Study population (average) } & \multirow{2}{*}{$\begin{array}{l}\text { RR } 0.98 \\
(0.87 \text { to } 1.11)\end{array}$} & \multirow{2}{*}{$\begin{array}{l}5523 \\
\text { (11 studies) }\end{array}$} & \multirow{2}{*}{$\begin{array}{l}\oplus \oplus \oplus \odot \\
\text { moderate } \\
1,2\end{array}$} & \\
\hline & 322 per 1000 & $\begin{array}{l}\mathbf{3 1 6} \text { per } \mathbf{1 0 0 0} \\
\text { (293 to } 357)\end{array}$ & & & & \\
\hline
\end{tabular}

*The basis for the assumed risk (e.g. the median control group risk across studies) is provided in footnotes. The corresponding risk (and its $95 \%$ confidence interval) is based on the assumed risk in the comparison group and the relative effect of the intervention (and its $95 \% \mathrm{Cl}$ ).

Cl: Confidence interval; RR: Risk ratio.

GRADE Working Group grades of evidence:

High certainty: Further research is very unlikely to change our confidence in the estimate of effect.

Moderate certainty: Further research is likely to have an important impact on our confidence in the estimate of effect and may change the estimate.

Low certainty: Further research is very likely to have an important impact on our confidence in the estimate of effect and is likely to change the estimate.

Very low certainty: We are very uncertain about the estimate.

1The majority of included studies judged to be at unclear or high risk of bias in two or more domains. However, as this would likely bias the results towards favouring the intervention, and the results did not favour the intervention, we did not downgrade the evidence on the grounds that we could still be confident that there was not a positive effect.

2Downgraded one level for inconsistency: unexplained statistical heterogeneity $\left(I^{2}=52 \%\right)$

\section{Summary of findings 2. Pharmacotherapy for assisted abstainers}

\section{Pharmacotherapy for relapse prevention for people who have quit smoking using a cessation intervention}

Patient or population: people who have quit smoking using a cessation intervention

Intervention: pharmacotherapy for relapse prevention 


\begin{tabular}{|c|c|c|c|c|c|c|}
\hline \multirow[t]{3}{*}{ Outcomes } & \multicolumn{2}{|c|}{ Illustrative comparative risks* $(95 \% \mathrm{CI})$} & \multirow{3}{*}{$\begin{array}{l}\text { Relative effect } \\
(95 \% \mathrm{Cl})\end{array}$} & \multirow{3}{*}{$\begin{array}{l}\text { No of partici- } \\
\text { pants } \\
\text { (studies) }\end{array}$} & \multirow{3}{*}{$\begin{array}{l}\text { Certainty of } \\
\text { the evidence } \\
\text { (GRADE) }\end{array}$} & \multirow[t]{3}{*}{ Comments } \\
\hline & Assumed risk & Corresponding risk & & & & \\
\hline & Control & $\begin{array}{l}\text { Pharmacotherapy for relapse pre- } \\
\text { vention }\end{array}$ & & & & \\
\hline \multirow{2}{*}{$\begin{array}{l}\text { NRT versus placebo Smoking } \\
\text { cessation } \\
\text { Follow-up: } 12 \text { to } 15 \text { months }\end{array}$} & \multicolumn{2}{|c|}{ Study population (average) } & \multirow{2}{*}{$\begin{array}{l}\text { RR } 1.04 \\
(0.77 \text { to } 1.4)\end{array}$} & \multirow{2}{*}{$\begin{array}{l}553 \\
\text { ( } 2 \text { studies) }\end{array}$} & \multirow{2}{*}{$\begin{array}{l}\oplus \oplus \odot \odot \\
\text { low }^{1}\end{array}$} & \\
\hline & 234 per 1000 & $\begin{array}{l}\mathbf{3 1 2} \text { per } \mathbf{1 0 0 0} \\
(231 \text { to } 420)\end{array}$ & & & & \\
\hline \multirow{2}{*}{$\begin{array}{l}\text { Bupropion versus placebo } \\
\text { Smoking cessation } \\
\text { Follow-up: } 12 \text { to } 24 \text { months }\end{array}$} & \multicolumn{2}{|c|}{ Study population (average) } & \multirow{2}{*}{$\begin{array}{l}\text { RR } 1.15 \\
\text { (0.98 to } 1.35)\end{array}$} & \multirow{2}{*}{$\begin{array}{l}1697 \\
\text { (6 studies) }\end{array}$} & \multirow{2}{*}{$\begin{array}{l}\oplus \oplus \oplus \ominus \\
\text { moderate }^{2}\end{array}$} & \\
\hline & 243 per 1000 & $\begin{array}{l}\mathbf{3 4 5} \text { per } \mathbf{1 0 0 0} \\
(294 \text { to } 405)\end{array}$ & & & & \\
\hline \multirow{2}{*}{$\begin{array}{l}\text { Combination NRT \& bupropi- } \\
\text { on versus placebo Smoking } \\
\text { cessation } \\
\text { Follow-up: } 12 \text { to } 15 \text { months }\end{array}$} & \multicolumn{2}{|c|}{ Study population (average) } & \multirow{2}{*}{$\begin{array}{l}\text { RR } 1.18 \\
(0.75 \text { to } 1.87)\end{array}$} & \multirow{2}{*}{$\begin{array}{l}243 \\
\text { (2 studies) }\end{array}$} & \multirow{2}{*}{$\begin{array}{l}\oplus \oplus \ominus \ominus \\
\text { low }^{1}\end{array}$} & \\
\hline & 215 per 1000 & $\begin{array}{l}\mathbf{3 5 4} \text { per } \mathbf{1 0 0 0} \\
(225 \text { to } 561)\end{array}$ & & & & \\
\hline \multirow{2}{*}{$\begin{array}{l}\text { Varenicline versus placebo } \\
\text { Smoking cessation }\end{array}$} & \multicolumn{2}{|c|}{ Study population (average) } & \multirow{2}{*}{$\begin{array}{l}\text { RR } 1.23 \\
(1.08 \text { to } 1.41)\end{array}$} & \multirow{2}{*}{$\begin{array}{l}1297 \\
\text { (2 studies) }\end{array}$} & \multirow{2}{*}{$\begin{array}{l}\oplus \oplus \oplus \ominus \\
\text { moderate }^{3}\end{array}$} & \\
\hline & 356 per 1000 & $\begin{array}{l}\mathbf{4 3 8} \text { per } 1000 \\
\text { (388 to } 509)\end{array}$ & & & & \\
\hline
\end{tabular}

*The basis for the assumed risk (e.g. the median control group risk across studies) is provided in footnotes. The corresponding risk (and its $95 \%$ confidence interval) is based on the assumed risk in the comparison group and the relative effect of the intervention (and its $95 \% \mathrm{Cl}$ ).

Cl: Confidence interval; RR: Risk ratio.

GRADE Working Group grades of evidence:

High certainty: Further research is very unlikely to change our confidence in the estimate of effect.

Moderate certainty: Further research is likely to have an important impact on our confidence in the estimate of effect and may change the estimate.

Low certainty: Further research is very likely to have an important impact on our confidence in the estimate of effect and is likely to change the estimate.

Very low certainty: We are very uncertain about the estimate.

1 Downgraded two levels for imprecision: total number of events $<100$

2 Downgraded one level for imprecision: confidence intervals incorporated possibility of no effect and clinically significant effect

3 Downgraded one level for imprecision: high level of statistical heterogeneity $(12=82 \%)$. While both studies found statistically significant benefits in favour of the intervention, heterogeneity limited confidence in the precise effect estimate. 


\section{B A C K G R O U N D}

\section{Description of the condition}

A number of interventions can help people who smoke to quit. These include pharmacological treatments, such as nicotine replacement, some antidepressants (e.g. bupropion) and nicotine receptor partial agonists (e.g. varenicline); and behavioural approaches, whether delivered individually or in groups (Hughes 2014; Lancaster 2017; Stead 2017; Hartmann-Boyce 2018). These interventions increase long-term quit rates compared with control interventions, but there is a steady attrition in overall success rates due to a proportion of initially successful participants returning to smoking over time (relapsing).

\section{Description of the intervention}

Relapse prevention interventions can include behavioural support or extended use of smoking cessation medications, or both. There is no clear definition of a relapse prevention intervention as distinct from an extended cessation treatment because, in principle, resumption of smoking at any time after the quit date can count as relapse. In general, relapse prevention is considered to apply to interventions that explicitly seek to reduce relapse rates after an acute treatment phase is successfully completed, or at some time after the quit date. The duration of the acute treatment phase varies, leading to variability in the point at which measurement of a relapse prevention effect begins.

Studies of interventions for relapse prevention may randomly assign people who have already quit, or they may randomly assign smokers before their quit attempt and provide a general smoking cessation intervention to all participants, in addition to an extra component provided for those randomly assigned to relapse prevention. The former design has a number of methodological strengths, which are discussed later in this review. We have included both types of study in the review.

\section{How the intervention might work}

There are several strategies for helping to prevent relapse. These typically aim to prevent initial lapses, prevent any lapses form leading to full relapse, or both. The most widely studied has been the skills approach, whereby participants learn to identify high-risk situations for relapse and are provided with cognitive and behavioural strategies to cope with these situations (Marlatt 1985; Marlatt 2008). Quitters can also be encouraged to 'embrace a smoke-free lifestyle' (Segan 2008). Alternative behavioural interventions (often implemented in combination with the skills approach) include imaginary cue exposure, writing tasks, aversive smoking, role-play, social support, and exercise. Recently, attempts have been made to provide common-sense relapse prevention advice (e.g. reminders about the reasons for and importance of remaining abstinent, avoiding triggers to smoking, advice on coping with urges to smoke, and mood management) via mobile applications and social media (Cheung 2015; Hicks 2017), where it can be supplemented by peer support. Alternatively, relapse prevention might be assisted by extending the duration of therapeutic contact used to aid initial cessation (Segan 2011). Finally, the use of pharmacotherapy, either by extending duration of initial cessation treatment, or by administering to those already abstinent, may help to prevent relapse by alleviating cravings (Schnoll 2015).

\section{Why it is important to do this review}

To sustain the positive health effects of quitting smoking, it is important to prevent relapse. A number of interventions have been hypothesised as potential relapse prevention tools and these need to be investigated so that healthcare providers, healthcare systems, and people who smoke can make informed decisions about the best ways to help ensure short-term quitting can be sustained in the longer term.

\section{O B JECT IVES}

To assess whether specific interventions for relapse prevention reduce the proportion of recent quitters who return to smoking.

\section{METHODS}

\section{Criteria for considering studies for this review}

\section{Types of studies}

Randomised or quasi-randomised controlled trials with a minimum follow-up of six months from quit date.

\section{Types of participants}

We considered three types of participants: people who had quit smoking on their own; people who were undergoing enforced abstinence (e.g. hospitalised, military training), whether or not they intended to quit permanently; and smokers participating in treatment programmes to assist initial cessation.

\section{Types of interventions}

We included interventions identified by study investigators as intended to prevent relapse, compared with no intervention or a shorter intervention or an intervention not oriented towards relapse prevention. We considered behavioural interventions delivered in any format, including group meetings, face-to-face sessions, written or other materials, proactive or reactive telephone support, and pharmacological interventions.

\section{Types of outcome measures}

The preferred outcome was prolonged or multiple point prevalence abstinence at follow-up of at least six months since randomisation. We also included studies that reported only point prevalence abstinence (number of participants not smoking at the point when assessment was made but not necessarily continuously since treatment) at six months or longer. For studies that reported more than one definition of abstinence, we considered whether the choice of outcome would affect any pooled effect estimate. We excluded studies with less than six months follow-up.

\section{Search methods for identification of studies}

We searched the Cochrane Tobacco Addiction Group register of trials, which includes the results of comprehensive searches of electronic bibliographic databases and conference abstracts, and the clinical trials registries clinicaltrials.gov and the ICTRP. We checked for relevance all reports of studies with 'relapse prevention' or 'maintenance' or 'relapse near prevent*' in title, abstract or keywords. See Appendix 1 for the full strategy. At the time of the search in May 2019, the Register included the results of searches of the Cochrane Central Register of Controlled trials (CENTRAL), issue 1, 2018; MEDLINE (via OVID) to update 20190409; 
Embase (via OVID) to week 201915; PsycINFO (via OVID) to update 20190401. See the Tobacco Addiction Group website for full search strategies and list of other resources searched.

\section{Data collection and analysis}

\section{Selection of studies}

In this update, two review authors (from JLB, EN and EC) identified potentially eligible studies for inclusion. We included studies that randomly assigned people already abstaining from smoking. In studies that randomly assigned smokers before quitting, almost all behavioural interventions included relapse prevention components. Therefore, in studies that randomly assigned smokers, we included only studies that explicitly identified in their titles or abstracts a focus on relapse prevention or maintenance. Unless abstainers were randomly assigned, we did not include studies of exercise, aversive smoking, or incentives because the interventions used are similar, whether described as relapse prevention or not, and are covered in separate Cochrane Reviews (Hajek 2001a; Ussher 2012; Notley 2019). We excluded most interventions for hospitalised participants because studies generally did not describe whether participants were already abstinent or not, and interventions typically contained a mixture of cessation and relapse prevention components. Studies of this type are also covered by a separate review (Rigotti 2012).

\section{Data extraction and management}

For this update, two review authors (from JLB, EN and EC) performed data extraction in duplicate on all new eligible studies. We reported the following study characteristics in the 'Characteristics of included studies' table:

- Country and setting in which study was undertaken, including population targeted for recruitment;

- Methods of randomisation, allocation concealment, and blinding;

- Demographics of participants, including age, sex, baseline cigarette consumption, and period of prior quitting, if relevant;

- Intervention components, including numbers and types of contacts and periods of contact

- Control condition(s);

- Outcome, including length of follow-up, definition(s) of cessation used in review, and any other measures used;

- Validation of self-reported smoking status, including method used, and cut-off point for biochemical validation.

\section{Assessment of risk of bias in included studies}

We assessed all included studies for risk of bias using the Cochrane 'Risk of Bias' tool. We assessed each study's risk of bias on five domains: random sequence generation; allocation concealment; blinding of participants and personnel; blinding of outcome assessment; and incomplete outcome data. We noted other risks of bias, where relevant. Studies that provided insufficient information on which to make judgements were coded as 'unclear' in the relevant domains. Studies were considered to be at high risk of attrition bias (incomplete outcome data) when lack of information meant that we were unable to include postrandomisation dropouts in our denominators, or when less than $50 \%$ of participants were followed up at six months or longer, or when there was a difference in follow-up rate of $20 \%$ or more.
Had studies of pharmacotherapies not used placebo, we would have considered these to be at high risk of performance bias (blinding of participants/personnel), but in the case of behavioural interventions where blinding of participants was not possible, we judged other study characteristics such as similar amounts of contact between conditions, or participants not knowing about other conditions, which may indicate that performance bias is less likely. We judged studies to be at high risk of detection bias (blinding of outcomes assessors) when no biochemical validation was used and the intervention arm received more face-to-face contact than the control arm, as we considered differential misreport a possibility in these cases.

\section{Measures of treatment effect}

The primary outcome was the number of quitters at the longest follow-up. We used biochemically validated cessation in preference to self-report, where available. When given a choice, we included continuous abstinence in preference to point prevalence abstinence. Randomly assigned participants who withdrew, were lost to follow-up, or failed to provide samples for validation were usually classified as relapsers or continuing smokers. We noted any exceptions to this in the study details.

\section{Dealing with missing data}

In the protocol for this review, we planned to approach authors to ask for additional data about end of treatment quit rates and long-term quit rates in early quitters. In view of the heterogeneity of interventions, timing of assessments, and ways of defining abstinence, we decided that additional data, even if suitable and available, would not strengthen the review.

\section{Assessment of heterogeneity}

To investigate heterogeneity, we used the $\mathrm{I}^{2}$ statistic, given by the formula $[(\mathrm{Q}-\mathrm{df}) / \mathrm{Q}] \times 100 \%$, where $\mathrm{Q}$ is the $\mathrm{Chi}^{2}$ statistic and $d f$ is its degrees of freedom (Higgins 2003). This describes the percentage of variability in effect estimates that is due to heterogeneity rather than to sampling error (chance). A value greater than $50 \%$ may be considered to indicate substantial heterogeneity.

\section{Data synthesis}

We used risk ratios to summarise individual study outcomes and to determine estimates of pooled effect. In line with new Cochrane Tobacco Addiction Group policy, for comparisons of behavioural interventions, we estimated a pooled weighted average of risk ratios with $95 \%$ confidence intervals, using a Mantel-Haenszel random-effects model to account for the expected variability in the interventions delivered; for comparisons of pharmacological interventions, we used a fixed-effect model. Had a study reported an odds ratio corrected for clustering or baseline imbalance, and where we were unable to derive a risk ratio, we planned to pool odds ratios for studies in the same subgroup of a comparison using the inverse variance method to check whether there was an effect on the results.

\section{Subgroup analysis and investigation of heterogeneity}

We planned not to pool results from studies that randomly assigned abstainers with results from those that randomly assigned smokers, but we made two exceptions to this: see discussion of Killen 2006 and Wetter 2011 in Description of studies. Our predefined subgroups were based on the type and intensity of 
intervention. We separated studies in which contact time was matched from those in which relapse prevention included a longer duration of contact.

Other prespecified subgroups included studies of spontaneous quitters, such as pregnant women, and of smokers seeking smoking cessation treatment. We added further subgroup analyses to distinguish between longer (longer than four weeks) and shorter intervention and control durations. We also considered subgroup analyses for 'skills' and social support studies. This replaced our planned subgroup division based on the format of the intervention (group versus individual) as this was more relevant within the available sample of studies.

At the request of NICE (the National Institute for Health and Care Excellence; the guideline development organisation for England and Wales), for analyses of studies randomising abstainers, we conducted subgroup analyses grouping studies by the duration of prior abstinence of participants. We grouped studies based on whether participants had been abstinent for four or more weeks, less than four weeks, or if prior abstinence varied or was not adequately specified.

\section{Summary of findings table}

We created 'Summary of findings' tables for our primary outcomes in assisted abstainers, following standard Cochrane methods, and used the five GRADE considerations (study limitations, consistency of effect, imprecision, indirectness, and publication bias) to assess the certainty of evidence for each outcome.

\section{RESULTS}

\section{Description of studies}

We identified 81 studies for inclusion (69,094 participants), five of which were new for this update. Details of the flow of studies are recorded in a PRISMA diagram in Figure 1. One paper reported two studies, each of which had multiple arms relevant to different comparisons (Buchkremer 1991 1; Buchkremer 1991 2), and six studies had subgroups or factorial designs that contributed to different sections or subgroups (Curry 1988; Killen 1990; Fortmann 1995; Schmitz 1999; Covey 2007; Croghan 2007). Most studies were conducted in the United States. Details of each included study can be found in the Characteristics of included studies table. 
Figure 1. Study flow diagram for current update

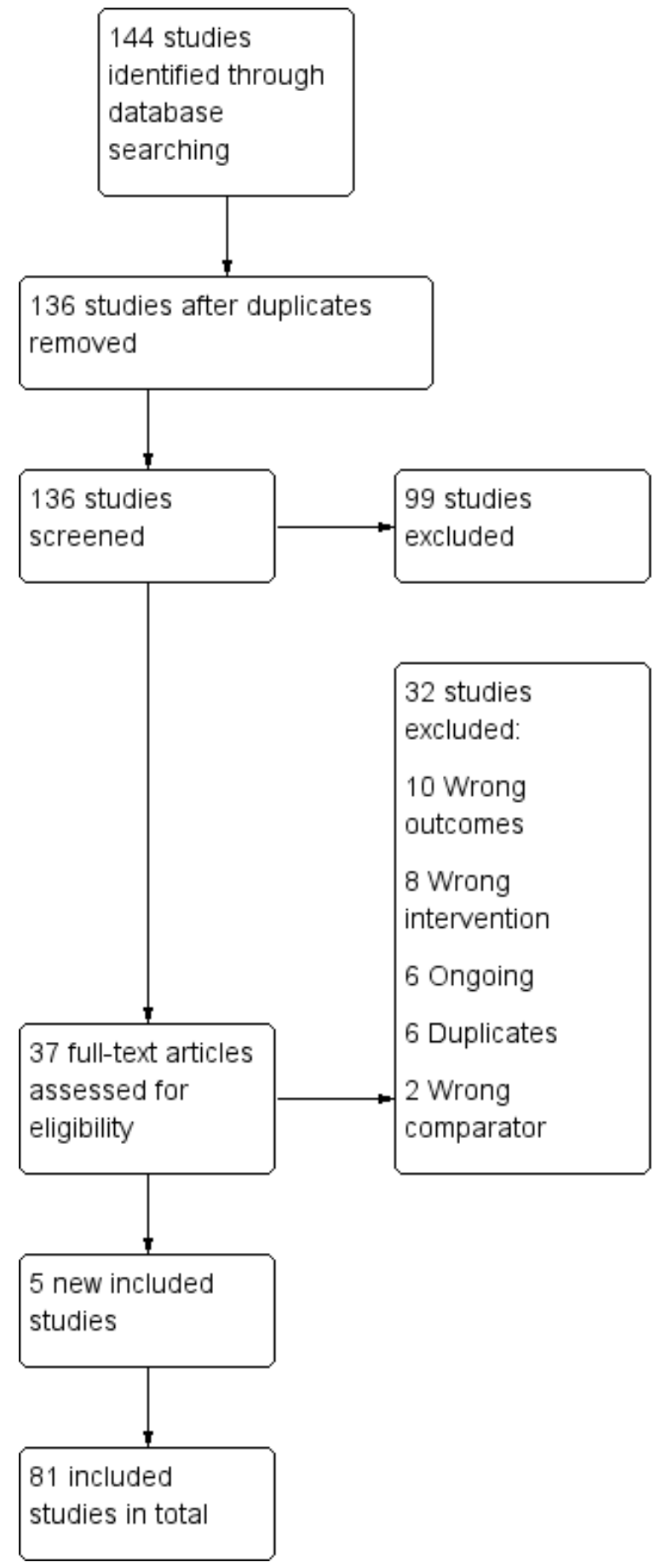

We described and analysed separately those studies that randomly assigned people who had already stopped smoking and those that randomly assigned people who were still smoking. We made two exceptions to this scheme: we considered Killen 2006 along with other extended pharmacotherapy trials, and we considered Wetter 2011 along with other studies testing behavioural adjuncts to cessation programmes.

Details of 57 excluded studies are listed in the Characteristics of excluded studies table. The main reasons for exclusion were follow-up of less than six months or not meeting our criteria for a study of relapse prevention. We excluded one previously included study (Schnoll 2015), because we removed the analysis of extended pharmacotherapy in smokers, as this is more extensively covered in reviews of individual pharmacotherapies (Hughes 2014; Cahill 2016; Lindson 2019). We identified 18 ongoing studies, details of which can be found in the Characteristics of ongoing studies table. 


\section{Section 1. Studies randomly assigning abstainers}

Fifty-one studies included people who had already stopped smoking.

We considered separately studies involving unaided abstainers who had stopped smoking where it was prohibited or discouraged for a set amount of time, due to factors such as pregnancy, hospital stay, or military training. Another group of studies concerned exsmokers recruited from the general population.

We divided studies into those assessing behavioural interventions and those assessing pharmacotherapy. We further divided the studies of general population abstainers into those that focused on unaided abstainers, and those that focused on aided abstainers. We classified behavioural interventions into intensive and less intensive categories. Intensive interventions involved repeated face-to-face contact, usually aimed at teaching clients to identify tempting situations and to apply a range of coping skills and cognitive strategies assumed to be of help in resisting relapse. Less intensive interventions usually attempted to teach these skills via written materials and could involve one brief face-toface session and telephone contacts. In the event that any studies used telephone contacts of sufficient frequency and duration to be considered an intensive intervention, we would have investigated the sensitivity of our findings to alternative categorisation.

\section{Interventions in special populations}

Twenty-eight studies focused on special populations such as pregnant and postpartum women, hospital inpatients and army recruits. Most used minimal face-to-face contact and relied primarily on written materials and/or phone calls. Studies examining more intensive interventions had very small sample sizes.

Eight studies among pregnant women (Severson 1997; McBride 1999; Hajek 2001; McBride 2004; Pbert 2004; Morasco 2006; Ruger 2008; Hannöver 2009) and one study in hospital inpatients (Schmitz 1999) included both current smokers and recent ex-smokers but analysed the two subgroups separately and so were eligible for inclusion here. Coleman-Cowger 2018 included current and recently-quit pregnant smokers but did not report outcomes separately for each group so we excluded this study from the metaanalysis. Two studies randomised smokers and recent ex-smokers during pregnancy and evaluated the effects of post-pregnancy interventions on women from both groups who did not smoke at delivery (McBride 1999; McBride 2004).

\section{Pregnant and postpartum ex-smokers}

Nineteen studies randomised pregnant (Ershoff 1995; SeckerWalker 1995; Lowe 1997; Secker-Walker 1998; McBride 1999; Hajek 2001; McBride 2004; Pbert 2004; Morasco 2006; Ruger 2008; Reitzel 2010; Brandon 2012; Levine 2016; Pollak 2016; Coleman-Cowger 2018) or postpartum (Severson 1997; Ratner 2000; Van't Hof 2000; Hannöver 2009) ex-smokers to interventions designed to assist them in remaining abstinent throughout their pregnancy and/or after delivery.

Six studies evaluated relatively brief interventions, comprising an initial face-to-face counselling session supported by written materials given out at the session (Secker-Walker 1995; Lowe 1997; Secker-Walker 1998; Hajek 2001), repeated mailings over a period of time (Ershoff 1995), or the addition of a video
(Severson 1997). In each case, there was provision for opportunistic support of different intensity at other routine visits. Van't Hof 2000 provided the initial relapse prevention counselling session and reinforcements at later visits without written pamphlets. Two studies included no face-to-face contact specific to the intervention but provided a series of phone calls (McBride 2004) or calls and letters, booklets, and newsletters (McBride 1999). Brandon 2012 provided no face-to-face contact, mailing a series of nine booklets over the course of the pregnancy and postpartum period. Morasco 2006 used a 90-minute psychotherapy session and additional phone calls. Hannöver 2009 and Ruger 2008 evaluated motivational interviewing, and Levine 2016 provided an enhanced cognitive behavioural intervention that began before delivery and continued through to 24 weeks postpartum. Ratner 2000 assessed a more intensive postpartum intervention that included a series of eight supportive telephone calls in addition to the initial session and written materials. Reitzel 2010 evaluated six telephone-based counselling sessions that included two calls postpartum and four calls up to sixteen weeks postpartum. This was a threearmed study, and participants in the second intervention arm were given two in-person counselling sessions, in addition to telephone counselling. The two intervention arms did not differ in outcomes, hence we combined them in our analysis. Pollak 2016 offered participants one in-person session during pregnancy and a series of phone calls lasting until nine months postpartum. The number of phone calls received depended on what their biobehavioural risk profile was judged to be. Coleman-Cowger 2018 evaluated 10 proactive phone calls given during pregnancy and continuing through six months postpartum. We excluded three studies from the meta-analysis. Pbert 2004 randomly assigned clinics to implement a provider counselling and office systems intervention. We were unable to extract data from this study in a comparable format to pool with the other studies, so we reported it separately. Unlike the other studies, Levine 2016 matched contact between the two intervention groups, so the study was not included in the meta-analysis. Coleman-Cowger 2018 did not report separate outcomes for current and recently-quit smokers so could not be included in the meta-analysis.

\section{Hospital inpatients}

Six studies randomised hospital inpatients who were abstinent whilst admitted to interventions to help them stay abstinent postdischarge. Two studies evaluated pharmacotherapy in conjunction with behavioural support. Cummins 2016 randomised hospitalised smokers undergoing enforced abstinence to receive either telephone counselling, NRT, or both, compared with a usual care control, and Brandstein 2012 gave participants eight weeks of NRT and telephone counselling post-discharge. The remaining studies tested solely behavioural interventions. Two studies randomised hospital inpatients diagnosed with cardiovascular illness who had not smoked from the time of hospital admission. Hajek 2002 evaluated a brief, routine, one-off intervention supported by written materials, and Schmitz 1999 compared six weekly sessions of skills-oriented relapse prevention with didactic presentations. Hasuo 2004 randomly assigned participants who had quit during or shortly before hospitalisation to receive three telephone calls after discharge; all participants received counselling in hospital. Campos 2018 gave inpatients either a 40-minute counselling session (with relapse prevention component) or 10-minute counselling session (purely educational about the dangers of smoking). 


\section{Military recruits}

Three studies provided interventions to smokers undergoing enforced abstinence during armed forces training. Two randomly assigned United States Air Force recruits: Klesges 1999 provided a 50-minute session during training that covered the short-term health consequences, costs and social impact of smoking, and Klesges 2006 provided two one-hour sessions. Conway 2004 randomly assigned naval recruits; in addition to regular smokers, the intervention targeted former, occasional, and experimental smokers. Two interventions were tested: (1) written materials mailed in six instalments after the conclusion of training, and (2) access to a telephone help line.

\section{Behavioural interventions in unselected populations}

Sixteen studies explored behavioural interventions in general populations of abstainers.

\section{Behavioural interventions for unaided abstainers}

Five studies randomly assigned participants recruited from local communities.

- In Killen 1990, volunteers recruited by advertisements were encouraged over the phone to set a quit date and were randomly assigned if they managed to abstain for 48 hours.

- In Fortmann 1995, volunteers recruited with the help of random digit dialling and incentives were randomly assigned following a 24-hour abstinence.

- Brandon 2000 and Brandon 2004 recruited volunteers who reported at least one week of abstinence (the average duration of prior abstinence was 16 months in Brandon 2000 and 75 days in Brandon 2004).

- In Borland 2004, callers to a quitline were recruited into a study a day or two later, and we included only the subgroup of callers who had already quit at this baseline.

All interventions were of relatively low intensity, involving self-help materials or telephone contact.

- Killen 1990 examined effects of an eight-week self-guided relapse prevention programme based on 16 modules. Participants received the basic module at the first session. After this, another seven modules, either selected by participants or assigned randomly, were dispensed via weekly mailings over the next seven weeks. The factorial study also included nicotine chewing gum conditions (covered later).

- Fortmann 1995 evaluated a two-phase self-help relapse prevention programme that included 12 weekly progress reports to be mailed by participants to the programme office. The factorial study also included nicotine chewing gum conditions (covered later).

- Brandon 2000 compared effects of a single booklet with effects of a partially proactive telephone helpline, eight booklet mailings, and a combination of helpline and mailings.

- Borland 2004 compared the provision of tailored advice letters based on telephone assessments with the provision of standard materials only.

- Brandon 2004 manipulated contact and content by comparing eight booklet mailings over 12 months, the same booklets at a single mailing, eight supportive letters over 12 months, and a single booklet which we treated as the control in the analysis.

\section{Behavioural interventions for assisted abstainers}

Twelve studies randomly assigned abstaining smokers who had taken part in a formal treatment programme. We judged five study interventions to be of higher intensity (Powell 1981; Stevens 1989; Razavi 1999; Smith 2001; Mayer 2010), and the rest to be of lower intensity.

- Powell 1981 randomly assigned abstainers at the end of a fiveday programme to a four-week support group, a telephone 'buddy' system, or a no-treatment control.

- Stevens 1989 recruited smokers who had a quit date one week earlier and were smoking no more than one cigarette in the previous four days. Participants were randomly assigned to three weekly skills-training group sessions, three weekly discussion group sessions, or a no-treatment control.

- Razavi 1999 randomly assigned clients abstinent at the end of a three-month treatment with nicotine patch and group support to monthly group meetings focusing on relapse prevention strategies, monthly group meetings run by former smokers offering general support, or to a no-treatment control.

- Smith 2001 randomly assigned participants eight days after quit date, using stratification based on smoking status, so that those who were abstinent during this week were analysed separately. The two intensive interventions consisted of six 90-minute group sessions spaced over four weeks after the randomisation session. They focused on developing cessation skills and negative affect (cognitive-behavioural treatment) or on fostering intrinsic motivation and resolving participant ambivalence (motivational interviewing). The control group did not receive any intervention after the randomisation session.

- Mermelstein 2003 randomly assigned people at the end of a seven-week group behavioural programme to receive tailored counselling calls or non-specific calls from their counsellor. We included only the subgroup of participants who were abstinent at the end of the group meeting.

- Mayer 2010 studied participants in workplace cessation programmes. At the end of the programme, abstinent participants were randomly assigned to ten sessions of workplace group counselling or ten sessions of proactive telephone counselling over the course of nine months. This study did not include a control group; therefore it was not included in the meta-analysis. Results are reported narratively later.

- McNaughton 2013 randomised participants who had quit following a 12-week course of varenicline and interactive voice response calls to receive additional biweekly calls from weeks 13 to 52 , compared with no further calls.

- Blyth 2015 randomised participants who had successfully quit for four weeks using the NHS Stop Smoking service to receive a set of eight revised Forever Free booklets targeted at relapse prevention, compared with a single 'Learning to Stay Stopped' booklet.

- Cheung 2015 randomised participants who had successfully quit for seven days using a combination of pharmacotherapy and behavioural support to receive one of two social media interventions lasting two months compared with usual care.

- McDaniel 2015 randomised Quit for Life or employer healthplan enrollees who had quit for 24 hours or more to receive either 10 or 20 interactive voice response (IVR) delivered relapse risk assessments, which triggered a transfer to a Quit Coach 
for participants exceeding a risk threshold, compared with a standard treatment control.

- Hayes 2018 provided participants who had quit for 24 hours using a state quitline with a print-based self-administered six-month parenting program designed to engage parents of school-aged children in antismoking socialisation.

- Veldheer 2018 assigned participants who had quit following six weekly group support sessions to receive either eight self-directed relapse prevention materials or one information booklet on cigarettes.

\section{Pharmacological interventions}

\section{Pharmacological interventions for short-term unaided abstainers}

Two studies of nicotine gum randomly assigned participants who had briefly stopped unaided.

- Killen 1990 randomly assigned participants who stopped unaided for 48 hours to nicotine gum on a fixed or ad lib dosing schedule and included a no-gum control.

- Fortmann 1995 randomly assigned participants who stopped smoking unaided for 24 hours to nicotine chewing gum and no medication groups. Both of these factorial studies also included behavioural interventions, as discussed above.

\section{Pharmacological interventions for abstainers following cessation pharmacotherapy}

Eight studies enrolled people to use pharmacotherapy to aid initial cessation before randomly assigning successful abstainers to pharmacotherapy for maintenance. We also included in this subgroup a ninth study, Killen 2006, in which participants were randomly assigned before starting the quit attempt. The classification of this study is discussed further in Effects of interventions. Six studies evaluated the effects of extended treatment with bupropion. Three of them also included arms that used nicotine replacement therapy (NRT). Two studies evaluated the effects of extended use of varenicline and one study evaluated the effects of extended use of rimonabant.

- Hays 2001 used bupropion to aid cessation, and participants were randomly assigned if they had quit for at least one week at the end of seven weeks of treatment. Bupropion or placebo was used for the rest of the year, and participants were followed up for a second year.

- Hurt 2003 used a nicotine patch to aid cessation, and abstainers were eligible for randomisation at the end of eight weeks of patch therapy. Bupropion or placebo was used for six months after randomisation and participants were followed up for another six months.

- Killen 2006 used combination therapy of nicotine patch, bupropion, and individual relapse prevention counselling for almost three months, then either bupropion or placebo (after tapering of bupropion) for 14 weeks. Follow-up was at 12 months from quit date. Because participants were randomly assigned at baseline, people who had failed to quit were still eligible for the randomised phase and were included in the denominator.

- STRATUS-WW 2006 randomly assigned participants to $5 \mathrm{mg}$ or $20 \mathrm{mg}$ rimonabant for 10 weeks. In the second phase, abstainers in the $5 \mathrm{mg}$ group were randomly assigned to a further 42 weeks of $5 \mathrm{mg}$ rimonabant or placebo, and abstainers in the $20 \mathrm{mg}$ group were randomly assigned to a further 42 weeks of $5 \mathrm{mg}$ of rimonabant, $20 \mathrm{mg}$ of rimonabant or placebo. Participants were followed up at the end of treatment (52 weeks from baseline).

- Tonstad 2006 used open-label varenicline for 12 weeks. Abstainers were randomly assigned to varenicline or placebo for a further 12 weeks, and then were followed up for six months for assessment of abstinence 12 months from quit date.

- Covey 2007 used a bupropion and nicotine patch combination to aid cessation and randomly assigned abstainers after eight weeks. The double-blind placebo-controlled maintenance phase tested bupropion and nicotine gum in a factorial design. Therapy lasted 16 weeks, and participants were followed up for another six months to assess abstinence 12 months from quit date.

- Croghan 2007 randomly assigned participants to bupropion, nicotine inhaler, or combination therapy for three months. In a second phase, abstainers using a single therapy were randomly assigned to continue the same therapy or receive a placebo for a further nine months, with post-therapy follow-up for a further three months. Abstainers using combination therapy were randomly assigned factorially to bupropion or placebo pill and nicotine inhaler or placebo inhaler.

- Hays 2009 used weekly counselling and nicotine patches to aid cessation in a group of recovering alcoholics. At the end of eight weeks of treatment, participants who had quit for at least the last week of patch therapy were randomly assigned to either bupropion or placebo for 44 weeks.

- Evins 2014 enrolled community mental health centre outpatients diagnosed with schizophrenia or bipolar disease who had successfully quit for two weeks with 12 weeks of varenicline and cognitive behavioural therapy (CBT). Participants received 40 weeks of maintenance varenicline and a tapering schedule of relapse prevention-focused CBT.

\section{Section 2. Studies randomly assigning smokers before their quit date}

All studies in this section assessed behavioural interventions. We included two categories of behavioural studies: those that compared time-matched interventions with and without the relapse prevention elements, and those that looked at the effect of extended participant contact. For studies with more than two arms, we included the most intensive versus the least intensive in the main meta-analysis, and we discussed additional differences in the results. We referred to the least intensive intervention as the 'control'.

To evaluate the impact of treatment intensity, we considered separately interventions providing treatment for up to four weeks and interventions providing participant contact for longer than four weeks.

\section{Intervention and control groups matched for contact time}

In ten studies, intervention and control conditions were matched for the amount of contact (some studies also compared a longer intervention, in which case the relevant arms were compared in the next category). Eight used a group format for behavioural intervention (Hall 1984; Davis 1986; Curry 1988; Emmons 1988; Buchkremer 1991 1; Buchkremer 1991 2; Becona 1997; Schroter 2006) and two used an individual counselling format (Niaura 1999; Schmitz 1999). Three provided pharmacotherapy in all treatment 
conditions (Emmons 1988; Buchkremer 1991 1; Buchkremer 1991 2). In one study, a factorial design was used to test nicotine gum against no gum (Niaura 1999).

The components used for relapse prevention were varied.

- Hall 1984 was a factorial study. The arms comparing two variants of aversive smoking were combined in this analysis. In six of the 14 sessions, the relapse prevention (RP) group received relaxation and relapse prevention skills training and reviewed the cost of smoking and the benefits of abstinence, while the control group met for general discussion.

- Davis 1986 compared three six-session treatments (i.e. active skills training, discussion of high-risk situations (not shown in graphs), and a standard programme). Only 45 participants were included in the study.

- In one arm of a factorial study, Curry 1988 compared two programmes in a self-help format: one using a skills-oriented relapse prevention training permissive to slips, and the other stressing absolute abstinence. The other arm compared these two approaches delivered in a format of eight weekly group sessions, where the absolute abstinence approach also included gradual reduction and a quit date two weeks later than in the relapse prevention group. The two study arms were treated separately.

- Emmons 1988 compared two programmes with different numbers of sessions across the same period of time, both accompanied by nicotine gum. The relapse prevention programme consisted of eight weekly sessions focused on coping with high-risk situations, cognitive behavioural strategies, and role-play. The 'Broad Spectrum' behavioural programme consisted of 12 sessions that focused on strategies for dealing with cravings and weight control, with quitting preceded by nicotine fading over three weeks.

- Two studies by Buchkremer and colleagues explored a variety of behavioural components, as well as different dosing schedules, for the nicotine patch. The programme consisted of nine weekly sessions with a target quit date after six weeks of gradual reduction. Relapse prevention components including role-play were included in one intervention, and this was compared with a control of the same length (Buchkremer 1991 1). In a second study, an alternative relapse prevention approach was used; the programme was modified to reach total abstinence after four weeks, and behaviour therapy techniques such as covert sensitisation and thought-stopping were added. As the differences were relatively small, we combined the two relapse prevention programmes (Buchkremer 19912 ).

- Becona 1997 compared eight-week behavioural treatment programmes with and without a relapse prevention problemsolving component.

- Niaura 1999 tested imaginary cue exposure as an addition to individual cognitive behavioural treatment. All groups had five post-quit sessions, and we have included them in the matched contact control group, although the duration of both control conditions was different. In a factorial design, a nicotine gum condition and a no-gum condition were compared.

- Schmitz 1999 used a sample of women with cardiac risk and compared six sessions of skills-oriented relapse prevention with six sessions of didactic presentations on cardiac risk and the benefits of quitting.
- Schroter 2006 compared six sessions that included components such as role-playing, coping responses to high-risk situations, and self-awareness with a standard behavioural cessation programme that focused on positive changes attained through abstinence.

\section{Intervention and control arms not matched for contact time or duration}

Almost all smoking cessation studies that compared more and less intensive treatments included some intervention to prevent relapse. We included only studies that specified relapse prevention as an explicit focus of the intervention in the title or abstract. We did not include studies that offered treatment proactively to special populations such as pregnant or hospitalised smokers because all studies using these groups provided some relapse prevention input within the active treatment arm, and they were covered in separate meta-analyses. When studies had three or more treatment conditions, the main analyses compared the most and least intensive interventions.

\section{Behavioural interventions}

\section{Varying intensity of face-to-face treatment}

Seven studies compared longer and shorter programmes. The relative intensity of the common cessation programme and of the additional relapse prevention component was variable. We subgrouped studies according to whether the control group received more than four sessions.

- Killen 1984 provided nicotine gum and one-week intensive behavioural treatment, which included relapse prevention components plus seven further brief visits, and compared groups with and without two additional group sessions and optional drop-in visits. A group with no gum was also included but was not used in our analysis.

- Brandon 1987 treated a sample of smokers in six sessions over two weeks and compared a group receiving no further treatment with a group receiving four additional relapse prevention sessions. Another arm with a rapid puffing component was not covered in this review.

- Hall 1987 combined nicotine or placebo gum with five or 14 sessions, and the more intensive treatment also contained a larger relapse prevention component.

- Buchkremer 19911 tested the addition of three booster sessions six months after the basic nine-session programme and a programme with relapse prevention components. All groups received nicotine patches.

- Shoptaw 2002 studied smokers treated for heroin dependence and compared the nicotine patch combined with 12 weeks of brief visits with the additions of a behavioural programme that included relapse prevention and mood management, a contingency management programme in which participants were paid for abstinence, and a combination of the latter two.

In two studies, control groups were offered four or fewer sessions.

- Hall 1985 combined nicotine gum with four educational sessions over three weeks or a behavioural treatment that included relapse prevention components provided in 14 sessions over eight weeks (a behavioural treatment-only group was not included here). 
- Lifrak 1997 combined nicotine patch treatment with three supportive sessions with a nurse over nine weeks or with 16 relapse prevention sessions with a behavioural therapist over 16 weeks.

\section{Extended contact using proactive phone calls}

Three studies tested extended contact via proactive phone calls. Lando 1996 provided group-based behavioural therapy for eight weeks and compared a group receiving no further treatment with a group receiving proactive calls 1,8 , and 11 months later. Segan 2011 randomly assigned callers to the Victoria, Australia, quitline to four to six additional calls explicitly designed to prevent smoking relapse and compared this with a control group with no additional calls. Blebil 2014 recruited people attending stopsmoking clinics. Both groups received a series of calls following smoking clinic visits over three months, with the intervention group receiving additional phone calls. We excluded other studies that tested the use of telephone counselling as an adjunct (add-on) to nicotine replacement therapy because they did not describe the intervention as relapse prevention, and most of the behavioural support was provided during the period of intended pharmacotherapy (i.e. not extending the overall duration of treatment).

\section{Additional print-based support}

Unrod 2016 randomised quitline callers to receive eight Forever Free relapse prevention booklets either all at once or over a 12 month period, compared with usual care. In Sheffer 2010, quitline callers were randomly assigned to standard quitline service or to standard quitline service plus eight printed self-help booklets aimed at relapse prevention. This was a quasi-randomised trial with significant baseline imbalances. Simmons 2018 randomised participants to either receive intensive repeated mailings (10 booklets over 18 months), standard repeated mailings (eight booklets over 12 months) or one traditional self-help booklet. Both the intensive mailings and standard mailings used self-help materials with a relapse prevention component, and we compared each with the self-help control separately in the meta-analysis, with the control group split between the two comparisons.

\section{Additional intervention delivered by computer or mobile phone}

Four studies tested additional support provided by computer or mobile phone. Japuntich 2006 provided bupropion and brief individual counselling to all participants. The intervention consisted of internet access to the Comprehensive Health
Enhancement Support System for Smoking Cessation and Relapse Prevention (CHESS SCRP) for 12 weeks. Wetter 2011 tested the addition of computer-delivered treatment. All participants were provided with six weeks of nicotine patch therapy, five group counselling sessions, and ecological momentary assessment (EMA) procedures for one month post-quit date. In addition to the EMA, the intervention arm received computer-delivered treatment on palmtop computers for one month post-quit date, consisting of three modules. Hicks 2017 recruited adult smokers with posttraumatic stress disorder (PTSD). All participants received a mobile phone with a preinstalled contingency management app. The intervention group also received a Stay Quit Coach app tailored for the specific needs of patients with chronic PTSD and designed to be integrated into ongoing psychotherapy. Durmaz 2019 sent participants in the intervention group 60 WhatsApp messages which provided informative support leading up to and following the quit date, with a focus on preventing relapse. However, participants in the control group received relapse prevention support as part of the usual care common to both groups.

\section{Formulation of coping strategies}

Van Osch 2008 provided participants in a national Quit and Win contest with computer-tailored cessation advice and telephone counselling for one month post-quit date. The intervention and control arms received the exact same programme, but in the intervention arm, participants were asked to formulate three coping plans when completing the baseline survey.

\section{Combined behavioural and pharmacological interventions}

Joseph 2011 tested extended treatment with counselling and NRT. All participants were provided with NRT and five telephone calls over four weeks. In the intervention arm, participants received extended telephone counselling and NRT for a further 48 weeks. The control arm received one additional call at eight weeks and no additional NRT.

\section{Risk of bias in included studies}

Risk of bias assessments are summarised in Figure 2 and Figure 3. Judgements were summarised by the domains below. We judged 22 studies to be at high risk of bias in one or more domains, 53 to be at unclear risk of bias in one or more domains and not high in any domain, and six studies to be at low risk of bias across all domains. Details on 'Risk of bias' judgements for each study can be found in Characteristics of included studies. 


\section{Figure 2.}

Random sequence generation (selection bias)

Allocation concealment (selection bias)

Blinding of participants and personnel (performance bias)

Blinding of outcome assessment (detection bias)

Incomplete outcome data (attrition bias)

Other bias
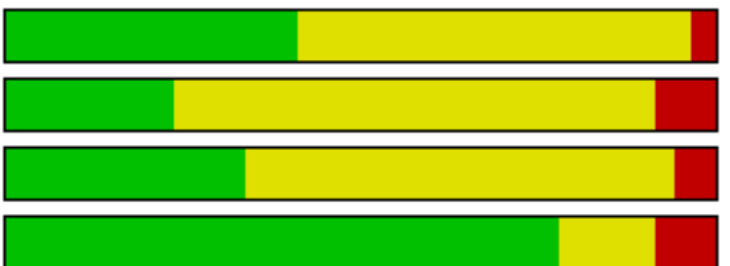

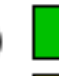

\begin{tabular}{|c|c|c|}
\hline $0 \%$ & $25 \%$ & $50 \%$ \\
\hline
\end{tabular}


Figure 3. Risk of bias summary: review authors' judgements about each risk of bias item for each included study.

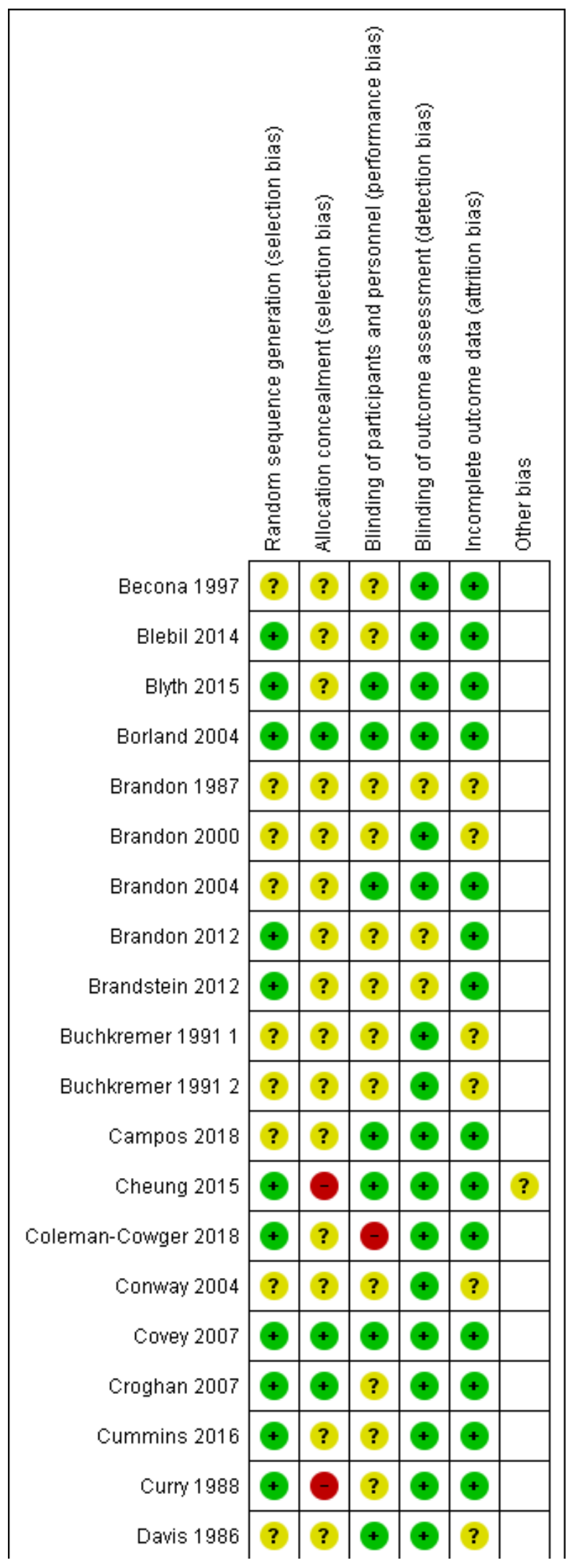


Figure 3. (Continued)

\begin{tabular}{|c|c|c|c|c|c|c|}
\hline Davis 1986 & $?$ & $?$ & $\odot$ & $\odot$ & $?$ & \\
\hline Durmaz 2019 & $\odot$ & $\odot$ & + & 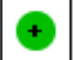 & + & \\
\hline Emmons 1988 & $?$ & $?$ & + & + & $?$ & \\
\hline Ershoff 1995 & $?$ & $\odot$ & 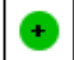 & 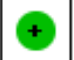 & + & \\
\hline Evins 2014 & + & $\odot$ & + & + & $\odot$ & \\
\hline Fortmann 1995 & $?$ & $?$ & $?$ & + & $\odot$ & \\
\hline Hajek 2001 & $\odot$ & $\Theta$ & $?$ & $\odot$ & $\odot$ & \\
\hline Hajek 2002 & $?$ & $\odot$ & $?$ & + & + & \\
\hline Hall 1984 & $?$ & $?$ & $?$ & + & + & \\
\hline Hall 1985 & $?$ & $?$ & - & 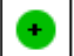 & $\odot$ & \\
\hline Hall 1987 & $?$ & $?$ & $?$ & + & + & \\
\hline Hannöver 2009 & $\odot$ & $\odot$ & $?$ & - & $?$ & \\
\hline Hasuo 2004 & $\oplus$ & $\odot$ & + & $?$ & + & \\
\hline Hayes 2018 & $?$ & $?$ & $?$ & + & $\odot$ & \\
\hline Hays 2001 & $\odot$ & $\odot$ & + & + & + & \\
\hline Hays 2009 & $?$ & $?$ & $?$ & + & + & $?$ \\
\hline Hicks 2017 & $\odot$ & $?$ & $?$ & + & $\Theta$ & \\
\hline Hurt 2003 & $?$ & $?$ & $?$ & + & $?$ & \\
\hline Japuntich 2006 & $?$ & $?$ & 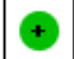 & $\odot$ & $\odot$ & \\
\hline Joseph 2011 & $\odot$ & + & $?$ & 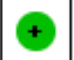 & + & \\
\hline Killen 1984 & $?$ & $?$ & O & + & $?$ & \\
\hline Killen 1990 & $?$ & $?$ & $?$ & + & $?$ & \\
\hline Killen 2006 & + & $\odot$ & + & 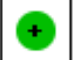 & + & \\
\hline Klesges 1999 & $?$ & $\odot$ & $?$ & $\odot$ & + & \\
\hline Klesges 2006 & $?$ & $\odot$ & $?$ & 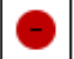 & $?$ & \\
\hline Lando 1996 & $?$ & $?$ & $?$ & + & + & \\
\hline Levine 2016 & $\oplus$ & $?$ & + & + & + & \\
\hline Lifrak 1997 & $?$ & $?$ & $?$ & $O$ & + & \\
\hline Lowe 1997 & $?$ & $?$ & + & $?$ & + & $?$ \\
\hline Mayer 2010 & + & $?$ & $?$ & + & + & $\odot$ \\
\hline McBride 1999 & $?$ & $?$ & + & + & + & \\
\hline
\end{tabular}


Figure 3. (Continued)

\begin{tabular}{|c|c|c|c|c|c|c|}
\hline McBride 1999 & $?$ & $?$ & $\oplus$ & $\odot$ & $\odot$ & \\
\hline McBride 2004 & $?$ & $?$ & $?$ & $?$ & $?$ & \\
\hline McDaniel 2015 & $\odot$ & $\odot$ & $?$ & $\odot$ & $\odot$ & \\
\hline McNaughton 2013 & + & $?$ & $?$ & $\odot$ & $\odot$ & \\
\hline Mermelstein 2003 & $?$ & $?$ & 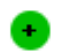 & $\odot$ & $\odot$ & \\
\hline Morasco 2006 & $?$ & $?$ & $?$ & $\odot$ & $?$ & \\
\hline Niaura 1999 & $?$ & $?$ & $?$ & $\odot$ & $?$ & \\
\hline Pbert 2004 & $?$ & - & $?$ & + & + & \\
\hline Pollak 2016 & 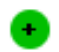 & $?$ & $?$ & $\odot$ & $?$ & \\
\hline Powell 1981 & $?$ & $?$ & $\odot$ & $\odot$ & $\odot$ & \\
\hline Ratner 2000 & 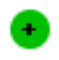 & $?$ & $?$ & $\odot$ & $\oplus$ & \\
\hline Razavi 1999 & + & $\odot$ & + & $\odot$ & $?$ & \\
\hline Reitzel 2010 & + & + & $\odot$ & + & + & \\
\hline Ruger 2008 & $?$ & $\odot$ & $?$ & $?$ & $?$ & \\
\hline Schmitz 1999 & $?$ & $?$ & $?$ & $?$ & + & \\
\hline Schroter 2006 & $?$ & $?$ & $?$ & $\odot$ & $\odot$ & \\
\hline Secker-Walker 1995 & $?$ & $?$ & $?$ & $?$ & $?$ & \\
\hline Secker-Walker 1998 & $?$ & $?$ & $?$ & $\odot$ & $\odot$ & \\
\hline Segan 2011 & $\odot$ & $\odot$ & $\odot$ & $\odot$ & $\odot$ & $\odot$ \\
\hline Severson 1997 & $?$ & $?$ & $?$ & $\odot$ & $\odot$ & \\
\hline Sheffer 2010 & $\odot$ & $\odot$ & $\oplus$ & $\odot$ & $\odot$ & \\
\hline Shoptaw 2002 & + & + & $?$ & + & + & \\
\hline Simmons 2018 & ? & $?$ & $\odot$ & $\odot$ & $?$ & \\
\hline Smith 2001 & $?$ & $?$ & $?$ & $?$ & $?$ & \\
\hline Stevens 1989 & + & $?$ & $?$ & $\odot$ & $\odot$ & \\
\hline STRATUS-WM 2006 & $?$ & $?$ & $?$ & $?$ & $?$ & \\
\hline Tonstad 2006 & + & $\odot$ & + & + & $\odot$ & \\
\hline Unrod 2016 & + & $?$ & + & - & + & \\
\hline Vant Hof 2000 & $?$ & $?$ & $?$ & $\odot$ & $\odot$ & \\
\hline Van Osch 2008 & - & $?$ & + & + & - & \\
\hline Veldheer 2018 & $?$ & $?$ & + & $\odot$ & $\odot$ & \\
\hline Wetter 2011 & + & $?$ & $?$ & + & + & \\
\hline
\end{tabular}




\section{Sample size}

Many studies were small and therefore had limited power to detect realistic differences in quit rates, especially in the group that randomly assigned smokers before the quit date.

\section{Study design}

Studies randomly assigning successful end-of-treatment quitters provide the most straightforward test of relapse prevention interventions designed for clinical practice (see Discussion). Eight studies of pharmacological treatments used this approach, but only six studies of behavioural treatments randomly assigned participants who were abstinent after more than one week of treatment (Razavi 1999; Mermelstein 2003; Mayer 2010; McNaughton 2013; Blyth 2015; Cheung 2015).

\section{Definition of smoking cessation}

All studies were required by our inclusion criteria to report smoking status a minimum of six months from the start of the intervention. In the case of studies that randomly assigned smokers before quitting, this could have been from the quit date. Some studies timed follow-up from the end of treatment. Fifteen studies had six months' follow-up (Emmons 1988; Schmitz 1999; Van't Hof 2000; Japuntich 2006; Reitzel 2010; Sheffer 2010; Brandstein 2012; Blebil 2014; Cheung 2015; Cummins 2016; Hicks 2017; Campos 2018; Coleman-Cowger 2018; Veldheer 2018; Durmaz 2019), and all others had a longer follow-up period from the start of intervention. Some studies did not provide a definition of abstinence (Powell 1981; Becona 1997; Klesges 1999; Hasuo 2004; Campos 2018), and most others reported a point prevalence rather than a sustained measure of abstinence.

\section{Allocation}

Thirty-three studies adequately reported their method of randomisation and we judged them to be at low risk of bias. Fortysix studies did not adequately report on randomisation and we judged them at unclear risk. We judged three studies to be at high risk of bias. Van Osch 2008 assigned participants based on odd or even registration numbers. Hannöver 2009 based allocation on alternation of study screening forms. Sheffer 2010 assigned all callers to a quitline within a six-week period to the intervention group and callers during the six weeks preceding and following the given six-week period to the control group.

As well as judging the randomisation of studies, we also evaluated the concealment of that randomisation. We judged 19 studies to be at low risk of bias. Seven studies did not conceal allocation and thus were at high risk of selection bias. The remaining studies did not adequately describe allocation concealment; we judged the risk of bias for these studies as unclear.

In total, eight studies were at high risk for some kind of selection bias, and 15 studies were at low risk for selection bias from both sources. The remaining studies were at unclear risk of bias from either randomisation or concealment.

\section{Blinding (performance bias)}

Most studies did not provide sufficient detail to allow evaluation of risk of performance bias and hence were judged to be at unclear risk in this domain. Twenty-seven studies provided details of blinding procedures sufficient to rate them at low risk of bias in this domain (or, in the case of behavioural interventions where blinding of participants was not possible, where other study characteristics such as similar amounts of contact between conditions, or participants not knowing about other conditions, meant that performance bias was judged to be unlikely). We judged five studies to be at high risk of performance bias: two studies testing NRT did not provide placebo to the control arms (Killen 1984; Hall 1985); in one study of a behavioural intervention, neither participants nor providers were blinded, and control participants were aware that the intervention arm was receiving additional treatment (Reitzel 2010); in Segan 2011 blinding was broken; and in Coleman-Cowger 2018 blinding was not possible and there was a substantial difference in contact levels between the intervention and control groups.

\section{Validation of self-reported abstinence (detection bias)}

Biochemical validation of most or all self-reports of abstinence was reported for most studies. Sixteen studies did not attempt any validation (Powell 1981; Severson 1997; Klesges 1999; Van't Hof 2000; Mermelstein 2003; Borland 2004; Conway 2004; Klesges 2006; Schroter 2006; Van Osch 2008; Hannöver 2009; Sheffer 2010; Joseph 2011; Segan 2011; Simmons 2018; Durmaz 2019), but in some other cases, samples were not collected from all participants, were not collected at long-term follow-up, or were not used to correct selfreports. In one unpublished study, it was unclear whether results were validated (STRATUS-WW 2006), and Ruger 2008 reported the use of biochemical validation but not the cut-off value or the level of misreport. Pbert 2004 noted greater deception amongst intervention group participants than amongst those in the control condition. Brandon 2012 only performed biochemical validation of abstinence in participants within 100 miles of the research team.

In studies of behavioural smoking cessation interventions, lack of biochemical validation of self-reported smoking status risks the introduction of significant bias. Participants who received more intensive care can be expected to be trying harder to please their advisors and report 'good news'. When the intervention group received more face-to-face contact than the control group and the results were not biochemically validated, we judged studies to be at high risk of detection bias.

Overall, we judged seven studies to be at high risk of detection bias because of lack of verification of results. Eleven studies did not provide sufficient information; we judged these to be at unclear risk. The remaining studies were all at low risk of detection bias.

\section{Incomplete outcome data}

Another risk of bias specific to smoking cessation studies concerns excluding participants lost to follow-up from the analysis or imputing their outcomes as if their loss to follow-up was independent of outcome. This is because in smoking cessation treatments, participants who fail in stopping smoking may feel embarrassed and may find further participation unhelpful, while those who are successful may be more likely to stay in touch. Treating those lost to follow-up as still smoking is likely to be a reasonable assumption, but sometimes the actual figures were not available, or loss to follow-up was such that most participants did not provide data, or many more participants had been followed up in one arm than in another. When these limitations were present, studies were judged to be at unclear or high risk of attrition bias. 
Most studies reported low or moderate losses to follow-up in sufficient detail to be judged at low risk of bias in this domain. Three studies were at high risk from attrition bias. In Evins 2014 there was a $55 \%$ follow-up rate in the control group compared with $88 \%$ in the intervention group. In Hicks 2017 there was a 50\% follow-up rate in the control group compared with $80 \%$ in the intervention group. In Van Osch 2008, loss to follow-up was high in both arms (less than $40 \%$ of participants followed up at seven months); the study authors cautioned that this limited the validity of the results. A further 22 studies were judged to be at unclear risk of bias in this domain, as the studies did not report results in sufficient detail to permit counting of all participants lost to follow-up as continuing smokers in our analyses.

\section{Other potential sources of bias}

We judged two studies to be at high risk of bias from other sources (Mayer 2010; Segan 2011). Mayer 2010 reported a higher initial abstinence in one study arm, and in Segan 2011 there was probable contamination of study arms. We judged three studies to be at unclear risk from other sources (Lowe 1997; Hays 2009; Cheung 2015). Lowe 1997 had potential contamination of study arms. In Hays 2009 there was a discrepancy in reported results data. In Cheung 2015 it was unclear whether results had been adjusted for cluster randomisation. We did not detect any other sources of potential bias in the remaining studies.

\section{Effects of interventions}

See: Summary of findings for the main comparison Behavioural interventions for assisted abstainers; Summary of findings 2 Pharmacotherapy for assisted abstainers

\section{Section 1. Studies of abstainers}

\section{Behavioural interventions in special populations}

\section{Pregnant and postpartum ex-smokers}

Pooled results from eight studies of interventions in pregnancy did not demonstrate a benefit at the end of pregnancy $(n=1523$, risk ratio $[R R] 1.05,95 \%$ confidence interval $[\mathrm{Cl}] 0.99$ to 1.11 , $1^{2}=0 \%$; Analysis 1.1). Fifteen studies included follow-up during the postpartum period. We also detected no significant benefit among this group of studies, overall or in subgroups, according to timing of intervention, with the confidence interval narrowly missing significance $(n=4606, \operatorname{RR} 1.02,95 \% \mathrm{Cl} 0.94$ to $1.09,12=$ $3 \%$; Analysis 1.2). There were two studies that we could not include in the meta-analysis. We were unable to extract data from Pbert 2004 in a comparable format to pool with the other studies, but it did not detect any significant effect of intervention on spontaneous quitters at delivery; the postpartum non-smoking rate was higher in the usual care group. Unlike the other studies, Levine 2016 matched contact between the two intervention groups, so the study was not included in the meta-analysis. However, it did not detect an effect in favour of either group ( $\mathrm{n}=300, \mathrm{RR} 0.80,95 \% \mathrm{Cl} 0.53$ to 1.20 ).

\section{Hospital inpatients}

There was no evidence of a benefit of behavioural intervention in hospitalised patients who had not smoked in hospital, based on pooled results from four studies (Schmitz 1999; Hajek 2002; Hasuo 2004; Campos 2018), and the behavioural arm of Cummins $2016(\mathrm{n}=1385$, RR $1.10,95 \% \mathrm{Cl} 0.82$ to $1.47, \mathrm{l}=58 \%$; Analysis 2.1). Pharmacological interventions were not found to be beneficial either, based on pooled results of nicotine replacement therapy (NRT) from Brandstein 2012, and two arms from Cummins 2016, one of NRT, and one of NRT plus telephone counselling ( $n=1078$, RR $1.23,95 \% \mathrm{Cl} 0.94$ to $1.60, \mathrm{I}^{2}=0 \%$; Analysis 2.2 ).

\section{Military recruits}

We did not display results graphically or pool results because denominators were unclear and reported results were corrected for clustering. In all three studies, the period of enforced abstinence did give rise to a higher quit rate than the spontaneous rate expected in these populations of young smokers, but only Klesges 2006 reported a statistically significant effect. With adjustments for clustering and predictors, the result for continuous abstinence at one year was odds ratio (OR) $1.23(95 \% \mathrm{Cl} 1.07$ to $1.41, \mathrm{n}=$ $33,215)$. Crude abstinence rates were $15.47 \%$ versus $13.74 \%$, so the absolute effect was small. An earlier study of 25,996 participants reported $18 \%$ abstinence in the intervention group compared with $17 \%$ in the control group, however the denominators for these percentages were unclear (Klesges 1999). A study of 2781 female naval recruits provided the intervention after the end of training and did not detect an effect of mail (RR $1.03,95 \% \mathrm{Cl} 0.93$ to 1.14 ) or phone intervention ( $\mathrm{RR} 0.93,95 \% \mathrm{Cl} 0.84$ to 1.04 ); fewer than $3 \%$ of participants called the helpline for counselling (Conway 2004).

\section{Behavioural interventions in unselected populations}

\section{Behavioural interventions for unaided abstainers}

We found no evidence of a benefit of interventions to prevent relapse in people who had initially quit unaided (Killen 1990; Fortmann 1995; Brandon 2000; Borland 2004; Brandon 2004) ( $\mathrm{n}=$ 3561, RR $1.06,95 \% \mathrm{Cl} 0.96$ to $1.16, \mathrm{I}^{2}=1 \%$; Analysis 3.1). All five studies used low-intensity self-help interventions.

\section{Behavioural interventions for assisted abstainers}

We detected no long-term benefit of skills-based interventions in preventing relapse in 11 studies in which abstaining smokers were randomly assigned after they had taken part in a formal treatment programme $\left(\mathrm{n}=5523\right.$, RR $0.98,95 \% \mathrm{Cl} 0.87$ to $1.11, \mathrm{I}^{2}=52 \%$; Analysis 4.1). There was also no difference between higher intensity interventions (four studies, $\mathrm{n}=1121, \mathrm{RR} 1.06,95 \% \mathrm{Cl} 0.82$ to $1.36, \mathrm{I}^{2}$ $=54 \%$ ) and lower intensity interventions (seven studies, $n=4332$, RR $0.95,95 \% \mathrm{Cl} 0.82$ to $1.09, \mathrm{I}^{2}=49 \%$ ). This meta-analysis compared the most intensive intervention with the least intensive control in the studies with more than two arms, except in Cheung 2015, where two intervention arms were combined, and McDaniel 2015, where two intervention arms of differing intensities were listed separately compared with a split control group. Using different comparison conditions did not change the conclusion.

One study compared workplace group counselling with proactive phone counselling post-cessation and did not detect a significant difference between the two at 12 months (workplace versus phone, RR $1.07,95 \% \mathrm{Cl} 0.88$ to 1.31; analysis not shown, Mayer 2010).

\section{Pharmacological interventions}

Pharmacological interventions for short-term unaided abstainers

Pooled results of two large studies of nicotine gum detected a small effect (Killen 1990; Fortmann 1995) ( $n=2261$, RR 1.24, 95\% Cl 1.04 to $1.47, I^{2}=56 \%$; Analysis 6.1 ). In both of these studies, the period of unassisted abstinence was short, and these studies were distinct 
from the next group, in which a more extended period of abstinence was required before the relapse prevention phase was initiated.

Pharmacological interventions for abstainers after cessation therapy

Pooling two studies of NRT (Covey 2007 using gum and Croghan 2007 using inhaler, both with factorial designs entered separately) did not reveal a long-term effect $(n=553, \mathrm{RR} 1.04,95 \% \mathrm{Cl} 0.77$ to $1.40, \mathrm{I}^{2}=0 \%$; Analysis 5.1). This contrasted with the two studies discussed in the previous section. It is worth noting that adherence with oral NRT was low, and that one study replaced the initial patch treatment with $2 \mathrm{mg}$ gum (Covey 2007). It is also worth noting that this analysis included only a small number of participants and hence confidence intervals were very wide.

The estimated effect of extended therapy with bupropion, based on six studies, slightly favoured the intervention and narrowly missed statistical significance $(\mathrm{n}=1697$, RR $1.15,95 \% \mathrm{Cl} 0.98$ to $1.35,1^{2}=0 \%$; Analysis 5.2 ). Whilst there was no evidence of statistical heterogeneity, some clinical heterogeneity was noted in the intervention used for the cessation induction phase, the duration of treatment, and the duration of follow-up after cessation of medication.

Two studies (Covey 2007; Croghan 2007) allowed a comparison between combination therapy of bupropion and NRT versus neither. No significant benefit was detected ( $n=243$, RR 1.18, 95\% $\mathrm{Cl} 0.75$ to 1.87 ; Analysis 5.3), and some evidence of heterogeneity was found $(12=66 \%)$

Two studies (Tonstad 2006; Evins 2014) detected a significant benefit of extended varenicline with some heterogeneity ( $\mathrm{n}=$ 1297, RR $1.23,95 \% \mathrm{Cl} 1.08$ to $1.41,12=82 \%$; Analysis 5.4). Both studies detected statistically significant effects in favour of the intervention.

One further study (STRATUS-WW 2006; $\mathrm{n}=1017$ ) detected a significant benefit of extended treatment with rimonabant (RR 1.29, $95 \% \mathrm{Cl} 1.08$ to 1.55; Analysis 5.5). Rimonabant is not licensed for use in any country, and its manufacturers are no longer supporting its development because of safety concerns (Cahill 2013).

\section{Section 2. Studies randomly assigning smokers before their quit date}

\section{Intervention and control groups matched for contact time}

We found that no benefit was derived from the use of specific relapse prevention components in group or individual format interventions; this finding was based on the results of 10 studies ( $n=872$, RR $0.92,95 \% \mathrm{Cl} 0.72$ to 1.16 ; Analysis 7.1 ). No evidence of heterogeneity was noted $\left(1^{2}=11 \%\right)$. All but Niaura 1999 involved treatment contact for longer than four weeks; therefore, we did not conduct a subgroup analysis by treatment duration. Most studies used a skills-training approach, so we did not conduct a subgroup analysis by treatment type.

One study with two arms, comparing different versions of a selfhelp programme, did not detect a difference in quit rates (Curry $1988, \mathrm{n}=91$, RR 1.52, 95\% Cl 0.67 to 3.46; Analysis 7.2).
Intervention and control arms not matched for contact time or duration

\section{Behavioural interventions}

Varying intensity of face-to-face intervention

We detected no effect in seven studies that tested extended faceto-face contact (Killen 1984; Hall 1985; Brandon 1987; Hall 1987; Buchkremer 1991 1; Lifrak 1997; Shoptaw 2002) ( $=699$, RR 1.02, $95 \% \mathrm{Cl} 0.80$ to $1.29, \mathrm{I}^{2}=4 \%$; Analysis 8.1 ). There was no evidence of differences between subgroups based on the number of control group contacts.

\section{Extended contact using proactive telephone calls}

Three studies (Lando 1996; Segan 2011; Blebil 2014) did detect a benefit of providing extended contact by telephone, though the lower end of the confidence interval encompassed no effect $(\mathrm{n}=2758$, RR 1.18, 95\% Cl 0.93 to 1.49; Analysis 9.1.1). Statistical heterogeneity was moderate $\left(1^{2}=67 \%\right)$, likely because of differences in the initial cessation programme: In Lando 1996, participants received additional calls after an intensive eight-week group programme, whereas in Segan 2011, additional calls were tested as an adjunct to standard quitline treatment and in Blebil 2014, participants received extra calls in adjunct to smoking clinic visits.

\section{Additional print-based support}

Three studies (Sheffer 2010; Unrod 2016; Simmons 2018) detected a benefit from providing additional print-based support $(n=6224$, RR $1.16,95 \% \mathrm{Cl} 1.01$ to $1.33, \mathrm{I}^{2}=70 \%$; Analysis 9.1.2), though confidence intervals also encompassed no meaningful benefit. In the main analysis, we split the control groups of two studies with multiple intervention arms (Unrod 2016 and Simmons 2018) to avoid double-counting. We conducted a sensitivity analysis combining the intervention arms; effects were consistent with the main result though the confidence interval now crossed one (RR $1.20,95 \% \mathrm{Cl} 0.96$ to $1.50, \mathrm{I}^{2}=83 \%$ ). Further, Sheffer 2010 reported significant baseline imbalances between study groups, so we conducted another sensitivity analysis removing the study, again not detecting a benefit ( $R R 1.13,95 \% \mathrm{Cl} 0.97$ to $1.31, \mathrm{I}^{2}=72 \%$ ).

\section{Additional intervention delivered by computer or mobile phone}

Four studies (Japuntich 2006; Wetter 2011; Hicks 2017; Durmaz 2019) did not detect a benefit of providing additional support via computer or mobile phone $\left(\mathrm{n}=729\right.$, RR $1.19,95 \% \mathrm{Cl} 0.85$ to $1.66, \mathrm{I}^{2}$ = 26\%; Analysis 9.1.3).

\section{Formulation of coping strategies}

Van Osch 2008 evaluated the impact of asking participants of a Quit and Win contest to formulate coping strategies in advance and also did not detect an effect $(n=1566$, RR $1.27,95 \% \mathrm{Cl} 0.97$ to 1.67 ; Analysis 9.1.4).

\section{Combined behavioural and pharmacological interventions}

Joseph 2011 tested extended therapy with both NRT and proactive telephone counselling and did not detect a significant effect at 18 months ( $n=443$, RR 1.28, 95\% Cl 0.94 to 1.75; Analysis 9.2). 


\section{Section 3. Subgroup analysis by duration of prior abstinence}

For analyses of studies randomising abstainers, we conducted subgroup analyses grouping studies by the duration of prior abstinence of participants (analyses 10 to 15). We grouped studies based on whether participants had been abstinent for four or more weeks, less than four weeks, or if prior abstinence varied or was not adequately specified. We summarised the duration of prior abstinence of participants in studies recruiting abstainers in Table 1. Only analysis 10.2 and analysis 13.1 included enough studies in the different subgroups for a meaningful subgroup comparison. Neither analysis detected differences between subgroups. The $P$ value for subgroup difference between the $\geq 4$ weeks and $<4$ weeks groups in Analysis 10.2 was 0.83 , with $1^{2}=0 \%$. The $P$ value for subgroup difference between the $\geq 4$ weeks and $<4$ weeks groups in Analysis 13.1 was 0.97 , with $\mathrm{I}^{2}=0 \%$.

\section{DISCUSSION}

\section{Summary of main results}

As discussed further below, studies that randomised abstainers provided the best evidence on the effectiveness of relapse prevention interventions, and we focus on these when summarising main results and drawing conclusions. In this review, we did not detect a clinically significant effect of existing behavioural 'relapse prevention' methods for people quitting smoking. Our certainty in the evidence for behavioural methods for relapse prevention in people randomised after assisted quitting was moderate and was limited by heterogeneity (Summary of findings for the main comparison), meaning further studies may change our estimate of effect.

Results for some pharmacotherapies in abstainers were more encouraging, with the certainty of evidence ranging from low to moderate (Summary of findings 2). The two studies of extended varenicline found it to be beneficial in preventing relapse. Certainty in the effect estimate was moderate, limited by statistical heterogeneity. The study of rimonabant also detected a significant effect in favour of the intervention, but this drug has been withdrawn from the market because of concerns about its safety. Whilst nicotine replacement therapy (NRT) was found to help in unassisted abstainers, two studies of extended NRT in assisted abstainers did not detect an effect, but the certainty of evidence was low. The two comparisons of bupropion plus NRT versus double placebo did not detect an effect either, and the six studies of bupropion, when combined, narrowly missed significance; none yielded a significant result on their own. We graded the certainty of evidence for this comparison as moderate due to imprecision, meaning that future studies may have an important impact on our confidence in the estimate of effect and may change the estimate.

In discussing the further implications of this review, we first comment on the technical aspects and limitations and attempt to make some methodological recommendations for future work in this area. We then discuss some of the conclusions pertaining to different treatment formats.

\section{Inclusion and exclusion of studies}

Identifying criteria for including studies in this review was difficult. We included all studies that randomly assigned abstainers, as these provide the best test of interventions aimed at maintaining abstinence. Studies randomly assigning smokers before quitting presented a challenge. Although such studies may be described as studies of relapse prevention, they usually test primarily smoking cessation interventions, with interventions aimed at preventing relapse added to the treatment programme but not analysed separately. One of the problems involved in considering the inclusion of smoking cessation studies with a specified relapse prevention component is that they were sometimes similar in design to other studies that did not specifically mention relapse prevention in their title or abstract but used virtually identical methods. In our initial analyses, we included a wider group of studies (e.g. Goldstein 1989; Zelman 1992; Hall 1994; Hall 1996; Brown 2001), but in the end we decided to restrict the analysis of studies randomly assigning smokers to those that mentioned relapse prevention explicitly. The results of the review were not affected by this decision, as the excluded studies were also small and did not show significant treatment effects. We also excluded a small number of studies that randomly assigned smokers before quitting and that explicitly included relapse prevention or maintenance but concerned smoking cessation interventions that are already covered by three other Cochrane reviews: exercise (Ussher 2012), aversive smoking (Hajek 2001a), and interventions for hospitalised smokers (Rigotti 2012).

The negative results of the individual studies are fairly consistent, and it is unlikely that using alternative inclusion criteria would lead to different conclusions; however, identifying appropriate studies in this challenging area is difficult. Possible limitations of the review are that we may not have identified all relevant research and that we may not have pooled studies appropriately. We think it is unlikely that large effects have been missed in the studies conducted so far, but, in some cases, the studies were too small to allow detection of moderate effects.

\section{The two study designs according to the timing of randomisation}

The key methodological feature of existing attempts to evaluate relapse prevention interventions concerns the time when participants were randomly assigned (i.e. before or after they stopped smoking).

The main logical argument in favour of randomly assigning smokers before they stop smoking is that much relapse prevention advice could be relevant even in the very first stages of quitting smoking. On the practical side, although it is relatively easy to attract smokers to start an experimental treatment, the samples would be much smaller if only those abstinent at the end of treatment were enrolled. However, combining cessation and relapse prevention reduces the power to detect specific relapse prevention effects. The primary outcome variable is normally the abstinence rate at follow-up, and it is difficult to differentiate any effects that the intervention may have had on the initial smoking cessation from effects on preventing relapse in smokers who were initially successful. The initial success or failure is likely to be determined by a number of intervention and participant variables other than the relapse prevention component, which is usually only a small part of the overall programme. One way to resolve this problem could be to focus the analysis on the initial successes only. However, none of the existing studies used this approach, and the published data usually did not include sufficient details to allow survival analysis. Even if relapse rates for initially successful abstainers were available, the relapse prevention effect would be difficult 
to interpret when comparison groups have different short-term cessation rates.

Randomly assigning only those smokers who have made a successful quit attempt represents a stronger study design. As cessation interventions are segregated from relapse prevention interventions, the results cannot be skewed by uneven initial cessation rates, any relapse prevention effects are more likely to be detected, and the results are easy to interpret. On the downside, this approach requires greater effort to recruit sufficient samples. Among existing studies of behavioural treatments using this approach, many used spontaneous abstainers, such as pregnant women. The difference between the initial smoking cessation and later relapse prevention treatment is much clearer in pharmacotherapy.

The studies that randomly assigned abstainers varied considerably in the periods of time for which participants had already abstained from smoking (i.e. from 24 hours to 16 months). There seemed to be broad agreement on the conceptual distinction between 'stopping smoking' and 'staying quit' and on the common understanding of the concept of relapse, but accepted operational definitions were lacking, although some suggestions have been made (OssipKlein 1986). It seems clear that abstinence for a period of time close to inter-cigarette intervals, or overnight abstinence, does not constitute cessation of smoking, and that a return to smoking after several weeks of total abstinence can be classified as a relapse. However, common behaviours such as abstinence for 24 hours or smoking only a few cigarettes every few days, become more difficult to classify. Little consensus has been reached on what amount of smoking after what type of smoking restraint over what period of time represents a relapse as opposed to the initial failure to stop smoking. Ideally, future relapse prevention studies should follow the example of existing drug trials and should use sufficiently long periods of no smoking and sufficiently strict definitions of the initial abstinence and outcome to avoid areas of contention.

\section{Some methodological recommendations}

The ideal study of a relapse prevention intervention aimed at complementing existing treatments for smokers seeking help would randomly assign smokers who were abstinent continuously and completely for at least four weeks. An appropriate outcome measure would be continuous lapse-free abstinence of at least six months when the intervention was aimed at avoiding lapses, but some lapses would have to be allowed when the intervention was aimed at helping patients to cope with lapses should these occur. General agreement has been reached that, for dependent smokers seeking treatment, becoming an occasional smoker is usually not an option, and for long-term success, any lapses would have to cease eventually. It would seem sensible to allow lapses over a limited 'period of grace' (e.g. three or even six months), followed by at least six months of lapse-free abstinence. Many studies in this review were seriously underpowered, using 15 or 20 participants per condition. Future research needs to acknowledge that any effects are likely to be small, and that large samples will be needed to avoid type 2 errors.

\section{Interpreting the review results}

The 48 studies that randomly assigned abstainers provide the main interpretable body of data in this field. The results of both special population studies and studies of smokers seeking treatment suggest that behavioural brief interventions and interventions relying on written materials, mailings, and telephone contact are ineffective for relapse prevention. It may be important to note that more intensive approaches were examined in only a handful of studies, and some were too small to allow detection of any realistic effect. Although intensive interventions in this area need to resolve the likely problems related to intervention costs and patient attendance, further work on such treatments may be needed.

Rates of abstinence were highly variable across studies because of such factors as the population studied, the intensity of any cessation intervention provided, the period for which abstinence had already been maintained, the length of follow-up, and the definition of cessation. Because of obvious problems with comparisons of success rates across studies (Hajek 1994), we did not discuss results in terms of the absolute abstinence rates achieved.

With regard to the contents of the behavioural interventions, the negative results concerned primarily the traditional skills-based approach, which holds a virtual monopoly in this field. It remains possible that the original concept is valid (i.e. that recent exsmokers can benefit from being taught how to identify tempting situations), and that effective strategies for coping with such situations can also be taught. If this is the case, the negative results could have been due to the fact that such skills were not being taught effectively. If future studies examine this approach, investigators should try to check whether participants acquired and practised the skills taught. However, an alternative possibility has to be considered - that, despite the strong intuitive validity and popularity of the classic relapse prevention procedures, they do not produce the desired effect. Future studies may be better advised to focus on alternative approaches not studied extensively or at all so far, such as opportunistic use of nicotine replacement, contingency management, social support, cue exposure (only imaginary exposure has been studied so far), interventions aimed at maintaining abstainers' morale and awareness of the danger of slips, and so forth.

Regarding pharmacological interventions, some large and wellconducted studies have investigated the extended use of bupropion and varenicline; however, NRT has mostly been studied only in relatively small samples, as an add-on to bupropion trials and in paradigms likely to generate low treatment compliance, which lower the chance of detection of effects of the expected size. Given the good acceptability, safety, and cost profile of NRT, further studies of extended use of traditional NRT and e-cigarettes to prevent relapse in abstainers are needed.

\section{Agreements and disagreements with other studies or reviews}

One large review by Coleman and colleagues of relapse prevention interventions for abstinent smokers detected more positive results than ours for some outcomes (Agboola 2010; Coleman 2010). In particular, although we did not detect any significant effects in pooled comparisons, Coleman and colleagues concluded that selfhelp materials, bupropion, and nicotine replacement therapy were effective at six months and longer. We investigated the reasons for these discrepancies.

Coleman and colleagues used similar search strategies and inclusion criteria to ours, hence at the time our included studies lists mapped closely onto each other. Their review did not 
include some new studies added in the most recent updates, nor did it include one study from previous versions of this review (Klesges 2006 was excluded because participants included some never-smokers). However, the differences in conclusions were not attributable to the exclusion of these studies. Differences between results for the most part were due to decisions about subgroups and outcomes presented.

Although our meta-analysis of bupropion included an additional two studies (Killen 2006; Hays 2009) to the four presented by Coleman and colleagues, the reason for the discrepancy in our pooled results from bupropion studies lies in the outcome data used. Coleman and colleagues used different definitions of abstinence and different denominators; in particular, they did not always count dropouts as continuing smokers. We followed the standard methods used by the Cochrane Tobacco Addiction Group, which resulted in a more conservative outcome. The difference in NRT results was attributable to subgroup decisions. Our pooled results suggested that NRT could be effective in unaided abstainers but did not detect an effect in assisted abstainers; Coleman and colleagues merged the two groups and detected a significant effect overall. Finally, Coleman and colleagues detected a significant effect of written self-help at long-term follow-up. The three included studies from their analysis were included in our analysis of behavioural interventions for unaided abstainers, and our analysis contained an additional two studies. However, the exclusion of these two studies did not change the overall effect in a sensitivity analysis; rather, the difference in results was largely due to the data presented for Brandon 2000. This was a factorial study that tested access to a quitline and repeated mailings; whereas Coleman and colleagues compared the arms that received mailings with the arms that did not (quitline only and control), we compared all intervention arms (quitline, quitline plus mailings, mailings only) with the control arm and used slightly different data obtained via correspondence with the author.

With the exception of these three analyses, the results from Coleman and colleagues were consistent with our own.

The Cochrane Review of nicotine receptor partial agonists included the same studies of extended varenicline treatment and agreed with our findings (Cahill 2016). However they also noted that the integrity of the blinding in the studies may have been compromised because the participants had already used open-label varenicline to achieve initial abstinence. Lindson 2019 compares different regimens of NRT, and the review contains in-depth analyses of treatment duration for NRT in current smokers. No evidence was found to support extended use of NRT in this population, but evidence was judged to be of low certainty.

\section{AUTHORS' CONCLUSIONS}

\section{Implications for practice}

In people who have successfully stopped smoking using pharmacotherapy, there are mixed results regarding extending pharmacotherapy for longer than is standard. Extended treatment with varenicline helps to prevent relapse. The evidence does not show a benefit from extended treatment with bupropion in preventing relapse, but this evidence is limited by imprecision, and the confidence intervals mean we cannot rule out a clinically important benefit at this stage. Evidence from two studies has not shown a benefit from extended nicotine replacement therapy in assisted smokers, but it may be effective in unassisted smokers.

The available evidence does not support the use of behavioural interventions to help smokers who have successfully quit to avoid relapsing. This evidence focused on interventions that encouraged identifying and resolving tempting situations, as well as minimal interventions using one-off sessions and written materials. There is limited evidence available on alternative approaches.

\section{Implications for research}

The current research has limitations both in the methodology and in the treatment approaches tested. Future researchers, especially those exploring behavioural interventions, should take account of this in designing studies of adequate methodology and sample size, and in examining alternatives to attempts to teach skills to cope with risk situations. In pharmacological research, further studies of extended treatment with front-line smoking cessation pharmacotherapies and/or e-cigarettes in abstainers are needed.

\section{ACKNOWLEDGEMENTS}

We would like to thank Sue Curry and Roger Secker-Walker for comments on earlier drafts of this review, as well as Esther Coren for consumer input. Hitomi Kobayashi assisted by translating a study in Japanese, Darius Razavi provided additional information on Mayer 2010 and Minxing Chen and David Wetter provided additional data on Wetter 2011. We would also like to thank Lindsay Stead and Timothy Lancaster who were authors of previous versions of this review, and Sandra Wilcox and Lee Bromhead for reviewing the plain language summary.

We are also very grateful to our peer reviewers:

- Professor Andrew J. Saxon, MD, Department of Psychiatry \& Behavioral Sciences, University of Washington School of Medicine, Director, Center of Excellence in Substance Abuse Treatment and Education (CESATE), VA Puget Sound Health Care System

- A. Eden Evins, MD, MPH, Founding Director, Massachusetts General Hospital Center for Addiction Medicine, Cox Family Professor of Psychiatry in the Field of Addiction Medicine, Harvard Medical School

This project was supported by the National Institute for Health Research (NIHR), via Cochrane Infrastructure and Cochrane Programme grant funding to the Cochrane Tobacco Addiction Group. The views and opinions expressed therein are those of the authors and do not necessarily reflect those of the Systematic Reviews Programme, NIHR, NHS or the Department of Health and Social Care. JHB is also part-funded by the NIHR Oxford Biomedical Research Centre (BRC). 


\section{R E F E R E N C E S}

\section{References to studies included in this review}

Becona 1997 \{published data only\}

Becona $\mathrm{E}$, Vazquez FL. Does using relapse prevention increase the efficacy of a program for smoking cessation? An empirical study. Psychological Reports 1997;81(1):291-6.

\section{Blebil 2014 \{published data only\}}

Blebil AQ, Sulaiman SA, Hassali MA, Dujaili JA, Zin AM. Impact of additional counselling sessions through phone calls on smoking cessation outcomes among smokers in Penang State, Malaysia. BMC Public Health 2014;14:460.

\section{Blyth 2015 \{published data only\}}

* Blyth A, Maskrey V, Notley C, Barton GR, Brown TJ, Aveyard P, et al. Effectiveness and economic evaluation of self-help educational materials for the prevention of smoking relapse: randomised controlled trial. Health Technology Assessment 2015;19(59):1-70.

Maskrey V, Blyth A, Brown TJ, Barton GR, Notley C, Aveyard P, et al. Self-help educational booklets for the prevention of smoking relapse following smoking cessation treatment: a randomized controlled trial. Addiction 2015;110(12):No Pagination Specified.

Notley C, Blyth A, Maskrey V, Karavadra B, Brown T, Holland R, et al. Self-help materials for smoking relapse prevention: a process evaluation of the SHARPISH randomized controlled trial. Journal of Public Health 2018;40(1):98-105.

Song F, Bachmann MO, Aveyard P, Barton GR, Brown TJ, Maskrey V, et al. Relapse to smoking and health-related quality of life: secondary analysis of data from a study of smoking relapse prevention. PLOS One 2018;13(11):e0205992.

Song F, Holland R, Barton GR, Bachmann M, Blyth A, Maskrey V, et al. Self-help materials for the prevention of smoking relapse: study protocol for a randomized controlled trial. Trials 2012;13:69.

\section{Borland 2004 \{published data only\}}

Borland R, Balmford J, Hunt D. The effectiveness of personally tailored computer-generated advice letters for smoking cessation. Addiction 2004;99:369-77.

\section{Brandon 1987 \{published data only\}}

Brandon TH, Zelman DC, Baker TB. Effects of maintenance sessions on smoking relapse: delaying the inevitable?. Journal of Consulting and Clinical Psychology 1987;55:780-2.

\section{Brandon 2000 \{published and unpublished data\}}

Brandon TH, Collins BN, Juliano LM, Lazev AB. Preventing relapse among former smokers: a comparison of minimal interventions through telephone and mail. Journal of Consulting and Clinical Psychology 2000;68:103-13.

\section{Brandon 2004 \{published and unpublished data\}}

* Brandon TH, Meade CD, Herzog TA, Chirikos TN, Webb MS, Cantor AB. Efficacy and cost-effectiveness of a minimal intervention to prevent smoking relapse: dismantling the effects of amount of content versus contact. Journal of Consulting and Clinical Psychology 2004;72:797-800.

Chirikos TN, Herzog TA, Meade CD, Webb MS, Brandon TH. Costeffectiveness analysis of a complementary health intervention: the case of smoking relapse prevention. International Journal of Technology Assessment in Health Care 2004;20:475-80.

Brandon 2012 \{published data only\}

Brandon TH, Simmons VN, Meade CD, Quinn GP, Lopez Khoury EN, Sutton SK, et al. Self-help booklets for preventing postpartum smoking relapse: a randomized trial. American Journal of Public Health 2012;102(11):2109-15.

\section{Brandstein 2012 \{published data only\}}

Brandstein K. A proactive smoking cessation intervention with hospitalized smokers: a randomized controlled trial. Dissertation Abstracts International 2012;72(8-B):4600.

Buchkremer 19911 \{published data only\}

Buchkremer G, Minneker E, Block M. Smoking-cessation treatment combining transdermal nicotine substitution with behavioral therapy. Pharmacopsychiatry 1991;24:96-102.

Buchkremer 19912 \{published data only\}

Buchkremer G, Minneker E, Block M. Smoking-cessation treatment combining transdermal nicotine substitution with behavioral therapy. Pharmacopsychiatry 1991;24:96-102.

Campos 2018 \{published data only\}

Campos ACF, Nani ASF, Fonseca VADS, Silva EN, Castro MCS, Martins WA. Comparison of two smoking cessation interventions for inpatients. Jornal Brasileiro de Pneumologia 2018;44(3):195-201.

\section{Cheung 2015 \{published data only\}}

Cheung YT, Chan CH, Lai CK, Chan WF, Wang MP, Li HC, et al. Using WhatsApp and Facebook online social groups for smoking relapse prevention for recent quitters: a pilot pragmatic cluster randomized controlled trial. Journal of Medical Internet Research 2015;17(10):e238.

\section{Coleman-Cowger 2018 \{published data only\}}

Coleman-Cowger VH, Mark KS, Rosenberry ZR, Koszowski B, Terplan M. A pilot randomized controlled trial of a phone-based intervention for smoking cessation and relapse prevention in the postpartum period. Journal of Addiction Medicine 2018;12(3):193-200.

\section{Conway 2004 \{published data only\}}

* Conway TL, Woodruff SI, Edwards CC, Elder JP, Hurtado SL, Hervig LK. Operation Stay Quit: evaluation of two smoking relapse prevention strategies for women after involuntary cessation during US Navy recruit training. Military Medicine 2004;169:236-42.

Edwards CC, Woodruff SI, Conway TL. Operation Stay Quit: preventing smoking relapse among US Navy women. American Journal of Health Behavior 1999;23(5):352-5. 


\section{Covey 2007 \{published data only\}}

Covey LS, Glassman AH, Jiang H, Fried J, Masmela J, LoDuca C, et al. A randomized trial of bupropion and/or nicotine gum as maintenance treatment for preventing smoking relapse. Addiction 2007;102(8):1292-302.

\section{Croghan 2007 \{published data only\}}

Croghan IT, Hurt RD, Dakhil SR, Croghan GA, Sloan JA, Novotny PJ, et al. Randomized comparison of a nicotine inhaler and bupropion for smoking cessation and relapse prevention. Mayo Clinic Proceedings 2007;82(2):186-95.

\section{Cummins 2016 \{published data only\}}

Cummins S, Zhu SH, Gamst A, Kirby C, Brandstein K, KlonoffCohen $\mathrm{H}$, et al. Nicotine patches and quitline counseling to help hospitalized smokers stay quit: study protocol for a randomized controlled trial. Trials 2012;13(1):128.

* Cummins SE, Gamst AC, Brandstein K, Seymann GB, KlonoffCohen $\mathrm{H}$, Kirby $\mathrm{CA}$, et al. Helping hospitalized smokers: a factorial RCT of nicotine patches and counseling. American Journal of Preventive Medicine 2016;51(4):578-86.

\section{Curry 1988 \{published data only\}}

Curry SJ, Marlatt GA, Gordon J, Baer JS. A comparison of alternative theoretical approaches to smoking cessation and relapse. Health Psychology 1988;7(6):545-56.

\section{Davis 1986 \{published data only\}}

Davis JR, Glaros AG. Relapse prevention and smoking cessation Addictive Behaviors 1986;11:105-14.

\section{Durmaz 2019 \{published data only\}}

Durmaz S, Ergin I, Durusoy R, Hassoy H, Caliskan A, Okyay P. WhatsApp embedded in routine service delivery for smoking cessation: effects on abstinence rates in a randomized controlled study. BMC Public Health 2019;19(1):387.

\section{Emmons 1988 \{published data only\}}

Emmons KM, Emont SL, Collins RL, Weidner G. Relapse prevention versus broad spectrum treatment for smoking cessation: a comparison of efficacy. Journal of Substance Abuse 1988;1:79-89.

\section{Ershoff 1995 \{published data only\}}

Ershoff DH, Quinn VP, Mullen PD. Relapse prevention among women who stop smoking early in pregnancy: a randomized clinical trial of a self-help intervention. American Journal of Preventive Medicine 1995;11(3):178-84.

\section{Evins 2014 \{published data only\}}

* Evins AE, Cather C, Pratt SA, Pachas GN, Hoeppner SS, Goff DC, et al. Maintenance treatment with varenicline for smoking cessation in patients with schizophrenia and bipolar disorder: a randomized clinical trial. JAMA 2014;311(2):145-54.

Evins AE, Hoeppner SS, Schoenfeld DA, Hoeppner BB, Cather C, Pachas GN, et al. Maintenance pharmacotherapy normalizes the relapse curve in recently abstinent tobacco smokers with schizophrenia and bipolar disorder. Schizophrenia Research 2017;183:124-9.
NCT00621777. A study of varenicline for prevention of relapse to smoking in patients with schizophrenia (SCRP). clinicaltrials.gov/ct2/show/NCT00621777 (first received 2015).

Thorndike AN, Achtyes ED, Cather C, Pratt S, Pachas GN, Hoeppner $\mathrm{S}$, et al. Weight gain and 10-year cardiovascular risk with sustained tobacco abstinence in smokers with serious mental illness: a subgroup analysis of a randomized trial. Journal of Clinical Psychiatry 2016;77(3):e320-6.

\section{Fortmann 1995 \{published data only\}}

Fortmann SP, Killen JD. Nicotine gum and self-help behavioral treatment for smoking relapse prevention: results from a trial using population-based recruitment. Journal of Consulting and Clinical Psychology 1995;63(3):460-8.

Hajek 2001 \{published data only\}

Hajek P, West R, Lee A, Foulds J, Owen L, Eiser JR, et al. Randomized controlled trial of a midwife-delivered brief smoking cessation intervention in pregnancy. Addiction 2001;96(3):485-94.

\section{Hajek 2002 \{published data only\}}

Hajek P, Taylor TZ, Mills P. Brief intervention during hospital admission to help patients to give up smoking after myocardial infarction and bypass surgery: randomised controlled trial. BMJ 2002;324:87-9.

Hall 1984 \{published data only\}

Hall SM, Rugg D, Tunstall C, Jones RT. Preventing relapse to cigarette smoking by behavioral skill training. Journal of Consulting and Clinical Psychology 1984;52(3):372-82.

\section{Hall 1985 \{published data only\}}

Hall SM, Killen JD. Psychological and pharmacological approaches to smoking relapse prevention. NIDA Research Monograph 1985;53:131-43.

* Hall SM, Tunstall C, Rugg D, Jones R, Benowitz N. Nicotine gum and behavioral treatment in smoking cessation. Journal of Consulting and Clinical Psychology 1985;53:256-8.

Hall 1987 \{published data only\}

* Hall SM, Tunstall CD, Ginsberg D, Benowitz NL, Jones RT. Nicotine gum and behavioral treatment: a placebo controlled trial. Journal of Consulting and Clinical Psychology 1987;55(4):603-5

\section{Hannöver 2009 \{published data only\}}

* Hannöver W, Thyrian JR, Roske K, Grempler J, Rumpf HJ, John U, et al. Smoking cessation and relapse prevention for postpartum women: results from a randomized controlled trial at 6, 12, 18 and 24 months. Addictive Behaviors 2009;34:1-8. [DOI: 10.1016/j.addbeh.2008.07.021]

Roske K, Schumann A, Hannöver W, Grempler J, Thyrian JR, Rumpf $\mathrm{HJ}$, et al. Postpartum smoking cessation and relapse prevention intervention: a structural equation modeling application to behavioral and non-behavioral outcomes of a randomized controlled trial. Journal of Health Psychology 2008;13:556-68. 
Thyrian JR, Freyer-Adam J, Hannöver W, Roske K, Mentzel F, Kufeld $C$, et al. Adherence to the principles of motivational interviewing, clients' characteristics and behavior outcome in a smoking cessation and relapse prevention trial in women postpartum. Addictive Behaviors 2007;32:2297-303.

\section{Hasuo 2004 \{published data only\}}

Hasuo S, Tanaka H, Oshima A. Efficacy of a smoking relapse prevention program by postdischarge telephone contacts: a randomized trial. Nippon Koshu Eisei Zasshi 2004;51:403-12.

\section{Hayes 2018 \{published data only\}}

Hayes KA, Jackson C, Dickinson DM, Miller AL. Providing antismoking socialization to children after quitting smoking: does it help parents stay quit?. American Journal of Health Promotion 2018;32(5):1257-63.

\section{Hays 2001 \{published data only\}}

Abel GA, Hays JT, Decker PA, Croghan GA, Kuter DJ, Rigotti NA. Effects of biochemically confirmed smoking cessation on white blood cell count. Mayo Clinic Proceedings 2005;80:1022-8.

Cox LS, Patten CA, Niaura RS, Decker PA, Rigotti N, Sachs DPL, et al. Efficacy of bupropion for relapse prevention in smokers with and without a past history of major depression. Journal of General Internal Medicine 2004;19:828-34.

Durcan MJ, Deener G, White J, Johnston JA, Gonzales D, Niaura R, et al. The effect of bupropion sustained-release on cigarette craving after smoking cessation. Clinical Therapeutics 2002;24(4):540-51.

Durcan MJ, Johnston JA, White J, Gonzales D, Sachs DP, Rigotti N, et al. Bupropion SR for relapse prevention: a "slipsallowed" analysis. American Journal of Health Behavior 2004;28:456-63.

Gonzales D, Bjornson W, Durcan MJ, White JD, Johnston JA, Buist AS, et al. Effects of gender on relapse prevention in smokers treated with bupropion SR. American Journal of Preventive Medicine 2002;22(4):234-9.

* Hays JT, Hurt RD, Rigotti NA, Niaura R, Gonzales D, Durcan MJ, et al. Sustained-release bupropion for pharmacologic relapse prevention after smoking cessation. A randomized, controlled trial. Annals of Internal Medicine 2001;135:423-33.

Hurt RD, Wolter TD, Rigotti N, Hays JT, Niaura R, Durcan MJ, et al. Bupropion for pharmacologic relapse prevention to smoking - predictors of outcome. Addictive Behaviors 2002;27(4):493-507.

\section{Hays 2009 \{published data only\}}

* Hays JT, Hurt RD, Decker PA, Croghan IT, Offord KP, Patten CA. A randomized, controlled trial of bupropion sustained-release for preventing tobacco relapse in recovering alcoholics. Nicotine and Tobacco Research 2009;11(7):859-67.

Hurt RD, Patten CA, Offord KP, Croghan IT, Decker PA, Morris RA, et al. Treating nondepressed smokers with alcohol dependence in sustained full remission: nicotine patch therapy tailored to baseline serum cotinine. Journal of Studies on Alcohol 2005;66(4):506-16.

\section{Hicks 2017 \{published data only\}}

Hicks TA, Thomas SP, Wilson SM, Calhoun PS, Kuhn ER, Beckham JC. A preliminary investigation of a relapse prevention mobile application to maintain smoking abstinence among individuals with posttraumatic stress disorder. Journal of Dual Diagnosis 2017;13(1):15-20.

\section{Hurt 2003 \{published data only\}}

Hurt RD, Krook JE, Croghan IT, Loprinzi CL, Sloan JA, Novotny PJ, et al. Nicotine patch therapy based on smoking rate followed by bupropion for prevention of relapse to smoking. Journal of Clinical Oncology 2003;21:914-20.

\section{Japuntich 2006 \{published data only\}}

Japuntich SJ, Zehner ME, Smith SS, Jorenby DE, Valdez JA, Fiore MC, et al. Smoking cessation via the internet: a randomized clinical trial of an internet intervention as adjuvant treatment in a smoking cessation intervention. Nicotine \& Tobacco Research 2006;8 Suppl 1:S59-67.

\section{Joseph 2011 \{published data only\}}

Joseph AM, Fu SS, Lindgren B, Rothman AJ, Kodl M, Lando H, et al. Chronic disease management for tobacco dependence: a randomized, controlled trial. Archives of Internal Medicine 2011;171(21):1894-900.

\section{Killen 1984 \{published data only\}}

* Killen JD, Maccoby N, Taylor CB. Nicotine gum and selfregulation training in smoking relapse prevention. Behavior Therapy 1984;15:234-48.

\section{Killen 1990 \{published and unpublished data\}}

Killen JD, Fortmann SP, Newman B, Varady A. Evaluation of a treatment approach combining nicotine gum with self-guided behavioral treatments for smoking relapse prevention. Journal of Consulting and Clinical Psychology 1990;58:85-92.

\section{Killen 2006 \{published data only\}}

Killen JD, Fortmann SP, Murphy GM Jr, Hayward C, Arredondo C, Cromp D, et al. Extended treatment with bupropion SR for cigarette smoking cessation. Journal of Consulting and Clinical Psychology 2006;74(2):286-94.

\section{Klesges 1999 \{published data only\}}

Klesges RC, Haddock CK, Lando H, Talcott GW. Efficacy of forced smoking cessation and an adjunctive behavioral treatment on long-term smoking rates. Journal of Consulting and Clinical Psychology 1999;67:952-8.

\section{Klesges 2006 \{published data only\}}

* Klesges RC, Debon M, Vander Weg MW, Haddock CK, Lando HA, Relyea GE, et al. Efficacy of a tailored tobacco control program on long-term use in a population of U.S. military troops. Journal of Consulting \& Clinical Psychology 2006;74(2):295-306.

Klesges RC, Sherrill-Mittleman D, Ebbert JO, Talcott GW, Debon $\mathrm{M}$. Tobacco use harm reduction, elimination, and escalation in a large military cohort. American Journal of Public Health 2010;100(12):2487-92. 
Lando 1996 \{published data only\}

* Lando HA, Pirie PL, Roski J, McGovern PG, Schmid LA. Promoting abstinence among relapsed chronic smokers: the effect of telephone support. American Journal of Public Health 1996;86:1786-90.

\section{Levine 2016 \{published data only\}}

Katz MH. Preventing smoking relapse after delivery maintaining a pregnant pause. JAMA Internal Medicine 2016;176(4):452

Kolko RP, Emery RL, Cheng Y, Levine MD. Do psychiatric disorders or measures of distress moderate response to postpartum relapse prevention interventions?. Nicotine \& Tobacco Research 2017;19(5):615-22.

* Levine MD, Cheng Y, Marcus MD, Kalarchian MA, Emery RL. Preventing postpartum smoking relapse: a randomized clinical trial. JAMA Internal Medicine 2016;176(4):443-52.

Levine MD, Marcus MD, Kalarchian MA, Cheng Y. Strategies to Avoid Returning to Smoking (STARTS): a randomized controlled trial of postpartum smoking relapse prevention interventions. Contemporary Clinical Trials 2013;36(2):565-73.

\section{Lifrak 1997 \{published data only\}}

Lifrak P, Gariti P, Alterman A, Volpicelli J, O'Brien C. Combining individual relapse prevention counseling with a transdermal nicotine patch for smoking cessation. Journal of Addictive Diseases 1994;13(4):251.

* Lifrak P, Gariti P, Alterman Al, McKay J, Volpicelli J, Sparkman T, et al. Results of two levels of adjunctive treatment used with the nicotine patch. American Journal of Addiction 1997;6:93-8.

\section{Lowe 1997 \{published data only\}}

Lowe JB, Windsor R, Balanda KP, Woodby L. Smoking relapse prevention methods for pregnant women: a formative evaluation. American Journal of Health Promotion 1997;11:244-6.

\section{Mayer 2010 \{published and unpublished data\}}

Mayer C, Vandecasteele H, Bodo M, Primo C, Slachmuylder JL, Kaufman L, et al. Smoking relapse prevention programs and factors that predict abstinence: a controlled study comparing the efficacy of workplace group counselling and proactive phone counselling. Journal of Smoking Cessation 2010;5(1):83-94.

\section{McBride 1999 \{published data only\}}

McBride CM, Curry SJ, Lando HA, Pirie PL, Grothaus LC, Nelson JC. Prevention of relapse in women who quit smoking during pregnancy. American Journal of Public Health 1999;89:706-11.

\section{McBride 2004 \{published data only\}}

McBride CM, Baucom DH, Peterson BL, Pollak KI, Palmer C, Westman E, et al. Prenatal and postpartum smoking abstinence - a partner-assisted approach. American Journal of Preventive Medicine 2004;27(3):232-8.
McDaniel 2015 \{published data only\}

McDaniel AM, Vickerman KA, Stump TE, Monahan PO, Fellows JL, Weaver MT, et al. A randomised controlled trial to prevent smoking relapse among recently quit smokers enrolled in employer and health plan sponsored quitlines. BMJ Open 2015;5(6):e007260.

McNaughton 2013 \{published data only\}

McNaughton B, Frohlich J, Graham A, Young QR. Extended interactive voice response telephony (IVR) for relapse prevention after smoking cessation using varenicline and IVR: a pilot study. BMC Public Health 2013;13:824.

Mermelstein 2003 \{published data only\}

Mermelstein R, Hedeker D, Wong SC. Extended telephone counseling for smoking cessation: does content matter?. Journal of Consulting and Clinical Psychology 2003;71:565-74.

\section{Morasco 2006 \{published data only\}}

Morasco BJ, Dornelas EA, Fischer EH, Oncken C, Lando HA. Spontaneous smoking cessation during pregnancy among ethnic minority women: a preliminary investigation. Addictive Behaviors 2006;31(2):203-10.

Niaura 1999 \{published data only\}

Niaura R, Abrams DB, Shadel WG, Rohsenow DJ, Monti PM, Sirota AD. Cue exposure treatment for smoking relapse prevention: a controlled clinical trial. Addiction 1999;94(5):685-96.

Pbert 2004 \{published data only\}

Pbert L, Ockene JK, Zapka J, Ma YS, Goins KV, Oncken C, et al A community health center smoking-cessation intervention for pregnant and postpartum women. American Journal of Preventive Medicine 2004;26(5):377-85.

Pollak 2016 \{published data only\}

Pollak KI, Fish LJ, Lyna P, Peterson BL, Myers ER, Gao X, et al. Efficacy of a nurse-delivered intervention to prevent and delay postpartum return to smoking: the quit for two trial. Nicotine \& Tobacco Research 2016;18(10):1960-6.

Powell 1981 \{published data only\}

Powell DR, McCann BS. The effects of a multiple treatment program and maintenance procedures on smoking cessation. Preventive Medicine 1981;10:94-104.

Ratner 2000 \{published data only\}

Johnson JL, Ratner PA, Bottorff JL, Hall W, Dahinten S. Preventing smoking relapse in postpartum women. Nursing Research 2000;49:44-52.

Ratner PA, Johnson JL, Bottorff JL. Smoking relapse and early weaning among postpartum women: is there an association?. Birth 1999;26(2):76-82.

* Ratner PA, Johnson JL, Bottorff JL, Dahinten S, Hall W. Twelve-month follow-up of a smoking relapse prevention intervention for postpartum women. Addictive Behaviors 2000;25:81-92. 
Razavi 1999 \{published data only\}

Razavi D, Vandecasteele H, Primo C, Bodo M, Debrier F, Verbist $\mathrm{H}$, et al. Maintaining abstinence from cigarette smoking: effectiveness of group counselling and factors predicting outcome. European Journal of Cancer 1999;35:1238-47.

\section{Reitzel 2010 \{published data only\}}

Heppner WL, Ji L, Reitzel LR, Reitzel L, Castro Y, CorreaFernandez $\mathrm{V}$, et al. The role of prepartum motivation in the maintenance of postpartum smoking abstinence. Health Psychology 2011;30(6):736-45.

* Reitzel LR, Vidrine JI, Businelle MS, Kendzor DE, Costello TJ, Li Y, et al. Preventing postpartum smoking relapse among diverse low-income women: a randomized clinical trial. Nicotine \& Tobacco Research 2010;12(4):326-35.

\section{Ruger 2008 \{published data only\}}

Ruger JP, Weinstein MC, Hammond SK, Kearney MH, Emmons KM. Cost-effectiveness of motivational interviewing for smoking cessation and relapse prevention among low-income pregnant women: a randomized controlled trial.. Value in Health 2008;11:191-8.

\section{Schmitz 1999 \{published data only\}}

Schmitz JM, Spiga R, Rhoades HM, Fuentes F. Smoking cessation in women with cardiac risk: a comparative study of two theoretically based therapies. Nicotine \& Tobacco Research 1999;1(1):87-94.

\section{Schroter 2006 \{published data only\}}

Schroter M, Collins SE, Frittrang T, Buchkremer G, Batra A. Randomized controlled trial of relapse prevention and a standard behavioral intervention with adult smokers. Addictive Behaviors 2006;31(7):1259-64.

\section{Secker-Walker 1995 \{published data only\}}

Secker-Walker RH, Solomon LJ, Flynn BS, Skelly JM, LePage SS, Goodwin GD, et al. Smoking relapse prevention counseling during prenatal and early postnatal care. American Journal of Preventive Medicine 1995;11:86-93.

\section{Secker-Walker 1998 \{published data only\}}

Secker-Walker RH, Solomon LJ, Flynn BS, Skelly JM, Mead PB. Smoking relapse prevention during pregnancy. A trial of coordinated advice from physicians and individual counseling. American Journal of Preventive Medicine 1998;15:25-31.

\section{Segan 2011 \{published data only\}}

Segan CJ, Borland R. Does extended telephone callback counselling prevent smoking relapse?. Health Education Research 2011;26(2):336-47.

\section{Severson 1997 \{published data only\}}

* Severson HH, Andrews JA, Lichtenstein E, Wall M, Akers L. Reducing maternal smoking and relapse: long-term evaluation of a pediatric intervention. Preventive Medicine 1997;26:120-30.

Wall MA, Severson HH, Andrews JA, Lichtenstein E, Zoref L. Pediatric office-based smoking intervention - Impact on maternal smoking and relapse. Pediatrics 1995;96:622-8.
Sheffer 2010 \{published data only\}

Sheffer CE, Stitzer M, Brandon T, Bursac Z. Effectiveness of adding relapse prevention materials to telephone counselling. Journal of Substance Abuse Treatment 2010;39:71-7.

\section{Shoptaw 2002 \{published data only\}}

Shoptaw S, Rotheram-Fuller E, Yang X, Frosch D, Nahom D, Jarvik ME, et al. Smoking cessation in methadone maintenance. Addiction 2002;97:1317-28.

\section{Simmons 2018 \{published data only\}}

Simmons VN, Sutton SK, Meltzer LR, Unrod M, Meade CD, Brandon TH. Long-term outcomes from a self-help smoking cessation randomized controlled trial. Psychology of Addictive Behaviors 2018;32(7):710-4.

Smith 2001 \{published data only\}

Smith SS, Jorenby DE, Fiore MC, Anderson JE, Mielke MM, Beach KE, et al. Strike while the iron is hot: can stepped-care treatments resurrect relapsing smokers?. Journal of Consulting and Clinical Psychology 2001;69:429-39.

\section{Stevens 1989 \{published data only\}}

* Stevens VJ, Hollis JF. Preventing smoking relapse, using an individually tailored skills-training technique. Journal of Consulting and Clinical Psychology 1989;57:420-4.

STRATUS-WW 2006 \{published and unpublished data\}

* Niaura R. Long-term maintenance of abstinence from smoking with rimonabant: results from the STRATUS Worldwide trial. 1-year efficacy/safety results. American Thoracic Society Conference.. 2005. [clinical trials.gov ID NCT00459173]

Niaura R. Long-term maintenance of abstinence from smoking with rimonabant: results from the STRATUS Worldwide trial. 6-month efficacy/safety results. American Thoracic Society Conference. 2004:POS1-054.

Sanofi Aventis. Information meeting. en.sanofi-aventis.com/Images/ en_050301_up_2004_Full_Year_Results_Analysts_Investors_meeting_in_P (accessed 23 November 2006).

\section{Tonstad 2006 \{published data only\}}

Bolin K, Mörk A-C, Wilson K. Smoking-cessation therapy using varenicline: the cost-utility of an additional 12-week course of varenicline for the maintenance of smoking abstinence. Journal of Evaluation in Clinical Practice 2009;15:478-85.

Evins AE, Hoeppner SS, Schoenfeld DA, Hoeppner BB, Cather C, Pachas GN, et al. Maintenance pharmacotherapy normalizes the relapse curve in recently abstinent tobacco smokers with schizophrenia and bipolar disorder. Schizophrenia Research 2017;183:124-9.

Hajek P, Tønneson P, Arteaga C, Russ C, Tonstad S. Varenicline in prevention of relapse to smoking: effect of quit pattern on response to extended treatment. Addiction 2009;104:1597-602.

Knight C, Howard P, Baker CL, Marton JP. The cost-effectiveness of an extended course $(12+12$ weeks) of varenicline compared with other available smoking cessation strategies in the United 
States: an extension and update to the BENESCO model. Value in Health 2010;13(2):209-14.

Knight CJ, Howard PA, Baker CL. An evaluation of the costeffectiveness of an extended course of varenicline in preventing smokers who have quit from relapsing [PSM3]. Value in Health 2007;10(6):A472.

Lee JH, Jones PG, Bybee K, O'Keefe JH. A longer course of varenicline therapy improves smoking cessation rates. Preventive Cardiology 2008;11(4):210-4.

O'Brien CP. Varenicline as maintenance therapy. Current Psychiatry Reports 2007;9(5):348-8.

* Tonstad S, Tonnesen P, Hajek P, Williams KE, Billing CB, Reeves KR. Effect of maintenance therapy with varenicline on smoking cessation: a randomized controlled trial. JAMA 2006;296:64-71.

\section{Unrod 2016 \{published data only\}}

Unrod M, Simmons VN, Sutton SK, Cummings KM, Celestino P, Craig BM, et al. Relapse-prevention booklets as an adjunct to a tobacco quitline: a randomized controlled effectiveness trial. Nicotine \& Tobacco Research 2016;18(3):298-305.

Van't Hof 2000 \{published data only\}

Van't Hof SM, Wall MA, Dowler DW, Stark MJ. Randomised controlled trial of a postpartum relapse prevention intervention. Tobacco Control 2000;9 Suppl 3:III64-6.

\section{Van Osch 2008 \{published data only\}}

Van Osch L, Lechner L, Reubsaet A, Wigger S, De Vries H. Relapse prevention in a national smoking cessation contest: effects of coping planning. British Journal of Health Psychology 13;2008:525-35.

\section{Veldheer 2018 \{published data only\}}

Veldheer S, Hrabovsky S, Yingst J, Sciamanna C, Berg A, Foulds $\mathrm{J}$. The use of self-directed relapse prevention booklets to assist in maintaining abstinence after a 6 -week group smoking cessation treatment program: a randomized controlled trial. Health Education \& Behavior 2018;45(2):190-7.

Wetter 2011 \{published data only\}

Wetter D, McClure J. A randomized clinical trial of a palmtop computer-delivered treatment for smoking relapse prevention among women. Psychology of Addictive Behaviours 2011;25(2):365-71

\section{References to studies excluded from this review \\ ACTRN12618000408280 \{published data only\}}

ACTRN12618000408280. Cessation and Relapse Prevention (CARP) Trial: nicotine vaporisers compared to standard nicotine replacement therapy for smoking cessation among people with co-morbidities. www.who.int/trialsearch/Trial2.aspx? TrialID=ACTRN12618000408280 (first received 21 March 2018).

\section{Adams 2011 \{published data only\}}

Adams KK, Merritt TA. Prevention of postpartum smoking relapse in mothers to prevent infant exposure to second-hand smoke. Journal of Investigative Medicine 2011;59:102.

\section{Allen 2007 \{published data only\}}

Allen S, Bade T, Hatsukami D. Smoking relapse in women: effect of menstrual phase. SYM 10B Society for Research on Nicotine and Tobacco 13th Annual Meeting; 2007 February 21-24; Austin, TX. 2007.

\section{Alterman 2001 \{published data only\}}

Alterman Al, Gariti P, Mulvaney F. Short- and long-term smoking cessation for three levels of intensity of behavioral treatment. Psychology of Addictive Behaviors 2001;15(3):261-4.

\section{Berndt 2012 \{published data only\}}

Berndt N, Bolman C, Lechner L, Mudde A, Verheugt FW, De Vries $\mathrm{H}$. Effectiveness of two intensive treatment methods for smoking cessation and relapse prevention in patients with coronary heart disease: study protocol and baseline description. BMC Cardiovascular Disorders 2012;12:33.

\section{Bottausci 1995 \{published data only\}}

Bottausci AJ. An experimental study of cue exposure as a relapse prevention technique in smoking cessation maintenance. Masters Abstracts International 1995;32(3):1063.

\section{Brown 2001 \{published data only\}}

Brown RA, Kahler CW, Niaura R, Abrams DB, Sales SD, Ramsey SE, et al. Cognitive-behavioral treatment for depression in smoking cessation. Journal of Consulting and Clinical Psychology 2001;69:471-80.

\section{Carmody 1988 \{published data only\}}

Carmody TP, Loew DE, Hall RG, Breckenridge JS. Nicotine polacrilex: clinic-based strategies with chronically ill smokers. Special Issue. Pharmacological adjuncts and nutritional supplements in the treatment of drug dependence. Journal of Psychoactive Drugs 1988;20(3):269-74.

\section{Carmody 2017 \{published data only\}}

Carmody TP, Duncan CL, Solkowitz SN, Huggins J, Simon JA. Hypnosis for smoking relapse prevention: a randomized trial. American Journal of Clinical Hypnosis 2017;60(2):159-71.

\section{Cather 2013 \{published data only\}}

Cather C, Dyer MA, Burrell HA, Hoeppner B, Goff DC, Evins AE. An open trial of relapse prevention therapy for smokers with schizophrenia. Journal of Dual Diagnosis 2013;9(1):87-93.

\section{Cinciripini 2000 \{published data only\}}

Cinciripini PM, McClure JB, Wetter DW, Perry J, Blalock JA, Cinciripini LG, et al. An evaluation of videotaped vignettes for smoking cessation and relapse prevention during pregnancy: the very important pregnant smokers (VIPS) program. Tobacco Control 2000;9 Suppl:III, 61-3.

\section{Copeland 2006 \{published data only\}}

Copeland AL, Martin PD, Geiselman PJ, Rash CJ, Kendzor DE. Smoking cessation for weight-concerned women: group vs. 
individually tailored, dietary, and weight-control follow-up sessions. Addictive Behaviors 2006;31(1):115-27.

Davis 1995 \{published data only\}

Davis MJ, Baker LJV. Smoking cessation: the use of a choice of strategies to aid cessation and maintenance. Irish Journal of Psychology 1995;16(2):150-61.

\section{DiSantis 2010 \{published data only\}}

DiSantis KI, Collins BN, McCoy AC. Associations among breastfeeding, smoking relapse, and prenatal factors in a brief postpartum smoking intervention. Acta Obstetricia Et Gynecologica Scandinavica 2010;89(4):582-6.

Dooley 1992 \{published data only\}

Dooley RT, Halford WK. A comparison of relapse prevention with nicotine gum or nicotine fading in modification of smoking. Australian Psychology 1992;27(3):186-91.

\section{Dubren 1977 \{published data only\}}

Dubren R. Self-reinforcement by recorded telephone messages to maintain non-smoking behavior. Journal of Consulting and Clinical Psychology 1977;45:358-60.

\section{Dunphy 2000 \{published data only\}}

Dunphy PM. Using an Empowerment and Education Intervention to Prevent Smoking Relapse in the Early Postpartum Period [dissertation]. Philadelphia: University of Pennsylvania, 2000.

\section{Elfeddali 2012 \{published data only\}}

Elfeddali I, Bolman C, Candel MJ, Wiers RW, De Vries H. Preventing smoking relapse via web-based computertailored feedback: a randomized controlled trial. Journal of Medical Internet Research 2012;14(4):e109.

\section{Evins 2011 \{published data only\}}

Evins AE, Pachas G, Mischoulon D, Urbanoski K, Carlini S, Sousa J, et al. A double-blind, placebo-controlled trial of the NMDA glycine site antagonist, GW468816, for prevention of relapse to smoking in females. Journal of Clinical Psychopharmacology 2011;31(5):597-602.

\section{Feeney 2001 \{published data only\}}

Feeney GF, McPherson A, Connor JP, McAlister A, Young MR, Garrahy P. Randomized controlled trial of two cigarette quit programmes in coronary care patients after acute myocardial infarction. Internal Medicine Journal 2001;31(8):470-5.

\section{French 2007 \{published data only\}}

French GM, Groner JA, Wewers ME, Ahijevych K. Staying smoke free: an intervention to prevent postpartum relapse. Nicotine \& Tobacco Research 2007;9(6):663-70.

\section{French 2018 \{published data only\}}

French KM, Gonzalez SZ, Sherman SE, Link AR, Malik SZ, Tseng C-H, et al. Financial IncEntives for Smoking TreAtment: protocol of the FIESTA trial and FIESTA oral microbiome substudy. Trials 2018;19(1):646.

\section{Froelicher 2000 \{published data only\}}

Froelicher ES, Christopherson DJ. Women's Initiative for NonSmoking (WINS) I: design and methods. Heart \& Lung 2000;29(6):429-37.

\section{Garvey 2012 \{published data only\}}

Garvey AJ, Kalman D, Hoskinson RA Jr, Kinnunen T, Wadler BM, Thomson CC, et al. Front-loaded versus weekly counseling for treatment of tobacco addiction. Nicotine \& Tobacco Research 2012;14(5):578-85.

\section{George 2000 \{published data only\}}

George TP, Ziedonis DM, Feingold A, Pepper WT, Satterburg CA, Winkel J, et al. Nicotine transdermal patch and atypical antipsychotic medications for smoking cessation in schizophrenia. American Journal of Psychiatry 2000;157(11):1835-42.

\section{Goldstein 1989 \{published data only\}}

* Goldstein MG, Niaura R, Follick MJ, Abrams DB. Effects of behavioral skills training and schedule of nicotine gum administration on smoking cessation. American Journal of Psychiatry 1989;146:56-60.

\section{Gruder 1993 \{published data only\}}

* Gruder CL, Mermelstein RJ, Kirkendol S, Hedeker D, Wong SC, Schreckengost J, et al. Effects of social support and relapse prevention training as adjuncts to a televised smokingcessation intervention. Journal of Consulting and Clinical Psychology 1993;61(1):113-20.

Warnecke RB, Flay BR, Kviz FJ, Gruder CL, Langenberg P, Crittenden KS, et al. Characteristics of participants in a televised smoking cessation intervention. Preventive Medicine 1991;20:389-403.

\section{Hall 1994 \{published data only\}}

Hall SM, Munoz RF, Reus VI. Cognitive-behavioral intervention increases abstinence rates for depressive-history smokers. Journal of Consulting and Clinical Psychology 1994;62(1):141-6.

Hall 1996 \{published data only\}

* Hall SM, Munoz RF, Reus VI, Sees KL, Duncan C, Humfleet GL, et al. Mood management and nicotine gum in smoking treatment - a therapeutic contact and placebo-controlled study. Journal of Consulting and Clinical Psychology 1996;64:1003-9.

Hall 1998 \{published data only\}

* Hall SM, Reus VI, Munoz RF, Sees KL, Humfleet G, Hartz DT, et al. Nortriptyline and cognitive-behavioral therapy in the treatment of cigarette smoking. Archives of General Psychiatry 1998;55:683-90.

Hall SM, Reus VI, Munoz RF, Sees KL, Humfleet GL, Frederick S. Nortriptyline and cognitive-behavioral treatment of cigarette smoking. Proceedings of the CPDD Annual Meeting; San Juan, Puerto Rico. 1996; Vol. 52.

\section{Hall 2011 \{published data only\}}

* Hall SM, Humfleet GL, Muñoz RF, Reus VI, Prochaska JJ, Robbins JA. Using extended cognitive behavioral treatment and 
medication to treat dependent smokers. American Journal of Public Health 2011;101(12):2349-56.

Prochaska JJ, Hall SM, Humfleet G, Munoz RF, Reus V, Gorecki J, et al. Physical activity as a strategy for maintaining tobacco abstinence: a randomized trial. Preventive Medicine 2008;47(2):215-20.

\section{Hassandra 2017 \{published data only\}}

* Hassandra M, Lintunen T, Hagger MS, Heikkinen R, Vanhala M, Kettunen T. An mHealth app for supporting quitters to manage cigarette cravings with short bouts of physical activity: a randomized pilot feasibility and acceptability study. JMIR mHealth and uHealth 2017;5(5):e74.

Hassandra M, Lintunen T, Kettunen T, Vanhala M, Toivonen HM, Kinnunen K, et al. Effectiveness of a mobile phone app for adults that uses physical activity as a tool to manage cigarette craving after smoking cessation: a study protocol for a randomized controlled trial. JMIR Research Protocols 2015;4(4):e125.

\section{Juliano 2006 \{published data only\}}

Juliano LM, Houtsmuller EJ, Stitzer ML. A preliminary investigation of rapid smoking as a lapse-responsive treatment for tobacco dependence. Experimental \& Clinical Psychopharmacology 2006;14:429-38.

\section{Klesges 1987 \{published data only\}}

Klesges R, Glasgow RE, Klesges L, Morray K, Quale R. Competition and relapse prevention training in worksite smoking modification. Health Education Research 1987;2:5-14.

\section{Lando 1997 \{published data only\}}

* Lando HA, Rolnick S, Klevan D, Roski J, Cherney L, Lauger G. Telephone support as an adjunct to transdermal nicotine in smoking cessation. American Journal of Public Health 1997;87:1670-4.

Rolnick SJ, Klevan D, Cherney L, Lando HA. Nicotine replacement therapy in a group model HMO. HMO Practice 1997;11:34-7.

\section{Laude 2017 \{published data only\}}

Laude JR, Bailey SR, Crew E, Varady A, Lembke A, McFall D, et al. Extended treatment for cigarette smoking cessation: a randomized control trial. Addiction 2017;112(8):1451-9.

\section{Macleod 2003 \{published data only\}}

Macleod ZR, Charles MA, Arnaldi VC, Adams IM. Telephone counselling as an adjunct to nicotine patches in smoking cessation: a randomised controlled trial. Medical Journal of Australia 2003;179:349-52.

\section{Miller 1997 \{published data only\}}

* Miller NH, Smith PM, DeBusk RF, Sobel DS, Taylor CB. Smoking cessation in hospitalized patients - results of a randomized trial. Archives of Internal Medicine 1997;157:409-15.

Taylor CB, Miller NH, Herman S, Smith PM, Sobel D, Fisher L, et al. A nurse-managed smoking cessation program for hospitalized smokers. American Journal of Public Health 1996;86:1557-60.

NCT00218465 \{published data only\}

NCT00218465. Effectiveness of GW468816, an NMDA glycine site antagonist, for prevention of relapse to smoking. clinicaltrials.gov/show/NCT00218465 (date first received: 22 September 2005).

NCT00621777 \{published data only\}

NCT00621777. A study of varenicline for prevention of relapse to smoking in patients with schizophrenia. clinicaltrials.gov/ct2/ show/nct00621777 (date first received: 22 February 2008).

\section{NCT01131156 \{published data only\}}

NCT01131156. Prevention of postpartum smoking relapse in mothers of infants in the neonatal intensive care unit (NICU). clinicaltrials.gov/ct2/show/NCT01131156 (date first received: 26 May 2010).

\section{NCT02888444 \{published data only\}}

NCT02888444. Smoking relapse prevention among COPD ex-smokers. clinicaltrials.gov/show/NCT02888444 (date first received: 5 September 2016).

\section{NCT02968095 \{published data only\}}

NCT02968095. Text message support to prevent smoking relapse. clinicaltrials.gov/show/NCT02968095 (date first received: 18 November 2016).

\section{NCT03113370 \{published data only\}}

NCT03113370. Preventing tobacco relapse with omega-3s trial. clinicaltrials.gov/show/NCT03113370 (first received 13 April 2017).

\section{NCT03262662 \{published data only\}}

NCT03262662. EVarQuit: extended pre-quit varenicline to assist in quitting smoking. clinicaltrials.gov/show/NCT03262662 (first received 25 August 2017).

\section{NCT03690596 \{published data only\}}

NCT03690596. Smoking relapse prevention via just-in-timeadaptive interventions. clinicaltrials.gov/show/NCT03690596 (first received 1 October 2018).

\section{NCT03930329 \{published data only\}}

NCT03930329. Mindfulness-based treatment to prevent smoking relapse. clinicaltrials.gov/show/NCT03930329 (first received 29 April 2019).

\section{Phillips 2012 \{published data only\}}

Phillips RM, Merritt TA, Goldstein MR, Deming DD, Slater LE, Angeles DM. Supporting mother-infant bonding increases the duration of breastfeeding in mothers with newborns in the neonatal intensive care unit. Breastfeeding Medicine 2011;6:S4.

* Phillips RM, Merritt TA, Goldstein MR, Deming DD, Slater LE, Angeles DM. Prevention of postpartum smoking relapse in mothers of infants in the neonatal intensive care unit. Journal of Perinatology 2012;32(5):374-80. 
Reid 1999 \{published data only\}

Reid RD, Pipe A, Dafoe WA. Is telephone counselling a useful addition to physician advice and nicotine replacement therapy in helping patients to stop smoking? A randomized controlled trial. Canadian Medical Association Journal 1999;160:1577-81.

Schlam 2016 \{published data only\}

Schlam TR, Fiore MC, Smith SS, Fraser D, Bolt DM, Collins LM, et al. Comparative effectiveness of intervention components for producing long-term abstinence from smoking: a factorial screening experiment. Addiction 2016;111(1):142-55. [DOI: 10.1111/add.13153]

\section{Schnoll 2015 \{published data only\}}

Schnoll RA, Goelz PM, Veluz-Wilkins A, Blazekovic S, Powers $\mathrm{L}$, Leone FT, et al. Long-term nicotine replacement therapy: a randomized clinical trial. JAMA Internal Medicine 2015;175(4):504-11.

\section{Snuggs 2012 \{published data only\}}

Snuggs S, McRobbie H, Myers K, Schmocker F, Goddard J, Hajek P. Using text messaging to prevent relapse to smoking: intervention development, practicability and client reactions. Addiction 2012;107(Suppl 2):39-44.

\section{Solomon 2000 \{published data only\}}

Solomon LJ, Scharoun GM, Flynn BS, Secker-Walker RH, Sepinwall D. Free nicotine patches plus proactive telephone peer support to help low-income women stop smoking. Preventive Medicine 2000;31:68-74.

\section{Storro 2008 \{published data only\}}

Storro O, Oien T, Johnsen R. Preventing relapse of smoking among postnatal women and their partners in primary care: a controlled birth cohort intervention study. Allergy 2008;63(Suppl 88):483.

\section{Tonstad 2013 \{published data only\}}

Tonstad S, Heggen E, Giljam H, Lagerbäck PA, Tønnesen P, Wikingsson LD, et al. Niccine ${ }^{\circledR}$, a nicotine vaccine for relapse prevention: a phase II, randomized, placebo-controlled, multicenter clinical trial. Nicotine \& Tobacco Research 2013 [Epub ahead of print].

\section{Yoon 2009 \{published data only\}}

Yoon JH, Higgins ST, Bradstreet MP, Badger GJ, Thomas CS. Changes in the relative reinforcing effects of cigarette smoking as a function of initial abstinence. Psychopharmacology 2009;205(2):305-18.

\section{Zelman 1992 \{published data only\}}

Zelman DC, Brandon TH, Jorenby DE, Baker TB. Measures of affect and nicotine dependence predict differential response to smoking cessation treatments. Journal of Consulting and Clinical Psychology 1992;60:943-52.

\section{References to ongoing studies}

\section{ACTRN12617000514303 \{published data only\}}

ACTRN12617000514303. Real-time video counselling for smoking cessation in regional and remote areas. www.anzctr.org.au/ACTRN12617000514303.aspx (first received 7 April 2017).

\section{Bock 2014 \{published data only\}}

Bock BC, Rosen RK, Fava JL, Gaskins RB, Jennings E, Thind H, et al. Testing the efficacy of yoga as a complementary therapy for smoking cessation: design and methods of the BreathEasy trial. Contemporary Clinical Trials 2014; Vol. 38, issue 2:321-32.

\section{Brandon 2014 \{published data only\}}

Brandon TH, Klesges RC, Ebbert JO, Talcott GW, Thomas F, Leroy $\mathrm{K}$, et al. Preventing smoking initiation or relapse following 8.5 weeks of involuntary smoking abstinence in basic military training: trial design, interventions, and baseline data. Contemporary Clinical Trials 2014; Vol. 38, issue 1:28-36.

Diaz 2016 \{published data only\}

Diaz DB, Brandon TH, Sutton SK, Meltzer LR, Hoehn HJ, Meade $C D$, et al. Smoking relapse-prevention intervention for cancer patients: study design and baseline data from the surviving SmokeFree randomized controlled trial. Contemporary Clinical Trials 2016; Vol. 50:84-9.

Fallgatter 2015 \{published data only\}

Fallgatter AJ, Dieler A, Herrmann MJ, Dresler T. Non-invasive brain stimulation - a modern approach to improved therapy of nicotin addiction?. Brain Stimulation 2015;8(2):429.

\section{Garvey 2012a \{published data only\}}

Garvey AJ, Kalman D, Hoskinson RA, Kinnunen T, Armour CD, Copp S, et al. Effects of extended-duration counseling vs. shorter-duration counseling after 1.5 years of follow-up (POS4-49). Society for Research on Nicotine and Tobacco 18th Annual Meeting; 2012 March 13-16. 2012:139.

\section{Giovancarli 2016 \{published data only\}}

Giovancarli C, Malbos E, Baumstarck K, Parola N, Pelissier MF, Lancon $C$, et al. Virtual reality cue exposure for the relapse prevention of tobacco consumption: a study protocol for a randomized controlled trial. Trials 2016;17(1):96

ISRCTN11111428 \{published data only\}

ISRCTN11111428. Relapse prevention trial. www.isrctn.com/ ISRCTNISRCTN11111428 (first received 27 November 2016).

\section{Meghea 2015 \{published data only\}}

* Meghea Cl, Brinzaniuc A, Mihu D, luhas $\mathrm{Cl}$, Stamatian F, Caracostea $\mathrm{G}$, et al. A couple-focused intervention to prevent postnatal smoking relapse: PRISM study design. Contemporary Clinical Trials 2015;41:273-9.

Meghea Cl, Brinzaniuc A, Rus IA, Chereches RM, Mihu D, luhas Cl, et al. Characteristics of Romanian women who enrolled in a postpartum tobacco smoking relapse prevention trial. Public Health 2018;154:98-101. 
NCT01162239 \{published data only\}

NCT01162239. Maintaining nonsmoking. clinicaltrials.gov/ show/NCT01162239 (first received 14 July 2010).

NCT01305447 \{published data only\}

NCT01305447. Getting physical on cigarettes

- smoking cessation \& relapse prevention. clinicaltrials.gov/ct2/ show/NCT01305447 (first received 28 February 2011).

NCT01756885 \{published data only\}

NCT01756885. Extended duration varenicline for smoking among cancer patients: a clinical trial. clinicaltrials.gov/show/ NCT01756885 (first received 28 December 2012).

\section{NCT02271919 \{published data only\}}

NCT02271919. Varenicline and combined nicotine replacement therapy (NRT) for initial smoking cessation and rescue treatment in smokers: a randomized pilot trial. clinicaltrials.gov/show/NCT02271919 (first received 22 October 2014).

\section{NCT02327104 \{published data only\}}

NCT02327104. Effectiveness of mindfulness based relapse prevention for tobacco dependents. clinicaltrials.gov/ct2/show/ NCT02327104 (first received 30 December 2014).

\section{NCT02823028 \{published data only\}}

NCT02823028. Twitter-enabled mobile messaging for smoking relapse prevention (Tweet2Quit). clinicaltrials.gov/ct2/show/ NCT02823028 (first received 6 July 2016).

\section{NCT03365362 \{published data only\}}

NCT03365362. A trial of directly observed and long-term varenicline. clinicaltrials.gov/ct2/show/NCT03365362 (first received 7 December 2017).

\section{NCT03673228 \{published data only\}}

NCT03673228. Preventing smoking relapse after total joint replacement surgery. clinicaltrials.gov/ct2/show/nct03673228 (first received 17 September 2018)

NCT03760224 \{published data only\}

NCT03760224. Effectiveness of WhatsApp online group discussion for smoking relapse prevention. clinicaltrials.gov/ ct2/show/nct03760224 (first received 30 November 2018).

\section{Additional references}

\section{Agboola 2010}

Agboola S, McNeill A, Coleman T, Leonardi Bee J. A systematic review of the effectiveness of smoking relapse prevention interventions for abstinent smokers. Addiction 2010;105(8):1362-80.

\section{Cahill 2013}

Cahill K, Stevens S, Perera R, Lancaster T. Pharmacological interventions for smoking cessation: an overview and network meta-analysis. Cochrane Database of Systematic Reviews 2013, Issue 5. [DOI: 10.1002/14651858.CD009329.pub2]

\section{Cahill 2016}

Cahill K, Lindson-Hawley N, Thomas KH, Fanshaw TR, Lancaster T. Nicotine receptor partial agonists for smoking cessation. Cochrane Database of Systematic Reviews 2016, Issue 5. [DOI: 10.1002/14651858.CD006103.pub7]

\section{Coleman 2010}

Coleman T, Agboola S, Leonardi-

Bee J, Taylor M, McEwen A, McNeill A.

Relapse prevention in UK Stop Smoking Services: current practice, systema effectiveness analysis. Health Technology Assessment 2010;14(49):1-152.

\section{Edwards 1999}

Edwards CC, Woodruff SI, Conway TL. Operation Stay Quit: preventing smoking relapse among US Navy women. American Journal of Health Behavior 1999;23(5):352-5.

\section{Hajek 1994}

Hajek P. Appraising the efficacy of psychological treatments for smokers. Journal of Smoking-Related Disorders 1994;5:101-7.

\section{Hajek 2001a}

Hajek P, Stead LF. Aversive smoking for smoking cessation. Cochrane Database of Systematic Reviews 2001, Issue 3. [DOI: 10.1002/14651858.CD000546.pub2]

\section{Hartmann-Boyce 2018}

Hartmann-Boyce J, Chepkin SC, Ye W, Bullen C, Lancaster T. Nicotine replacement therapy versus control for smoking cessation. Cochrane Database of Systematic Reviews 2018, Issue 5. [DOI: 10.1002/14651858.CD000146.pub5]

\section{Higgins 2003}

Higgins JP, Thompson SG, Deeks JJ, Altman DG. Measuring inconsistency in meta-analyses. BMJ 2003;7414:557-60.

\section{Hughes 2014}

Hughes JR, Stead LF, Hartmann-Boyce J, Cahill K, Lancaster T. Antidepressants for smoking cessation. Cochrane Database of Systematic Reviews 2014, Issue 1. [DOI: 10.1002/14651858.CD000031.pub4]

\section{Lancaster 2017}

Lancaster T, Stead LF. Individual behavioural counselling for smoking cessation. Cochrane Database of Systematic Reviews 2017, Issue 3. [DOI: 10.1002/14651858.CD001292.pub3]

\section{Lindson 2019}

Lindson N, Chepkin SC, Ye W, Fanshawe TR, Bullen C, HartmannBoyce J. Different doses, durations and modes of delivery of nicotine replacement therapy for smoking cessation. Cochrane Database of Systematic Reviews 2019, Issue 4. [DOI: 10.1002/14651858.CD013308]

\section{Marlatt 1985}

Marlatt A, Gordon J. Relapse Prevention. New York: Guilford Press, 1985. 


\section{Marlatt 2008}

Marlatt GA, Donovan DM, editors. Relapse Prevention: Maintenance Strategies in the Treatment of Addictive Behaviours. 2nd Edition. New York: Guilford Press, 2008.

\section{Notley 2019}

Notley C, Gentry S, Livingstone-Banks J, Bauld L, Perera R, Hartmann-Boyce J. Incentives for smoking cessation. Cochrane Database of Systematic Reviews 2019, Issue 7. [DOI: 10.1002/14651858.CD004307.pub6]

\section{Ossip-Klein 1986}

Ossip-Klein DJ, Bigelow G, Parker SR, Curry S, Hall S, Kirkland S. Classification and assessment of smoking behavior. Health Psychology 1986;5 Suppl:3-11.

\section{Rigotti 2012}

Rigotti NA, Munafo MR, Stead LF. Interventions for smoking cessation in hospitalised patients. Cochrane Database of Systematic Reviews 2012, Issue 5. [DOI: 10.1002/14651858.CD001837.pub3]

\section{Segan 2008}

Segan CJ, Borland R, Hannan A, Stillman S. The challenge of embracing a smoke-free lifestyle: a neglected area in smoking cessation programs. Health Education Research 2008;23(1):1-9. [DOI: 10.1093/her/cyl157]

\section{Stead 2017}

Stead LF, Carroll AJ, Lancaster T. Group behaviour therapy programmes for smoking cessation. Cochrane Database of Systematic Reviews 2017, Issue 3. [DOI: 10.1002/14651858.CD001007.pub3]

\section{CHARACTERISTICS OF STUDIES}

Characteristics of included studies [ordered by study ID]

\section{Ussher 2012}

Ussher MH, Taylor AH, Faulkner G. Exercise interventions for smoking cessation. Cochrane Database of Systematic Reviews 2012, Issue 1. [DOI: 10.1002/14651858.CD002295.pub4]

\section{References to other published versions of this review \\ Hajek 2005}

Hajek P, Stead LF, West R, Jarvis M, Lancaster T. Relapse prevention interventions for smoking cessation. Cochrane Database of Systematic Reviews 2005, Issue 1. [DOI: 10.1002/14651858.CD003999.pub2]

\section{Hajek 2009}

Hajek P, Stead LF, West R, Jarvis M, Lancaster T. Relapse prevention interventions for smoking cessation. Cochrane Database of Systematic Reviews 2009, Issue 1. [DOI: 10.1002/14651858.CD003999.pub3]

\section{Hajek 2013}

Hajek P, Stead LF, West R, Jarvis M, Hartmann-Boyce J, Lancaster T. Relapse prevention interventions for smoking cessation. Cochrane Database of Systematic Reviews 2013, Issue 8. [DOI: 10.1002/14651858.CD003999.pub4]

\section{Livingstone-Banks 2019}

Livingstone-Banks J, Norris E, Hartmann-Boyce J, West R, Jarvis M, Hajek P. Relapse prevention interventions for smoking cessation. Cochrane Database of Systematic Reviews 2019, Issue 2. [DOI: 10.1002/14651858.CD003999.pub5]

* Indicates the major publication for the study

Becona 1997

$\begin{array}{ll}\text { Methods } & \text { Setting: cessation clinic, Spain } \\ & \text { Recruitment: community volunteers } \\ & \text { Group size: } 36 \text { to } 40\end{array}$

Participants 76 smokers, $\geq 10$ cigs/day (excluded an untreated control group of 40 , not randomly selected). $51 \%$ female, average age 34 , average cigs/day 28

Interventions Both conditions received 8 weekly sessions in groups of 36 to 40, duration not specified, TQD week 4, 2 experienced therapists

1. Standard programme: motivational contract, nicotine fading, stimulus control

2. Relapse prevention. As 1 plus problem solving

$\begin{array}{ll}\text { Outcomes } & \text { Abstinence at } 12 \text { months (definition not specified) } \\ \text { Validation: } \mathrm{CO}<8 \mathrm{ppm} \text { during therapy, informants during follow-up }\end{array}$

Notes

\section{Risk of bias}


Becona 1997 (Continued)

\begin{tabular}{lll} 
Bias & Authors' judgement & Support for judgement \\
\hline $\begin{array}{l}\text { Random sequence genera- } \\
\text { tion (selection bias) }\end{array}$ & Unclear risk & Randomisation method not described \\
\hline $\begin{array}{l}\text { Allocation concealment } \\
\text { (selection bias) }\end{array}$ & Unclear risk & No information given \\
\hline
\end{tabular}

Blinding of participants $\quad$ Unclear risk
and personnel (perfor-
mance bias)
All outcomes

\begin{tabular}{lll}
\hline $\begin{array}{l}\text { Blinding of outcome as- } \\
\text { sessment (detection bias) }\end{array}$ & Low risk & \\
All outcomes & & \\
\hline $\begin{array}{l}\text { Incomplete outcome data } \\
\text { (attrition bias) }\end{array}$ & Low risk & All randomly assigned participants included in ITT analysis \\
All outcomes & & \\
\hline
\end{tabular}

\section{Blebil 2014}

\begin{tabular}{ll}
\hline Methods & Setting: quit smoking clinics, Malaysia \\
& Recruitment: eligible clinic attendees \\
\hline Participants & 231 smokers, 120 in phone support arm and 111 in control \\
& $96.1 \%$ male, average age: 48 , average cigarettes/day: 14 \\
\hline Interventions & $\begin{array}{l}\text { 1. Relapse prevention: as control with an additional phone call after each visit in month } 1 \text { providing in- } \\
\text { formation, encouragement, etc. } \\
\text { 2. Control: attend quit smoking clinic } 4 \text { times in month } 1,2 \text { times in month } 2 \text { with a phone call after } \\
\text { each visit, and } 1 \text { visit with } 2 \text { phone calls in month 3, self-help materials throughout }\end{array}$ \\
\hline Outcomes & $\begin{array}{l}\text { Point prevalence abstinence at } 6 \text { months } \\
\text { Validation: } \text { CO } \geq 7 \text { ppm at } 6 \text { months }\end{array}$ \\
\hline Notes & $\begin{array}{l}\text { Fupouts counted as continuing smokers } \\
\text { Declaration of Interests: "The authors declare that they have no competing interests." }\end{array}$ \\
\hline
\end{tabular}

\section{Risk of bias}

\begin{tabular}{lll}
\hline Bias & Authors' judgement & Support for judgement \\
\hline $\begin{array}{l}\text { Random sequence genera- } \\
\text { tion (selection bias) }\end{array}$ & Low risk & Assignments created by Urn design \\
\hline $\begin{array}{l}\text { Allocation concealment } \\
\text { (selection bias) }\end{array}$ & Unclear risk & No information on concealment \\
\hline
\end{tabular}


Blebil 2014 (Continued)
Blinding of participants
Unclear risk
No information on blinding and personnel (perfor- mance bias)
All outcomes

\begin{tabular}{lll}
\hline $\begin{array}{l}\text { Blinding of outcome as- } \\
\text { sessment (detection bias) }\end{array}$ & Low risk & \\
All outcomes & \\
\hline $\begin{array}{l}\text { Incomplete outcome data } \\
\text { (attrition bias) }\end{array}$ & Low risk & Low dropout rate at 6 months \\
All outcomes & \\
\hline
\end{tabular}

\section{Blyth 2015}

\begin{tabular}{|c|c|}
\hline Methods & $\begin{array}{l}\text { Setting: participants' own homes, UK } \\
\text { Recruitment: short-term quitters recruited from NHS Stop Smoking Clinics }\end{array}$ \\
\hline Participants & $\begin{array}{l}1404 \text { ex-smokers (4-week abstinence), } 702 \text { in intervention group and } 702 \text { in control } \\
47.3 \% \text { male, average age } 47 \text {, average cigarettes per day } 20\end{array}$ \\
\hline Interventions & $\begin{array}{l}\text { 1. Relapse prevention: eight 'Forever Free' self-help booklets by post } \\
\text { 2. Control: single leaflet 'Learning to Stay Stopped' routinely given to NHS patients }\end{array}$ \\
\hline Outcomes & $\begin{array}{l}\text { Continuous abstinence from } 2 \text { to } 12 \text { months } \\
\text { Validation: } \mathrm{CO}<10 \mathrm{ppm} \text { at } 12 \text { months }\end{array}$ \\
\hline Notes & $\begin{array}{l}\text { Funding: "This project was funded by the National Institute for Health Research (NIHR) Health Technol- } \\
\text { ogy Assessment programme" } \\
\text { Declaration of Interest: "Paul Aveyard has done ad hoc consultancy and research for the pharmaceuti- } \\
\text { cal industry on smoking cessation." }\end{array}$ \\
\hline
\end{tabular}

\section{Risk of bias}

\begin{tabular}{lll}
\hline Bias & Authors' judgement & Support for judgement \\
\hline $\begin{array}{l}\text { Random sequence genera- } \\
\text { tion (selection bias) }\end{array}$ & Low risk & Simple randomisation method used \\
\hline $\begin{array}{l}\text { Allocation concealment } \\
\text { (selection bias) }\end{array}$ & Unclear risk & $\begin{array}{l}\text { Quote: "The participant allocation was 'concealed' because the recruitment of } \\
\text { quitters occurred before the random allocation." However, it was unclear how } \\
\text { this would achieve allocation concealment. }\end{array}$ \\
\hline $\begin{array}{l}\text { Blinding of participants } \\
\begin{array}{l}\text { and personnel (perfor- } \\
\text { mance bias) }\end{array}\end{array}$ & Low risk & $\begin{array}{l}\text { Blinding not performed, but face-to-face contact was the same between the } \\
\text { two groups, so performance bias unlikely. }\end{array}$ \\
\hline $\begin{array}{l}\text { Blinding of outcome as- } \\
\text { sessment (detection bias) } \\
\text { All outcomes }\end{array}$ & Low risk & Biochemically validated abstinence \\
\hline
\end{tabular}


Blyth 2015 (Continued)

Incomplete outcome data Low risk Follow-up rates similar in both groups (intervention $=87 \%$, control $=85 \%$ ) (attrition bias)

All outcomes

\section{Borland 2004}

\begin{tabular}{ll}
\hline Methods & $\begin{array}{l}\text { Setting: Quitline, Australia } \\
\text { Recruitment: volunteers calling a quitline to request self help materials }\end{array}$ \\
\hline Participants & $\begin{array}{l}215 \text { smokers who had quit at time of recruitment (other participants not included in this review) } \\
\text { Demographics for all participants: } 54 \% \text { female, approximately } 47 \%<30 \text { years, average cigs/day } 21 \\
63 \% \text { had quit in previous week }\end{array}$ \\
\hline Interventions & $\begin{array}{l}\text { All participants received a quit pack at the time of first contact with the quitline, } 1 \text { to } 2 \text { days before re- } \\
\text { cruitment }\end{array}$ \\
$\begin{array}{l}\text { 1. Series of tailored advice letters based on standardised telephone assessment. } 2 \text { to } 3 \text { pages, tailored } \\
\text { in part by stage of change, timing varied }\end{array}$ \\
2. No further intervention
\end{tabular}

\begin{tabular}{ll}
\hline Outcomes & $\begin{array}{l}\text { Abstinence at } 12 \text { months, sustained for } 6 \text { months } \\
\text { Validation: none }\end{array}$
\end{tabular}

Validation: none

Notes

\section{Risk of bias}

\begin{tabular}{|c|c|c|}
\hline Bias & Authors' judgement & Support for judgement \\
\hline $\begin{array}{l}\text { Random sequence genera- } \\
\text { tion (selection bias) }\end{array}$ & Low risk & Computer-generated numbers with even numbers allocated to intervention \\
\hline $\begin{array}{l}\text { Allocation concealment } \\
\text { (selection bias) }\end{array}$ & Low risk & ID number generated after agreement to participate \\
\hline $\begin{array}{l}\text { Blinding of participants } \\
\text { and personnel (perfor- } \\
\text { mance bias) } \\
\text { All outcomes }\end{array}$ & Low risk & $\begin{array}{l}\text { Blinding not possible because of nature of the intervention, but "participants } \\
\text { in each condition [did] not know about the other condition unless they specifi- } \\
\text { cally asked ... (none did)" }\end{array}$ \\
\hline $\begin{array}{l}\text { Blinding of outcome as- } \\
\text { sessment (detection bias) } \\
\text { All outcomes }\end{array}$ & Low risk & $\begin{array}{l}\text { No blinding or validation of smoking status, but because of low-contact nature } \\
\text { of intervention, differential misreport of smoking unlikely }\end{array}$ \\
\hline $\begin{array}{l}\text { Incomplete outcome data } \\
\text { (attrition bias) } \\
\text { All outcomes }\end{array}$ & Low risk & Losses to follow-up $23 \%$ in each group; all included in ITT analysis \\
\hline
\end{tabular}

Brandon 1987

$\begin{array}{ll}\text { Methods } & \text { Setting: cessation clinic, USA } \\ & \text { Recruitment: community volunteers }\end{array}$


Brandon 1987 (Continued)

$\begin{array}{ll} & 39 \text { smokers } \\ \text { Participants } & \text { Sex not specified, average age 31, average cigs/day } 27 \\ \text { Treatment: groups of } 3 \text { to } 7 \text { (probably) } & \text { Therapists: } 3 \text {, counterbalanced across treatments }\end{array}$

Interventions All-included cessation programme $6 \times 2$ hours over 2 weeks

1. Relapse prevention $4 \times 1.5$ hour sessions, 2, 4, 8, 12 weeks post-cessation: self-monitoring, advice, assignment of exposure and coping exercises

2. No maintenance, one assessment session at 12 weeks

\begin{tabular}{|c|c|c|}
\hline Outcomes & \multicolumn{2}{|c|}{$\begin{array}{l}\text { Abstinence at } 12 \text { months (assume point prevalence) (phone assessment, non-therapist). } \\
\text { Validation: CO only during treatment, phoning } 2 \text { collaterals - no results given }\end{array}$} \\
\hline Notes & \multicolumn{2}{|c|}{ A treatment arm that included rapid puffing not included } \\
\hline \multicolumn{3}{|l|}{ Risk of bias } \\
\hline Bias & Authors' judgement & Support for judgement \\
\hline $\begin{array}{l}\text { Random sequence genera- } \\
\text { tion (selection bias) }\end{array}$ & Unclear risk & $\begin{array}{l}\text { Randomly by treatment group before cessation programme, method not de- } \\
\text { scribed }\end{array}$ \\
\hline $\begin{array}{l}\text { Allocation concealment } \\
\text { (selection bias) }\end{array}$ & Unclear risk & No information given \\
\hline $\begin{array}{l}\text { Blinding of participants } \\
\text { and personnel (perfor- } \\
\text { mance bias) } \\
\text { All outcomes }\end{array}$ & Unclear risk & Not specified \\
\hline
\end{tabular}

\begin{tabular}{lll}
\hline $\begin{array}{l}\text { Blinding of outcome as- } \\
\text { sessment (detection bias) } \\
\text { All outcomes }\end{array}$ & Unclear risk & Biochemically validated abstinence but no results provided \\
\hline $\begin{array}{l}\text { Incomplete outcome data } \\
\text { (attrition bias) }\end{array}$ & Unclear risk & $\begin{array}{l}8 \text { randomly assigned participants did not achieve initial cessation and were } \\
\text { not included in analysis as their allocation was not given }\end{array}$ \\
\hline
\end{tabular}

Brandon 2000

\begin{tabular}{ll}
\hline Methods & $\begin{array}{l}\text { Setting: community, USA } \\
\text { Recruitment: advertisements for ex-smokers wanting to avoid relapse }\end{array}$ \\
\hline Participants & $\begin{array}{l}584 \text { ex-smokers (abstinent }>7 \text { days at baseline). } \\
\text { Average age } 49, \text { median abstinence } 6.5 \text { months, mean } 16 \text { months }\end{array}$ \\
\hline Interventions & $\begin{array}{l}2 \times 2 \text { factorial design testing mail and phone intervention } \\
\text { Mailings condition: } 8 \text { Stay Quit booklets mailed at } 1,2,3,5,7,9,12 \text { months }\end{array}$ \\
& $\begin{array}{l}\text { Hotline condition: information about Stay Quit hotline. Asked to call to register. Participants were } \\
\text { called if they did not register within } 2 \text { weeks and at } 3 \text { months if they had not called } \\
\text { Minimal contact condition received; first Stay Quit booklet }\end{array}$ \\
\hline Outcomes & $\begin{array}{l}\text { Abstinence at } 12 \text { months (no smoking in past } 7 \text { days) } \\
\text { All participants were abstinent at baseline, and relapse rates were low. }\end{array}$ \\
\hline
\end{tabular}


Brandon 2000 (Continued)

Validation: $\mathrm{CO}<10 \mathrm{ppm}$ for participants living within 75 miles of laboratory

$\begin{array}{ll}\text { Notes } & \text { No true control } \\ \text { Of } 804 \text { randomly assigned, results were based on } 584 \text { who met inclusion criteria and were sent materi- }\end{array}$

als (until 2009 update, denominator of 446 was used. Author provided additional data).

\section{Risk of bias}

\begin{tabular}{lll}
\hline Bias & Authors' judgement & Support for judgement \\
\hline $\begin{array}{l}\text { Random sequence genera- } \\
\text { tion (selection bias) }\end{array}$ & Unclear risk & Randomisation method not described \\
\hline $\begin{array}{l}\text { Allocation concealment } \\
\text { (selection bias) }\end{array}$ & Unclear risk & No details given \\
\hline $\begin{array}{l}\text { Blinding of participants } \\
\text { and personnel (perfor- } \\
\text { mance bias) }\end{array}$ & Unclear risk & Not specified \\
All outcomes & \\
\hline $\begin{array}{l}\text { Blinding of outcome as- } \\
\text { sessment (detection bias) } \\
\text { All outcomes }\end{array}$ & Low risk & "The Co results from the subsample suggest that participants' self-reported \\
\hline $\begin{array}{l}\text { Incomplete outcome data } \\
\text { (attrition bias) } \\
\text { All outcomes }\end{array}$ & Unclear risk & smoking status had satisfactory validity" \\
\hline
\end{tabular}

Brandon 2004

\begin{tabular}{|c|c|}
\hline Methods & $\begin{array}{l}\text { Setting: community, USA } \\
\text { Recruitment: advertisements for ex-smokers wanting to avoid relapse }\end{array}$ \\
\hline Participants & $\begin{array}{l}481 \text { ex-smokers (abstinent }>7 \text { days at baseline) } \\
66 \% \text { female, average age 52, average cigs/day } 25 . \text { Median } 75 \text { days of abstinence }\end{array}$ \\
\hline Interventions & $\begin{array}{l}2 \times 2 \text { factorial design testing effects of contact versus content } \\
\text { 1. Repeated mailings. High contact-high content. } 8 \text { "Forever Free" booklet mailings at enrolment and 1, } \\
\text { 2, 3, 5, 7, 8, } 12 \text { months } \\
\text { 2. Massed mailings. Low contact - high content. Same } 8 \text { booklets at enrolment } \\
\text { 3. Repeated letters. High contact - low content. Single "Forever Free" booklet, } 7 \text { supportive letters, } \\
\text { same schedule as } 1 \text {. Provided extended contact and social support without skills training } \\
\text { 4. Control. Low contact - low content. Single booklet, no further contact }\end{array}$ \\
\hline Outcomes & $\begin{array}{l}\text { Abstinence at } 24 \text { months (no smoking in past } 7 \text { days) } \\
\text { Validation: CO for } 21 \text { local quitters, no misreporting identified }\end{array}$ \\
\hline Notes & $\begin{array}{l}\text { New for } 2009 \text { update } \\
\text { No true control. Other } 3 \text { arms compared with single booklet condition in main analysis. Of } 895 \text { ran- } \\
\text { domly assigned, results based on } 431 \text { who met inclusion criteria and returned follow-up questionnaire. } \\
\text { Non-responders excluded rather than assumed to have relapsed }\end{array}$ \\
\hline
\end{tabular}


Brandon 2004 (Continued)

Risk of bias

\begin{tabular}{|c|c|c|}
\hline Bias & Authors' judgement & Support for judgement \\
\hline $\begin{array}{l}\text { Random sequence genera- } \\
\text { tion (selection bias) }\end{array}$ & Unclear risk & Randomisation method not described \\
\hline $\begin{array}{l}\text { Allocation concealment } \\
\text { (selection bias) }\end{array}$ & Unclear risk & No details given \\
\hline $\begin{array}{l}\text { Blinding of participants } \\
\text { and personnel (perfor- } \\
\text { mance bias) } \\
\text { All outcomes }\end{array}$ & Low risk & $\begin{array}{l}\text { Because of the nature of the intervention, blinding not possible, but no ad- } \\
\text { ditional phone or face contact between personnel and participants; lack of } \\
\text { blinding unlikely to affect performance }\end{array}$ \\
\hline $\begin{array}{l}\text { Blinding of outcome as- } \\
\text { sessment (detection bias) } \\
\text { All outcomes }\end{array}$ & Low risk & $\begin{array}{l}\text { Minimal contact, misreport unlikely to be differential and validation of sub- } \\
\text { group did not identify any misreporting }\end{array}$ \\
\hline $\begin{array}{l}\text { Incomplete outcome data } \\
\text { (attrition bias) } \\
\text { All outcomes }\end{array}$ & Low risk & $85 \%$ reached at 24 months, no differential dropout \\
\hline
\end{tabular}

Brandon 2012

Methods Setting: participants' own homes, USA

Recruitment: by phone via purchased telephone numbers from marketing companies

Participants 504 ex-smokers (abstinent $>7$ days at baseline), 245 intervention, 259 control

Pregnant women, average age 25, average cigs/day 15

Interventions

1. Relapse prevention: 9 'Forever Free' self-help booklets by post up to 8 months postpartum

2. Control: 2 leaflets, content not customised for pregnant women

\begin{tabular}{ll}
\hline Outcomes & 7-day point prevalence abstinence at $12 \mathrm{months}$ postpartum \\
& Validation: $\mathrm{CO}<8 \mathrm{ppm}$ and Cotinine $<10 \mathrm{ng} / \mathrm{mL}$ at 12 months only for participants within $100 \mathrm{miles}$ of \\
& lab, otherwise self-report
\end{tabular}

\begin{tabular}{ll}
\hline Notes & Funding: "This research was supported by National Cancer Institute (grant R01 CA94256)." \\
& Declaration of interests: not specified \\
\hline
\end{tabular}

\section{Risk of bias}

\begin{tabular}{lll}
\hline Bias & Authors' judgement & Support for judgement \\
\hline $\begin{array}{l}\text { Random sequence genera- } \\
\text { tion (selection bias) }\end{array}$ & Low risk & Computer algorithm for randomisation \\
\hline $\begin{array}{l}\text { Allocation concealment } \\
\text { (selection bias) }\end{array}$ & Unclear risk & Allocation concealment not described \\
\hline
\end{tabular}


Brandon 2012 (Continued)
Blinding of participants
Unclear risk
Blinding not mentioned and personnel (performance bias)

All outcomes

\begin{tabular}{lll}
\hline $\begin{array}{l}\text { Blinding of outcome as- } \\
\text { sessment (detection bias) } \\
\text { All outcomes }\end{array}$ & Unclear risk & $\begin{array}{l}\text { Biochemically validation of abstinence only in participants within } 100 \text { miles of } \\
\text { researchers }\end{array}$ \\
\hline $\begin{array}{l}\text { Incomplete outcome data } \\
\text { (attrition bias) }\end{array}$ & Low risk & Dropout rates similar between study arms \\
All outcomes & \\
\hline
\end{tabular}

\section{Brandstein 2012}

\begin{tabular}{ll}
\hline Methods & Setting: hospital, USA \\
& Recruitment: hospitalised patients \\
\hline Participants & 126 ex-smokers (quit during hospitalisation), 64 intervention and 62 control \\
& $65 \%$ male, average age: 47, average cigs/day: 10 to 20 \\
\hline Interventions & $\begin{array}{l}\text { Relapse prevention: as control plus 8-week supply of nicotine patches, telephone counselling up to } 2 \\
\text { months post-discharge and mailed self-help materials }\end{array}$ \\
& Control: brief 'Ask, Advise and Refer' beside intervention by a respiratory therapist \\
\hline Outcomes & $\begin{array}{l}180 \text { days prolonged abstinence at } 6 \text { months } \\
\text { Validation: Self-report plus saliva sample bogus pipeline test }\end{array}$ \\
\hline Notes & Funding: "This study was funded by a \$50,000 grant from the Scripps Clinical Research Development \\
& Declaration of interest: not reported \\
\hline
\end{tabular}

\section{Risk of bias}

\begin{tabular}{|c|c|c|}
\hline Bias & Authors' judgement & Support for judgement \\
\hline $\begin{array}{l}\text { Random sequence genera- } \\
\text { tion (selection bias) }\end{array}$ & Low risk & $\begin{array}{l}\text { Quote: "The PI used computer generated randomization lists so that random- } \\
\text { ization was stratified by the RT and subjects were allocated to treatment con- } \\
\text { dition using blocks of four." }\end{array}$ \\
\hline $\begin{array}{l}\text { Allocation concealment } \\
\text { (selection bias) }\end{array}$ & Unclear risk & Unclear allocation concealment \\
\hline $\begin{array}{l}\text { Blinding of participants } \\
\text { and personnel (perfor- } \\
\text { mance bias) } \\
\text { All outcomes }\end{array}$ & Unclear risk & Blinding not reported \\
\hline $\begin{array}{l}\text { Blinding of outcome as- } \\
\text { sessment (detection bias) } \\
\text { All outcomes }\end{array}$ & Unclear risk & $\begin{array}{l}\text { Abstinence self-reported with saliva sampling for bogus pipeline testing in mi- } \\
\text { nority }\end{array}$ \\
\hline
\end{tabular}


Brandstein 2012 (Continued)

Incomplete outcome data Low risk (attrition bias)

All outcomes
Quote: "The contact rate for the six-month evaluation was $57.9 \%$. There was no significant difference in contact between the groups; $62.5 \%$ and $56.4 \%$ were evaluated in the enhanced and control conditions, respectively $(\mathrm{p}=$ 0.48)."

Buchkremer 19911

\begin{tabular}{ll} 
Methods & $\begin{array}{l}\text { Setting: cessation clinic, Germany } \\
\text { Recruitment: community volunteers }\end{array}$ \\
\hline Participants & 256 smokers, no demographic details \\
\hline Interventions & $\begin{array}{l}5 \text { conditions, partly factorial. All received nicotine patch, dose individualised for conditions } 1 \text { to 4, plus } \\
9 \text { weekly sessions, including reduction, self-monitoring, contract management, risk avoidance. TQD af- } \\
\text { ter } 6 \text { weeks }\end{array}$ \\
1. Additional training in relapse-coping strategies (during cessation phase) & $\begin{array}{l}\text { 2. Additional } 3 \text { booster sessions, } 6 \text { months after end of main therapy } \\
\text { 3. Relapse-coping and boosters } \\
\text { 4. Control } \\
\text { 5. Control (fixed-dose nicotine patch) }\end{array}$ \\
\hline
\end{tabular}

\begin{tabular}{ll} 
Outcomes & $\begin{array}{l}\text { Abstinence } 12 \text { months post-EOT (point prevalence). Rates estimated from graphs } \\
\text { Validation: random urine nicotine, 'almost } 100 \% \text { conformity', no correction }\end{array}$ \\
\hline Notes & $\begin{array}{l}3 \text { versus } 4 \text { in contact matched comparison, } 1 \text { plus } 2 \text { versus } 4 \text { in extended contact comparison } \\
\text { Inclusion of control group } 5 \text { (fixed dose) would marginally increase intervention benefit }\end{array}$ \\
\hline
\end{tabular}

\section{Risk of bias}

\begin{tabular}{|c|c|c|}
\hline Bias & Authors' judgement & Support for judgement \\
\hline $\begin{array}{l}\text { Random sequence genera- } \\
\text { tion (selection bias) }\end{array}$ & Unclear risk & $\begin{array}{l}\text { "Randomly assigned to experimental groups after previously being matched } \\
\text { for age, sex and cigarette consumption" }\end{array}$ \\
\hline $\begin{array}{l}\text { Allocation concealment } \\
\text { (selection bias) }\end{array}$ & Unclear risk & No details given \\
\hline $\begin{array}{l}\text { Blinding of participants } \\
\text { and personnel (perfor- } \\
\text { mance bias) } \\
\text { All outcomes }\end{array}$ & Unclear risk & No information provided \\
\hline $\begin{array}{l}\text { Blinding of outcome as- } \\
\text { sessment (detection bias) } \\
\text { All outcomes }\end{array}$ & Low risk & $\begin{array}{l}\text { No blinding reported but biochemical confirmation taken at random, with 'al- } \\
\text { most } 100 \% \text { conformity' }\end{array}$ \\
\hline $\begin{array}{l}\text { Incomplete outcome data } \\
\text { (attrition bias) } \\
\text { All outcomes }\end{array}$ & Unclear risk & $\begin{array}{l}15 / 256(5.9 \%) \text { dropouts excluded, assignment not given, so not included in } \\
\text { analysis }\end{array}$ \\
\hline
\end{tabular}


Buchkremer 19912

\begin{tabular}{ll}
\hline Methods & $\begin{array}{l}\text { Setting: cessation clinic, Germany } \\
\text { Recruitment: community volunteers }\end{array}$ \\
\hline Participants & 185 smokers, no demographic details \\
\hline Interventions & $\begin{array}{l}4 \text { conditions, partly factorial. All received nicotine patch (dose individualised for conditions } 1 \text { to 3) plus } \\
9 \text { weekly sessions, including reduction, self-monitoring, contract management, risk avoidance. TQD af- } \\
\text { ter } 6 \text { weeks }\end{array}$ \\
1. Relapse coping training using role play, TQD at 6 weeks \\
2. Modified relapse coping. Rapid abstinence, TQD session 4, covert sensitisation, thought-stopping \\
3. Control, individualised patch dose \\
4. Control, fixed patch dose
\end{tabular}

\begin{tabular}{ll} 
Outcomes & $\begin{array}{l}\text { Abstinence } 12 \text { months post-EOT (point prevalence). Rates estimated from graphs } \\
\text { Validation: random urine, 'almost } 100 \% \text { conformity', no correction }\end{array}$ \\
\hline Notes & $\begin{array}{l}1 \text { plus } 2 \text { versus } 3 \text { in contact matched comparison. Inclusion of control group } 4 \text { (fixed dose) would mar- } \\
\text { ginally increase intervention benefit }\end{array}$
\end{tabular}

\section{Risk of bias}

\begin{tabular}{lll}
\hline Bias & Authors' judgement & Support for judgement \\
\hline $\begin{array}{l}\text { Random sequence genera- } \\
\text { tion (selection bias) }\end{array}$ & Unclear risk & $\begin{array}{l}\text { 'Randomly assigned to experimental groups after previously being matched } \\
\text { for age, sex and cigarette consumption' }\end{array}$ \\
\hline $\begin{array}{l}\text { Allocation concealment } \\
\text { (selection bias) }\end{array}$ & Unclear risk & No details given \\
\hline $\begin{array}{l}\text { Blinding of participants } \\
\text { and personnel (perfor- } \\
\text { mance bias) } \\
\text { All outcomes }\end{array}$ & Unclear risk & No information provided \\
\hline
\end{tabular}

\begin{tabular}{lll}
\hline $\begin{array}{l}\text { Blinding of outcome as- } \\
\text { sessment (detection bias) } \\
\begin{array}{l}\text { All outcomes } \\
\text { Incomplete outcome data }\end{array}\end{array}$ & Low risk & $\begin{array}{l}\text { No blinding reported but biochemical confirmation taken at random, with 'al- } \\
\text { most } 100 \% \text { conformity' }\end{array}$ \\
\hline $\begin{array}{l}\text { (attrition bias) } \\
\text { All outcomes }\end{array}$ & $\begin{array}{l}23 / 185(12.4 \%) \text { dropouts excluded, assignment not given, so not included in } \\
\text { analysis }\end{array}$ \\
\hline
\end{tabular}

\begin{tabular}{ll} 
Campos 2018 & \\
\hline Methods & Setting: Inpatient department of university hospital, Brazil \\
& Recriutment: Enrolled within first 48 hours of hospital admission \\
\hline Participants & 90 inpatients \\
& $61 \%$ male, average age 51 , average cigs/day 20.7 \\
\hline
\end{tabular}


Campos 2018 (Continued) Interventions
Intervention: Counselled in a session that lasted approximately $40 \mathrm{~min}$, comprising a 10-min oral intervention and a 30-min educational video presentation

Control: Counselled on the dangers of smoking and the benefits of quitting in an ordinary session lasting $10 \mathrm{~min}$

6 months after discharge

Validation: Exhaled carbon monoxide

Funding: publisher website claimed no funding

Declaration of interests: none reported

\section{Risk of bias}

\begin{tabular}{|c|c|c|}
\hline Bias & Authors' judgement & Support for judgement \\
\hline $\begin{array}{l}\text { Random sequence genera- } \\
\text { tion (selection bias) }\end{array}$ & Unclear risk & Method of randomisation not specified \\
\hline $\begin{array}{l}\text { Allocation concealment } \\
\text { (selection bias) }\end{array}$ & Unclear risk & Concealment not reported \\
\hline $\begin{array}{l}\text { Blinding of participants } \\
\text { and personnel (perfor- } \\
\text { mance bias) } \\
\text { All outcomes }\end{array}$ & Low risk & $\begin{array}{l}\text { Blinding not performed, but face-to-face contact was the same between the } \\
\text { two groups, so performance bias unlikely. }\end{array}$ \\
\hline $\begin{array}{l}\text { Blinding of outcome as- } \\
\text { sessment (detection bias) } \\
\text { All outcomes }\end{array}$ & Low risk & $\begin{array}{l}\text { Smoking status was assessed and self-reported abstinence was biochemical- } \\
\text { ly validated by measuring exhaled carbon monoxide (eCO) with a portable } \\
\text { breath analyser. }\end{array}$ \\
\hline $\begin{array}{l}\text { Incomplete outcome data } \\
\text { (attrition bias) } \\
\text { All outcomes }\end{array}$ & Low risk & $\begin{array}{l}\text { Of the } 90 \text { participants evaluated, } 9 \text { were excluded from the 6-month assess- } \\
\text { ment. }\end{array}$ \\
\hline
\end{tabular}

\section{Cheung 2015}

\begin{tabular}{ll}
\hline Methods & Setting: mobile apps, Hong Kong \\
& Recruitment: patients of smoking cessation centre \\
\hline Participants & 136 ex-smokers (7-day abstinence), 42 Whatsapp, 40 Facebook and 54 Control \\
& $76.5 \%$ male, average age 40, average cigs/day 15 \\
\hline Interventions & Whatsapp: Control + Whatsapp online group with 3 reminders per week from moderator and booklet \\
& Facebook: Control + Facebook online group with 3 reminders per week from moderator and booklet \\
Control: 8-week counselling, telephone follow-ups, physician assessment and free NRT
\end{tabular}

\begin{tabular}{ll}
\hline Outcomes & 7-day point prevalence at 6 months \\
& Validation: $\mathrm{CO}>4 \mathrm{ppm}$ and cotinine $<10 \mathrm{ng} / \mathrm{mL}$ at 6 months
\end{tabular}


Cheung 2015 (Continued)

Notes
Participants given $\mathrm{HK} \$ 100$ if validated as abstinent. Only participants who reported abstinence were notified of incentive.

Funding: "the Tung Wah Group of Hospitals Integrated Centre on Smoking Cessation (ICSC) and Tobacco Control Office of Hong Kong Department of Health"

Declaration of interests: "The study was funded by Tung Wah Group of Hospitals Integrated Centre on Smoking Cessation, which was funded by Tobacco Control Office of Department of Health. Prof Taihing Lam is the principal investigator of the FAMILY project, which was funded by the Hong Kong Jockey Club Charities Trust. All other authors do not have connection with the tobacco, alcohol, pharmaceutical, or gaming industries, and nobody was substantially funded by one of these organizations"

\section{Risk of bias}

\begin{tabular}{lll}
\hline Bias & Authors' judgement & Support for judgement \\
\hline $\begin{array}{l}\text { Random sequence genera- } \\
\text { tion (selection bias) }\end{array}$ & Low risk & Computerised cluster-randomisation \\
\hline $\begin{array}{l}\text { Allocation concealment } \\
\text { (selection bias) }\end{array}$ & High risk & Counsellors but not participants were aware of group allocation sequence \\
\hline $\begin{array}{l}\text { Blinding of participants } \\
\begin{array}{l}\text { and personnel (perfor- } \\
\text { mance bias) }\end{array}\end{array}$ & Low risk & Quote: "All participants received a specific relapse prevention intervention, \\
All outcomes & & but they did not know what the other interventions were."
\end{tabular}

\begin{tabular}{lll}
\hline $\begin{array}{l}\text { Blinding of outcome as- } \\
\text { sessment (detection bias) } \\
\text { All outcomes }\end{array}$ & Low risk & $\begin{array}{l}\text { Quote: "All assessors of outcomes were blinded to the RCT group of each par- } \\
\text { ticipant." Results biochemically verified. }\end{array}$ \\
\hline $\begin{array}{l}\text { Incomplete outcome data } \\
\begin{array}{l}\text { (attrition bias) } \\
\text { All outcomes }\end{array}\end{array}$ & Low risk & Low rates of attrition \\
\hline Other bias & Unclear risk & Not clear if adjusted for cluster randomisation \\
\hline
\end{tabular}

\section{Coleman-Cowger 2018}

\begin{tabular}{ll}
\hline Methods & Setting: Academic obstetrics clinic, USA \\
& Recruitment: While attending first prenatal visit \\
\hline Participants & 128 pregnant women, low-income \\
& $100 \%$ women, average age 26, average cigs/day 8.6 \\
\hline Interventions & $\begin{array}{l}\text { Intervenion: Standard care + Phone-based Postpartum Continuing Care - } 10 \text { phone calls with health } \\
\text { coach using motivated interviewing techniques, recovery management checkups and } 5 \text { A's (questions) } \\
\text { Control: standard care only }\end{array}$ \\
\hline Outcomes & 7-day PP abstinence \\
\hline Validation: Urine cotinine
\end{tabular}


Coleman-Cowger 2018 (Continued)

Declaration of interests: not reported

\section{Risk of bias}

\begin{tabular}{lll}
\hline Bias & Authors' judgement & Support for judgement \\
\hline $\begin{array}{l}\text { Random sequence genera- } \\
\text { tion (selection bias) }\end{array}$ & Low risk & Computer-based urn randomisation \\
\hline $\begin{array}{l}\text { Allocation concealment } \\
\text { (selection bias) }\end{array}$ & Unclear risk & $\begin{array}{l}\text { Project Coordinator informed Chestnut Global Partners (CGP) staff (via email) } \\
\text { and participants (via mailed letter with an enclosed "Healthy Mom, Healthy } \\
\text { Baby" booklet and pedometer) within one week of assignment to the experi- } \\
\text { mental group. }\end{array}$
\end{tabular}

Blinding of participants High risk Participants were not blinded, and contact levels differed between study arms. and personnel (performance bias)

All outcomes

Blinding of outcome as-
sessment (detection bias) $\quad$ Low risk $\quad$ Abstinence biochemically validated
sessment (detection bias)

All outcomes

Incomplete outcome data Low risk
(attrition bias) Sixteen participants $(25 \%)$ withdrew from the Intervention only $(n=13)$ or All outcomes from the entire study $(n=3)$.

Conway 2004

\begin{tabular}{ll}
\hline Methods & $\begin{array}{l}\text { Setting: Naval training, USA } \\
\text { Recruitment: smokers who had enforced abstinence during naval training, unselected, not volunteers }\end{array}$ \\
\hline Participants & $\begin{array}{l}\text { 1682 female navy recruits with a history of smoking (661 reached at follow-up). All should have been } \\
\text { abstinent for } 2 \text { months during training, } \\
\text { average age } 19, \text { no details of cigs/day }\end{array}$
\end{tabular}

Interventions

1. 6 mail contacts over 12 months, at 1, 2, 4, 5, 7, 10 months ( 2 after follow-up), 1-page flyers, cognitive-behavioural relapse prevention; stress management, weight, fitness, tailored for naval women

2. Access to toll-free telephone helpline for support and counselling on relapse prevention and quitting if relapse occurred, cognitive-behavioural approach. Once participant called, sessions scheduled in line with risk of relapse

3. No intervention control

\begin{tabular}{ll}
\hline Outcomes & $\begin{array}{l}\text { Abstinence at } 12 \text { months (30-day) (Edwards } 1999 \text { reported 6-month outcomes) } \\
\text { Validation: none }\end{array}$ \\
\hline Notes & $\begin{array}{l}\text { Results not displayed graphically because denominators not explicit. No evidence of intervention ef- } \\
\text { fect. Impact of clustering was negligible }\end{array}$ \\
\hline
\end{tabular}

\section{Risk of bias}

Bias Authors' judgement Support for judgement


Conway 2004 (Continued)

Random sequence genera- Unclear risk Cluster randomisation by division (80 people) tion (selection bias)

\begin{tabular}{lll}
\hline $\begin{array}{l}\text { Allocation concealment } \\
\text { (selection bias) }\end{array}$ & Unclear risk & No details given \\
\hline $\begin{array}{l}\text { Blinding of participants } \\
\text { and personnel (perfor- } \\
\text { mance bias) }\end{array}$ & Unclear risk & No information provided \\
All outcomes & \\
\hline
\end{tabular}

\begin{tabular}{|c|c|c|}
\hline $\begin{array}{l}\text { Blinding of outcome as- } \\
\text { sessment (detection bias) }\end{array}$ & Low risk & $\begin{array}{l}\text { Self-reported smoking status, interventions of varying intensities, but no face- } \\
\text { to-face contact, so judged to be unlikely }\end{array}$ \\
\hline
\end{tabular}

All outcomes

\begin{tabular}{|c|c|c|}
\hline $\begin{array}{l}\text { Incomplete outcome data } \\
\text { (attrition bias) }\end{array}$ & Unclear risk & $\begin{array}{l}\text { High loss to follow-up ( } 52 \% \text { at } 12 \text { months); participants lost to follow-up not } \\
\text { broken down by group; unclear whether included in final denominators }\end{array}$ \\
\hline
\end{tabular}

(attrition bias)

broken down by group; unclear whether included in final denominators

All outcomes

Covey 2007

$\begin{array}{ll}\text { Methods } & \text { Setting: cessation clinic, USA } \\ & \text { Recruitment: community volunteers quit after } 8 \text { weeks bupropion \& nicotine patch }\end{array}$

Participants
$\begin{aligned} & 45 \% \text { abstainers (excludes } 5 \text { withdrawing consent before starting medication) } \\ & \text { Therapists: counsellors, } 1 \text {-month training }\end{aligned}$

Interventions

All participants received 8 weeks open-label bupropion and nicotine patch ( $21 \mathrm{mg}$ with weaning) for 7 weeks from TQD. Transition procedures preserved blinding for the relapse prevention phase but allowed weaning from bupropion. Individual counselling, including CBT techniques, 15 minutes $\times 6$ during open-label, $\times 4$ during relapse prevention, $\times 2$ during follow-up

1. Bupropion (300 mg) and nicotine gum ( $2 \mathrm{mg}$, use as needed to manage craving) for 16 weeks

2. Bupropion and placebo gum

3. Nicotine gum and placebo pill (150 mg bupropion for first week)

4. Double placebo (150 $\mathrm{mg}$ bupropion for first week)

\begin{tabular}{ll} 
Outcomes & $\begin{array}{l}\text { Abstinence (no relapse to } 7 \text { days of smoking) for } 12 \text { months (10 months after randomisation, } 6 \text { months } \\
\text { after EOT) (primary outcome for study was time to relapse) } \\
\text { Validation: CO } \leq 8 \text { ppm at each visit }\end{array}$ \\
\hline Notes & $\begin{array}{l}\text { New for } 2009 \text { update } \\
\text { Contributed to NRT, bupropion, and combination therapy analyses } \\
\text { Quit rate after open-label treatment was } 52 \% \text {, so the final quit rate of } 30 \% \text { for combination therapy is } \\
\text { equivalent to } 16 \% \text { of people starting treatment }\end{array}$
\end{tabular}

\section{Risk of bias}

Bias Authors' judgement Support for judgement


Covey 2007 (Continued)

Random sequence genera- Low risk "A statistician who did not participate in the clinical phases of the study protion (selection bias) vided computer-generated randomization lists that were not accessible to the clinical staff", stratified by gender and depression history

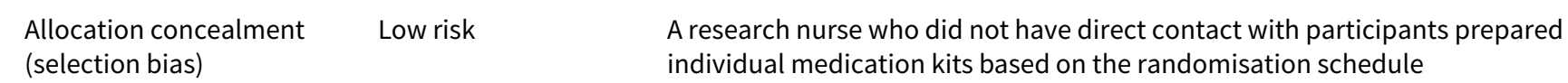

Blinding of participants Low risk "Participants and clinical researchers with direct participant contact were
and personnel (perfor- blinded to the randomization". Identical placebos used

mance bias)

All outcomes

\begin{tabular}{lll}
\hline $\begin{array}{l}\text { Blinding of outcome as- } \\
\text { sessment (detection bias) } \\
\text { All outcomes }\end{array}$ & Low risk & Biochemical validation used at each visit \\
\hline $\begin{array}{l}\text { Incomplete outcome data } \\
\text { (attrition bias) }\end{array}$ & Low risk & $\begin{array}{l}5 \text { randomly assigned participants withdrew before double-blind phase. } \\
\text { Greater loss to follow-up in double placebo, losses included in ITT analysis }\end{array}$ \\
\hline
\end{tabular}

\section{Croghan 2007}

\begin{tabular}{ll}
\hline Methods & $\begin{array}{l}\text { Setting: clinic, USA } \\
\text { Recruitment: community volunteers for pharmacotherapy cessation and relapse prevention trial }\end{array}$ \\
\hline Participants & $\begin{array}{l}405 \text { abstainers after } 3 \text { months pharmacotherapy, } 74 \text { from inhaler, } 141 \text { bupropion, } 190 \text { combination } \\
\text { Participant characteristics not presented at start of relapse prevention phase }\end{array}$ \\
\hline Interventions & $\begin{array}{l}\text { In cessation phase, participants had been randomly assigned to bupropion (300 mg), nicotine inhaler } \\
\text { (up to } 16 \text { cartridges/day) or combination. Physician advice at entry, brief (<10 min) counselling at } \\
\text { monthly study visits (total } 12 \text { to 18, including relapse prevention phase) and self-help. Abstainers (7- } \\
\text { day point prevalence after } 3 \text { months therapy) eligible for relapse prevention phase } \\
\text { relapse prevention intervention randomly assigned single-therapy abstainers to continue cessation } \\
\text { therapy or placebo for } 9 \text { months } \\
\text { Combined therapy abstainers randomly assigned to 4 groups: combination, placebo and single thera- } \\
\text { py, or double placebo }\end{array}$ \\
\hline Outcomes & $\begin{array}{l}\text { Abstinence at } 15 \text { months (from TQD, 12 months from relapse prevention start, 3 months from EOT) (PP) } \\
\text { Validation: CO } \leq 8 \text { ppm }\end{array}$ \\
\hline Notes & $\begin{array}{l}\text { New for } 2009 \text { update } \\
\text { Arms contributed to NRT, bupropion, and combination therapy analyses, ignoring differences in cessa- } \\
\text { tion induction therapy } \\
\text { Cessation rates at end of induction phase were 14\% for inhaler, 26\% for bupropion, and 34\% for com- } \\
\text { bination }\end{array}$ \\
\hline
\end{tabular}

\section{Risk of bias}

\begin{tabular}{lll}
\hline Bias & Authors' judgement & Support for judgement \\
\hline $\begin{array}{l}\text { Random sequence genera- } \\
\text { tion (selection bias) }\end{array}$ & Low risk & $\begin{array}{l}\text { Randomisation using a dynamic allocation procedure and balancing stratifica- } \\
\text { tion factors }\end{array}$ \\
\hline $\begin{array}{l}\text { Allocation concealment } \\
\text { (selection bias) }\end{array}$ & Low risk & Randomisation procedure made prior knowledge of allocation unlikely \\
\hline
\end{tabular}


Croghan 2007 (Continued)

Blinding of participants Unclear risk Placebo used, but insufficient information provided re: blinding to permit and personnel (performance bias)

All outcomes

\begin{tabular}{lll}
\hline $\begin{array}{l}\text { Blinding of outcome as- } \\
\text { sessment (detection bias) } \\
\text { All outcomes }\end{array}$ & Low risk & Biochemical validation used \\
\hline $\begin{array}{l}\text { Incomplete outcome data } \\
\text { (attrition bias) }\end{array}$ & Low risk & $\begin{array}{l}\text { Losses to follow-up post-medication were high and were not enumerated by } \\
\text { All outcomes }\end{array}$ \\
\hline
\end{tabular}

\section{Cummins 2016}

\begin{tabular}{|c|c|c|}
\hline \multirow[t]{3}{*}{ Methods } & \multicolumn{2}{|l|}{ Setting: hospitals, USA } \\
\hline & \multicolumn{2}{|c|}{ Recruitment: hospitalised smokers approached by Respiratory Therapists } \\
\hline & \multicolumn{2}{|c|}{ Design: $2 \times 2$ (nicotine patches $\times$ counselling) factorial design } \\
\hline Participants & \multicolumn{2}{|c|}{1270 smokers, 320 no patches, 317 patches, 317 no counselling, 316 counselling } \\
\hline & \multicolumn{2}{|c|}{$56.7 \%$ male, average age 50, average cigs/day 15} \\
\hline \multirow[t]{5}{*}{ Interventions } & \multicolumn{2}{|l|}{$2 \times 2$ factorial design } \\
\hline & \multicolumn{2}{|c|}{$\begin{array}{l}\text { Intervention } 1 \text { : control plus NRT patches matched to cigs/day: } 6 \text { to } 10 \text { cigs/day = } 6 \text { weeks of } 14 \mathrm{mg} \\
\text { patches and } 2 \text { weeks of } 7 \mathrm{mg} \text { patches. } 11 /+ \text { cigs/day = } 4 \text { weeks of } 21 \mathrm{mg} \text { patches and } 2 \text { weeks of } 14 \mathrm{mg} \\
\text { patches and } 2 \text { weeks of } 7 \mathrm{mg} \text { patches }\end{array}$} \\
\hline & \multicolumn{2}{|c|}{$\begin{array}{l}\text { Intervention 2: control plus telephone counselling: initial call: } 30 \text { to } 40 \text { minutes, with up to } 8 \text { follow-up } \\
\text { calls of } 10-15 \text { minutes }\end{array}$} \\
\hline & \multicolumn{2}{|c|}{ Intervention 3: control plus telephone counselling and patches } \\
\hline & \multicolumn{2}{|c|}{ Control: standard care: brief beside intervention $<10$ minutes } \\
\hline Outcomes & \multicolumn{2}{|c|}{ 30-day point prevalence at 6 months } \\
\hline & \multicolumn{2}{|c|}{ Validation: Cotinine $<10 \mathrm{ng} / \mathrm{mL}$ at 6 months } \\
\hline \multirow[t]{3}{*}{ Notes } & \multicolumn{2}{|c|}{ No attempt to constrain participants from using other quit-smoking services } \\
\hline & \multicolumn{2}{|c|}{ Funding: "This research was supported by a grant from the National Cancer Institute (CA159533)" } \\
\hline & \multicolumn{2}{|c|}{ Declaration of interests: "No financial disclosures were reported by the authors of this paper." } \\
\hline \multicolumn{3}{|l|}{ Risk of bias } \\
\hline Bias & Authors' judgement & Support for judgement \\
\hline $\begin{array}{l}\text { Random sequence genera- } \\
\text { tion (selection bias) }\end{array}$ & Low risk & Computer randomisation stratified by recruitment site and cigarettes per day \\
\hline $\begin{array}{l}\text { Allocation concealment } \\
\text { (selection bias) }\end{array}$ & Unclear risk & Concealment not described \\
\hline
\end{tabular}


Cummins 2016 (Continued)
Blinding of participants
Unclear risk
Blinding not described and personnel (perfor- mance bias)
All outcomes

\begin{tabular}{lll}
\hline $\begin{array}{l}\text { Blinding of outcome as- } \\
\text { sessment (detection bias) }\end{array}$ & Low risk & \\
All outcomes & \\
\hline $\begin{array}{l}\text { Incomplete outcome data } \\
\text { (attrition bias) }\end{array}$ & Low risk & Low rates of attrition \\
All outcomes & \\
\hline
\end{tabular}

\section{Curry 1988}

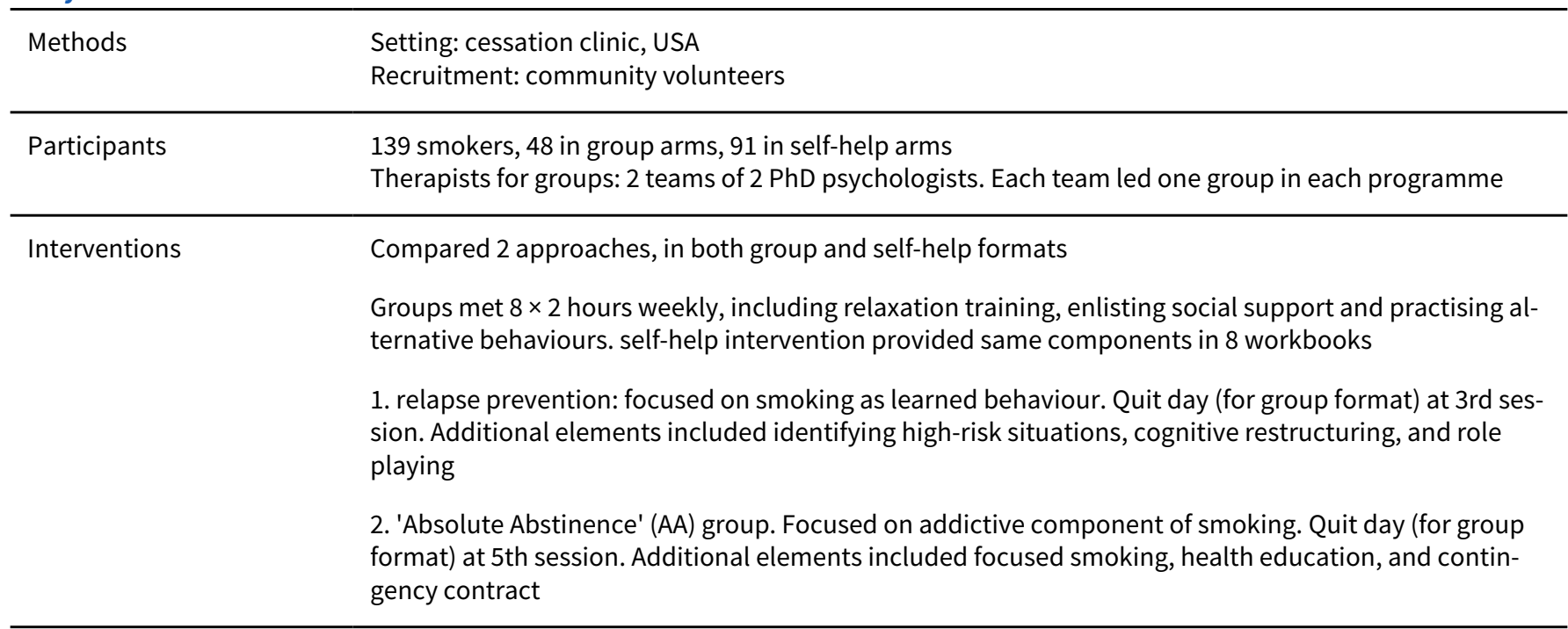

$\begin{array}{ll}\text { Outcomes } & \text { Abstinence from month } 9 \text { to month } 12 \text { of follow-up } \\ \text { Validation: saliva thiocyanate and two collateral verifiers }\end{array}$

Notes

Group and self-help arms used in different comparisons within the matched contact time section

\section{Risk of bias}

\begin{tabular}{lll}
\hline Bias & Authors' judgement & Support for judgement \\
\hline $\begin{array}{l}\text { Random sequence genera- } \\
\text { tion (selection bias) }\end{array}$ & Low risk & $\begin{array}{l}\text { Part by coin toss and part random number table. Friends co-randomly as- } \\
\text { signed to same programme but not necessarily same format. More assigned to } \\
\text { self-help than group by design }\end{array}$ \\
\hline $\begin{array}{l}\text { Allocation concealment } \\
\text { (selection bias) }\end{array}$ & High risk & $\begin{array}{l}\text { No details given, but randomisation procedure made it likely that it was not } \\
\text { concealed }\end{array}$ \\
\hline $\begin{array}{l}\text { Blinding of participants } \\
\begin{array}{l}\text { and personnel (perfor- } \\
\text { mance bias) }\end{array}\end{array}$ & Unclear risk & No information reported \\
$\begin{array}{l}\text { All outcomes } \\
\begin{array}{l}\text { Blinding of outcome as- } \\
\text { sessment (detection bias) }\end{array}\end{array}$ & Low risk & Abstinence validated \\
\hline
\end{tabular}


Curry 1988 (Continued)

All outcomes

Incomplete outcome data Low risk $\quad$ Only $69 \%$ began treatment. Losses to follow-up included an ITT analysis
(attrition bias)
(attrition bias)

All outcomes

Davis 1986

$\begin{array}{ll}\text { Methods } & \text { Setting: cessation clinic, USA } \\ & \text { Recruitment: community volunteers } \\ & \text { Group size: } 3 \text { to } 8\end{array}$

Participants
Therapists: 9 advanced clinical psychology graduate students with no previous experience. Each con-
ducted one group

Interventions All conditions received $6 \times 1 \frac{1}{2}$ to 2 hour weekly meetings based on Pomerleau and Pomerleau broad-
spectrum cessation package. TQD week 5
1. 'Experimental' condition added active cognitive behavioral skills training focusing on 11 problem sit-
uations
2. 'Enhanced control' added discussion of same problems
3. 'Control' using Pomerleau and Pomerleau alone

\begin{tabular}{ll}
\hline Outcomes & $\begin{array}{l}\text { Abstinence at } 12 \text { months (point prevalence) } \\
\text { Validation: } \mathrm{CO}\end{array}$ \\
\hline Notes & $\begin{array}{l}1 \text { and } 2 \text { treated as relapse prevention } \\
\text { Condition } 2 \text { not displayed. } 3 / 14 \text { quit }\end{array}$ \\
\hline
\end{tabular}

\section{Risk of bias}

\begin{tabular}{|c|c|c|}
\hline Bias & Authors' judgement & Support for judgement \\
\hline $\begin{array}{l}\text { Random sequence genera- } \\
\text { tion (selection bias) }\end{array}$ & Unclear risk & Randomisation method not described \\
\hline $\begin{array}{l}\text { Allocation concealment } \\
\text { (selection bias) }\end{array}$ & Unclear risk & No details given \\
\hline $\begin{array}{l}\text { Blinding of participants } \\
\text { and personnel (perfor- } \\
\text { mance bias) } \\
\text { All outcomes }\end{array}$ & Low risk & $\begin{array}{l}\text { Blinding not possible because of nature of the intervention, but all partici- } \\
\text { pants received same amount of contact, and no therapists had previous expe- } \\
\text { rience with stop-smoking groups, hence performance bias unlikely }\end{array}$ \\
\hline $\begin{array}{l}\text { Blinding of outcome as- } \\
\text { sessment (detection bias) } \\
\text { All outcomes }\end{array}$ & Low risk & Biochemical validation used \\
\hline $\begin{array}{l}\text { Incomplete outcome data } \\
\text { (attrition bias) } \\
\text { All outcomes }\end{array}$ & Unclear risk & $\begin{array}{l}5 \text { pretreatment and } 6 \text { dropouts during treatment excluded, assignment not } \\
\text { specified }\end{array}$ \\
\hline
\end{tabular}


Durmaz 2019

\begin{tabular}{|c|c|}
\hline Methods & $\begin{array}{l}\text { Setting: Smoking cessation outpatient clinic, Turkey } \\
\text { Recruitment: Whilst participants were applying to the clinic }\end{array}$ \\
\hline Participants & $\begin{array}{l}132 \text { smokers wanting help to quit } \\
61 \% \text { male, } 39.4 \text { average age }\end{array}$ \\
\hline Interventions & $\begin{array}{l}\text { Common components: } 45 \text {-min counselling, support booklet on quitting, relapse prevention compo- } \\
\text { nent } \\
\text { Intervention: + } 60 \text { WhatsApp messages about having a plan of action and preventing relapse were de- } \\
\text { veloped through expert panels for } 3 \text { months. } \\
\text { Control: common component only }\end{array}$ \\
\hline Outcomes & Self-report continuous prevalence at 6 months \\
\hline Notes & $\begin{array}{l}\text { Funding: none } \\
\text { Declaration of interests: no competing interests }\end{array}$ \\
\hline
\end{tabular}

\section{Risk of bias}

\begin{tabular}{|c|c|c|}
\hline Bias & Authors' judgement & Support for judgement \\
\hline $\begin{array}{l}\text { Random sequence genera- } \\
\text { tion (selection bias) }\end{array}$ & Low risk & Stratified randomization achieved using a computer spreadsheet \\
\hline $\begin{array}{l}\text { Allocation concealment } \\
\text { (selection bias) }\end{array}$ & Low risk & $\begin{array}{l}\text { The researcher enrolling participants did not know in advance which treat- } \\
\text { ment the next person would get, which guaranteed allocation concealment. }\end{array}$ \\
\hline $\begin{array}{l}\text { Blinding of participants } \\
\text { and personnel (perfor- } \\
\text { mance bias) } \\
\text { All outcomes }\end{array}$ & Low risk & $\begin{array}{l}\text { Participants and the researcher who sent the messages were not blinded but } \\
\text { face-to-face contact amounts did not vary between study groups. }\end{array}$ \\
\hline $\begin{array}{l}\text { Blinding of outcome as- } \\
\text { sessment (detection bias) } \\
\text { All outcomes }\end{array}$ & Low risk & $\begin{array}{l}\text { Abstinence was not biochemically validated, but face-to-face contact amounts } \\
\text { did not vary between study groups and the physicians were blind throughout } \\
\text { the follow ups as well. }\end{array}$ \\
\hline $\begin{array}{l}\text { Incomplete outcome data } \\
\text { (attrition bias) } \\
\text { All outcomes }\end{array}$ & Low risk & Attrition was low: $13 / 132$ dropouts \\
\hline
\end{tabular}

\section{Emmons 1988}

\begin{tabular}{ll}
\hline Methods & $\begin{array}{l}\text { Setting: cessation clinic, USA } \\
\text { Recruitment: community volunteers }\end{array}$ \\
\hline Participants & $\begin{array}{l}49 \text { smokers; } 71 \% \text { female, average age } 41 \text {, average cigs/day } 31 \text { (significant difference between groups, } \\
35 \text { vs } 27)\end{array}$ \\
\hline Interventions & $\begin{array}{l}\text { 1. Cessation programme with relapse prevention focus. } 8 \times 1 \frac{1}{2} \text { hours weekly, TQD between } 3 \text { and } 4 . \\
\text { pre-quit self-monitoring. Choice of 'cold turkey' or gradual reduction. Relaxation, role-play, cognitive } \\
\text { coping }\end{array}$
\end{tabular}


Emmons 1988 (Continued)

2. Broad-spectrum (BS) programme. $12 \times 1$ hour over 8 weeks. TQD between 3 and 4 . Included nicotine fading

\begin{tabular}{|c|c|c|}
\hline Outcomes & \multicolumn{2}{|c|}{$\begin{array}{l}\text { Abstinence at } 6 \text { months (point prevalence) (EOT and } 3 \text { months also reported) } \\
\text { Validation: saliva thiocyanate } \leq 85 \mathrm{microg} / \mathrm{mL}\end{array}$} \\
\hline Notes & \multicolumn{2}{|c|}{$\begin{array}{l}\text { Included in contact matched section, although different number of sessions } \\
\text { Inclusion of } 4 \text { non-completers would increase apparent benefit of BS }\end{array}$} \\
\hline \multicolumn{3}{|l|}{ Risk of bias } \\
\hline Bias & Authors' judgement & Support for judgement \\
\hline $\begin{array}{l}\text { Random sequence genera- } \\
\text { tion (selection bias) }\end{array}$ & Unclear risk & Randomisation in blocks, method not described \\
\hline $\begin{array}{l}\text { Allocation concealment } \\
\text { (selection bias) }\end{array}$ & Unclear risk & $\begin{array}{l}\text { No details given. Friends and relatives assigned to same condition, and signifi- } \\
\text { cant baseline differences between groups; BS smoked more }\end{array}$ \\
\hline $\begin{array}{l}\text { Blinding of participants } \\
\text { and personnel (perfor- } \\
\text { mance bias) } \\
\text { All outcomes }\end{array}$ & Low risk & $\begin{array}{l}\text { "Although facilitators knew that different treatments were being conducted, } \\
\text { they were unaware of the components of the alternate treatments". Same du- } \\
\text { ration of contact in both groups. Performance bias unlikely }\end{array}$ \\
\hline $\begin{array}{l}\text { Blinding of outcome as- } \\
\text { sessment (detection bias) } \\
\text { All outcomes }\end{array}$ & Low risk & Biochemically validated outcome \\
\hline $\begin{array}{l}\text { Incomplete outcome data } \\
\text { (attrition bias) } \\
\text { All outcomes }\end{array}$ & Unclear risk & $\begin{array}{l}\text { Results excluded } 4 \text { pretreatment dropouts, } 4 \text { non-completers ( } 3 \text { relapse pre- } \\
\text { vention, } 1 \mathrm{BS} \text { ), } 1 \text { medical problem }\end{array}$ \\
\hline
\end{tabular}

\section{Ershoff 1995}

$\begin{array}{ll}\text { Methods } & \text { Setting: HMO health centre, USA } \\ \text { Recruitment: pregnant women who had quit smoking since becoming pregnant }\end{array}$

\begin{tabular}{ll}
\hline Participants & $\begin{array}{l}171 \text { pregnant recent quitters, average length of prior abstinence } 31 \text { days, } 58 \% \text { had }>7 \text { days of total ab- } \\
\text { stinence } \\
\text { Average age } 25 \text {, average cigs/day } 10\end{array}$
\end{tabular}
Interventions 1. Relapse prevention self-help booklets; 4 on cessation given at baseline visit, 4 relapse preven- tion-oriented mailed at weekly intervals

\section{Control. 1-page tip sheet on behavioural techniques for avoiding relapse}
Both groups had a 2 minutes' discussion on smoking and pregnancy with health educator, were given 2-page pamphlet, congratulated on quitting

Point prevalence (7-day), late in $3 \mathrm{rd}$ trimester (also week 26 and week 34 of pregnancy)
Validation: cotinine, at least $1 \leq 10 \mathrm{ng} / \mathrm{mL}$ and none $\geq 80 \mathrm{ng} / \mathrm{mL}$

Notes $\quad 11 \%$ of women misreported abstinence

\section{Risk of bias}


Ershoff 1995 (Continued)

\begin{tabular}{lll} 
Bias & Authors' judgement & Support for judgement \\
\hline $\begin{array}{l}\text { Random sequence genera- } \\
\text { tion (selection bias) }\end{array}$ & Unclear risk & Randomisation method not described \\
\hline $\begin{array}{l}\text { Allocation concealment } \\
\text { (selection bias) }\end{array}$ & Low risk & $\begin{array}{l}\text { Allocation before participant contact, blind until end of baseline data collec- } \\
\text { tion }\end{array}$ \\
\hline $\begin{array}{l}\text { Blinding of participants } \\
\text { and personnel (perfor- } \\
\text { mance bias) } \\
\text { All outcomes }\end{array}$ & Low risk & $\begin{array}{l}\text { "The health educator was blind to group assignment until the end of data col- } \\
\text { lection... The program was presented as a standard part of prenatal care... Pa- } \\
\text { tients had no further contact with the prenatal intake health educator. Prena- } \\
\text { tal care providers were blind to group assignment, and no effort was made to } \\
\text { modify their usual counselling practices" }\end{array}$
\end{tabular}

\begin{tabular}{ll}
\hline Blinding of outcome as- & Low risk \\
sessment (detection bias) & \\
All outcomes & \\
\hline
\end{tabular}

Incomplete outcome data Low risk $\quad 37(22 \%)$ exclusions due to abortion, miscarriage, move from HMO

(attrition bias)

All outcomes

Evins 2014

\begin{tabular}{ll} 
Methods & Setting: community mental health centres, USA \\
& Recruitment: patients of mental health centres \\
\hline
\end{tabular}

Participants 87 ex-smokers (2 weeks abstinence), 40 varenicline plus CBT, 47 placebo plus CBT

$62 \%$ male, average age 47 , average cigs/day 23

Interventions Relapse prevention: varenicline pus CBT over a 40-week period

Control: placebo plus CBT over a 40-week period

\begin{tabular}{ll}
\hline Outcomes & Continuous abstinence at week 52 \\
Validation: $\mathrm{CO}<9$ ppm at week 52
\end{tabular}

\section{Notes}
Funding: "This study was funded by grants R01 DA021245 by National Institute on Drug Abuse with sup- plemental financial and material support from an investigator-initiated award from Pfizer for study medications and funding, and by 05B1MACMHS to the Massachusetts Department of Mental Health from the Department of Health and Human Services, Substance Abuse and Mental Health Services Ad- ministration, Treatment Strategies for Smoking Cessation in Patients with Schizophrenia to the North Suffolk Mental Health Association (Dr Evins). Pfizer provided study medication and supplemental sup- port through an investigator-initiated award after the protocol was approved by the institutional re- view board and the data and safety monitoring board."
Declaration of interest: see above - "The external funders had no role in design and conduct of the study; collection, management, analysis, and interpretation of the data; preparation, or approval of the manuscript; and decision to submit the manuscript for publication. At the time of submission and sole- ly as a courtesy, a copy of the manuscript was given to Pfizer, which offered neither edits nor approval to publish."

\section{Risk of bias}


Evins 2014 (Continued)

\begin{tabular}{lll} 
Bias & Authors' judgement & Support for judgement \\
\hline $\begin{array}{l}\text { Random sequence genera- } \\
\text { tion (selection bias) }\end{array}$ & Low risk & $\begin{array}{l}\text { Computerised randomisation used, stratified by study side and psychiatric dis- } \\
\text { order }\end{array}$ \\
\hline $\begin{array}{l}\text { Allocation concealment } \\
\text { (selection bias) }\end{array}$ & Low risk & $\begin{array}{l}\text { Not specified, but randomisation performed "by Massachusetts General Hospi- } \\
\text { tal research pharmacy staff members, who were not otherwise involved in the } \\
\text { trial, in double-blind fashion". }\end{array}$ \\
\hline $\begin{array}{l}\text { Blinding of participants } \\
\begin{array}{l}\text { and personnel (perfor- } \\
\text { mance bias) }\end{array}\end{array}$ & Low risk & Double-blind conditions \\
All outcomes &
\end{tabular}

\begin{tabular}{ll}
\hline Blinding of outcome as- & Low risk \\
sessment (detection bias) & \\
All outcomes &
\end{tabular}

Incomplete outcome data High risk 55\% follow-up rate in control compared to $88 \%$ in intervention
(attrition bias)

All outcomes

Fortmann 1995

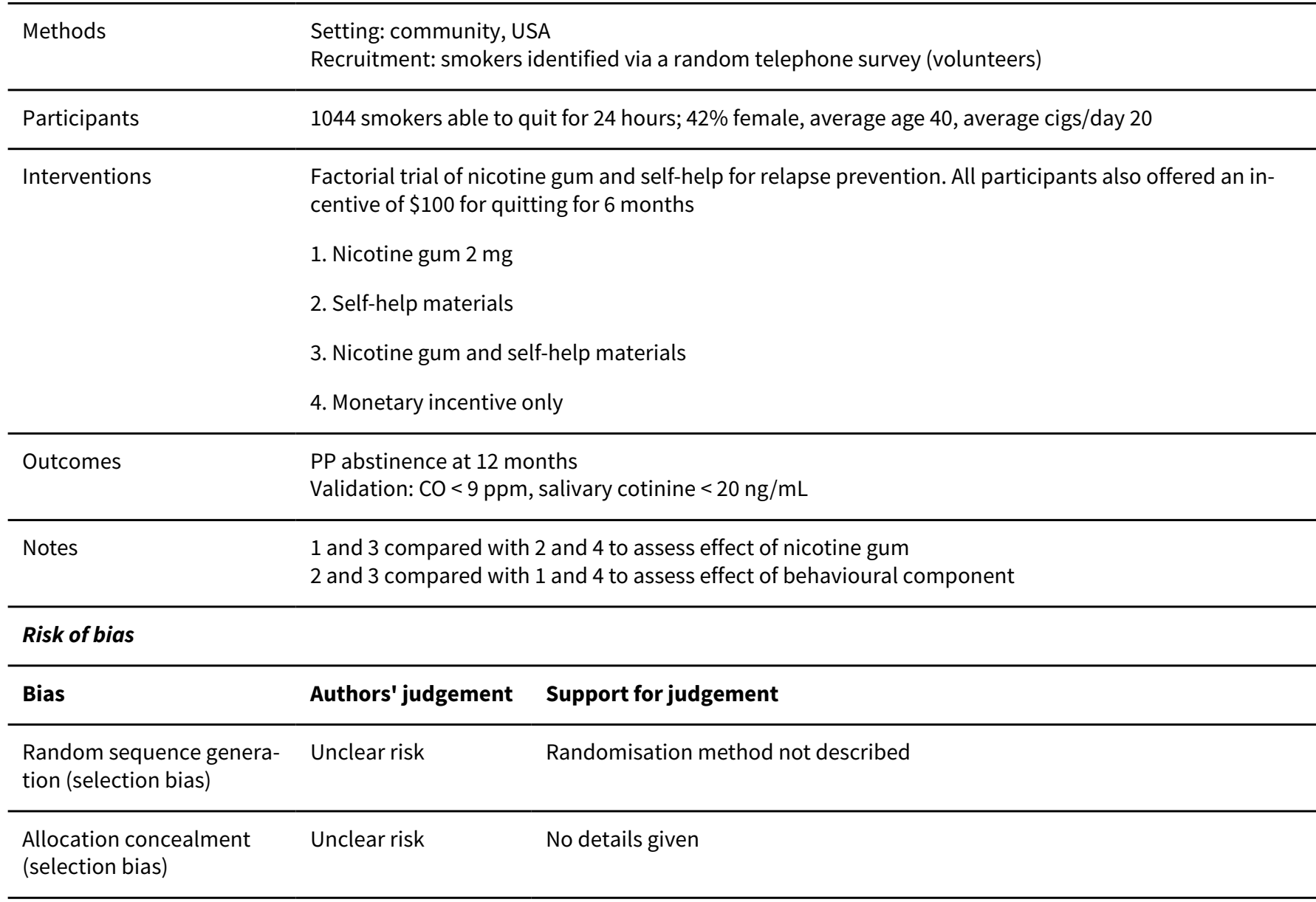


Fortmann 1995 (Continued)
Blinding of participants
Unclear risk
No details given and personnel (perfor- mance bias)
All outcomes

\begin{tabular}{lll}
\hline $\begin{array}{l}\text { Blinding of outcome as- } \\
\text { sessment (detection bias) }\end{array}$ & Low risk & Biochemical validation \\
All outcomes & \\
\hline $\begin{array}{l}\text { Incomplete outcome data } \\
\text { (attrition bias) } \\
\text { All outcomes }\end{array}$ & Low risk & $94 \%$ followed up at 12 months, all participants included in ITT analysis \\
\hline
\end{tabular}

Hajek 2001

\begin{tabular}{ll}
\hline Methods & $\begin{array}{l}\text { Setting: antenatal clinics, UK } \\
\text { Recruitment: pregnant smokers and recent quitters }\end{array}$ \\
\hline Participants & $\begin{array}{l}249 \text { pregnant recent (within } 6 \text { months) quitters, average abstinence } 7 \text { weeks (smokers also in trial, not } \\
\text { included for this review) } \\
\text { Average age } 28, \text { average cigs/day approximately } 12\end{array}$ \\
\hline Interventions & $\begin{array}{l}\text { 1. Advice from midwife with explanation of CO reading, pamphlet, prompt placed in notes for reinforce- } \\
\text { ment } \\
\text { 2. Usual midwife care }\end{array}$ \\
\hline Outcomes & $\begin{array}{l}\text { Abstinence at } 12 \text { months (prolonged for last } 12 \text { weeks of pregnancy and } 6 \text { months since birth), also at } \\
\text { birth } \\
\text { Validation: CO } \leq 10 \text { ppm }\end{array}$ \\
\hline
\end{tabular}

Notes

\section{Risk of bias}

\begin{tabular}{|c|c|c|}
\hline Bias & Authors' judgement & Support for judgement \\
\hline $\begin{array}{l}\text { Random sequence genera- } \\
\text { tion (selection bias) }\end{array}$ & Low risk & $\begin{array}{l}\text { Cluster randomised by midwife. "The allocation schedule was generated by } \\
\text { drawing of folded tags with Intervention or control designations and assigning } \\
\text { them to consecutive names on the list of midwives" }\end{array}$ \\
\hline $\begin{array}{l}\text { Allocation concealment } \\
\text { (selection bias) }\end{array}$ & High risk & $\begin{array}{l}\text { Randomised midwives were responsible for recruiting participants, fewer con- } \\
\text { trol midwives recruited any, so possible recruitment bias }\end{array}$ \\
\hline $\begin{array}{l}\text { Blinding of participants } \\
\text { and personnel (perfor- } \\
\text { mance bias) } \\
\text { All outcomes }\end{array}$ & Unclear risk & Not reported \\
\hline $\begin{array}{l}\text { Blinding of outcome as- } \\
\text { sessment (detection bias) } \\
\text { All outcomes }\end{array}$ & Low risk & Biochemically validated \\
\hline $\begin{array}{l}\text { Incomplete outcome data } \\
\text { (attrition bias) } \\
\text { All outcomes }\end{array}$ & Low risk & $\begin{array}{l}\text { Women who were untraceable or unsuitable for follow-up were excluded, oth- } \\
\text { er losses included as smokers }\end{array}$ \\
\hline
\end{tabular}


Hajek 2002

\begin{tabular}{ll}
\hline Methods & $\begin{array}{l}\text { Setting: } 17 \text { hospitals, UK } \\
\text { Recruitment: inpatients with MI or for CABG }\end{array}$ \\
\hline Participants & $\begin{array}{l}540 \text { smokers or recent quitters (26\%) who had not smoked since admission to hospital and motivated } \\
\text { to quit }\end{array}$ \\
\hline Interventions & $\begin{array}{l}\text { 1. As control + CO reading, booklet on smoking and cardiac recovery, written quiz, offer to find support } \\
\text { 'buddy', commitment, reminder in notes. Implemented by cardiac nurses during routine work, estimat- } \\
\text { ed time } 20 \text { months } \\
\text { 2. Verbal advice, 'Smoking and Your Heart' booklet }\end{array}$
\end{tabular}

Outcomes

Abstinence at 12 months, sustained (no more than 5 cigarettes since enrolment and 7-day PP) Validation: saliva cotinine $<20 \mathrm{ng} / \mathrm{mL}$ (CO used at 6 weeks follow-up and for visits at 12 months)

\section{Notes}

\section{Risk of bias}

\begin{tabular}{|c|c|c|}
\hline Bias & Authors' judgement & Support for judgement \\
\hline $\begin{array}{l}\text { Random sequence genera- } \\
\text { tion (selection bias) }\end{array}$ & Unclear risk & Randomisation method not described \\
\hline $\begin{array}{l}\text { Allocation concealment } \\
\text { (selection bias) }\end{array}$ & Low risk & $\begin{array}{l}\text { Nurses opened a "serially numbered, opaque, sealed envelope designating the } \\
\text { patient's allocation" }\end{array}$ \\
\hline $\begin{array}{l}\text { Blinding of participants } \\
\text { and personnel (perfor- } \\
\text { mance bias) } \\
\text { All outcomes }\end{array}$ & Unclear risk & Not reported, some contamination possible \\
\hline $\begin{array}{l}\text { Blinding of outcome as- } \\
\text { sessment (detection bias) } \\
\text { All outcomes }\end{array}$ & Low risk & Biochemical validation used \\
\hline $\begin{array}{l}\text { Incomplete outcome data } \\
\text { (attrition bias) } \\
\text { All outcomes }\end{array}$ & Low risk & $\begin{array}{l}26 \text { deaths and } 9 \text { moved. address excluded from denominator in analysis; all } \\
\text { others lost to follow-up counted as smokers }\end{array}$ \\
\hline
\end{tabular}

\section{Hall 1984}

\begin{tabular}{ll}
\hline Methods & $\begin{array}{l}\text { Setting: clinic, USA } \\
\text { Recruitment: media adverts and referral }\end{array}$ \\
\hline Participants & $\begin{array}{l}135 \text { smokers; } 59 \% \text { female, average age approximately } 36, \text { average cigs/day } 29 \\
\text { Therapists: } 2 \text { psychologists, randomly assigned to groups }\end{array}$ \\
\hline Interventions & $\begin{array}{l}\text { 2 } \times 2 \text { factorial trial, aversive smoking conditions collapsed } \\
\text { 1. Skills training, } 14 \times 75 \text { minute sessions. } 8 \text { sessions over } 3 \text { weeks involved } 6 \text { seconds or } 30 \text { seconds of } \\
\text { aversive smoking. } 6 \text { sessions over week } 1 \text { to } 6 \text { covered relaxation, commitment and cost benefits, and } \\
\text { relapse prevention skills with role-play of risk situations } \\
\text { 2. Discussion control. Same aversive smoking. Other } 6 \text { sessions used self-scoring tests and group dis- } \\
\text { cussion. Discussion of specific skills discouraged }\end{array}$
\end{tabular}


Hall 1984 (Continued)

Outcomes Abstinence at 12 months (point prevalence)

Validation: $\mathrm{CO}<10 \mathrm{ppm}$, plasma thiocyanate $<85 \mathrm{ng} / \mathrm{mg}$ and confirmation from significant other

Matched for contact time

Author tested for therapist and cohort main effects. None significant

\section{Risk of bias}

\begin{tabular}{lll}
\hline Bias & Authors' judgement & Support for judgement \\
\hline $\begin{array}{l}\text { Random sequence genera- } \\
\text { tion (selection bias) }\end{array}$ & Unclear risk & Randomisation method not described \\
\hline $\begin{array}{l}\text { Allocation concealment } \\
\text { (selection bias) }\end{array}$ & Unclear risk & No details given \\
\hline $\begin{array}{l}\text { Blinding of participants } \\
\text { and personnel (perfor- } \\
\text { mance bias) } \\
\text { All outcomes }\end{array}$ & Unclear risk & No details given \\
\hline $\begin{array}{l}\text { Blinding of outcome as- } \\
\text { sessment (detection bias) } \\
\text { All outcomes }\end{array}$ & Low risk & Biochemical validation used \\
\hline $\begin{array}{l}\text { Incomplete outcome data } \\
\text { (attrition bias) } \\
\text { All outcomes }\end{array}$ & Low risk & 8 dropouts from group 1 and 4 from group 2 before start of relapse prevention \\
\hline
\end{tabular}

Hall 1985

\begin{tabular}{ll}
\hline Methods & $\begin{array}{l}\text { Setting: clinic, USA } \\
\text { Recruitment: referred by physicians, friends or self }\end{array}$ \\
\hline Participants & $\begin{array}{l}84 \text { smokers in relevant arms; } 53 \% \text { male, average age } 38, \text { average cigs/day } 30.5 \\
\text { Therapists: } 2 \text { psychologists }\end{array}$ \\
\hline Interventions & $\begin{array}{l}\text { 1. Intensive behavioural treatment (including relapse prevention skill training, relaxation, } 30 \text { seconds } \\
\text { aversive smoking of } 3 \text { cigarettes). } 14 \times 75 \text { min sessions over } 8 \text { weeks } \\
\text { 2. Same as } 1 . \text { plus } 2 \text { mg nicotine gum available for } 6 \text { months } \\
\text { 3. Low-contact plus nicotine gum. Met } 4 \text { times in } 3 \text { weeks, educational materials, written exercises, } \\
\text { group discussion }\end{array}$
\end{tabular}

\begin{tabular}{ll}
\hline Outcomes & $\begin{array}{l}\text { Abstinence at } 52 \text { weeks (assume point prevalence) } \\
\text { Validation: } \mathrm{CO}<10 \mathrm{ppm} \text {, thiocyanate }<85 \mathrm{mg} / \mathrm{mL}, \text { reports of significant others (biochemical measures } \\
\text { failed to confirm self-report in } 3 \text { instances) }\end{array}$ \\
\hline Notes & $\begin{array}{l}2 \text { versus 3, not matched for contact time, controlled for gum. } 1 \text { not included in meta-analysis; 10/36 } \\
\text { quit }\end{array}$ \\
\hline
\end{tabular}

\section{Risk of bias}

Bias Authors' judgement Support for judgement


Hall 1985 (Continued)

Random sequence genera- Unclear risk Randomly assigned within time constraints, method not described tion (selection bias)

\begin{tabular}{lll}
\hline $\begin{array}{l}\text { Allocation concealment } \\
\text { (selection bias) }\end{array}$ & Unclear risk & No details given \\
\hline $\begin{array}{l}\text { Blinding of participants } \\
\text { and personnel (perfor- } \\
\text { mance bias) }\end{array}$ & High risk & No placebo NRT; no blinding. \\
All outcomes & \\
\hline
\end{tabular}

\begin{tabular}{lll}
$\begin{array}{l}\text { Blinding of outcome as- } \\
\text { sessment (detection bias) } \\
\text { All outcomes }\end{array}$ & Low risk & Biochemical validation used \\
\hline $\begin{array}{l}\text { Incomplete outcome data } \\
\text { (attrition bias) }\end{array}$ & Low risk & $\begin{array}{l}3 \text { dropouts in conditions } 1 \text { and } 2 \text { are assumed to be included in denominator } \\
\text { fll outcomes }\end{array}$
\end{tabular}

Hall 1987

\begin{tabular}{ll}
\hline Methods & $\begin{array}{l}\text { Setting: clinic, USA } \\
\text { Recruitment: community volunteers or referrals }\end{array}$ \\
\hline Participants & $\begin{array}{l}139 \text { smokers; } 53 \% \text { male, average age } 39 \text {, average cigs/day } 30 \\
\text { Therapists: advanced graduates in clinical psychology or health psychology }\end{array}$ \\
\hline Interventions & $\begin{array}{l}2 \times 2 \text { factorial trial. Nicotine gum/placebo arms collapsed } \\
1 . \text { Intensive behavioural treatment including } 6 \text { seconds aversive smoking, relapse prevention skills } \\
\text { training, written exercises. } 14 \times 75 \text { minute sessions (period not stated) } \\
2 . \text { 'Low contact', including written exercises, educational materials, group discussions, quitting tech- } \\
\text { niques. } 5 \times 60 \text { minutes }\end{array}$ \\
\hline Outcomes & $\begin{array}{l}\text { Abstinence at } 52 \text { weeks (assume point prevalence) } \\
\text { Validation: thiocyanate }<95 \text { mm/L (unless marijuana use reported), cO < } 8 \text { ppm, significant other }\end{array}$ \\
\hline Notes & $\begin{array}{l}\text { Not matched for contact time } \\
\text { No reported interaction between behaviour therapy condition and gum condition so gum/no gum col- } \\
\text { lapsed }\end{array}$ \\
\hline
\end{tabular}

\section{Risk of bias}

Bias Authors' judgement Support for judgement

Random sequence genera- Unclear risk $\quad$ Randomisation method not described
tion (selection bias)

\begin{tabular}{lll}
\hline $\begin{array}{l}\text { Allocation concealment } \\
\text { (selection bias) }\end{array}$ & Unclear risk & No details given \\
\hline $\begin{array}{l}\text { Blinding of participants } \\
\text { and personnel (perfor- } \\
\text { mance bias) }\end{array}$ & Unclear risk & $\begin{array}{l}\text { Placebo gum used but gum/no-gum conditions collapsed in meta-analysis. No } \\
\text { information provided re behavioural sessions in this domain }\end{array}$ \\
All outcomes & \\
\hline
\end{tabular}


Hall 1987 (Continued)

Blinding of outcome as- Low risk Biochemical validation used sessment (detection bias)

All outcomes

$\begin{array}{ll}\begin{array}{l}\text { Incomplete outcome data } \\ \text { (attrition bias) }\end{array} & \text { Low risk }\end{array}$

All outcomes

ditions were not statistically significant"

Hannöver 2009

\begin{tabular}{ll}
\hline Methods & $\begin{array}{l}\text { Setting: maternity services, Germany } \\
\text { Recruitment: postpartum women in maternity wards }\end{array}$ \\
\hline Participants & 304 women who had not smoked for 4 weeks at baseline assessment \\
\hline Interventions & $\begin{array}{l}\text { 1. Counselling using motivational interviewing. Face-to-face session } 40 \text { days postpartum, telephone } \\
\text { boosters } 4 \text { weeks and } 12 \text { weeks later } \\
\text { 2. Usual care from health system, self-help materials on postpartum smoking and partner smoking }\end{array}$
\end{tabular}

Outcomes

Sustained abstinence since birth of baby at 24 months (at 6 months, 12 months, PP also reported)

Validation: none

Notes Baseline assessment was conducted at median of 35 days after birth

\section{Risk of bias}

\begin{tabular}{|c|c|c|}
\hline Bias & Authors' judgement & Support for judgement \\
\hline $\begin{array}{l}\text { Random sequence genera- } \\
\text { tion (selection bias) }\end{array}$ & High risk & Alternation of screening forms \\
\hline $\begin{array}{l}\text { Allocation concealment } \\
\text { (selection bias) }\end{array}$ & High risk & $\begin{array}{l}\text { Alternate allocation done at study centre so not known to screener in advance, } \\
\text { reducing likelihood of selection bias }\end{array}$ \\
\hline $\begin{array}{l}\text { Blinding of participants } \\
\text { and personnel (perfor- } \\
\text { mance bias) } \\
\text { All outcomes }\end{array}$ & Unclear risk & $\begin{array}{l}\text { "The nature of the intervention made blinding impossible", but assessors } \\
\text { "were blind to the women's group membership" }\end{array}$ \\
\hline $\begin{array}{l}\text { Blinding of outcome as- } \\
\text { sessment (detection bias) } \\
\text { All outcomes }\end{array}$ & High risk & $\begin{array}{l}\text { Self-reported cessation only, intervention face-to-face and intensive compared } \\
\text { with control, differential misreport possible }\end{array}$ \\
\hline $\begin{array}{l}\text { Incomplete outcome data } \\
\text { (attrition bias) } \\
\text { All outcomes }\end{array}$ & Unclear risk & $\begin{array}{l}\text { Participants who revoked participation before baseline assessment were not } \\
\text { included in denominators }\end{array}$ \\
\hline
\end{tabular}

\section{Hasuo 2004}

$\begin{array}{ll}\text { Methods } & \text { Setting: hospital, Japan } \\ & \text { Recruitment: hospitalised volunteers, recently quit or expecting to quit in hospital }\end{array}$


Hasuo 2004 (Continued)

Interventions

1. In-hospital counselling from public health nurse, $3 \times 20$ min sessions, $+3 \times 5$ min calls, $7,21,42$ days postdischarge

2. Control: in-hospital counselling only

\begin{tabular}{ll}
\hline Outcomes & $\begin{array}{l}\text { Abstinence at } 12 \text { months (assume PP) } \\
\text { Validation: Urine cotinine }\end{array}$ \\
\hline Notes & New for 2009 update \\
\hline
\end{tabular}

\section{Risk of bias}

\begin{tabular}{lll}
\hline Bias & Authors' judgement & Support for judgement \\
\hline $\begin{array}{l}\text { Random sequence genera- } \\
\text { tion (selection bias) }\end{array}$ & Low risk & $\begin{array}{l}\text { Randomisation by computer stratified by smoking status, FTND and self-effica- } \\
\text { cy }\end{array}$ \\
\hline $\begin{array}{l}\text { Allocation concealment } \\
\text { (selection bias) }\end{array}$ & Low risk & Therapists notified of assignment after allocation \\
\hline
\end{tabular}

\begin{tabular}{|c|c|c|}
\hline $\begin{array}{l}\text { Blinding of participants } \\
\text { and personnel (perfor- } \\
\text { mance bias) } \\
\text { All outcomes }\end{array}$ & Low risk & $\begin{array}{l}\text { Public health nurse and participant did not know allocation until the day be- } \\
\text { fore discharge, so common treatment component unlikely to be affected by } \\
\text { performance bias }\end{array}$ \\
\hline
\end{tabular}

\begin{tabular}{lll}
\hline $\begin{array}{l}\text { Blinding of outcome as- } \\
\text { sessment (detection bias) } \\
\text { All outcomes }\end{array}$ & Unclear risk & Not clear whether results were self-report or cotinine-validated \\
\hline $\begin{array}{l}\text { Incomplete outcome data } \\
\begin{array}{l}\text { (attrition bias) } \\
\text { All outcomes }\end{array}\end{array}$ & Low risk & $\begin{array}{l}106 \text { excluded } 6 \text { deaths within } 12 \text { months and } 8 \text { who were smoking on day of } \\
\text { discharge, included all other losses }\end{array}$ \\
\hline
\end{tabular}

\section{Hayes 2018}

\begin{tabular}{ll}
\hline Methods & Setting: mailed intervention, USA \\
& Recruitment: via state telephone quitlines \\
\hline Participants & 577 smokers ( $>24$ hour abstinence), 286 intervention and 291 control \\
& $27 \%$ male, average age 37, average cigs/day: 10 to 20 \\
\hline Interventions & Relapse prevention: 'Smoke-free Kids' mailed parenting program \\
& Control: no treatment \\
\hline Outcomes & Va-day point prevalence at 3 years \\
& Validation: self-report only \\
\hline Notes & $\begin{array}{l}\text { Declaration of interests: "The author(s) declared no potential conflicts of interest with respect to the } \\
\text { research, authorship, and/or publication of this article." }\end{array}$ \\
\hline
\end{tabular}

\section{Risk of bias}


Hayes 2018 (Continued)

\begin{tabular}{|c|c|c|}
\hline Bias & Authors' judgement & Support for judgement \\
\hline $\begin{array}{l}\text { Random sequence genera- } \\
\text { tion (selection bias) }\end{array}$ & Unclear risk & Unclear how randomisation performed \\
\hline $\begin{array}{l}\text { Allocation concealment } \\
\text { (selection bias) }\end{array}$ & Unclear risk & Allocation unclear \\
\hline $\begin{array}{l}\text { Blinding of participants } \\
\text { and personnel (perfor- } \\
\text { mance bias) } \\
\text { All outcomes }\end{array}$ & Unclear risk & Blinding unclear \\
\hline $\begin{array}{l}\text { Blinding of outcome as- } \\
\text { sessment (detection bias) } \\
\text { All outcomes }\end{array}$ & Low risk & $\begin{array}{l}\text { Self-reported outcome only, but no face-to-face contact, hence differential } \\
\text { misreport judged unlikely }\end{array}$ \\
\hline $\begin{array}{l}\text { Incomplete outcome data } \\
\text { (attrition bias) } \\
\text { All outcomes }\end{array}$ & Low risk & $\begin{array}{l}\text { Quote: "Attrition status was not associated significantly with study group at ei- } \\
\text { ther follow-up point." }\end{array}$ \\
\hline
\end{tabular}

Hays 2001

\begin{tabular}{ll}
\hline Methods & $\begin{array}{l}\text { Setting: clinics, USA, } 5 \text { sites } \\
\text { Recruitment: } 784 \text { community volunteers for cessation and relapse prevention trial }\end{array}$ \\
\hline Participants & $\begin{array}{l}429 \text { abstainers (previously } \geq 15 \text { cigs/day) quit after } 7 \text { weeks open-label bupropion; } 51 \% \text { female, average } \\
\text { age } 46, \text { average cigs/day } 26\end{array}$ \\
\hline Interventions & $\begin{array}{l}\text { All participants first received } 7 \text { weeks bupropion, physician advice, self-help materials, and brief indi- } \\
\text { vidual counselling at follow-up visits to assist cessation } \\
\text { 1. Bupropion } 300 \mathrm{mg} / \text { day, } 45 \text { weeks }\end{array}$ \\
\hline 2. Placebo \\
\hline $\begin{array}{l}\text { Continuous abstinence at } 2 \text { years (1 year after EOT) } \\
\text { Validation: CO } \leq 10 \text { ppm }\end{array}$ \\
\hline Notes & $\begin{array}{l}\text { Quit rate after open-label phase was } 59 \%, \text { so the final quit rate of } 29 \% \text { in the bupropion group is equiv- } \\
\text { alent to } 17 \% \text { of people starting treatment }\end{array}$ \\
\hline
\end{tabular}

\section{Risk of bias}

\begin{tabular}{|c|c|c|}
\hline Bias & Authors' judgement & Support for judgement \\
\hline $\begin{array}{l}\text { Random sequence genera- } \\
\text { tion (selection bias) }\end{array}$ & Low risk & $\begin{array}{l}\text { "Randomization to the placebo or bupropion groups was computer generated } \\
\text { at a central location..." }\end{array}$ \\
\hline $\begin{array}{l}\text { Allocation concealment } \\
\text { (selection bias) }\end{array}$ & Low risk & Code held centrally, investigators blind \\
\hline $\begin{array}{l}\text { Blinding of participants } \\
\text { and personnel (perfor- } \\
\text { mance bias) } \\
\text { All outcomes }\end{array}$ & Low risk & $\begin{array}{l}\text { "...the investigators did not know the patient assignments. All bupropion and } \\
\text { placebo pills were identical in shape, size, and color" }\end{array}$ \\
\hline
\end{tabular}


Hays 2001 (Continued)

Blinding of outcome as- Low risk Blinding reported, and abstinence biochemically validated sessment (detection bias)

All outcomes

$\begin{array}{ll}\begin{array}{l}\text { Incomplete outcome data } \\ \text { (attrition bias) }\end{array} & \text { Low risk } \\ \text { All outcomes } & \begin{array}{l}74 \% \text { completed study, } 2 \text { deaths excluded, all other withdrawals included in ITT } \\ \text { analysis }\end{array}\end{array}$

Hays 2009

\begin{tabular}{ll} 
Methods & Setting: clinic, USA \\
& $\begin{array}{l}\text { Recruitment: } 195 \text { community volunteers for cessation and relapse prevention trial (110 included in re- } \\
\text { lapse prevention trial) }\end{array}$ \\
\hline Participants & $\begin{array}{l}110 \text { recovering alcoholic abstainers with at least } 1 \text { year continuous abstinence from alcohol and drugs, } \\
18+\text { years old, smoking at least } 20 \mathrm{cpd} \text { for previous year. Quit for at least last week of } 8 \text { weeks patch } \\
\text { therapy } \\
78 \% \text { male; average age } 44 \text {; average } \mathrm{cpd} 29.9 \text { (in initial population of } 195 \text { volunteers) }\end{array}$
\end{tabular}

Interventions
All participants first received brief weekly counselling sessions and nicotine patch for 8 weeks. Patch
tailored on the basis of baseline serum cotinine concentration
1. Bupropion: $150 \mathrm{mg} /$ day first $3 \mathrm{~d}$, then $300 \mathrm{mg} / \mathrm{d}$ until week 52
2. Placebo on same schedule
Brief individual counselling $(\leq 10 \mathrm{~min})$ at each clinic visit (weekly for week 9 to week 12 , monthly for
week 13 to week 24 , then at $52,53,64$, and 76 weeks)

\begin{tabular}{ll}
\hline Outcomes & Abstinence at 76 weeks (continuous and 7-d PP) \\
& Validation: $\mathrm{CO}<8 \mathrm{ppm}$ \\
\hline Notes & New for 2013 update \\
& $\begin{array}{l}\text { Study did not report number of participants allocated to each group or number of successful abstain- } \\
\text { ers in each group; numbers obtained through extrapolation } \\
\text { Authors contacted to clarify re discrepancy in } 76 \text { weeks data, but no response }\end{array}$
\end{tabular}

\section{Risk of bias}

\begin{tabular}{lll}
\hline Bias & Authors' judgement & Support for judgement \\
\hline $\begin{array}{l}\text { Random sequence genera- } \\
\text { tion (selection bias) }\end{array}$ & Unclear risk & "Randomized", method not stated \\
\hline $\begin{array}{l}\text { Allocation concealment } \\
\text { (selection bias) }\end{array}$ & Unclear risk & Method not described \\
\hline $\begin{array}{l}\text { Blinding of participants } \\
\text { and personnel (perfor- } \\
\text { mance bias) } \\
\text { All outcomes }\end{array}$ & Unclear risk & Described as "double-blind", placebo used, but no further information given \\
\hline
\end{tabular}


Hays 2009 (Continued)
Blinding of outcome as-
Low risk
Smoking status biochemically validated sessment (detection bias)

All outcomes

\begin{tabular}{|c|c|c|}
\hline $\begin{array}{l}\text { Incomplete outcome data } \\
\text { (attrition bias) } \\
\text { All outcomes }\end{array}$ & Low risk & $\begin{array}{l}\text { At week } 76 \text {, similar rate of dropout in both groups ( } 34 \% \text { intervention; } 37 \% \text { con- } \\
\text { trol). Participants lost to follow-up counted as relapsed smokers }\end{array}$ \\
\hline Other bias & Unclear risk & Discrepancy in data: at 76 weeks, 7 -d PP less than continuous abstinence \\
\hline
\end{tabular}

Hicks 2017

\begin{tabular}{ll}
\hline Methods & Setting: mobile app, USA \\
& Recruitment: not specified, patients with chronic PTSD
\end{tabular}

Participants $\begin{aligned} & 11 \text { smokers, } 5 \text { intervention and } 6 \text { control } \\ & \text { Patients with chronic PTSD, 36.4\% male, average age 53, average cigs/day } 17\end{aligned}$

Interventions

Relapse prevention: QUIT4EVER where Stay Quit Coach app tailored to patients with chronic PTSD preinstalled on provided mobile phones in addition to control app

Control: Contingency management app pre-installed on provided mobile phones

\begin{tabular}{|c|c|}
\hline Outcomes & $\begin{array}{l}\text { 7-day point prevalence at } 6 \text { months } \\
\text { Validation: Cotinine }<10 \mathrm{ng} / \mathrm{mL}\end{array}$ \\
\hline Notes & $\begin{array}{l}\text { Funding: "Duke University School of Medicine Bridge Funding Program, and the National Cancer In- } \\
\text { stitute (R01CA196304- 02S1), Veterans Affairs Office of Academic Affiliations Advanced Fellowship } \\
\text { Program in Mental Illness Research and Treatment, and U.S. Department of Veterans Affairs Clinical } \\
\text { Sciences Research and Development Senior Research Career Scientist Award (1lK6CX001494)." } \\
\text { Declaration of interests: "The authors have no competing financial interests to report" } \\
\text { 6-month results for control group provided by correspondence with study authors }\end{array}$ \\
\hline
\end{tabular}

\section{Risk of bias}

\begin{tabular}{lll}
\hline Bias & Authors' judgement & Support for judgement \\
\hline $\begin{array}{l}\text { Random sequence genera- } \\
\text { tion (selection bias) }\end{array}$ & Low risk & Computer randomisation performed \\
\hline $\begin{array}{l}\text { Allocation concealment } \\
\text { (selection bias) }\end{array}$ & Unclear risk & Concealment not specified \\
\hline $\begin{array}{l}\text { Blinding of participants } \\
\begin{array}{l}\text { and personnel (perfor- } \\
\text { mance bias) }\end{array}\end{array}$ & Unclear risk & Blinding unclear \\
$\begin{array}{l}\text { All outcomes } \\
\text { Blinding of outcome as- } \\
\text { sessment (detection bias) } \\
\text { All outcomes }\end{array}$ & Low risk & \\
\hline
\end{tabular}


Hicks 2017 (Continued)

Incomplete outcome data High risk 50\% dropout in control vs $20 \%$ from intervention (attrition bias)

All outcomes

Hurt 2003

$\begin{array}{ll}\text { Methods } & \text { Setting: clinics, USA, } 14 \text { sites } \\ & \text { Recruitment: } 578 \text { community volunteers for cessation and relapse prevention trial }\end{array}$

Participants

176 abstainers (previously $\geq 15$ cigs/day) quit after 8 weeks of nicotine patch; baseline group: $57 \%$ female, average age 42 , average cigs/day 26

Interventions

All participants first received nicotine patch for 8 weeks at a dose of 22, 33 or $44 \mathrm{mg} /$ day, matched to baseline cigs/day. Brief advice to quit and self-help materials but no formal counselling

1. Bupropion $300 \mathrm{mg} /$ day for 6 months

2. Placebo

No additional counselling during maintenance phase

\begin{tabular}{ll}
\hline Outcomes & $\begin{array}{l}\text { Abstinence at } 12 \text { months (PP) (6 months after EOT). } \\
\text { Validation: CO }<8 \mathrm{ppm}\end{array}$ \\
\hline Notes & $\begin{array}{l}\text { Quit rate after open-label phase was } 31 \% \text {, so the final quit rate of } 22 \% \text { in the bupropion group is equiv- } \\
\text { alent to } 7 \% \text { of people starting treatment }\end{array}$ \\
\hline
\end{tabular}

\section{Risk of bias}

\section{Bias}

Authors' judgement Support for judgement

Random sequence genera- Unclear risk tion (selection bias)

Randomised by 'dynamic allocation', stratified on sex, cigs/day and years of smoking

\begin{tabular}{l}
$\begin{array}{l}\text { Allocation concealment } \\
\text { (selection bias) }\end{array} \quad$ Unclear risk Not explicit, although randomisation procedure made concealment probable \\
\hline
\end{tabular}

\begin{tabular}{|c|c|c|}
\hline $\begin{array}{l}\text { Blinding of participants } \\
\text { and personnel (perfor- } \\
\text { mance bias) } \\
\text { All outcomes }\end{array}$ & Unclear risk & Described as "double-blind", placebo used, but no further information given \\
\hline $\begin{array}{l}\text { Blinding of outcome as- } \\
\text { sessment (detection bias) } \\
\text { All outcomes }\end{array}$ & Low risk & Biochemical validation used \\
\hline $\begin{array}{l}\text { Incomplete outcome data } \\
\text { (attrition bias) } \\
\text { All outcomes }\end{array}$ & Unclear risk & $\begin{array}{l}\text { All participants lost to follow-up counted as smokers, but numbers not provid- } \\
\text { ed }\end{array}$ \\
\hline
\end{tabular}

\section{Japuntich 2006}

\begin{tabular}{ll}
\hline Methods & Setting: clinic/internet, USA \\
& Recruitment: community volunteers
\end{tabular}


Japuntich 2006 (Continued) Interventions
All participants received bupropion ( $300 \mathrm{mg}$ ) for 9 weeks, 3 brief ( $20 \mathrm{mins}$ ) individual counselling sessions, 5 clinic visits for assessment, monthly assessment calls

1. Access to Comprehensive Health Enhancement Support System for Smoking Cessation and Relapse Prevention (CHESS SCRP) for 12 weeks, computer and access provided, daily use recommended, reminders to log on up to 3 times a week

2. No additional support

\begin{tabular}{ll}
\hline Outcomes & $\begin{array}{l}\text { Abstinence at } 6 \text { months (PP) } \\
\text { Validation: } \mathrm{CO} \leq 10 \mathrm{ppm}\end{array}$ \\
\hline Notes & New for 2009 update \\
& 12 -month follow-up results not published \\
\hline
\end{tabular}

\section{Risk of bias}

\begin{tabular}{|c|c|c|}
\hline Bias & Authors' judgement & Support for judgement \\
\hline $\begin{array}{l}\text { Random sequence genera- } \\
\text { tion (selection bias) }\end{array}$ & Unclear risk & Randomisation method not described \\
\hline $\begin{array}{l}\text { Allocation concealment } \\
\text { (selection bias) }\end{array}$ & Unclear risk & No details given \\
\hline $\begin{array}{l}\text { Blinding of participants } \\
\text { and personnel (perfor- } \\
\text { mance bias) } \\
\text { All outcomes }\end{array}$ & Low risk & $\begin{array}{l}\text { No details given, but as support provided to both groups pre-intervention, and } \\
\text { not during intervention period, performance bias unlikely }\end{array}$ \\
\hline $\begin{array}{l}\text { Blinding of outcome as- } \\
\text { sessment (detection bias) } \\
\text { All outcomes }\end{array}$ & Low risk & Biochemical validation used \\
\hline $\begin{array}{l}\text { Incomplete outcome data } \\
\text { (attrition bias) } \\
\text { All outcomes }\end{array}$ & Low risk & $\begin{array}{l}20 \% \text { losses to follow-up and intervention participants who didn't get comput- } \\
\text { er included in ITT analysis }\end{array}$ \\
\hline
\end{tabular}

Joseph 2011

\begin{tabular}{ll}
\hline Methods & Setting: Minnesota, USA \\
& Recruitment: community volunteers (via local labour unions) \\
\hline Participants & 443 adult smokers of at least 5 cpd interested in quitting in next $14 \mathrm{~d}$ \\
& $60.2 \%$ female, average age 42, average cpd 17.7
\end{tabular}

Interventions

All participants received 5 telephone calls and NRT (patch; gum; lozenge, provision modelled on common clinical practice) by mail for 4 weeks. Randomly assigned to:

1. Longitudinal care modelled on chronic disease mgmt approach. Telephone counselling and NRT by mail for additional 48 weeks. Counsellors aimed to call every 2 weeks but adjustment based on participants' progress/receptivity; if participants chose not to make a quit attempt or reduce, calls made monthly

2. Usual care. 1 additional call at 8 weeks 
Joseph 2011 (Continued)

Validation: none

Notes New for 2013 update

Number abstinent not provided, extrapolated from percentages given

Risk of bias

\begin{tabular}{lll}
\hline Bias & Authors' judgement & Support for judgement \\
\hline $\begin{array}{l}\text { Random sequence genera- } \\
\text { tion (selection bias) }\end{array}$ & Low risk & $\begin{array}{l}\text { "Participants were randomly assigned... by a computer-generated scheme, } \\
\text { blocked in masked groups of 20" }\end{array}$ \\
\hline $\begin{array}{l}\text { Allocation concealment } \\
\text { (selection bias) }\end{array}$ & Low risk & $\begin{array}{l}\text { "The randomization schedule was maintained by personnel independent from } \\
\text { the study" }\end{array}$ \\
\hline $\begin{array}{l}\text { Blinding of participants } \\
\text { and personnel (perfor- } \\
\text { mance bias) }\end{array}$ & Unclear risk & $\begin{array}{l}\text { Not specified, allocation occurred before end of common treatment compo- } \\
\text { nent }\end{array}$ \\
\hline $\begin{array}{l}\text { Blinding of outcome as- } \\
\text { sessment (detection bias) } \\
\text { All outcomes }\end{array}$ & Low risk & $\begin{array}{l}\text { Self-reported outcome only, but no face-to-face contact, hence differential } \\
\text { misreport judged unlikely }\end{array}$ \\
\hline $\begin{array}{l}\text { Incomplete outcome data } \\
\text { (attrition bias) } \\
\begin{array}{l}\text { All outcomes } \\
\hline\end{array}\end{array}$ & Low risk & $\begin{array}{l}\text { Low and similar rates of loss to follow-up in both groups (8.6\% intervention, } \\
8.1 \% \text { control); dropouts counted as smokers in ITT analysis }\end{array}$ \\
\hline
\end{tabular}

Killen 1984

\begin{tabular}{ll} 
Methods & $\begin{array}{l}\text { Setting: clinic, USA } \\
\text { Recruitment: community volunteers }\end{array}$ \\
\hline Participants & $\begin{array}{l}64 \text { smokers ( } 44 \text { in relevant arms); } 72 \% \text { female, average age 44, average cigs/day } 32 \\
\text { Behaviour therapy provided by } 2 \text { psychologists, } 1 \text { medical social worker, assigned randomly to treat- } \\
\text { ment conditions, group size } 10 \text { to } 12\end{array}$ \\
\hline Interventions & $\begin{array}{l}\text { All participated in cessation training (including cognitive-behavioural skills training and an aversive } \\
\text { smoke-holding procedure), } 4 \times 1 \frac{1}{2} \text { hour sessions over } 4 \text { days, in groups of } 10 \text { to } 12 \\
\text { 1. Nicotine gum ( } 2 \text { mg) for } 7 \text { weeks } \\
\text { 2. Skills training for relapse prevention. } 2 \text { sessions in } 2 \text { weeks, then } 4 \text { weekly drop-in sessions. Included } \\
\text { identification of high-risk situations and coping strategies, homework } \\
\text { 3. Combined } 1 \text { and } 2\end{array}$ \\
\hline
\end{tabular}

Outcomes

Abstinence for 4 weeks at $10 \frac{1}{2}$ months after quit date

Validation: $\mathrm{CO}<8$ ppm (2 people unable to attend assessment, based on self-report), Serum thio-

cyanate measured at 6 weeks only
Notes
3 versus 1 for effect of relapse prevention component over NRT alone 3 versus 2 tests for effect of NRT for initial cessation, not included

\section{Risk of bias}

Bias Authors' judgement Support for judgement


Killen 1984 (Continued)

$\begin{array}{ll}\begin{array}{l}\text { Random sequence genera- } \\ \text { tion (selection bias) }\end{array} & \begin{array}{l}\text { Randomisation method not described (married couples allocated to same } \\ \text { condition) }\end{array}\end{array}$
tion (selection bias) condition

$\begin{array}{lll}\begin{array}{l}\text { Allocation concealment } \\ \text { (selection bias) }\end{array} & \text { Unclear risk details given }\end{array}$

\begin{tabular}{|c|c|c|}
\hline $\begin{array}{l}\text { Blinding of participants } \\
\text { and personnel (perfor- } \\
\text { mance bias) } \\
\text { All outcomes }\end{array}$ & High risk & $\begin{array}{l}\text { No blinding reported. "Interpretation of this data is hampered by the lack of a } \\
\text { placebo control condition". Unclear whether therapists aware of gum alloca- } \\
\text { tion }\end{array}$ \\
\hline
\end{tabular}

\begin{tabular}{lll}
\hline Blinding of outcome as- & Low risk & Biochemical validation used \\
sessment (detection bias)
\end{tabular}

All outcomes

Incomplete outcome data Unclear risk Losses to follow-up not reported, all participants included
(attrition bias)

(attrition bias)

All outcomes

Killen 1990

\begin{tabular}{|c|c|}
\hline Methods & $\begin{array}{l}\text { Setting: community, USA (Stanford Stop Smoking Project) } \\
\text { Recruitment: media advertisements for volunteers for self-help relapse prevention research pro- } \\
\text { gramme. To be eligible for randomisation, had to have quit for } 48 \text { hours unaided. (Quit validated by CO } \\
<9 \mathrm{ppm} \text { ) }\end{array}$ \\
\hline Participants & 1218 smokers who had quit for 48 hours; 52\% female, average age 43, average cigs/day 25 \\
\hline Interventions & $\begin{array}{l}4 \times 3 \text { factorial design crossing gum and self-help conditions: } \\
\text { Nicotine gum ( } 2 \mathrm{mg} \text { ) conditions: } \\
\text { 1. Ad lib schedule, whenever strong need to smoke } \\
\text { 2. Fixed schedule ( } 1 \text { piece/hour for at least } 12 \text { hours/day) } \\
\text { 3. Placebo gum } \\
\text { 4. No gum } \\
\text { Self-help intervention was based on } 16 \text { specially written modules. All participants were given the first } \\
\text { 'How to cope with the urge to smoke without smoking' booklet. Then randomly assigned to: } \\
\text { - Self-selected: chose } 7 \text { more to receive in weekly mailings } \\
\text { - Random: sent } 7 \text { modules at random } \\
\text { - No modules: no further contact }\end{array}$ \\
\hline Outcomes & $\begin{array}{l}\text { Abstinence at } 12 \text { months (7-day point prevalence) } \\
\text { Validation: saliva cotinine }<20 \mathrm{ng} / \mathrm{mL} \text {, except for participants who had moved away }\end{array}$ \\
\hline Notes & Quit rates for module/no module conditions provided by authors. Gum conditions collapsed \\
\hline \multicolumn{2}{|l|}{ Risk of bias } \\
\hline Bias & Support for judgement \\
\hline
\end{tabular}


Killen 1990 (Continued)

Random sequence genera- Unclear risk $\quad$ Randomisation method not stated
tion (selection bias)

\begin{tabular}{lll}
\hline $\begin{array}{l}\text { Allocation concealment } \\
\text { (selection bias) }\end{array}$ & Unclear risk & No details given \\
\hline $\begin{array}{l}\text { Blinding of participants } \\
\text { and personnel (perfor- } \\
\text { mance bias) }\end{array}$ & Unclear risk & $\begin{array}{l}\text { "Assignment to gum condition was double-blind" but further information not } \\
\text { provided }\end{array}$
\end{tabular}

mance bias)

All outcomes

\author{
Blinding of outcome as- Low risk Treatment condition blinded, biochemical validation used \\ sessment (detection bias) \\ All outcomes
}

Incomplete outcome data Unclear risk Losses to follow-up not reported, all participants included except 8 deaths
(attrition bias)

All outcomes

Killen 2006

\begin{tabular}{|c|c|}
\hline Methods & $\begin{array}{l}\text { Setting: clinic, USA } \\
\text { Recruitment: community volunteers }\end{array}$ \\
\hline Participants & $\begin{array}{l}362 \text { smokers } \geq 10 \text { cigs/day, no current major depression } \\
46 \% \text { female, average age } 45 \text {, average cigs/day } 20,25 \% \text { previous bupropion use }\end{array}$ \\
\hline Interventions & $\begin{array}{l}\text { All participants received open-label combination pharmacotherapy of bupropion } 300 \mathrm{mg} \text { for } 11 \text { weeks, } \\
\text { nicotine patch for } 10 \text { weeks. TQD day } 7,30 \text {-min individual relapse prevention skills training at } 6 \text { clinic } \\
\text { visits } \\
\text { 1. Bupropion } 150 \mathrm{mg} \text { for } 14 \text { weeks } \\
\text { 2. } 2 \text { weeks tapering bupropion, then placebo } \\
\text { Both arms had } 4 \text { further clinic visits during extended therapy }\end{array}$ \\
\hline
\end{tabular}

\begin{tabular}{ll}
\hline Outcomes & $\begin{array}{l}\text { Abstinence at } 12 \text { months (6 months post-EOT) (continuous). PP and 7-day relapse-free outcomes also } \\
\text { reported } \\
\text { Validation: CO (10 people not required to provide samples) }\end{array}$
\end{tabular}

\begin{tabular}{ll}
\hline Notes & New for 2009 update \\
PP outcomes favoured placebo, but no outcomes showed significant effects \\
Approximately $52 \%$ were quit at the end of baseline therapy
\end{tabular}

\title{
Risk of bias
}

\begin{tabular}{lll}
\hline Bias & Authors' judgement & Support for judgement \\
\hline $\begin{array}{l}\text { Random sequence genera- } \\
\text { tion (selection bias) }\end{array}$ & Low risk & Preassigned random sequence stratified by gender, before open-label phase \\
\hline $\begin{array}{l}\text { Allocation concealment } \\
\text { (selection bias) }\end{array}$ & Low risk & Not explicitly concealed but judged probable that it was \\
\hline $\begin{array}{l}\text { Blinding of participants } \\
\text { and personnel (perfor- } \\
\text { mance bias) }\end{array}$ & Low risk & $\begin{array}{l}\text { Blinded drugs provided to investigator; "... [the pharmaceutical company]... } \\
\text { packaged the treatment and then shipped the blinded drug to the investiga- } \\
\text { tor" }\end{array}$ \\
\hline
\end{tabular}


Killen 2006 (Continued)

All outcomes

Blinding of outcome as-
sessment (detection bias) $\quad$ Low risk Treatment condition blinded, biochemical validation used

sessment (detection bias)

All outcomes

Incomplete outcome data Low risk $\quad 10 \%$ lost to follow-up, included in ITT analysis

(attrition bias)

All outcomes

Klesges 1999

\begin{tabular}{ll}
\hline Methods & $\begin{array}{l}\text { Setting: Air Force, USA } \\
\text { Recruitment: recruits undergoing basic military training (BMT) }\end{array}$ \\
\hline Participants & $\begin{array}{l}18,010 \text { recruits, 29\% regular smokers before enforced abstinence during training. 28\% female, average } \\
\text { age } 20\end{array}$ \\
\hline Interventions & $\begin{array}{l}\text { 1. Single 50-min intervention during final week of training, 50/group, including non-smokers. Discussed } \\
\text { health effects, costs, social impact, role-play } \\
\text { 2. Control: general health video } \\
\text { All participants exposed to } 6 \text { weeks smoking ban and shown 2 videos to preview primary intervention }\end{array}$ \\
\hline Outcomes & $\begin{array}{l}\text { Abstinence at } 12 \text { months (not defined) } \\
\text { Validation: none } \\
\text { Relapse amongst baseline ex-smokers and initiation amongst non-smokers also reported }\end{array}$ \\
\hline Notes & $\begin{array}{l}\text { Results not displayed graphically because denominators not explicit. No significant overall benefit. ICC } \\
\text { small (0.004 for smokers) }\end{array}$
\end{tabular}

\section{Risk of bias}

\begin{tabular}{|c|c|c|}
\hline Bias & Authors' judgement & Support for judgement \\
\hline $\begin{array}{l}\text { Random sequence genera- } \\
\text { tion (selection bias) }\end{array}$ & Unclear risk & $\begin{array}{l}\text { Cluster-randomised by training flight. } 75 \% \text { assigned to intervention, method } \\
\text { of sequence generation not specified }\end{array}$ \\
\hline $\begin{array}{l}\text { Allocation concealment } \\
\text { (selection bias) }\end{array}$ & Low risk & $\begin{array}{l}\text { Not specified, but training flight allocation was independent of this trial, so po- } \\
\text { tential for bias small }\end{array}$ \\
\hline $\begin{array}{l}\text { Blinding of participants } \\
\text { and personnel (perfor- } \\
\text { mance bias) } \\
\text { All outcomes }\end{array}$ & Unclear risk & $\begin{array}{l}\text { No blinding reported, control knowledge of intervention unclear, personnel } \\
\text { knowledge of participant assignment not reported }\end{array}$ \\
\hline $\begin{array}{l}\text { Blinding of outcome as- } \\
\text { sessment (detection bias) } \\
\text { All outcomes }\end{array}$ & Low risk & $\begin{array}{l}\text { Although no biochemical validation used, intervention was of low intensity } \\
\text { with limited face-to-face contact, sample size was large, follow-up rate was } \\
\text { high and self-report was via survey. Risk of differential misreport was low }\end{array}$ \\
\hline $\begin{array}{l}\text { Incomplete outcome data } \\
\text { (attrition bias) } \\
\text { All outcomes }\end{array}$ & Low risk & $96 \%$ of available smokers reached \\
\hline
\end{tabular}


Klesges 2006

\begin{tabular}{ll}
\hline Methods & $\begin{array}{l}\text { Setting: Air Force, USA } \\
\text { Recruitment: recruits undergoing basic military training (BMT) }\end{array}$ \\
\hline Participants & Subgroup of 7525 regular smokers in intervention and 2639 in control \\
\hline Interventions & $\begin{array}{l}\text { 1. Two } 1 \text { hour sessions during week } 6 \text { of BMT, emphasis on discrepancy between Air Force ideals and } \\
\text { smoking. Barriers, role-playing. One sheet of NRT gum ailable for use at end of training } \\
\text { 2. Same schedule, health-related and first aid videos }\end{array}$ \\
\hline Outcomes & $\begin{array}{l}\text { Abstinence at } 1 \text { year (sustained from end of BMT) } \\
\text { Validation: none }\end{array}$ \\
\hline
\end{tabular}

Notes

\section{Risk of bias}

\begin{tabular}{|c|c|c|}
\hline Bias & Authors' judgement & Support for judgement \\
\hline $\begin{array}{l}\text { Random sequence genera- } \\
\text { tion (selection bias) }\end{array}$ & Unclear risk & $\begin{array}{l}\text { Cluster-randomised by training flight. } 75 \% \text { assigned to intervention, method } \\
\text { of sequence generation not specified }\end{array}$ \\
\hline $\begin{array}{l}\text { Allocation concealment } \\
\text { (selection bias) }\end{array}$ & Low risk & $\begin{array}{l}\text { Not specified, but training flight allocation was independent of this trial, so po- } \\
\text { tential for bias small }\end{array}$ \\
\hline $\begin{array}{l}\text { Blinding of participants } \\
\text { and personnel (perfor- } \\
\text { mance bias) } \\
\text { All outcomes }\end{array}$ & Unclear risk & Not specified \\
\hline $\begin{array}{l}\text { Blinding of outcome as- } \\
\text { sessment (detection bias) } \\
\text { All outcomes }\end{array}$ & High risk & $\begin{array}{l}\text { Staff who conducted follow-ups were not blinded to treatment assignment at } \\
\text { follow-up; differential follow-up possible for participants who did not respond } \\
\text { to survey and were contacted by telephone }\end{array}$ \\
\hline $\begin{array}{l}\text { Incomplete outcome data } \\
\text { (attrition bias) } \\
\text { All outcomes }\end{array}$ & Unclear risk & $\begin{array}{l}\text { Random subgroup targeted for follow-up, } 86 \% \text { reached. People lost to fol- } \\
\text { low-up excluded because likely to be missing completely at random }\end{array}$ \\
\hline
\end{tabular}

Lando 1996

\begin{tabular}{ll} 
Methods & $\begin{array}{l}\text { Setting: community, USA } \\
\text { Recruitment: community volunteers }\end{array}$ \\
\hline Participants & $\begin{array}{l}1083 \text { smokers who attended a smoking cessation clinic; } 60 \% \text { female, average age 45, average cigs/day } \\
27\end{array}$ \\
\hline Interventions & $\begin{array}{l}\text { All participated in 15-session 8-week group cessation programme } \\
\text { 1. Telephone counselling at 3, 9, } 21 \text { months. At each point, up to } 3 \text { calls could be made if requested } \\
\text { 2. Control. No additional contact }\end{array}$ \\
\hline Outcomes & $\begin{array}{l}\text { Abstinence at } 34 \text { months (12 months after EOT (7-day point prevalence)). Also assessed at } 6,12, \text { and } 24 \\
\text { months } \\
\text { Validation: random half of quitters validated by saliva cotinine }<20 \mathrm{ng} / \mathrm{mL} \text { at } 12 \text { months } 91 \% \text { con- } \\
\text { firmed }\end{array}$ \\
\hline
\end{tabular}

Notes 
Lando 1996 (Continued)

Risk of bias

\begin{tabular}{|c|c|c|}
\hline Bias & Authors' judgement & Support for judgement \\
\hline $\begin{array}{l}\text { Random sequence genera- } \\
\text { tion (selection bias) }\end{array}$ & Unclear risk & Randomisation method not described \\
\hline $\begin{array}{l}\text { Allocation concealment } \\
\text { (selection bias) }\end{array}$ & Unclear risk & No details given \\
\hline $\begin{array}{l}\text { Blinding of participants } \\
\text { and personnel (perfor- } \\
\text { mance bias) } \\
\text { All outcomes }\end{array}$ & Unclear risk & $\begin{array}{l}\text { Unclear whether counsellors for group sessions were aware of participant allo- } \\
\text { cation. Unclear if control group was aware of additional support offered to in- } \\
\text { tervention group }\end{array}$ \\
\hline $\begin{array}{l}\text { Blinding of outcome as- } \\
\text { sessment (detection bias) } \\
\text { All outcomes }\end{array}$ & Low risk & $\begin{array}{l}\text { Biochemical validation used in subsample with low level of discrepancies indi- } \\
\text { cated, "difference between the intervention and comparison conditions in dis- } \\
\text { confirmation was not significant" }\end{array}$ \\
\hline $\begin{array}{l}\text { Incomplete outcome data } \\
\text { (attrition bias) } \\
\text { All outcomes }\end{array}$ & Low risk & $>95 \%$ reached at each follow-up, all participants included in analysis \\
\hline
\end{tabular}

Levine 2016

$\begin{array}{ll}\text { Methods } & \text { Setting: clinic and home-based, USA } \\ & \text { Recruitment: prenatal smoking cessation programs, obstetric and paediatric offices and women's } \\ & \text { health clinics }\end{array}$
health clinics

Participants 300 ex-smokers (abstinence $>2$ weeks), 150 in each group

Pregnant women, average age 25, average cigs/day 11

Interventions Relapse prevention: 'STARTS' enhanced cognitive behavioural intervention

Control: 'SUPPORT' supportive, time and attention-controlled comparison

Outcomes Sustained abstinence at 52 weeks postpartum

Validation: $\mathrm{CO}<8 \mathrm{ppm}$ or cotinine $15 \mathrm{ng} / \mathrm{mL}$ at 52 weeks postpartum

Notes $\quad$ Funding: "Support for this trial was provided by grant R01DA021608 (principal investigator Dr Levine) from the National Institute on Drug Abuse. Role of the Funder/Sponsor: The National Institute on Drug Abuse had no role in the design and conduct of the study; collection, management, analysis, or interpretation of the data; preparation of the manuscript for publication; or decision to submit the manuscript for publication."

Declaration of interests: "Dr Marcus reported serving on the scientific advisory board of Weight Watchers International, Inc. No other disclosures were reported."

\section{Risk of bias}

Bias Authors' judgement Support for judgement


Levine 2016 (Continued)

Random sequence genera- Low risk Statistician-generated randomisation stratified by self-reported ethnicity tion (selection bias)

\begin{tabular}{lll}
\hline $\begin{array}{l}\text { Allocation concealment } \\
\text { (selection bias) }\end{array}$ & Unclear risk & Concealment unclear \\
\hline $\begin{array}{l}\text { Blinding of participants } \\
\begin{array}{l}\text { and personnel (perfor- } \\
\text { mance bias) }\end{array}\end{array}$ & Low risk & $\begin{array}{l}\text { Blinding could not be performed because of nature of intervention, but control } \\
\text { was "time and attention-controlled", so no difference in face-to-face contact } \\
\text { between groups. Low risk of performance bias }\end{array}$ \\
\hline
\end{tabular}

Blinding of outcome as-
sessment (detection bias) $\quad$ Low risk $\quad$ Results biochemically verified

sessment (detection bias)

All outcomes

Incomplete outcome data Low risk High retention rates, similar across groups
(attrition bias)

All outcomes

\begin{tabular}{ll}
\hline Lifrak 1997 & \\
\hline Methods & $\begin{array}{l}\text { Setting: substance abuse outpatient facility, USA } \\
\text { Recruitment: community volunteers }\end{array}$ \\
\hline Participants & 69 smokers ( $\geq 1$ pack/day); $62 \%$ female, average age 39, average cigs/day 25 \\
\hline Interventions & $\begin{array}{l}\text { All received nicotine patch ( } 24 \text { hours, } 10 \text { weeks tapered dose) } \\
\text { 1. Moderate intensity: } 4 \text { meetings with nurse practitioner who reviewed self-help materials and in- } \\
\text { structed in patch use } \\
\text { 2. High intensity: as } 1 \text { plus } 16 \text { weekly } 45 \text {-minute cognitive-behavioural relapse prevention therapy from } \\
\text { clinical social worker or psychiatrist }\end{array}$
\end{tabular}

\begin{tabular}{ll}
\hline Outcomes & $\begin{array}{l}\text { Abstinence at } 12 \text { months (1-week point prevalence) } \\
\text { Validation: urine cotinine for some participants, but no corrections made for misreporting }\end{array}$ \\
\hline Notes & High-intensity participants attended median of $81 / 4$ sessions
\end{tabular}

\section{Risk of bias}

\begin{tabular}{lll}
\hline Bias & Authors' judgement & Support for judgement \\
\hline $\begin{array}{l}\text { Random sequence genera- } \\
\text { tion (selection bias) }\end{array}$ & Unclear risk & Randomisation method not described \\
\hline $\begin{array}{l}\text { Allocation concealment } \\
\text { (selection bias) }\end{array}$ & Unclear risk & No details given \\
\hline $\begin{array}{l}\text { Blinding of participants } \\
\text { and personnel (perfor- } \\
\text { mance bias) }\end{array}$ & Unclear risk & No information provided \\
$\begin{array}{l}\text { All outcomes } \\
\begin{array}{l}\text { Blinding of outcome as- } \\
\text { sessment (detection bias) } \\
\text { All outcomes }\end{array}\end{array}$ & High risk & $\begin{array}{l}\text { Incomplete urinary cotinine samples collected, so not used to validate absti- } \\
\text { nence. Intervention group received significantly more intensive face-to-face } \\
\text { contact, differential misreport possible }\end{array}$ \\
\hline
\end{tabular}


Lifrak 1997 (Continued)

Incomplete outcome data Low risk 12 administrative dropouts/exclusions not included, treatment group not (attrition bias) specified

Lowe 1997

\begin{tabular}{ll}
\hline Methods & Setting: prenatal clinic, USA \\
& Recruitment: volunteer recent quitters \\
\hline Participants & $\begin{array}{l}78 \text { pregnant women who had quit within previous } 3 \text { months (9 exclusions and } 19 \text { lost to follow-up not } \\
\text { included) } \\
\text { Age/smoking history not described } \\
\text { Therapists: health educator. Reinforcement provided by doctors and nurse trained at workshops }\end{array}$
\end{tabular}

\begin{tabular}{ll}
\hline Interventions & $\begin{array}{l}\text { 1. } 10 \text { minutes counselling with health educator. Relapse prevention materials at 5th grade reading lev- } \\
\text { el, enhanced social support with materials, chosen 'buddy'. Reinforcement at routine visits by clinic } \\
\text { staff }\end{array}$ \\
2. Usual care, including nurse advice
\end{tabular}

$\begin{array}{ll}\text { Outcomes } & \text { Continued abstinence at end of pregnancy (exact period not specified) } \\ \text { Validation: saliva thiocyanate }\end{array}$

Notes

\section{Risk of bias}

\begin{tabular}{|c|c|c|}
\hline Bias & Authors' judgement & Support for judgement \\
\hline $\begin{array}{l}\text { Random sequence genera- } \\
\text { tion (selection bias) }\end{array}$ & Unclear risk & Randomisation method not described \\
\hline $\begin{array}{l}\text { Allocation concealment } \\
\text { (selection bias) }\end{array}$ & Unclear risk & No details given \\
\hline $\begin{array}{l}\text { Blinding of participants } \\
\text { and personnel (perfor- } \\
\text { mance bias) } \\
\text { All outcomes }\end{array}$ & Low risk & $\begin{array}{l}\text { Blinding not relevant because of nature of the intervention (all relevant per- } \\
\text { sonnel involved in delivering intervention); any potential causes of perfor- } \\
\text { mance bias could be considered deliberate elements of the intervention }\end{array}$ \\
\hline $\begin{array}{l}\text { Blinding of outcome as- } \\
\text { sessment (detection bias) } \\
\text { All outcomes }\end{array}$ & Unclear risk & Biochemical validation used \\
\hline $\begin{array}{l}\text { Incomplete outcome data } \\
\text { (attrition bias) } \\
\text { All outcomes }\end{array}$ & Low risk & $\begin{array}{l}\text { Greater loss to follow-up in control, so losses to follow-up not included in de- } \\
\text { nominators to give conservative relapse prevention }\end{array}$ \\
\hline Other bias & Unclear risk & $\begin{array}{l}\text { Potential contamination, "the issue of contamination, while monitored, is one } \\
\text { that remains a concern" }\end{array}$ \\
\hline
\end{tabular}

Mayer 2010

Methods Setting: workplaces, Belgium


Mayer 2010 (Continued)

Recruitment: participants achieving abstinence in workplace-based smoking cessation programme, randomly assigned by workplace

\section{Participants}

275 adult attendees of workplace-based cessation programme who achieved 4 weeks continuous abstinence at 3 months after quit date (42 companies)

$74 \%$ male, average age 40.6 , more than $50 \%$ smoked 12 to 25 cpd, average FTND 6.5
Smokers wishing to quit invited to join cessation program through companies (13 group sessions, nicotine patches provided). Then randomly assigned to relapse prevention interventions:

1. Workplace Group Counselling (WGC), conducted at work (company decided if during or after work hours), 90 min each. Groups of 5 to 10 participants

\section{Proactive Phone Counselling (PPC), each session minimum of 10 mins}

Both programmes: 10 sessions ( 2 in month 1, monthly thereafter); participants had to pay 50 euros to participate (some companies decided to cover fees); content focused on participants' difficulties and provided psychological support, where relevant

\section{Outcomes}

4 weeks continuous abstinence at 12 months post-quit date (immediately after end of relapse prevention intervention)

Validation: $\mathrm{CO}<10 \mathrm{ppm}$, urinary cotinine $\leq 317 \mathrm{ng} / \mathrm{mL}$
New for 2013 update

Higher participation rate in PPC arm ( $81 \%$ to $95 \%)$ vs WGC arm (49\% to $70 \%)$. Not included in any metaanalyses: $87 / 141$ quit WGC, 77/134 PPC

\section{Risk of bias}

\begin{tabular}{lll}
\hline Bias & Authors' judgement & Support for judgement \\
\hline $\begin{array}{l}\text { Random sequence genera- } \\
\text { tion (selection bias) }\end{array}$ & Low risk & $\begin{array}{l}\text { Cluster-randomised by worksite. "Workplace randomization was based on us- } \\
\text { ing a single sequence of random assignments produced by a computer pro- } \\
\text { gram" }\end{array}$ \\
\hline $\begin{array}{l}\text { Allocation concealment } \\
\text { (selection bias) }\end{array}$ & Unclear risk & $\begin{array}{l}\text { Companies randomly assigned at end of cessation program, allocation con- } \\
\text { cealment not described }\end{array}$ \\
\hline $\begin{array}{l}\text { Blinding of participants } \\
\text { and personnel (perfor- } \\
\text { mance bias) } \\
\text { All outcomes }\end{array}$ & Unclear risk & Not specified \\
\hline
\end{tabular}

\begin{tabular}{lll}
\hline $\begin{array}{l}\text { Blinding of outcome as- } \\
\text { sessment (detection bias) } \\
\text { All outcomes }\end{array}$ & Low risk & Biochemically validated abstinence \\
\hline $\begin{array}{l}\text { Incomplete outcome data } \\
\text { (attrition bias) } \\
\text { All outcomes }\end{array}$ & Low risk & 5 participants lost to follow-up and counted as smokers \\
\hline Other bias & High risk & $\begin{array}{l}\text { Higher rates of abstinence detected in those with biochemically validated ab- } \\
\text { stinence at enrolment }(\leq 317 \mathrm{ng} / \mathrm{mL}) \text {. WGC arm had significantly more of these } \\
\text { participants than PPC arm }(96.4 \% \mathrm{vs} 89.4 \%) \text {. Adjusted figures not provided }\end{array}$ \\
\hline
\end{tabular}


McBride 1999

\begin{tabular}{|c|c|}
\hline Methods & $\begin{array}{l}\text { Setting: two managed care organisations, USA } \\
\text { Recruitment: pregnant smokers and recent quitters }\end{array}$ \\
\hline Participants & $\begin{array}{l}897 \text { pregnant women (excluded miscarriages), } 44 \% \text { already quit, no minimum consumption } \\
\text { Average age } 28 \text {, average cigs/day: } 15 \text { before pregnancy, } 5 \text { if still smoking }\end{array}$ \\
\hline Interventions & $\begin{array}{l}\text { 1. Prepartum intervention: letter tailored to baseline stage of change, health concerns and motivation, } \\
\text { self-help book. After } 28 \text { weeks follow-up, sent relapse prevention kit } \\
\text { 2. Telephone counselling calls, approximately } 2 \text { weeks after self-help mailing, and } 1 \text { month and } 2 \\
\text { months later. Motivational interviewing approach. Average } 81 \frac{1}{2} \text { min } \\
\text { 3. Pre/postpartum intervention: as } 1 \text {, plus } 3 \text { calls within first } 4 \text { months postpartum, av } 7.7 \text { min, } 3 \\
\text { newsletters } \\
\text { 4. Control: self-help booklet only }\end{array}$ \\
\hline
\end{tabular}

\begin{tabular}{ll} 
Outcomes & Abstinence at week 28 of pregnancy (analysis 1.1 ) and 12 months postpartum (7-day PP) (analysis 2.1). \\
& $\begin{array}{l}\text { Also assessed at } 8 \text { weeks, } 6 \text { months postpartum } \\
\text { Validation: saliva cotinine requested by mail, }<20 \mathrm{ng} / \mathrm{mL} \text {. Only self-reported rates, no difference in } \\
\text { confirmation rates }\end{array}$ \\
\hline Notes & $\begin{array}{l}\text { Abstinence at week } 28 \text { reported separately for baseline quitters } \\
\text { Relapse rate in } 28 \text { weeks quitters also reported. } 1 \text { versus } 2 \text { in analysis } 1.2 .1 \text { and } 1 \text { versus } 3 \text { in analysis } \\
1.2 .2, \text { control group split to avoid double counting in pooled total. No significant benefit of postpartum } \\
\text { intervention }\end{array}$ \\
\hline
\end{tabular}

\section{Risk of bias}

\begin{tabular}{|c|c|c|}
\hline Bias & Authors' judgement & Support for judgement \\
\hline $\begin{array}{l}\text { Random sequence genera- } \\
\text { tion (selection bias) }\end{array}$ & Unclear risk & Randomisation method not described \\
\hline $\begin{array}{l}\text { Allocation concealment } \\
\text { (selection bias) }\end{array}$ & Unclear risk & No details given \\
\hline $\begin{array}{l}\text { Blinding of participants } \\
\text { and personnel (perfor- } \\
\text { mance bias) } \\
\text { All outcomes }\end{array}$ & Low risk & $\begin{array}{l}\text { "The intervention was delivered via mail and telephone without involvement } \\
\text { of prenatal health care providers". "Counsellors were not involved in any fol- } \\
\text { low-up survey activities" }\end{array}$ \\
\hline $\begin{array}{l}\text { Blinding of outcome as- } \\
\text { sessment (detection bias) } \\
\text { All outcomes }\end{array}$ & Low risk & $\begin{array}{l}\text { Biochemical validation used, not reported: "Since there were no be- } \\
\text { tween-group differences in the proportion of saliva samples returned or the } \\
\text { proportion confirmed, the primary trial outcomes were based on self-reported } \\
\text { smoking status" }\end{array}$ \\
\hline
\end{tabular}

Incomplete outcome data Low risk Nonresponders assumed to have relapsed
(attrition bias)

All outcomes

\section{McBride 2004}

\begin{tabular}{ll}
\hline Methods & Setting: Army Medical Center, USA \\
& Recruitment: pregnant smokers and recent quitters with partners \\
\hline Participants & $\begin{array}{l}316 \text { pregnant recent quitters, } 267 \text { continuing smokers (excluded miscarriages); average age 24, average } \\
\text { cigs/day prepregnancy } 13\end{array}$ \\
\hline
\end{tabular}


McBride 2004 (Continued)

Interventions
Both interventions included prepartum and postpartum components, in addition to usual care 1. Women only (WO); 3 counselling calls in pregnancy, 3 postpartum, monthly. Motivational interviewing. Late pregnancy relapse prevention kit

2. Partner-assisted (PA); as WO, plus advice on using partner as coach, and 6 calls to partner. Cessation support for smoking partners

3. Usual care; provider advice and mailed pregnancy-specific self-help

\begin{tabular}{ll} 
Outcomes & $\begin{array}{l}\text { Abstinence at week } 28 \text { of pregnancy and } 12 \text { months postpartum (7-day PP). Also assessed at } 8 \text { weeks, } 6 \\
\text { months postpartum } \\
\text { Validation: saliva cotinine requested by mail, no difference in return rates, disconfirmation rates not } \\
\text { given, only self-reported rates reported }\end{array}$ \\
\hline Notes & New for 2009 update \\
& End of pregnancy abstinence amongst baseline quitters, combining interventions 1 and 2 versus con- \\
trol in analysis 1.1 . No significant effect of either intervention on end of pregnancy abstinence amongst \\
baseline smokers. 12 months postpartum abstinence for those quit at end of pregnancy in analysis 1.2. \\
Abstinence rates not given separately for those quit at randomisation, but $2 / 3$ of end-of-pregnancy quit- \\
ters came from this category, and the prepartum interventions did not increase cessation
\end{tabular}

\section{Risk of bias}

\begin{tabular}{lll}
\hline Bias & Authors' judgement & Support for judgement \\
\hline $\begin{array}{l}\text { Random sequence genera- } \\
\text { tion (selection bias) }\end{array}$ & Unclear risk & Randomisation method not stated \\
\hline $\begin{array}{l}\text { Allocation concealment } \\
\text { (selection bias) }\end{array}$ & Unclear risk & No details given \\
\hline $\begin{array}{l}\text { Blinding of participants } \\
\text { and personnel (perfor- } \\
\text { mance bias) }\end{array}$ & Unclear risk & No blinding reported \\
All outcomes & \\
\hline $\begin{array}{l}\text { Blinding of outcome as- } \\
\text { sessment (detection bias) } \\
\text { All outcomes }\end{array}$ & Unclear risk & $\begin{array}{l}\text { Biochemical validation conducted but not used in outcome data. "Saliva re- } \\
\text { turn rates did not differ by condition at either follow-up", but rates of return } \\
\text { low and level of misreport not specified }\end{array}$ \\
\hline $\begin{array}{l}\text { Incomplete outcome data } \\
\text { (attrition bias) } \\
\begin{array}{l}\text { All outcomes } \\
\hline\end{array}\end{array}$ & Unclear risk & Excluded miscarriages, no other information on losses \\
\hline
\end{tabular}

\section{McDaniel 2015}

Methods Setting: Quit for Life employers/health plans, USA

Recruitment: users enrolled from employer and health Quit for Life programmes

Participants $\begin{aligned} & 1785 \text { smokers who were abstinent for at least } 24 \text { hours, } 591 \text { TEQ-20, } 602 \text { TEQ-10 and } 592 \text { control } \\ & 45.8 \% \text { male, average age 43, average cigs/day } 17\end{aligned}$

Interventions

TEQ-20: Technology Enhanced Quitline-20: 20 Interactive Voice Response - delivered relapse risk assessments which triggered a transfer to a Quit Coach for participants exceeding thresholds

TEQ-10: Technology Enhanced Quitline-10: 10 Interactive Voice Response - delivered relapse risk assessments which triggered a transfer to a Quit Coach for participants exceeding thresholds 
McDaniel 2015 (Continued)

Control: Standard treatment

\begin{tabular}{ll}
\hline Outcomes & $\begin{array}{l}\text { 30-day point prevalence at } 12 \text { months } \\
\text { Validation: self-report only }\end{array}$ \\
\hline Notes & $\begin{array}{l}\text { Funding: "The study was funded by the National Institutes for Health (National Cancer Institute grant } \\
\text { number R01 CA138936-03) from the United States Department of Health and Human Services." } \\
\text { Declaration of interests: "KAV, BHC, and SMZ declare employment at Alere Wellbeing, the provider of } \\
\text { quitline services in this study." }\end{array}$ \\
\hline
\end{tabular}

\section{Risk of bias}

\begin{tabular}{lll}
\hline Bias & Authors' judgement & Support for judgement \\
\hline $\begin{array}{l}\text { Random sequence genera- } \\
\text { tion (selection bias) }\end{array}$ & Low risk & Computer-randomisation performed \\
\hline $\begin{array}{l}\text { Allocation concealment } \\
\text { (selection bias) }\end{array}$ & Low risk & Allocation concealed by computer system \\
\hline $\begin{array}{l}\text { Blinding of participants } \\
\text { and personnel (perfor- } \\
\text { mance bias) }\end{array}$ & Unclear risk & Blinding unclear \\
All outcomes & \\
\hline $\begin{array}{l}\text { Blinding of outcome as- } \\
\text { sessment (detection bias) } \\
\text { All outcomes }\end{array}$ & High risk & Results not biochemically verified \\
\hline $\begin{array}{l}\text { Incomplete outcome data } \\
\text { (attrition bias) } \\
\begin{array}{l}\text { All outcomes } \\
\hline\end{array}\end{array}$ & Low risk & No significant differences in response rates by intervention group \\
\hline
\end{tabular}

\section{McNaughton 2013}

$\begin{array}{ll}\text { Methods } & \text { Setting: outpatient clinic, Canada } \\ \text { Recruitment: newspaper advertisements }\end{array}$

Participants 44 smokers who had quit following a course of varenicline, 23 intervention and 21 control

$66.6 \%$ male, average age 54, average cigs/day 17

Interventions

Pre-randomisation, both groups received 12 weeks varenicline + Interactive Voice Response calls

Relapse prevention: Interactive Voice Response calls every 2 weeks from weeks 13 to 52

Control: No further treatment

\begin{tabular}{ll}
\hline Outcomes & Prolonged abstinence at 2 years \\
& Validation: $\mathrm{CO}<10 \mathrm{ppm}$ \\
\hline Notes & Funding: "This study was funded by Pfizer Canada, producers of varenicline"
\end{tabular}


McNaughton 2013 (Continued)

Declaration of interests: "Jiri Frohlich was a member of Pfizer (Canada) Medical Advisory Board and received speaking honoraria. He also participated in several clinical trials and received grants for investigator initiated studies."

\section{Risk of bias}

\begin{tabular}{lll}
\hline Bias & Authors' judgement & Support for judgement \\
\hline $\begin{array}{l}\text { Random sequence genera- } \\
\text { tion (selection bias) }\end{array}$ & Low risk & Randomisation stratified by motivation and addiction levels \\
\hline $\begin{array}{l}\text { Allocation concealment } \\
\text { (selection bias) }\end{array}$ & Unclear risk & Concealment not reported \\
\hline $\begin{array}{l}\text { Blinding of participants } \\
\text { and personnel (perfor- } \\
\text { mance bias) }\end{array}$ & Unclear risk & Blinding not reported \\
All outcomes & \\
\hline
\end{tabular}

Blinding of outcome as- Low risk Results biochemically verified

sessment (detection bias)

All outcomes

Incomplete outcome data Low risk Low attrition rates at 2 years

(attrition bias)

All outcomes

Mermelstein 2003

\begin{tabular}{ll}
\hline Methods & Setting: cessation clinic, USA \\
& Recruitment: community volunteers for cessation programme \\
\hline Participants & 341 quitters at the end of a 7-week group cessation programme (non-abstinent subgroup not relevant \\
& to this review) \\
& Demographics for all $771: 66 \%$ female, average age 43, average cigs/day 23
\end{tabular}

Interventions
weekly then 3 to 6 alternate weeks, 15 min each
2. Supportive but nonspecific proactive counselling calls from counsellor, same schedule

\begin{tabular}{ll}
\hline Outcomes & Abstinence at 15 months, 7-day point prevalence \\
& Validation: none \\
\hline Notes & $\begin{array}{l}\text { Analysis } 4.1 \text { but borderline to pool with other studies because both groups could constitute relapse } \\
\text { prevention; primarily a test of content. Exclusion did not change finding }\end{array}$ \\
\hline
\end{tabular}

\section{Risk of bias}

\begin{tabular}{lll}
\hline Bias & Authors' judgement & Support for judgement \\
\hline $\begin{array}{l}\text { Random sequence genera- } \\
\text { tion (selection bias) }\end{array}$ & Unclear risk & Cluster-randomised by cessation group \\
\hline $\begin{array}{l}\text { Allocation concealment } \\
\text { (selection bias) }\end{array}$ & Unclear risk & Not specified \\
\hline
\end{tabular}


Mermelstein 2003 (Continued)

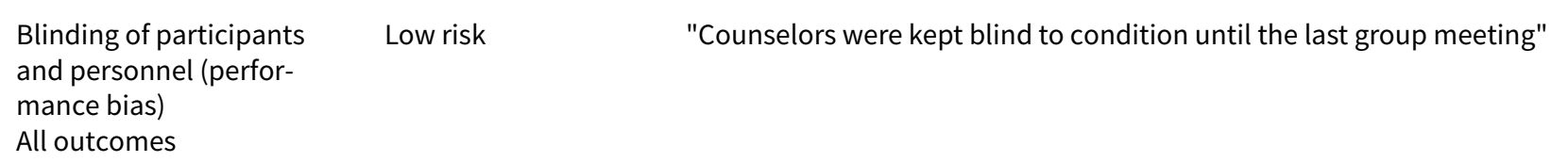

Blinding of participants L Low risk $\quad$ "Counselors were kept blind to condition until the last group meeting"

Blinding of outcome as- Low risk sessment (detection bias)

All outcomes

Incomplete outcome data Low risk
(attrition bias)

Biochemical validation not used, but same intensity of contact in both groups, differential misreport unlikely

(attrition bias)

All outcomes

\section{Morasco 2006}

\begin{tabular}{ll}
\hline Methods & $\begin{array}{l}\text { Setting: prenatal clinic, USA } \\
\text { Recruitment: recent quitters }\end{array}$ \\
\hline Participants & 33 pregnant recent quitters (7 days) (subgroup of trial); average age 22, average cigs/day before quit 13 \\
\hline Interventions & $\begin{array}{l}\text { All participants received prompted provider advice and self-help } \\
\text { 1. Individual counselling; 90-min psychotherapy session and bimonthly phone calls from mental } \\
\text { health counsellors } \\
\text { 2. Usual care }\end{array}$
\end{tabular}

\begin{tabular}{ll}
\hline Outcomes & Abstinence at end of pregnancy and 6 months postpartum (7-d PP) \\
Validation: $\mathrm{CO} \leq 8 \mathrm{ppm}$
\end{tabular}

\begin{tabular}{|c|c|c|}
\hline Notes & \multicolumn{2}{|c|}{ New for 2009 update. Baseline smoker results reported separately, not used in this review } \\
\hline \multicolumn{3}{|l|}{ Risk of bias } \\
\hline Bias & Authors' judgement & Support for judgement \\
\hline $\begin{array}{l}\text { Random sequence genera- } \\
\text { tion (selection bias) }\end{array}$ & Unclear risk & Randomisation method not described \\
\hline $\begin{array}{l}\text { Allocation concealment } \\
\text { (selection bias) }\end{array}$ & Unclear risk & No details given \\
\hline $\begin{array}{l}\text { Blinding of participants } \\
\text { and personnel (perfor- } \\
\text { mance bias) } \\
\text { All outcomes }\end{array}$ & Unclear risk & No details given \\
\hline $\begin{array}{l}\text { Blinding of outcome as- } \\
\text { sessment (detection bias) } \\
\text { All outcomes }\end{array}$ & Low risk & Biochemical validation used \\
\hline $\begin{array}{l}\text { Incomplete outcome data } \\
\text { (attrition bias) } \\
\text { All outcomes }\end{array}$ & Unclear risk & $\begin{array}{l}\text { Participants lost to follow-up counted as smokers, but numbers lost to fol- } \\
\text { low-up not broken down by group }\end{array}$ \\
\hline
\end{tabular}


Niaura 1999

\begin{tabular}{ll}
\hline Methods & $\begin{array}{l}\text { Setting: cessation clinic, USA } \\
\text { Recruitment: community volunteers }\end{array}$ \\
\hline Participants & 120 smokers; $50 \%$ female, average age 44, average cigs/day 28 \\
\hline Interventions & $\begin{array}{l}\text { All participants received single brief individual counselling session } 1 \text { week before TQD and instructed to } \\
\text { use ALA self-help manual 'Freedom from smoking for you and your family', CO measured. All interven- } \\
\text { tions used } 5 \text { sessions over } 2 \text { weeks post TQD, led by PhD level therapists } \\
\text { 1. Cognitive-behavioural with cue exposure (75-min sessions) imagined high-risk settings } \\
\text { 2. Cognitive-behavioural with cue exposure and nicotine gum (90 min) } \\
\text { 3. Brief cognitive-behavioural. Reviewed progress and reinforced use of self-help manual. (15-min ses- } \\
\text { sions). Control for } 1 \\
\text { 4. Cognitive-behavioural and nicotine gum (60 min). Control for } 2\end{array}$
\end{tabular}

\begin{tabular}{ll}
\hline Outcomes & $\begin{array}{l}\text { Sustained abstinence, } 12 \text { months and all previous follow-ups (1, 3, } 6 \text { months) } \\
\text { Validation: } \mathrm{CO}<8 \mathrm{ppm}\end{array}$ \\
\hline Notes & Test of imaginary cue exposure for relapse prevention. 1 and 2 vs 3 and 4 in Analysis 7.1
\end{tabular}

\section{Risk of bias}

\begin{tabular}{lll}
\hline Bias & Authors' judgement & Support for judgement \\
\hline $\begin{array}{l}\text { Random sequence genera- } \\
\text { tion (selection bias) }\end{array}$ & Unclear risk & Randomisation method not stated \\
\hline $\begin{array}{l}\text { Allocation concealment } \\
\text { (selection bias) }\end{array}$ & Unclear risk & No details given \\
\hline
\end{tabular}

$\begin{array}{ll}\begin{array}{l}\text { Blinding of participants } \\ \text { and personnel (perfor- }\end{array} & \text { Unclear risk } \\ \begin{array}{l}\text { mance bias) } \\ \text { All outcomes }\end{array} & \begin{array}{l}\text { "Counselors were kept blind to the relapse prevention condition to which sub- } \\ \text { jects were assigned". Participants not blinded, and no placebo }\end{array}\end{array}$

\begin{tabular}{ll}
\hline Blinding of outcome as- & Low risk
\end{tabular}

Incomplete outcome data Unclear risk
(attrition bias)
All outcomes

Pbert 2004

\begin{tabular}{ll}
\hline Methods & $\begin{array}{l}\text { Setting: five community health clinics, USA } \\
\text { Recruitment: low-income women receiving prenatal care and participating in Special Supplemental } \\
\text { Nutrition Programme }\end{array}$ \\
\hline Participants & $\begin{array}{l}168 \text { pregnant recent quitters (subgroup of trial); average age 26, average cigs/day } 15 \text { to } 18 \text { for whole } \\
\text { sample }\end{array}$ \\
\hline Interventions & $\begin{array}{l}\text { System-level intervention } \\
1 . \text { Training to implement guideline-based 4 A's approach for obstetric, paediatric and nutrition pro- } \\
\text { gramme providers in the Community Health Centres, practice management system for screening and } \\
\text { prompts, interclinic communication }\end{array}$
\end{tabular}


Pbert 2004 (Continued)

2. No training, usual care from clinic providers

\begin{tabular}{ll}
\hline Outcomes & $\begin{array}{l}\text { Abstinence at delivery (30-d PP) assessed retrospectively at 1-month postpartum assessment, } 6 \\
\text { months postpartum } \\
\text { Validation: saliva cotinine } \leq 20 \mathrm{ppm}\end{array}$ \\
\hline Notes & $\begin{array}{l}\text { New for } 2009 \text { update } \\
\text { Saliva collection was incomplete, and lesser agreement was noted between self-report and cotinine } \\
\text { values in intervention group, although difference significant only at final follow-up. Not pooled with } \\
\text { other studies. When non-responders were treated as smokers, the OR for not smoking at end of preg- } \\
\text { nancy was } 0.95(\mathrm{P}=0.95)\end{array}$ \\
\hline
\end{tabular}

\section{Risk of bias}

\begin{tabular}{|c|c|c|}
\hline Bias & Authors' judgement & Support for judgement \\
\hline $\begin{array}{l}\text { Random sequence genera- } \\
\text { tion (selection bias) }\end{array}$ & Unclear risk & Cluster-randomised by clinic, method not stated \\
\hline $\begin{array}{l}\text { Allocation concealment } \\
\text { (selection bias) }\end{array}$ & High risk & $\begin{array}{l}\text { Clinics recruited participants after randomisation, } 1 \text { control clinic dropped out } \\
\text { because of poor recruitment, } 2 \text { clinics enrolled }>50 \% \text { of participants }\end{array}$ \\
\hline $\begin{array}{l}\text { Blinding of participants } \\
\text { and personnel (perfor- } \\
\text { mance bias) } \\
\text { All outcomes }\end{array}$ & Unclear risk & Not specified \\
\hline $\begin{array}{l}\text { Blinding of outcome as- } \\
\text { sessment (detection bias) } \\
\text { All outcomes }\end{array}$ & Low risk & Biochemical validation used \\
\hline $\begin{array}{l}\text { Incomplete outcome data } \\
\text { (attrition bias) } \\
\text { All outcomes }\end{array}$ & Low risk & $\begin{array}{l}\text { Higher loss to follow-up in intervention }(46 / 81,57 \%) \text { than control }(37 / 77,48 \%) \text {. } \\
\text { ITT analysis reported }\end{array}$ \\
\hline
\end{tabular}

\section{Pollak 2016}

\begin{tabular}{ll}
\hline Methods & Setting: prenatal clinics, USA \\
& Recruitment: contacted at prenatal clinics \\
\hline Participants & 382 ex-smokers ( 1 month abstinent), 188 intervention and 194 control \\
& Pregnant women, average age 25, average cigs/day not reported \\
\hline Interventions & $\begin{array}{l}\text { Relapse prevention: Stepped-care based on bio-behavioural risk profile + received one 'Forever Free for } \\
\text { Baby and Me' booklet in last trimester of pregnancy } \\
\text { - 'low-risk' offered one in-person session, one phone call in third trimester and } 7 \text { calls postpartum until } \\
9 \text { months postpartum } \\
\text { postpartum until } 9 \text { months postpartum } \\
\text { Control: Received one 'Forever Free for Baby and Me' booklet in last trimester of pregnancy, then } \\
\text { mailed } 11 \text { monthly newsletters }\end{array}$ \\
\hline
\end{tabular}


Pollak 2016 (Continued)

Validation: $\mathrm{CO}<10 \mathrm{ppm}$ and cotinine $<0.5 \mathrm{mg} / \mathrm{dL}$

Notes
Funding: "This work was supported by the National Institutes of Health (R01NR009429). The opinions and assentation's [sic] contained herein are the private views of the authors and are not to be construed as official or reflecting the views of the Department of the Army or the Department of Defense."

Declaration of interests: None declared

\section{Risk of bias}

\begin{tabular}{lll}
\hline Bias & Authors' judgement & Support for judgement \\
\hline $\begin{array}{l}\text { Random sequence genera- } \\
\text { tion (selection bias) }\end{array}$ & Low risk & Computerised randomisation performed \\
\hline $\begin{array}{l}\text { Allocation concealment } \\
\text { (selection bias) }\end{array}$ & Unclear risk & Concealment not described \\
\hline $\begin{array}{l}\text { Blinding of participants } \\
\text { and personnel (perfor- } \\
\text { mance bias) }\end{array}$ & Unclear risk & Blinding not described \\
All outcomes & \\
\hline $\begin{array}{l}\text { Blinding of outcome as- } \\
\text { sessment (detection bias) } \\
\text { All outcomes }\end{array}$ & Low risk & Results biochemically verified \\
\hline $\begin{array}{l}\text { Incomplete outcome data } \\
\text { (attrition bias) } \\
\text { All outcomes }\end{array}$ & Unclear risk & Unclear from reported results \\
\hline
\end{tabular}

Powell 1981

\begin{tabular}{|c|c|}
\hline Methods & $\begin{array}{l}\text { Setting: clinic, USA } \\
\text { Recruitment: community volunteers } \\
\text { Therapist: senior author }\end{array}$ \\
\hline Participants & 51 quitters ( 2 treatment dropouts excluded); 57\% female, average age 36, average cigs/day 29 \\
\hline Interventions & $\begin{array}{l}\text { All participants received the same cessation programme in a single group. Introductory meeting and } 4 \\
\text { consecutive treatment meetings a week later, } 1 \frac{1 / 2}{2} \text { hours. Systematic focus on skill development. Also } \\
\text { used a novel aversive smoking exercise conducted at each session } \\
\text { Maintenance/relapse prevention conditions: } \\
\text { 1. } 4 \text {-week support group (number of meetings not specified) } \\
\text { 2. Telephone contact system allowing participants to phone each other } \\
\text { 3. No contact control }\end{array}$ \\
\hline
\end{tabular}

\begin{tabular}{ll}
\hline Outcomes & $\begin{array}{l}\text { Abstinence at } 1 \text { year, not defined } \\
\text { Validation: none }\end{array}$
\end{tabular}

Validation: none

Notes Arm 2 not shown in graphs, all arms had similar quit rates

\section{Risk of bias}

Bias Authors' judgement Support for judgement


Powell 1981 (Continued)

$\begin{array}{ll}\begin{array}{l}\text { Random sequence genera- } \\ \text { tion (selection bias) }\end{array} & \text { Unclear risk } \\ \end{array}$
tion (selection bias)

families and friends

Allocation concealment $\quad$ Unclear risk $\quad$ No details given
(selection bias)

Blinding of participants Low risk

and personnel (perfor-

Subjects randomly assigned to maintenance condition "at the end of the treat-

mance bias)

All outcomes

\begin{tabular}{|c|c|c|}
\hline $\begin{array}{l}\text { Blinding of outcome as- } \\
\text { sessment (detection bias) }\end{array}$ & High risk & $\begin{array}{l}\text { No biochemical validation used, intensity of contact different between condi- } \\
\text { tions with some in person, differential self-report possible }\end{array}$ \\
\hline
\end{tabular}

All outcomes

Incomplete outcome data Low risk $\quad$ All but one participant contacted at follow-up
(attrition bias)

All outcomes

\begin{tabular}{|c|c|c|}
\hline Methods & \multicolumn{2}{|c|}{$\begin{array}{l}\text { Setting: obstetric wards in } 5 \text { hospitals, Canada } \\
\text { Recruitment: postpartum women }\end{array}$} \\
\hline Participants & \multicolumn{2}{|c|}{$\begin{array}{l}251 \text { women who had given up smoking for at least } 6 \text { weeks before delivery; average age } 28 \text {, average } \\
\text { cigs/day } 10,74 \% \text { first child }\end{array}$} \\
\hline Interventions & \multicolumn{2}{|c|}{$\begin{array}{l}\text { 1. Counselling session in hospital }+8 \text { telephone (weekly for } 1 \text { month, biweekly for } 2 \text { months). Skills } \\
\text { training. Self-help pamphlets, no-smoking materials. Therapists: trained nurse counsellors } \\
\text { 2. Usual care }\end{array}$} \\
\hline Outcomes & \multicolumn{2}{|c|}{$\begin{array}{l}\text { Continuous abstinence } 12 \text { months postdelivery } \\
\text { Validation: } \mathrm{CO}<10 \mathrm{ppm} \text { for participants interviewed in person. Data collectors blind }\end{array}$} \\
\hline \multicolumn{3}{|l|}{ Notes } \\
\hline \multicolumn{3}{|l|}{ Risk of bias } \\
\hline Bias & Authors' judgement & Support for judgement \\
\hline $\begin{array}{l}\text { Random sequence genera- } \\
\text { tion (selection bias) }\end{array}$ & Low risk & $\begin{array}{l}\text { "Identification numbers randomly assigned to } 2 \text { groups, in blocks of } 50 \text {, via a } \\
\text { computer software package" }\end{array}$ \\
\hline $\begin{array}{l}\text { Allocation concealment } \\
\text { (selection bias) }\end{array}$ & Unclear risk & No details about sequence concealment \\
\hline $\begin{array}{l}\text { Blinding of participants } \\
\text { and personnel (perfor- } \\
\text { mance bias) } \\
\text { All outcomes }\end{array}$ & Unclear risk & $\begin{array}{l}\text { Research assistants responsible for outcome assessment were blinded, further } \\
\text { details not reported }\end{array}$ \\
\hline $\begin{array}{l}\text { Blinding of outcome as- } \\
\text { sessment (detection bias) } \\
\text { All outcomes }\end{array}$ & Low risk & Biochemical validation used at in-person follow-ups ( $89 \%$ of participants) \\
\hline
\end{tabular}


Ratner 2000 (Continued)

Incomplete outcome data Low risk Denominator excludes 13 not reached at follow-up. No differential dropout (attrition bias)

All outcomes

\section{Razavi 1999}

\begin{tabular}{ll}
\hline Methods & $\begin{array}{l}\text { Setting: workplaces, Belgium } \\
\text { Recruitment: employee volunteers }\end{array}$ \\
\hline Participants & $\begin{array}{l}993 \text { began cessation programme, } 349 \text { abstinent at } 3 \text { months, } 344 \text { entered relapse prevention phase. } \\
38 \% \text { female, average age } 39\end{array}$ \\
\hline Interventions & $\begin{array}{l}\text { Initial cessation programme of } 7 \text { fortnightly visits. Nicotine patch provided if FTQ score } \geq 5 . \text { Only quit- } \\
\text { ters abstinent for } 1 \text { month enrolled in relapse prevention } \\
\text { 1. } 10 \text { monthly sessions, including group discussion and role-play led by professional counsellor } \\
\text { 2. } 10 \text { sessions of group discussion led by former smokers } \\
\text { 3. No relapse prevention }\end{array}$ \\
\hline Outcomes & $\begin{array}{l}\text { Abstinence for } 9 \text { months from start of relapse prevention programme } \\
\text { (Rates for CO and self-report alone also reported; higher than for doubly validated rates) }\end{array}$ \\
\hline Notes & $\begin{array}{l}\text { Interventions } 1 \text { and } 2 \text { combined in Analysis } 4.1 . \text { Separate quit rates: Intervention } 1.59 / 135 \text { (44\%); Inter- } \\
\text { vention } 2.33 / 88 \text { ( } 37.5 \%) \text {, difference not statistically significant }\end{array}$
\end{tabular}

\section{Risk of bias}

\begin{tabular}{|c|c|c|}
\hline Bias & Authors' judgement & Support for judgement \\
\hline $\begin{array}{l}\text { Random sequence genera- } \\
\text { tion (selection bias) }\end{array}$ & Low risk & Cluster-randomised by company, using random number and blinded list \\
\hline $\begin{array}{l}\text { Allocation concealment } \\
\text { (selection bias) }\end{array}$ & Low risk & Company allocation blinded and participants recruited before randomisation \\
\hline $\begin{array}{l}\text { Blinding of participants } \\
\text { and personnel (perfor- } \\
\text { mance bias) } \\
\text { All outcomes }\end{array}$ & Low risk & $\begin{array}{l}\text { No blinding reported but randomisation once achieved cessation and cluster } \\
\text { randomisation by worksite, performance bias unlikely }\end{array}$ \\
\hline $\begin{array}{l}\text { Blinding of outcome as- } \\
\text { sessment (detection bias) } \\
\text { All outcomes }\end{array}$ & Low risk & Biochemical validation used \\
\hline $\begin{array}{l}\text { Incomplete outcome data } \\
\text { (attrition bias) } \\
\text { All outcomes }\end{array}$ & Unclear risk & $\begin{array}{l}\text { Losses to follow-up not reported, all randomly assigned participants included } \\
\text { in analyses }\end{array}$ \\
\hline
\end{tabular}

Reitzel 2010

$\begin{array}{ll}\text { Methods } & \text { Setting: Texas, USA } \\ \text { Recruitment: pregnant women recruited through local health system or community advertisements }\end{array}$


Reitzel 2010 (Continued)

Participants 251 low-income women who quit smoking during pregnancy

Average age 24.6 , average cpd 10.2 pre-quit, $92.4 \%$ quit smoking approximately 8 weeks after pregnancy

All participants received self-help materials and 5 to 10 min of US guideline-based brief relapse preven-
tion advice
1. MAPS: 6 telephone-based counselling sessions at weeks 34 and 36 prepartum and at week $2,4,7$, and
16 postpartum, using combined motivational enhancement and social cognitive approach
2. MAPS+: As per 1, plus 2 additional in-person counselling sessions at baseline and at week 8 postpar-
tum
3. Control: usual care

\begin{tabular}{ll}
\hline Outcomes & Continuous abstinence at 8 and 26 weeks postpartum (defined as no smoking since delivery date) \\
& Validation: $\mathrm{CO}<10 \mathrm{ppm}$ and/or cotinine $<20 \mathrm{ng} / \mathrm{mL}$ \\
\hline Notes & New for 2013 update \\
$80 \%$ of intervention participants received at least 4 calls \\
MAPS and MAPS + combined for analysis in trial report; groups did not differ on baseline characteristics, \\
completed calls, session length, or percentage of participants abstinent. \\
Number abstinent not provided, extrapolated from percentages given in trial report
\end{tabular}

\section{Risk of bias}

Bias Authors' judgement Support for judgement

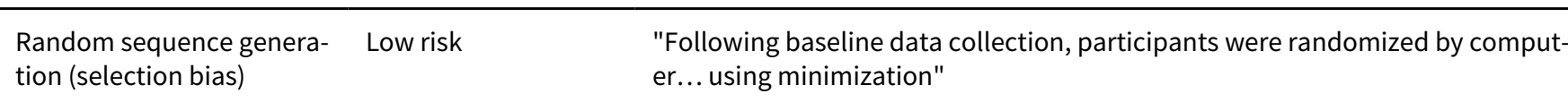

\begin{tabular}{|c|c|c|}
\hline $\begin{array}{l}\text { Allocation concealment } \\
\text { (selection bias) }\end{array}$ & Low risk & Centralised, see above \\
\hline $\begin{array}{l}\text { Blinding of participants } \\
\text { and personnel (perfor- } \\
\text { mance bias) } \\
\text { All outcomes }\end{array}$ & High risk & $\begin{array}{l}\text { No blinding: "Neither participants nor research personnel was blind to treat- } \\
\text { ment condition assignment following randomization" }\end{array}$ \\
\hline $\begin{array}{l}\text { Blinding of outcome as- } \\
\text { sessment (detection bias) } \\
\text { All outcomes }\end{array}$ & Low risk & Smoking status biochemically validated \\
\hline $\begin{array}{l}\text { Incomplete outcome data } \\
\text { (attrition bias) } \\
\text { All outcomes }\end{array}$ & Low risk & $\begin{array}{l}\text { Participants lost to follow-up counted as smokers in ITT analysis. Similar rates } \\
\text { of dropout across groups (UC 23\%; MAPS 32\%; MAPS+ 24\%) }\end{array}$ \\
\hline
\end{tabular}

\section{Ruger 2008}

\section{Methods}

Setting: obstetric clinics, USA

Recruitment: pregnant women who smoked or had quit within 3 months of baseline 
Ruger 2008 (Continued)

Participants 57 pregnant recent quitters (subgroup of trial), average age of whole sample 26

\begin{tabular}{ll}
\hline Interventions & 1. Motivational interviewing at home visits (average 3). Tailored to stage of change, self-help materials \\
2. Usual care
\end{tabular}

2. Usual care

Outcomes Quit at 6 months postpartum

Validation: salivary cotinine, but cut-off and percentage validated not specified

Notes

\section{Risk of bias}

\begin{tabular}{lll}
\hline Bias & Authors' judgement & Support for judgement \\
\hline $\begin{array}{l}\text { Random sequence genera- } \\
\text { tion (selection bias) }\end{array}$ & Unclear risk & Method not described \\
\hline $\begin{array}{l}\text { Allocation concealment } \\
\text { (selection bias) }\end{array}$ & High risk & $\begin{array}{l}\text { No details given, but higher proportion of recent quitters in control (23\%) than } \\
\text { intervention (15\%) suggested possible selection bias }\end{array}$ \\
\hline $\begin{array}{l}\text { Blinding of participants } \\
\text { and personnel (perfor- } \\
\text { mance bias) }\end{array}$ & Unclear risk & Not specified \\
$\begin{array}{l}\text { All outcomes } \\
\begin{array}{l}\text { Blinding of outcome as- } \\
\text { sessment (detection bias) } \\
\text { All outcomes }\end{array}\end{array}$ & Unclear risk & $\begin{array}{l}\text { "Smoking status was verified biochemically by collecting saliva samples for } \\
\text { saliva cotinine analysis", unclear whether validation completed, confirmation } \\
\text { rates not reported }\end{array}$ \\
\hline $\begin{array}{l}\text { Incomplete outcome data } \\
\text { (attrition bias) } \\
\text { All outcomes }\end{array}$ & Unclear risk & $\begin{array}{l}\text { Dropouts not included in reported denominators, included as smokers in } \\
\text { meta-analysis }\end{array}$ \\
\hline
\end{tabular}

Schmitz 1999

\begin{tabular}{|c|c|}
\hline Methods & $\begin{array}{l}\text { Setting: hospital, USA } \\
\text { Recruitment: women with or at risk of coronary artery disease (CAD) }\end{array}$ \\
\hline Participants & $\begin{array}{l}\text { Two separate samples recruited: } \\
\text { 1. } 53 \text { inpatients with CAD who stopped smoking during hospitalisation and wanted to stay quit } \\
\text { 2. } 107 \text { women volunteering for cessation treatment who had }>1 \text { CAD risk factor } \\
\text { Therapists: } 2 \text { smoking counsellors and } 2 \text { clinical psychology interns }\end{array}$ \\
\hline Interventions & $\begin{array}{l}\text { 1. Coping skills relapse prevention, } 6 \times 1 \text { hour, including stress management, homework } \\
\text { 2. Health Belief model, } 6 \times 1 \text { hour smoking-related health information related to disease state or CAD } \\
\text { profile. Focus on benefits of stopping }\end{array}$ \\
\hline Outcomes & $\begin{array}{l}\text { PP abstinence at } 6 \text { months } \\
\text { Validation: } \mathrm{CO}<9 \mathrm{ppm} \text {, urine cotinine }<10 \mathrm{ng} / \mathrm{mL} \\
\text { Not all quitters tested, confirmation rates not reported }\end{array}$ \\
\hline Notes & $\begin{array}{l}\text { Inpatient subgroup in quitters section, Analysis 2.1; CAD risk group in trials in smokers, matched con- } \\
\text { trol section, Analysis } 7.1 \\
\text { Quit rates were lower in the CAD sample than in the at-risk group }\end{array}$ \\
\hline
\end{tabular}


Schmitz 1999 (Continued)

Risk of bias

\begin{tabular}{|c|c|c|}
\hline Bias & Authors' judgement & Support for judgement \\
\hline $\begin{array}{l}\text { Random sequence genera- } \\
\text { tion (selection bias) }\end{array}$ & Unclear risk & Randomisation method not described \\
\hline $\begin{array}{l}\text { Allocation concealment } \\
\text { (selection bias) }\end{array}$ & Unclear risk & No details given \\
\hline $\begin{array}{l}\text { Blinding of participants } \\
\text { and personnel (perfor- } \\
\text { mance bias) } \\
\text { All outcomes }\end{array}$ & Unclear risk & Not specified \\
\hline $\begin{array}{l}\text { Blinding of outcome as- } \\
\text { sessment (detection bias) } \\
\text { All outcomes }\end{array}$ & Unclear risk & $\begin{array}{l}\text { Biochemical validation used, but not all quitters tested and confirmation rates } \\
\text { not reported }\end{array}$ \\
\hline $\begin{array}{l}\text { Incomplete outcome data } \\
\text { (attrition bias) } \\
\text { All outcomes }\end{array}$ & Low risk & $\begin{array}{l}\text { Post-randomisation dropouts who did not complete baseline and begin treat- } \\
\text { ment were not included in any data, other losses to follow-up counted as } \\
\text { smokers }\end{array}$ \\
\hline
\end{tabular}

Schroter 2006

\begin{tabular}{ll}
\hline Methods & $\begin{array}{l}\text { Setting: four workplaces, Germany } \\
\text { Recruitment: volunteer employees }\end{array}$ \\
\hline Participants & 79 smokers ( $\geq 10$ cigs/day); $42 \%$ female, average age 40 , average cigs/day 24 \\
\hline Interventions & $\begin{array}{l}\text { Both conditions provided } 6 \times 90 \text { min sessions over } 8 \text { weeks in groups of } 8 \text { to } 12 \text { led by qualified } \\
\text { providers } \\
\text { 1. relapse prevention; skills training, planning and practising coping strategies } \\
\text { 2. Standard behavioural cessation course with focus on positive changes obtained through abstinence. } \\
\text { Included self-monitoring, environmental cue control, problem-solving skills }\end{array}$
\end{tabular}

\begin{tabular}{ll}
\hline Outcomes & $\begin{array}{l}\text { Continuous abstinence at } 12 \text { months, not defined further } \\
\text { Validation: none }\end{array}$ \\
\hline
\end{tabular}

\begin{tabular}{ll}
\hline Notes & New for 2009 update \\
Compared relapse prevention with matched standard programme
\end{tabular}

\section{Risk of bias}

\begin{tabular}{lll}
\hline Bias & Authors' judgement & Support for judgement \\
\hline $\begin{array}{l}\text { Random sequence genera- } \\
\text { tion (selection bias) }\end{array}$ & Unclear risk & $\begin{array}{l}\text { Cluster-randomised, 2 groups in each workplace, researchers randomly as- } \\
\text { signed } 1 \text { to each condition, no further details }\end{array}$ \\
\hline $\begin{array}{l}\text { Allocation concealment } \\
\text { (selection bias) }\end{array}$ & Unclear risk & No details given \\
\hline $\begin{array}{l}\text { Blinding of participants } \\
\text { and personnel (perfor- } \\
\text { mance bias) }\end{array}$ & Unclear risk & Not specified \\
\end{tabular}


Schroter 2006 (Continued)

All outcomes

\begin{tabular}{|c|c|c|}
\hline $\begin{array}{l}\text { Blinding of outcome as- } \\
\text { sessment (detection bias) }\end{array}$ & Low risk & $\begin{array}{l}\text { No validation used, but similar amount of interaction in both groups suggest- } \\
\text { ed differential misreport unlikely }\end{array}$ \\
\hline
\end{tabular}

All outcomes

Incomplete outcome data Low risk $\quad 47 \%$ attrition reported, but all participants included in analyses

(attrition bias)

All outcomes

Secker-Walker 1995

\begin{tabular}{ll}
\hline Methods & $\begin{array}{l}\text { Setting: private and public prenatal clinics, USA } \\
\text { Recruitment: women at 1st prenatal visit }\end{array}$ \\
\hline Participants & $\begin{array}{l}165 \text { women previously smoking 1+ cigs/day who had quit since start of pregnancy (excluded } 10 \text { adverse } \\
\text { pregnancy outcomes) } \\
\text { Average age } 25\end{array}$ \\
\hline Interventions & $\begin{array}{l}\text { 1. Individual counselling focusing on pros and cons, problem solving, skills rehearsal. } 10 \text { to } 15 \text { minutes } \\
\text { at 1st, 2nd, and 3rd prenatal visit, } 36 \text { weeks and } 6 \text { weeks postpartum. (93\% received postpartum ses- } \\
\text { sion) }\end{array}$ \\
\hline $\begin{array}{l}\text { 2. Usual care control } \\
\text { Outcomes }\end{array}$ & $\begin{array}{l}\text { Abstinence at } 36 \text { weeks pregnancy (Analysis 1.1) and at } 8 \text { to } 54 \text { months postpartum (Analysis } 1.2) . \text { Fol- } \\
\text { low-up point varied } \\
\text { palidation: at } 36 \text { weeks, cotinine/creatinine ratio > } 80 \text { ng/mg, but some missing data, no validation } \\
\text { postpartum }\end{array}$ \\
\hline Notes & Sensitivity analysis excluding losses to follow-up did not alter results \\
\hline
\end{tabular}

\section{Risk of bias}

\begin{tabular}{lll}
\hline Bias & Authors' judgement & Support for judgement \\
\hline $\begin{array}{l}\text { Random sequence genera- } \\
\text { tion (selection bias) }\end{array}$ & Unclear risk & Randomisation method not stated \\
\hline $\begin{array}{l}\text { Allocation concealment } \\
\text { (selection bias) }\end{array}$ & Unclear risk & No details given \\
\hline $\begin{array}{l}\text { Blinding of participants } \\
\text { and personnel (perfor- } \\
\text { mance bias) }\end{array}$ & Unclear risk & $\begin{array}{l}\text { No details given, possible care providers were aware of participants' assign- } \\
\text { ment }\end{array}$ \\
\hline $\begin{array}{l}\text { Blinding of outcome as- } \\
\text { sessment (detection bias) }\end{array}$ & Unclear risk & $\begin{array}{l}\text { Self-report used postpartum and for some women at 36 weeks ("We includ- } \\
\text { ed the 40 women who reported not smoking, but were missing 36-week coti- } \\
\text { nine/creatinine ratios, in the non-smoking group, rather than count them as } \\
\text { having relapsed".) Reason for missing validation data at 36 weeks not report- } \\
\text { ed, group assignment of participants missing data not clear, differential misre- } \\
\text { port possible }\end{array}$ \\
\hline $\begin{array}{l}\text { Incomplete outcome data } \\
\text { (attrition bias) } \\
\text { All outcomes }\end{array}$ & $\begin{array}{l}\text { Unclear risk } \\
\text { No significant differences in loss to follow-up at 1 year (35\%). Numbers ran- } \\
\text { domly assigned used in analyses, but restricting to numbers available for fol- } \\
\text { low-up did not alter findings }\end{array}$ \\
\hline
\end{tabular}


Secker-Walker 1998

\begin{tabular}{|c|c|c|}
\hline Methods & \multicolumn{2}{|c|}{$\begin{array}{l}\text { Setting: prenatal clinic, USA } \\
\text { Recruitment: women at 1st prenatal visit }\end{array}$} \\
\hline Participants & \multicolumn{2}{|c|}{$\begin{array}{l}116 \text { women previously smoking } 1+\text { cigs/day who self-reported quitting since start of pregnancy (exclud- } \\
\text { ed } 9 \text { adverse pregnancy outcomes). } 19 \text { of the women showed evidence of smoking at 1st prenatal visit }\end{array}$} \\
\hline Interventions & \multicolumn{2}{|c|}{$\begin{array}{l}\text { 1. Structured intervention from physician, individual counselling by nurse counsellor, } 1 \mathrm{st}, 2 \mathrm{nd}, 3 \mathrm{rd}, 5 \mathrm{th} \text {, } \\
36 \text { weeks prenatal visits } \\
\text { 2. Usual care from physician, prompted at } 1 \text { st visit }\end{array}$} \\
\hline Outcomes & \multicolumn{2}{|c|}{$\begin{array}{l}\text { Sustained abstinence at } 36 \text { weeks pregnancy (Analysis 1.1), 1-year postpartum (Analysis 1.2) } \\
\text { Validation: } \mathrm{CO} \leq 6 \mathrm{ppm} \text { at } 36 \text { weeks, also urine cotinine } \leq 500 \mathrm{ng} / \mathrm{mL} \text { but some missing data }\end{array}$} \\
\hline Notes & \multicolumn{2}{|c|}{ Process analysis showed counselling to have been received fairly consistently but fell to $66 \%$ at 5 th visit } \\
\hline \multicolumn{3}{|l|}{ Risk of bias } \\
\hline Bias & Authors' judgement & Support for judgement \\
\hline $\begin{array}{l}\text { Random sequence genera- } \\
\text { tion (selection bias) }\end{array}$ & Unclear risk & Method not described \\
\hline $\begin{array}{l}\text { Allocation concealment } \\
\text { (selection bias) }\end{array}$ & Unclear risk & No details given \\
\hline $\begin{array}{l}\text { Blinding of participants } \\
\text { and personnel (perfor- } \\
\text { mance bias) } \\
\text { All outcomes }\end{array}$ & Unclear risk & No details given \\
\hline
\end{tabular}

\begin{tabular}{lll}
\hline $\begin{array}{l}\text { Blinding of outcome as- } \\
\begin{array}{l}\text { sessment (detection bias) } \\
\text { All outcomes }\end{array}\end{array}$ & Low risk & $\begin{array}{l}\text { Biochemical validation used at } 36 \text { weeks and differential misreport not iden- } \\
\text { tified. Similar rates abstinent at } 1 \text { year postpartum, differential misreport not } \\
\text { likely at final follow-up }\end{array}$ \\
\hline $\begin{array}{l}\text { Incomplete outcome data } \\
\text { (attrition bias) }\end{array}$ & Low risk & $\begin{array}{l}\text { No significant differences in loss to follow-up at 1 year (33\%). Numbers ran- } \\
\text { domly assigned, excluding adverse pregnancy outcomes used in denomina- } \\
\text { tors }\end{array}$
\end{tabular}

Segan 2011

\begin{tabular}{ll}
\hline Methods & Setting: Victoria, Australia Quitline \\
& Recruitment: callers to Quitline \\
\hline Participants & $\begin{array}{l}698 \text { smokers or recent ex-smokers calling Victoria, Australia, Quitline and abstinent for at least } 1 \text { week } \\
(1444 \text { randomly assigned, but study conducted only in those achieving abstinence) } \\
54 \% \text { female, average age 37, average cpd } 21\end{array}$ \\
\hline Interventions & $\begin{array}{l}\text { Participants received same callback service before quitting and same service in first month after quit- } \\
\text { ting (revised version of standard Quitline service: } 4 \text { calls in first month after quitting to help deal with } \\
\text { daily cravings and withdrawal). Service based on } 3 \text { Tasks of Quitting Framework. Both groups receive } \\
\text { counselling for first } 2 \text { tasks }\end{array}$
\end{tabular}


1. 4 to 6 additional calls 1 to 3 months post-quitting to actively assist with learning to enjoy and value a smoke-free lifestyle (task 3), initiated when participant reported fewer than daily cravings or completed 4 standard calls (whichever came first)

2. No additional calls

\begin{tabular}{ll}
\hline Outcomes & 12 months continuous abstinence \\
& Validation: none \\
\hline Notes & New for 2013 update \\
& n not provided, data extrapolated from percentages given. Only those participants abstinent for 1 week \\
& or longer included in final analyses \\
& $\begin{array}{l}74 \% \text { of intervention group received extra calls, on average } 1.7 \text { more calls after quitting than control } \\
\text { group }\end{array}$ \\
\hline
\end{tabular}

\section{Risk of bias}

\begin{tabular}{|c|c|c|}
\hline Bias & Authors' judgement & Support for judgement \\
\hline $\begin{array}{l}\text { Random sequence genera- } \\
\text { tion (selection bias) }\end{array}$ & Low risk & $\begin{array}{l}\text { "Randomization was controlled by an automated function in the Quitline } \\
\text { client management database" }\end{array}$ \\
\hline $\begin{array}{l}\text { Allocation concealment } \\
\text { (selection bias) }\end{array}$ & Low risk & Centralised, see above \\
\hline $\begin{array}{l}\text { Blinding of participants } \\
\text { and personnel (perfor- } \\
\text { mance bias) } \\
\text { All outcomes }\end{array}$ & High risk & $\begin{array}{l}\text { "Follow-up interviewers were blinded to participant treatment condition, } \\
\text { although for the four-month follow-up blinding was lost..." Participant and } \\
\text { provider unblinded }\end{array}$ \\
\hline $\begin{array}{l}\text { Blinding of outcome as- } \\
\text { sessment (detection bias) } \\
\text { All outcomes }\end{array}$ & Low risk & $\begin{array}{l}\text { No biochemical validation, but no face-to-face contact, so differential misre- } \\
\text { port judged to be unlikely }\end{array}$ \\
\hline $\begin{array}{l}\text { Incomplete outcome data } \\
\text { (attrition bias) } \\
\text { All outcomes }\end{array}$ & Low risk & $\begin{array}{l}\text { Similar rate lost to follow-up in both groups ( } 28 \% \text { control; } 30 \% \text { intervention), } \\
\text { participants lost to follow-up counted as smokers. Analysis excluding partici- } \\
\text { pants lost to follow-up did not affect final comparisons }\end{array}$ \\
\hline Other bias & High risk & $\begin{array}{l}\text { Probable lack of differentiation between the two conditions and risk of con- } \\
\text { tamination: "In practice, the first couple of integration callbacks typically re- } \\
\text { placed the last call or two of the standard service (rather than adding on to } \\
\text { it).... Usual care participants received on average 2.2. calls after reaching the } \\
\text { point of fewer than daily cravings, which provided ample opportunity for cont- } \\
\text { amination..." }\end{array}$ \\
\hline
\end{tabular}

\section{Severson 1997}

\begin{tabular}{ll}
\hline Methods & $\begin{array}{l}\text { Setting: } 49 \text { private paediatric practices, USA } \\
\text { Recruitment: mothers attending for well baby visits }\end{array}$ \\
\hline Participants & $\begin{array}{l}\text { 1026 ex-smoking mothers (intervention also given to smoking mothers, not relevant to this review) } \\
\text { Therapists: paediatricians. } \\
25 \text { intervention practices, } 23 \text { control }\end{array}$ \\
\hline
\end{tabular}


Severson 1997 (Continued)

Interventions
1. Information pack, including a letter from paediatrician on risks of passive smoking, provided by birth hospital, and extended support (counselling plus follow-up at 2, 4, and 5 months visits) and materials (including video tape, written materials, signs, magnets, bib)

2. Information pack only

$\begin{array}{ll}\text { Outcomes } & \begin{array}{l}\text { Sustained abstinence at } 12 \text { months (7-day point prevalence at } 6 \text { months and } 12 \text { months) } \\ \text { Validation: none }\end{array}\end{array}$

Notes

Study design allowed for clustering in calculating sample size. ICC proved to be low. Use of a corrected odds ratio, which did not show a significant benefit, did not change conclusions (sensitivity analysis using inverse variance)

\section{Risk of bias}

\begin{tabular}{|c|c|c|}
\hline Bias & Authors' judgement & Support for judgement \\
\hline $\begin{array}{l}\text { Random sequence genera- } \\
\text { tion (selection bias) }\end{array}$ & Unclear risk & Cluster-randomised by practice, method not described \\
\hline $\begin{array}{l}\text { Allocation concealment } \\
\text { (selection bias) }\end{array}$ & Unclear risk & $\begin{array}{l}\text { Method of allocating practices not described. All eligible patients enrolled in } \\
\text { study, "because the survey information was anonymous, and because smok- } \\
\text { ing counselling was considered to be standard medical practice, the study was } \\
\text { exempted from the requirements for obtaining informed consent" }\end{array}$ \\
\hline $\begin{array}{l}\text { Blinding of participants } \\
\text { and personnel (perfor- } \\
\text { mance bias) } \\
\text { All outcomes }\end{array}$ & Unclear risk & $\begin{array}{l}\text { Participants not aware enrolled in study, so blinding not applicable Unclear } \\
\text { whether study personnel (administering surveys) were blinded }\end{array}$ \\
\hline $\begin{array}{l}\text { Blinding of outcome as- } \\
\text { sessment (detection bias) } \\
\text { All outcomes }\end{array}$ & Low risk & $\begin{array}{l}\text { No biochemical validation but cluster-randomised by practice, followed up } \\
\text { anonymously via survey, differential misreport unlikely }\end{array}$ \\
\hline $\begin{array}{l}\text { Incomplete outcome data } \\
\text { (attrition bias) } \\
\text { All outcomes }\end{array}$ & Low risk & $\begin{array}{l}\text { Losses to follow-up ( } 31 \% \text { in each group) assumed to have relapsed, attrition } \\
\text { analyses performed }\end{array}$ \\
\hline
\end{tabular}

\section{Sheffer 2010}

$\begin{array}{ll}\text { Methods } & \text { Setting: Quitline for Arkansas, USA } \\ & \text { Recruitment: all participants calling the Quitline within a set amount of time were included }\end{array}$

$\begin{array}{ll}\text { Participants } & \text { All Arkansas Quitline callers whose primary form of tobacco use was smoking who ended treatment } \\ \text { (completing treatment or ending prematurely) within the set period and did not re-enter counselling } \\ \text { within } 2 \text { years of index episode }(n=892)\end{array}$

$35 \%$ male, average age 43 , average cpd not specified, mean FTND 7

Interventions

1. Intervention: 8 "Forever Free" booklets (aimed at relapse prevention) mailed to all Quitline callers who ended treatment (within given 6 weeks period)

2. Nothing mailed to callers (all participants who consecutively ended treatment 1 month before or 1 month after intervention group) 
Sheffer 2010 (Continued)

All participants received standard Quitline service (average 6 weekly structured CBT sessions 20 to 30 mins each); nicotine patches provided free of charge

\begin{tabular}{ll}
\hline Outcomes & 7-day point prevalence at 6 months after discontinuation of treatment \\
& Validation: none \\
\hline Notes & New for 2013 update \\
& Quasi-randomised; baseline imbalances between groups, adjusted OR available \\
& Intervention did not improve quit rates for participants receiving at least 1 session of counselling and \\
& nicotine patches but doubled abstinence rate for those unwilling/unable to receive nicotine patches at \\
& months \\
& n not provided, extrapolated from percentages reported
\end{tabular}

\section{Risk of bias}

\begin{tabular}{lll}
\hline Bias & Authors' judgement & Support for judgement \\
\hline $\begin{array}{l}\text { Random sequence genera- } \\
\text { tion (selection bias) }\end{array}$ & High risk & $\begin{array}{l}\text { Quasi-randomised. "The 'Forever Free' booklets were mailed to all quitline } \\
\text { callers who ended treatment during a six-week period. For comparison, we in- } \\
\text { cluded quitline callers whose treatment ended during the months immediate- } \\
\text { ly prior and succeeding the 6-week intervention period" }\end{array}$ \\
\hline
\end{tabular}

\begin{tabular}{|c|c|c|}
\hline $\begin{array}{l}\text { Allocation concealment } \\
\text { (selection bias) }\end{array}$ & High risk & See above \\
\hline $\begin{array}{l}\text { Blinding of participants } \\
\text { and personnel (perfor- } \\
\text { mance bias) } \\
\text { All outcomes }\end{array}$ & Low risk & $\begin{array}{l}\text { "Quitline staff including tobacco treatment specialists and follow-up inter- } \\
\text { viewers were unaware that some participants had received additional materi- } \\
\text { als" }\end{array}$ \\
\hline
\end{tabular}

Blinding of outcome as- Low risk sessment (detection bias) All outcomes
No biochemical validation but no additional personalised contact received by intervention group, so differential levels of misreport unlikely
Incomplete outcome data Low risk

(attrition bias)

All outcomes
Similar rates of dropout in both groups (34.7\% intervention, $40.0 \%$ control); participants lost to follow-up counted as smokers

\section{Shoptaw 2002}

\begin{tabular}{ll}
\hline Methods & $\begin{array}{l}\text { Setting: three narcotics treatment centres, USA } \\
\text { Recruitment: volunteers on methadone maintenance }\end{array}$ \\
\hline Participants & 175 smokers ( $\geq 10 /$ day); $33 \%$ female, average age 43 to 45, average cigs/day approximately 22 \\
\hline Interventions & $\begin{array}{l}\text { All participants received } 21 \mathrm{mg} \text { nicotine patch for } 12 \text { weeks. Factorial design crossing contingency man- } \\
\text { agement, arms collapsed } \\
\text { 1. Group counselling: } 12 \times 1 \text { hour weekly sessions, including mood management }\end{array}$ \\
2. Control: NRT alone
\end{tabular}

Outcomes

PP abstinence at 12 months

Validation: $\mathrm{CO} \leq 8 \mathrm{ppm}$, urine cotinine $<30 \mathrm{ng} / \mathrm{mL}$ 
Shoptaw 2002 (Continued)

Notes

\section{Risk of bias}

\begin{tabular}{|c|c|c|}
\hline Bias & Authors' judgement & Support for judgement \\
\hline $\begin{array}{l}\text { Random sequence genera- } \\
\text { tion (selection bias) }\end{array}$ & Low risk & Randomisation using urn technique \\
\hline $\begin{array}{l}\text { Allocation concealment } \\
\text { (selection bias) }\end{array}$ & Low risk & $\begin{array}{l}\text { Not described but use of urn technique made it probable that allocation con- } \\
\text { cealed }\end{array}$ \\
\hline $\begin{array}{l}\text { Blinding of participants } \\
\text { and personnel (perfor- } \\
\text { mance bias) } \\
\text { All outcomes }\end{array}$ & Unclear risk & Not reported \\
\hline $\begin{array}{l}\text { Blinding of outcome as- } \\
\text { sessment (detection bias) } \\
\text { All outcomes }\end{array}$ & Low risk & Biochemical validation used \\
\hline $\begin{array}{l}\text { Incomplete outcome data } \\
\text { (attrition bias) } \\
\text { All outcomes }\end{array}$ & Low risk & $\begin{array}{l}\text { Number lost to follow-up not reported, but all missing included as smokers, } \\
\text { and study reported, "no statistically significant differences across the four } \\
\text { treatment conditions for breath samples and urine samples" }\end{array}$ \\
\hline
\end{tabular}

Simmons 2018

\begin{tabular}{ll}
\hline Methods & Setting: Mailed interventions, USA \\
& Recruitment: Nationally via multiple recruitment strategies (newspapers, radio, public transit, cable TV, \\
public service announcements) publicising cessation materials for current smokers interested in quit- \\
ting
\end{tabular}

Participants 1874 smokers: Traditional Self Help (TSH, $n=638)$, Standard Repeated Mailings (SRM, $n=614)$, Intensive Repeated Mailings (IRM, $n=622$ )

$34 \%$ male, average age 47.5 , average cigs/day 20.5

Interventions $\quad$ 1. Intensive repeated mailings - 10 smoking cessation booklets and additional social support material over 18 months

2. Standard repeated mailings -8 smoking cessation booklets over 12 months

Control: Traditional self-help - one self-help smoking cessation booklet

\begin{tabular}{ll}
\hline Outcomes & Self-report 7-d PP abstinence at 30 months \\
\hline Notes & $\begin{array}{l}\text { Funding: a grant from the National Cancer Institute } \\
\text { Declaration of interests: H. Brandon has received research support from Pfizer, Inc. }\end{array}$
\end{tabular}

\section{Risk of bias}

\begin{tabular}{lll}
\hline Bias & Authors' judgement & Support for judgement \\
\hline $\begin{array}{l}\text { Random sequence genera- } \\
\text { tion (selection bias) }\end{array}$ & Unclear risk & No method stated \\
\hline
\end{tabular}


Simmons 2018 (Continued)

\begin{tabular}{|c|c|c|}
\hline $\begin{array}{l}\text { Allocation concealment } \\
\text { (selection bias) }\end{array}$ & Unclear risk & Not stated \\
\hline $\begin{array}{l}\text { Blinding of participants } \\
\text { and personnel (perfor- } \\
\text { mance bias) } \\
\text { All outcomes }\end{array}$ & Low risk & $\begin{array}{l}\text { Not stated but due to remote nature of intervention (mailing), performance } \\
\text { bias was unlikely. }\end{array}$ \\
\hline $\begin{array}{l}\text { Blinding of outcome as- } \\
\text { sessment (detection bias) } \\
\text { All outcomes }\end{array}$ & Low risk & $\begin{array}{l}\text { Follow-up assessments completed by participants - self-report and self-doc- } \\
\text { umented. Due to remote nature of intervention (mailing), detection bias was } \\
\text { unlikely. }\end{array}$ \\
\hline $\begin{array}{l}\text { Incomplete outcome data } \\
\text { (attrition bias) } \\
\text { All outcomes }\end{array}$ & Unclear risk & $\begin{array}{l}\text { Quote: "The percent of surveys not returned increased from } 27 \% \text { at } 6 \text { months } \\
\text { to } 46 \% \text { at } 30 \text { months." }\end{array}$ \\
\hline
\end{tabular}

Smith 2001

\begin{tabular}{ll}
\hline Methods & $\begin{array}{l}\text { Setting: Clinic, USA } \\
\text { Recruitment: community volunteers }\end{array}$ \\
\hline Participants & $\begin{array}{l}67 \text { smokers ( }>10 / \text { day) attempted quit for } 1 \text { week; } 57 \% \text { female, average age 42; average cigs/day ap- } \\
\text { proximately } 25\end{array}$ \\
\hline Interventions & $\begin{array}{l}\text { All participants had attended } 3 \text { brief }(5 \text { to } 10 \mathrm{~min}) \text { individual counselling sessions pre-quit, quit day and } \\
\text { 1. Cognitive-behavioural skills training, } \times 6 \text { from } 1 \text { week post TQD, including managing negative affect, } \\
\text { homework, manual } \\
\text { 2. Motivational interviewing, supportive group counselling, } \times 6 \text { from } 1 \text { week post TQD. No homework or } \\
\text { manual } \\
\text { 3. No further intervention }\end{array}$ \\
\hline
\end{tabular}

\begin{tabular}{ll}
\hline Outcomes & $\begin{array}{l}\text { Abstinence at } 12 \text { months (7-d PP) } \\
\text { Validation: } \mathrm{CO}<10 \mathrm{ppm}\end{array}$ \\
\hline Notes & $\begin{array}{l}1 \text { versus } 3 \text { in Analysis 4.1, including } 2, \text { did not alter findings; } 17.6 \% \text { quit in } 1,18.8 \% \text { in } 2 . \text { No evidence } \\
\text { found for hypothesised differences in relative efficacy for smokers at high or low risk of relapse. High- } \\
\text { risk smokers expected to do better with motivational intervention }\end{array}$
\end{tabular}

\section{Risk of bias}

\begin{tabular}{lll}
\hline Bias & Authors' judgement & Support for judgement \\
\hline $\begin{array}{l}\text { Random sequence genera- } \\
\text { tion (selection bias) }\end{array}$ & Unclear risk & $\begin{array}{l}\text { Randomly assigned 1 week after TQD, stratified by } \pm \text { any smoking post TQD. } \\
\text { Method not stated }\end{array}$ \\
\hline $\begin{array}{l}\text { Allocation concealment } \\
\text { (selection bias) }\end{array}$ & Unclear risk & No details given \\
\hline $\begin{array}{l}\text { Blinding of participants } \\
\text { and personnel (perfor- } \\
\text { mance bias) } \\
\begin{array}{l}\text { All outcomes } \\
\text { Blinding of outcome as- } \\
\text { sessment (detection bias) }\end{array}\end{array}$ & Unclear risk & $\begin{array}{l}\text { Participants randomly assigned after receiving pre-quit interventions. No fur- } \\
\text { ther details provided }\end{array}$ \\
\hline
\end{tabular}


Smith 2001 (Continued)

All outcomes

Incomplete outcome data Unclear risk Number lost to follow-up not reported, all missing included as smokers
(attrition bias)
(attrition bias)

All outcomes

\begin{tabular}{|c|c|c|}
\hline Methods & \multicolumn{2}{|c|}{$\begin{array}{l}\text { Setting: HMO, USA } \\
\text { Recruitment: HMO member volunteers }\end{array}$} \\
\hline Participants & \multicolumn{2}{|c|}{$\begin{array}{l}587 \text { smokers who successfully abstained from smoking for } 4 \text { days after a 4-day intensive cessation pro- } \\
\text { gramme }\end{array}$} \\
\hline Interventions & \multicolumn{2}{|c|}{$\begin{array}{l}\text { Both group conditions met for } 3 \times 2 \text { hours weekly meetings } \\
\text { 1. Skills condition. Development and active rehearsal of coping strategies } \\
\text { 2. Discussion condition. Social support meetings without rehearsal of strategies } \\
\text { 3. No further treatment control }\end{array}$} \\
\hline Outcomes & \multicolumn{2}{|c|}{$\begin{array}{l}\text { Abstinence at } 1 \text { year, no tobacco use in previous } 6 \text { months } \\
\text { Validation: saliva thiocyanate }<0.8 \mathrm{mg} / \mathrm{mL} \text { or cotinine }<5 \mathrm{ng} / \mathrm{mL}\end{array}$} \\
\hline Notes & \multicolumn{2}{|c|}{ Study hypothesis that discussion control would not increase rates, so in main analysis 1 versus $2+3$} \\
\hline \multicolumn{3}{|l|}{ Risk of bias } \\
\hline Bias & Authors' judgement & Support for judgement \\
\hline $\begin{array}{l}\text { Random sequence genera- } \\
\text { tion (selection bias) }\end{array}$ & Low risk & Predetermined random number list \\
\hline $\begin{array}{l}\text { Allocation concealment } \\
\text { (selection bias) }\end{array}$ & Unclear risk & $\begin{array}{l}\text { Not explicit that list concealed, although likelihood of selection bias judged to } \\
\text { be small }\end{array}$ \\
\hline $\begin{array}{l}\text { Blinding of participants } \\
\text { and personnel (perfor- } \\
\text { mance bias) } \\
\text { All outcomes }\end{array}$ & Unclear risk & $\begin{array}{l}\text { Subjects randomly assigned after initial treatment phase, no further informa- } \\
\text { tion provided }\end{array}$ \\
\hline $\begin{array}{l}\text { Blinding of outcome as- } \\
\text { sessment (detection bias) } \\
\text { All outcomes }\end{array}$ & Low risk & $\begin{array}{l}\text { Biochemical validation used. Staff following up non-attenders at } 1 \text { year meet- } \\
\text { ing blind to treatment assignment }\end{array}$ \\
\hline $\begin{array}{l}\text { Incomplete outcome data } \\
\text { (attrition bias) } \\
\text { All outcomes }\end{array}$ & Low risk & $\begin{array}{l}\text { Loss to follow-up } 6.6 \% \text { overall, non-significantly higher in control. Dropouts in- } \\
\text { cluded in analysis }\end{array}$ \\
\hline
\end{tabular}

\section{STRATUS-WW 2006}

\begin{tabular}{ll}
\hline Methods & $\begin{array}{l}\text { Setting: Australia, Canada, USA, setting type not reported but presumably clinic } \\
\text { Recruitment: } \text { not stated }\end{array}$ \\
\hline Participants & $\begin{array}{l}5055 \text { adult smokers }(>18) \text { motivated to quit. Randomly assigned to rimonabant } 5 \mathrm{mg}(\mathrm{n}=2026) \text { or ri- } \\
\text { monabant } 20 \mathrm{mg}(\mathrm{n}=3029)\end{array}$ \\
\hline
\end{tabular}


STRATUS-WW 2006 (Continued)

$50 \%$ male, $88.8 \%$ female, mean age 44.1, average CPD 23.6, mean year smoking 24.1, mean quit attempts 4.1, mean FTND score 5.4, 31.7\% with FTND score > 7. Mean BMI 27.8

Interventions

Phase 1: cessation trial: participants randomly assigned to rimonabant $5 \mathrm{mg}$ [R5] ( $\mathrm{n}=2026)$ or rimonabant $20 \mathrm{mg}$ [R20] ( $\mathrm{n}=3029)$ for 10 weeks, with TQD at day 15. Cessation rates at EOT: R5: 644/2026 (31.8\%); R20 1017/3029 (33.6\%), difference non-significant; Quitters eligible for phase 2 if: (a) self-reported abstinence for 7+ days, (b) $\mathrm{CO} \leq 10 \mathrm{ppm}$, and (c) compliance level of $80 \%+$ in last 4 weeks of phase 1

Phase 2: Relapse prevention: re-randomly assigned 644 quitters in R5 group to (i) R5 ( $n=322$ ) or (ii) placebo ( $n=322$ ), and 1017 quitters in R20 group to (i) R5 ( $=335$ ) or (ii) R20 ( $=340)$ or (iii) placebo ( = 342). All groups received treatment for a further 42 weeks

Behavioural support: not reported

$\begin{array}{ll}\text { Outcomes } & \text { Primary outcome: time to relapse for quitters from weeks } 10 \text { to } 32 \text {. Relapse defined as } \geq 7 \text { consecutive } \\ & \text { days of smoking (even a puff), or } \geq 2 \text { consecutive days with } \geq 5 \text { cigs (even a puff) smoked per day } \\ \text { Long-term follow-up: } 52 \text { weeks, } 104 \text { weeks } & \\ & \text { Secondary outcome: time to relapse for quitters from week } 10 \text { to week } 52 \\ & \text { Other outcomes: weight change; fasting HDL-cholesterol, triglycerides; safety, adverse events } \\ & \text { Validation: phase } 1 \text { : expired CO < } 10 \text { ppm; phase } 2 \text { : not reported }\end{array}$

Notes
New for 2013
Two-year follow-up data were not reported. Results not published and hence are limited, data not
available on phase $1 \mathrm{R} 5$ group
Trial was funded by the manufacturer, Sanofi Aventis
Percentage abstinent at 12 months very similar in R5 and R20 phase II groups (41.8 vs 41.5$),$ combined
in meta-analysis

\section{Risk of bias}

\begin{tabular}{|c|c|c|}
\hline Bias & Authors' judgement & Support for judgement \\
\hline $\begin{array}{l}\text { Random sequence genera- } \\
\text { tion (selection bias) }\end{array}$ & Unclear risk & Not stated \\
\hline $\begin{array}{l}\text { Allocation concealment } \\
\text { (selection bias) }\end{array}$ & Unclear risk & Not stated \\
\hline $\begin{array}{l}\text { Blinding of participants } \\
\text { and personnel (perfor- } \\
\text { mance bias) } \\
\text { All outcomes }\end{array}$ & Unclear risk & "Double-blind", no further information provided \\
\hline $\begin{array}{l}\text { Blinding of outcome as- } \\
\text { sessment (detection bias) } \\
\text { All outcomes }\end{array}$ & Unclear risk & No information reported \\
\hline $\begin{array}{l}\text { Incomplete outcome data } \\
\text { (attrition bias) } \\
\text { All outcomes }\end{array}$ & Unclear risk & Not reported \\
\hline
\end{tabular}

Tonstad 2006

$\begin{array}{ll}\text { Methods } & \text { Setting: cessation clinics in } 7 \text { countries. } 6 \text { sites in United States } \\ & \text { Recruitment: smokers of } \geq 10 / \text { day for cessation phase }\end{array}$


Tonstad 2006 (Continued)

Participants

1210 adults previously smoking $\geq 10 /$ day, quit for at least 1 week after 12 weeks open-label varenicline

\begin{tabular}{ll}
\hline Interventions & $\begin{array}{l}\text { 1. Varenicline } 1 \mathrm{mg} \times 2 \text { daily for } 12 \text { weeks with } 5 \text { clinic visits } \\
\text { 2. Placebo }\end{array}$ \\
\hline Outcomes & $\begin{array}{l}\text { Sustained abstinence for } 9 \text { months at } 1 \text { year } \\
\text { Validation: } \mathrm{CO} \geq 10 \mathrm{ppm}\end{array}$ \\
\hline Notes & The quit rate after the open-label phase was $64 \%$
\end{tabular}

\section{Risk of bias}

\begin{tabular}{|c|c|c|}
\hline Bias & Authors' judgement & Support for judgement \\
\hline $\begin{array}{l}\text { Random sequence genera- } \\
\text { tion (selection bias) }\end{array}$ & Low risk & Centralised computer-generated randomisation \\
\hline $\begin{array}{l}\text { Allocation concealment } \\
\text { (selection bias) }\end{array}$ & Low risk & Based on use of centralised allocation \\
\hline $\begin{array}{l}\text { Blinding of participants } \\
\text { and personnel (perfor- } \\
\text { mance bias) } \\
\text { All outcomes }\end{array}$ & Low risk & $\begin{array}{l}\text { "Double-blind treatment phase"; "participant blinding was maintained during } \\
\text { this [non-treatment follow-up] phase" }\end{array}$ \\
\hline $\begin{array}{l}\text { Blinding of outcome as- } \\
\text { sessment (detection bias) } \\
\text { All outcomes }\end{array}$ & Low risk & Double-blind and biochemical validation used \\
\hline $\begin{array}{l}\text { Incomplete outcome data } \\
\text { (attrition bias) } \\
\text { All outcomes }\end{array}$ & Low risk & $\begin{array}{l}\text { Higher loss to follow-up in controls due to relapse, dropouts counted as smok- } \\
\text { ers }\end{array}$ \\
\hline
\end{tabular}

Unrod 2016

\begin{tabular}{ll}
\hline Methods & Setting: home-based, USA \\
& Recruitment: clients of New York Smokers' Quitline \\
\hline Participants & 3458 smokers, 1142 repeated mailing, 1127 mass mailing, 1189 control \\
& $49.3 \%$ male, average age 46, average cigs/day 17 \\
\hline Interventions & Repeated mailings: Eight 'Forever Free' booklets mailed over 12 months \\
& Mass mailings: Eight 'Forever Free' booklets mailed upon enrolment \\
& Control: Standard mail intervention \\
\hline Outcomes & 7-day point prevalence abstinence at 24 months \\
& Validation: Not described \\
\hline Notes & $\begin{array}{l}\text { Funding: "National Cancer Institute of the National Institutes of Health under award number } \\
\text { Facilities at the H. Lee Moffitt Cancer Center and Research Institute, an NCI designated Comprehensive } \\
\text { Cancer Center (P30CA76292)." }\end{array}$ \\
\hline
\end{tabular}


Declaration of interests: "THB has received research support from Pfizer, Inc. KMC has received grant funding from the Pfizer Corporation to study the impact of a hospital based tobacco cessation intervention. He also receives funding as an expert witness in litigation filed against the tobacco industry. No other financial disclosures or conflicts of interest were reported by the authors of this paper."

\section{Risk of bias}

\begin{tabular}{lll}
\hline Bias & Authors' judgement & Support for judgement \\
\hline $\begin{array}{l}\text { Random sequence genera- } \\
\text { tion (selection bias) }\end{array}$ & Low risk & Computerised randomisation performed \\
\hline $\begin{array}{l}\text { Allocation concealment } \\
\text { (selection bias) }\end{array}$ & Unclear risk & Concealment not described \\
\hline $\begin{array}{l}\text { Blinding of participants } \\
\begin{array}{l}\text { and personnel (perfor- } \\
\text { mance bias) }\end{array}\end{array}$ & Low risk & $\begin{array}{l}\text { Blinding could not be performed because of the nature of the intervention, but } \\
\text { All outcomes }\end{array}$ \\
\hline
\end{tabular}

Blinding of outcome as- High risk sessment (detection bias)

All outcomes Blinding not performed and abstinence not biochemically verified

Incomplete outcome data Low risk Dropout rates equivalent across groups
(attrition bias)
All outcomes

\section{Van Osch 2008}

\begin{tabular}{ll}
\hline Methods & Setting: participants in national Quit and Win contest, Netherlands \\
& Recruitment: email to Quit and Win participants \\
\hline Participants & $\begin{array}{l}1566 \text { participants in national Quit \& Win contest (daily smokers, smoking for at least } 1 \text { year, } 18 \text { years or } \\
\text { older) } \\
60.8 \% \text { female, average age 36.2, average cpd 18.5, average length of smoking } 19.1 \text { years }\end{array}$ \\
\hline Interventions & $\begin{array}{l}\text { Quit and Win contest included 1-month cessation period, including computer-tailored cessation advice } \\
\text { Intervention: participants asked to formulate three coping plans when completing baseline survey } \\
\text { Control: baseline survey only (not prompted to formulate coping strategies) }\end{array}$ \\
\hline Cutcomes & $\begin{array}{l}\text { Continuous abstinence and 7-d PP at } 7 \text { months } \\
\text { would be performed for contest winners }\end{array}$ \\
\hline New for 2013 update \\
Unclear how abstinence data were obtained \\
Including only respondents increased evidence of effect
\end{tabular}

\section{Risk of bias}


Van Osch 2008 (Continued)

\begin{tabular}{|c|c|c|}
\hline Bias & Authors' judgement & Support for judgement \\
\hline $\begin{array}{l}\text { Random sequence genera- } \\
\text { tion (selection bias) }\end{array}$ & High risk & "Based on odd or even registration numbers" \\
\hline $\begin{array}{l}\text { Allocation concealment } \\
\text { (selection bias) }\end{array}$ & Unclear risk & $\begin{array}{l}\text { Centralised, but unclear whether participants aware of their registration num- } \\
\text { bers }\end{array}$ \\
\hline $\begin{array}{l}\text { Blinding of participants } \\
\text { and personnel (perfor- } \\
\text { mance bias) } \\
\text { All outcomes }\end{array}$ & Low risk & $\begin{array}{l}\text { No blinding reported, but because of the nature of the intervention, perfor- } \\
\text { mance bias unlikely }\end{array}$ \\
\hline $\begin{array}{l}\text { Blinding of outcome as- } \\
\text { sessment (detection bias) } \\
\text { All outcomes }\end{array}$ & Low risk & $\begin{array}{l}\text { 'Buddy' validation and knowledge of biochemical validation would be used } \\
\text { for any contest winners, nature of intervention made differential misreport un- } \\
\text { likely }\end{array}$ \\
\hline $\begin{array}{l}\text { Incomplete outcome data } \\
\text { (attrition bias) } \\
\text { All outcomes }\end{array}$ & High risk & $\begin{array}{l}\text { Very high rates of dropout at } 7 \text { months ( } 64 \% \text { control, } 63 \% \text { intervention). "The } \\
\text { relatively high attrition suffered across the two follow-up measurements may } \\
\text { restrict validity of the results and may have caused biases in reported absti- } \\
\text { nence rates" }\end{array}$ \\
\hline
\end{tabular}

\section{Van't Hof 2000}

\begin{tabular}{ll} 
Methods & $\begin{array}{l}\text { Setting: six hospitals, USA } \\
\text { Recruitment: women at time of delivery }\end{array}$ \\
\hline Participants & $\begin{array}{l}277 \text { women who had quit during pregnancy, cotinine verified as not smoking at recruitment (excluded } \\
10 \text { not followed up for a variety of reasons). Average age } 25, \text { previous cigs/day not reported. } 65 \% \text { were } \\
\text { very confident of remaining quit }\end{array}$ \\
\hline
\end{tabular}

Interventions 15 min to 30 min of relapse prevention counselling from Visiting Nurse after baseline interview. Rein-
forcement by paediatric care provider at 2 weeks, 2 months, 4 months well baby clinics, written materi-
als. Chart sticker used to prompt intervention
2. Usual care, baseline assessment from Visiting Nurse

$\begin{array}{ll}\text { Outcomes } & \text { Abstinence at } 6 \text { months (assume PP) } \\ \text { Validation: none (assessment by phone, no details of blinding of assessor) }\end{array}$

Notes

\section{Risk of bias}

\begin{tabular}{lll}
\hline Bias & Authors' judgement & Support for judgement \\
\hline $\begin{array}{l}\text { Random sequence genera- } \\
\text { tion (selection bias) }\end{array}$ & Unclear risk & Randomised, method not described \\
\hline $\begin{array}{l}\text { Allocation concealment } \\
\text { (selection bias) }\end{array}$ & Unclear risk & No details given \\
\hline $\begin{array}{l}\text { Blinding of participants } \\
\text { and personnel (perfor- } \\
\text { mance bias) }\end{array}$ & Unclear risk & No details given \\
All outcomes & \\
\hline
\end{tabular}


Van't Hof 2000 (Continued)

Blinding of outcome as- High risk No biochemical validation, intervention participants received more face-tosessment (detection bias) face contact than control group, no details of blinding of assessor, differential All outcomes misreport possible

Incomplete outcome data Low risk (attrition bias)

A sensitivity analysis including losses to follow-up did not change direction or

All outcomes

significance of effect

Veldheer 2018

$\begin{array}{ll}\text { Methods } & \text { Setting: University affiliated outpatient medical practices, USA } \\ & \text { Recruitment: Via posters and clinician referrals to attend smoking cessation group treatment }\end{array}$

Participants

115 previous smokers who had quit in the first part of the study; $40 \%$ male, average age 50 , average cigs/day 15.5

Interventions

Intervention: 8 self-directed relapse prevention materials

Control: 1 information booklet on cigarettes (with no advice on quitting/relapse prevention)

\begin{tabular}{ll}
\hline Outcomes & 7-day PP abstinence \\
& Validation: Exhaled carbon monoxide \\
\hline Notes & Funding: internal grant from Penn State Cancer Institute to JF. JF, SV, JY, and SH are primarily funded \\
by the National Institute on Drug Abuse of the National Institutes of Health and the Center for Tobacco & Products of the U.S. Food and Drug Administration. \\
& Declaration of interests: JF has done paid consulting for pharmaceutical companies involved in pro- \\
& ducing smoking cessation medications, including GSK, Pfizer, Novartis, J \& J, and Cypress Bioscience. \\
& The other authors have no conflicts of interest to disclose.
\end{tabular}

\section{Risk of bias}

\begin{tabular}{lll}
\hline Bias & Authors' judgement & Support for judgement \\
\hline $\begin{array}{l}\text { Random sequence genera- } \\
\text { tion (selection bias) }\end{array}$ & Unclear risk & Method not described \\
\hline $\begin{array}{l}\text { Allocation concealment } \\
\text { (selection bias) }\end{array}$ & Unclear risk & Not described \\
\hline $\begin{array}{l}\text { Blinding of participants } \\
\text { and personnel (perfor- } \\
\text { mance bias) }\end{array}$ & Low risk & Participants were unaware of other conditions and received similar levels of \\
All outcomes & contact, so performance bias was unlikely. \\
\hline $\begin{array}{l}\text { Blinding of outcome as- } \\
\text { sessment (detection bias) } \\
\text { All outcomes }\end{array}$ & Low risk & Abstinence was biochemically validated. \\
\hline $\begin{array}{l}\text { Incomplete outcome data } \\
\text { (attrition bias) } \\
\text { All outcomes }\end{array}$ & Low risk & 27 dropouts, similar across conditions \\
\hline
\end{tabular}


Wetter 2011

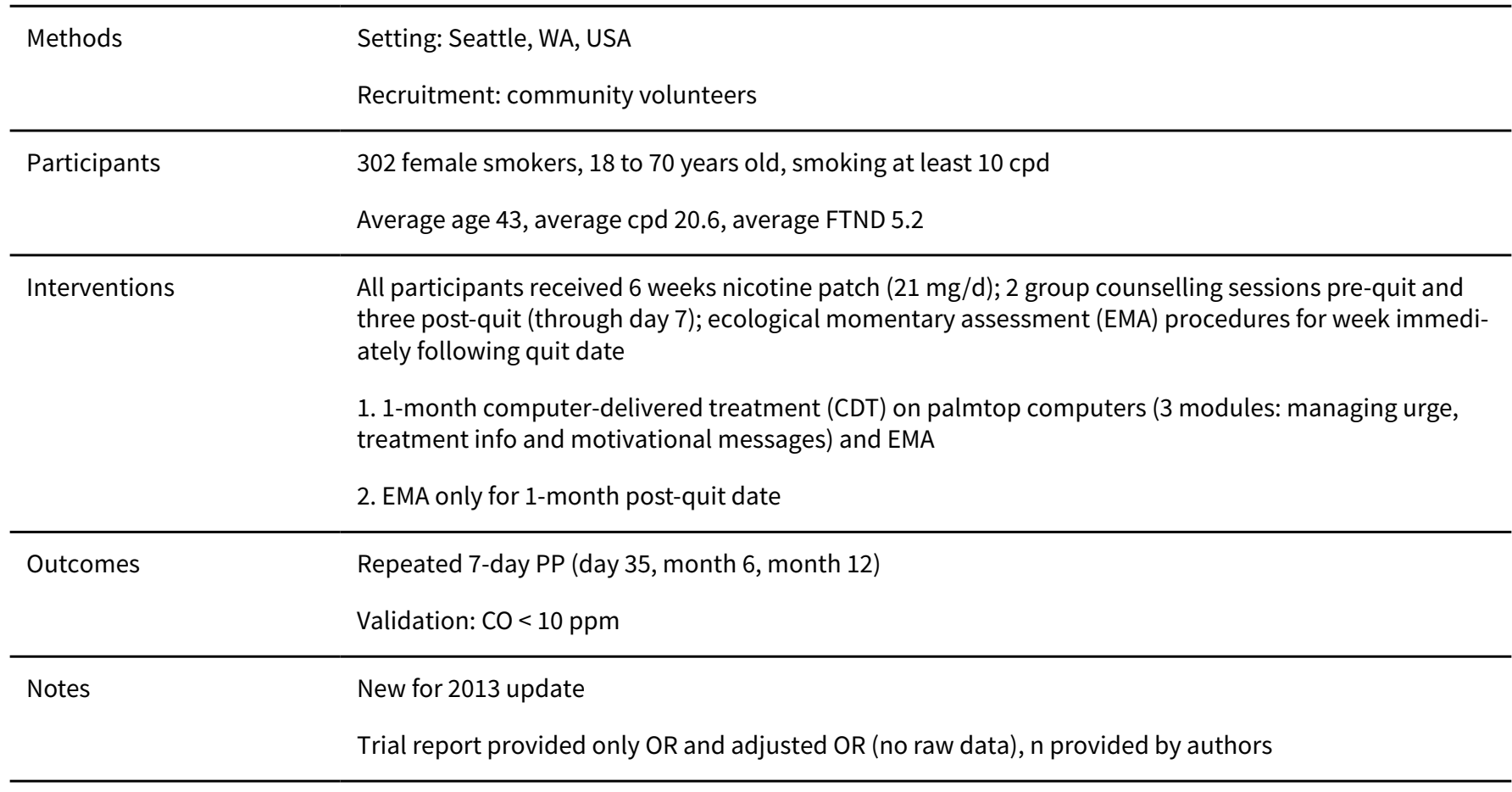

\section{Risk of bias}

\begin{tabular}{|c|c|c|}
\hline Bias & Authors' judgement & Support for judgement \\
\hline $\begin{array}{l}\text { Random sequence genera- } \\
\text { tion (selection bias) }\end{array}$ & Low risk & "the study biostatistician generated the randomization sequence" \\
\hline $\begin{array}{l}\text { Allocation concealment } \\
\text { (selection bias) }\end{array}$ & Unclear risk & Method not specified \\
\hline $\begin{array}{l}\text { Blinding of participants } \\
\text { and personnel (perfor- } \\
\text { mance bias) } \\
\text { All outcomes }\end{array}$ & Unclear risk & $\begin{array}{l}\text { Blinding not specified, unclear whether participants aware of additional ele- } \\
\text { ment offered to intervention group }\end{array}$ \\
\hline $\begin{array}{l}\text { Blinding of outcome as- } \\
\text { sessment (detection bias) } \\
\text { All outcomes }\end{array}$ & Low risk & Smoking status biochemically validated \\
\hline $\begin{array}{l}\text { Incomplete outcome data } \\
\text { (attrition bias) } \\
\text { All outcomes }\end{array}$ & Low risk & $\begin{array}{l}\text { Dropouts counted as smokers in ITT analysis, similar number lost to follow-up } \\
\text { in each group at } 12 \text { months ( } 21 \text { dropouts control, } 19 \text { dropouts treatment) }\end{array}$ \\
\hline
\end{tabular}

$A L A=$ American Lung Association

$\mathrm{BMI}=$ body mass index

BMT = basic military training

$\mathrm{BS}=$ Broad-spectrum

$\mathrm{CABG}=$ coronary artery bypass graft

$C A D=$ coronary artery disease

$\mathrm{CBT}=$ cognitive-behavioural therapy

$\mathrm{CDT}=$ computer-delivered treat

CHESS SCRP = Comprehensive Health Enhancement Support System for Smoking Cessation and Relapse Prevention 
$\mathrm{CO}=$ carbon monoxide

$\mathrm{cpd}=$ cigarettes per day

EMA = ecological momentary assessment

EOT $=$ end of treatment

FTND = Fagerström Test for Nicotine Dependence

FTQ = Fagerström Tolerance Questionnaire

$\mathrm{HMO}=$ health maintenance organisation

ICC = Intraclass correlation

ITT = intention to treat

MAPS; MAPS+ = Motivation and Problem-Solving; Motivation and Problem-Solving+

$M D D=$ major depressive disorder

$\mathrm{MI}=$ myocardial infarction

$\min =$ minutes

$\mathrm{NCl}=$ National Cancer Institute

NHS = National Health Service

NRT = nicotine replacement therapy

NS = not stated

$\mathrm{PA}=$ partner-assisted

$\mathrm{PP}=$ point prevalence abstinence (abstinent at that time but not necessarily continuously since treatment)

$\mathrm{PPC}=$ proactive phone counselling

ppm $=$ parts per million

PTSD = post traumatic stress disorder

$\mathrm{RCT}=$ randomised controlled trial

TEQ-20; TEQ-10 = Technology Enhanced Quitline-20; Technology Enhanced Quitline-10

TQD = target quit day

UC = usual care

WGC = workplace group counselling

WO = women only

Characteristics of excluded studies [ordered by study ID]

\begin{tabular}{|c|c|}
\hline Study & Reason for exclusion \\
\hline ACTRN12618000408280 & No appropriate comparator \\
\hline Adams 2011 & Only 2 months follow-up \\
\hline Allen 2007 & Only 12 weeks follow-up \\
\hline Alterman 2001 & $\begin{array}{l}\text { Considered for inclusion because comparison of different intensity interventions. No mention of re- } \\
\text { lapse prevention }\end{array}$ \\
\hline Berndt 2012 & Content of intervention did not involve relapse prevention \\
\hline Bottausci 1995 & Small trial, $<10$ participants per condition \\
\hline Brown 2001 & $\begin{array}{l}\text { Considered for inclusion because comparison of different intensity interventions. Intervention fo- } \\
\text { cus was on use of CBT for treatment of depression. Relapse mentioned only in text }\end{array}$ \\
\hline Carmody 1988 & Only 3 months follow-up reported. No significant differences at this point \\
\hline Carmody 2017 & Wrong comparator as both groups had the same amount of contact \\
\hline Cather 2013 & All participants received the same intervention \\
\hline Cinciripini 2000 & Not possible to distinguish relapse prevention from cessation components \\
\hline
\end{tabular}




\begin{tabular}{|c|c|}
\hline Study & Reason for exclusion \\
\hline Copeland 2006 & Evaluated a weight management programme for preventing relapse; see separate Cochrane review \\
\hline Davis 1995 & Short follow-up \\
\hline DiSantis 2010 & Pilot study with only 1-month follow-up \\
\hline Dooley 1992 & Only 3 months follow-up reported. No significant differences at this point \\
\hline Dubren 1977 & Only 1-month follow-up reported \\
\hline Dunphy 2000 & Only 4 to 8 weeks follow-up after delivery and intervention \\
\hline Elfeddali 2012 & $\begin{array}{l}\text { Participants randomly assigned before quitting, no cessation intervention provided to controls, so } \\
\text { test of an Internet cessation programme. Not relapse prevention }\end{array}$ \\
\hline Evins 2011 & Only 60-day follow-up \\
\hline Feeney 2001 & $\begin{array}{l}\text { Not explicitly described as a relapse prevention intervention, and the control condition had low im- } \\
\text { plementation of the basic cessation programme }\end{array}$ \\
\hline French 2007 & Not randomised \\
\hline French 2018 & Study of incentives \\
\hline
\end{tabular}

\begin{tabular}{ll}
\hline Froelicher 2000 & Described a trial in progress, no intervention results \\
\hline Garvey 2012 & $\begin{array}{l}\text { Considered for inclusion because of front-loading of counselling sessions in one group. No mention } \\
\text { of relapse prevention }\end{array}$
\end{tabular}

\begin{tabular}{ll}
\hline George 2000 & Tested a specialised group therapy intervention for people with schizophrenia compared with a \\
standard programme. Included other components in addition to relapse prevention
\end{tabular}

\begin{tabular}{ll}
\hline Goldstein 1989 & $\begin{array}{l}\text { Considered for inclusion because comparison of different intensity interventions. No mention of re- } \\
\text { lapse prevention }\end{array}$ \\
\hline Gruder 1993 & Not possible to distinguish between relapse prevention and cessation components \\
\hline Hall 1994 & $\begin{array}{l}\text { Considered for inclusion because comparison of different intensity interventions. Primary focus } \\
\text { was on CBT for depression as adjunct to cessation intervention. No mention of relapse prevention }\end{array}$ \\
\hline
\end{tabular}

\begin{tabular}{ll}
\hline Hall 1996 & $\begin{array}{l}\text { Considered for inclusion because comparison of different intensity interventions. Primary focus } \\
\text { was on mood management as adjunct to cessation intervention. No mention of relapse prevention }\end{array}$ \\
\hline Hall 1998 & $\begin{array}{l}\text { Considered for inclusion because comparison of different intensity interventions. No mention of re- } \\
\text { lapse prevention }\end{array}$
\end{tabular}

\begin{tabular}{ll}
\hline Hall 2011 & Considered for inclusion because study evaluated extended therapy. Not relapse prevention \\
\hline Hassandra 2017 & Wrong intervention. Relapse prevention but exercise-based \\
\hline Juliano 2006 & $\begin{array}{l}\text { Previously included study. Excluded from } 2018 \text { update because included relapsed smokers rather } \\
\text { than abstainers }\end{array}$ \\
\hline Klesges 1987 & $\begin{array}{l}\text { Randomisation and analysis by worksite, number of individuals in each treatment condition not } \\
\text { given. A non-significant difference favoured relapse prevention }\end{array}$ \\
\hline
\end{tabular}




\begin{tabular}{|c|c|}
\hline Study & Reason for exclusion \\
\hline Lando 1997 & $\begin{array}{l}\text { Considered for inclusion because comparison of different intensity interventions. No mention of re- } \\
\text { lapse prevention }\end{array}$ \\
\hline Laude 2017 & Not relapse prevention \\
\hline Macleod 2003 & $\begin{array}{l}\text { Considered for inclusion because comparison of different intensity interventions. No mention of re- } \\
\text { lapse prevention }\end{array}$ \\
\hline Miller 1997 & $\begin{array}{l}\text { Hospital intervention included relapse prevention components but excluded because no informa- } \\
\text { tion on smoking status of participants, and intervention similar in other respects to other inpatient } \\
\text { trials. Also compared } 2 \text { intensities of telephone follow-up but these were not described as relapse } \\
\text { prevention }\end{array}$ \\
\hline NCT00218465 & Only 5-week follow-up \\
\hline NCT00621777 & Only 3 months' follow-up \\
\hline NCT01131156 & Only 8-week follow-up \\
\hline NCT02888444 & Only 24-week follow-up \\
\hline NCT02968095 & Only 6-week follow-up \\
\hline NCT03113370 & Only 12 -week follow-up \\
\hline NCT03262662 & Not relapse prevention \\
\hline NCT03690596 & Only 12-week follow-up \\
\hline NCT03930329 & Only 8-week follow-up \\
\hline Phillips 2012 & Only 8-week follow-up \\
\hline Reid 1999 & $\begin{array}{l}\text { Considered for inclusion because comparison of different intensity interventions. No mention of re- } \\
\text { lapse prevention }\end{array}$ \\
\hline Schlam 2016 & Study of extended NRT in smokers: covered in Lindson 2019 \\
\hline Schnoll 2015 & Previously included study. Excluded in 2019 update as extended NRT is covered in Lindson 2019 \\
\hline Snuggs 2012 & Wrong design, all participants received text messages \\
\hline Solomon 2000 & $\begin{array}{l}\text { Considered for inclusion because comparison of different intensity interventions. No mention of re- } \\
\text { lapse prevention }\end{array}$ \\
\hline Storro 2008 & Controlled cohort study of postpartum intervention, not randomised \\
\hline Tonstad 2013 & $\begin{array}{l}\text { Test of vaccine versus placebo. Effect of pharmacotherapy post-quit confounded with pharma- } \\
\text { cotherapy before quitting }\end{array}$ \\
\hline Yoon 2009 & Only 2-week follow-up \\
\hline Zelman 1992 & $\begin{array}{l}\text { Considered for inclusion because comparison of different intensity interventions. No mention of re- } \\
\text { lapse prevention }\end{array}$ \\
\hline
\end{tabular}


CBT = cognitive-behavioural therapy

Characteristics of ongoing studies [ordered by study ID]

\section{ACTRN12617000514303}

\begin{tabular}{ll}
\hline Trial name or title & Real-time video counselling for smoking cessation in regional and remote areas \\
\hline Methods & RCT \\
\hline Participants & Not yet recruiting \\
\hline Interventions & Real-time video counselling via Skype, Face Time or other video communication \\
\hline Outcomes & Self-reported 7-day PPA at 12 months \\
\hline Starting date & $28 / 4 / 17$ \\
\hline Contact information & Flora Tzelepis \\
\hline Notes & $\begin{array}{l}\text { Funding: Cancer Institute New South Wales } \\
\text { Declaration of interests: not reported }\end{array}$ \\
\hline
\end{tabular}

\section{Bock 2014}

\begin{tabular}{ll} 
Trial name or title & $\begin{array}{l}\text { Testing the efficacy of yoga as a complementary therapy for smoking cessation: the } \\
\text { BreathEasy trial }\end{array}$ \\
\hline Methods & RCT \\
\hline Participants & 300 smokers \\
\hline Interventions & Yoga, comparison health and wellness program \\
\hline Outcomes & Prolongued abstinence at 12 months \\
\hline Starting date & September 2012 \\
\hline Contact information & Beth Bock \\
\hline
\end{tabular}

Notes

Brandon 2014

\begin{tabular}{ll}
\hline Trial name or title & Preventing smoking initiation or relapse following basic military training \\
\hline Methods & RCT \\
\hline Participants & $\begin{array}{l}7495 \text { airmen recently completed } 8.5 \text { weeks basic miliary training with involuntary tobacco absti- } \\
\text { nence }\end{array}$ \\
\hline Interventions & $\begin{array}{l}\text { Standard smoking cessation booklet (standard condition), targeted guide (targeted guide condi- } \\
\text { tion), targeted guide plus a brief tailored intervention delivered face-to-face (face-to-face condi- } \\
\text { tion) }\end{array}$
\end{tabular}


Brandon 2014 (Continued)

Outcomes Self-reported continuous and 7-day PPA at 24 months

\begin{tabular}{ll}
\hline Starting date & Jan 2013 \\
\hline Contact information & Thomas Brandon
\end{tabular}

\section{Notes}

\section{Diaz 2016}

\begin{tabular}{ll}
\hline Trial name or title & Surviving smokefree randomised controlled trial \\
\hline Methods & RCT \\
\hline Participants & 414 smoking cancer patients \\
\hline Interventions & $\begin{array}{l}\text { Smoking Relapse Prevention intervention (SRP): brief clinical intervention and Forever Free book- } \\
\text { lets and Surviving SmokeFree DVD, Usual Care (UC): one-time routine assessment of smoking be- } \\
\text { haviour and brief clinical intervention }\end{array}$ \\
\hline Outcomes & Self-reported 7-day PPA at 12 months \\
\hline Starting date & June 2012 \\
\hline Contact information & Diana Diaz \\
\hline Notes & \\
\hline
\end{tabular}

\section{Fallgatter 2015}

\begin{tabular}{ll}
\hline Trial name or title & Non-invasive brain stimulation for nicotine addiction \\
\hline Methods & RCT \\
\hline Participants & 74 smokers \\
\hline Interventions & $\begin{array}{l}\text { 4 sessions of intermittent Theta Burst Stimulation (iTBS) as add-on to cognitive behavioural } \\
\text { therapy, Sham iTBS plus CBT }\end{array}$ \\
\hline Outcomes & Abstinence at 12 months (unclear how assessed) \\
\hline Starting date & Unclear \\
\hline Contact information & A.J. Fallgatter \\
\hline Notes & \\
\hline
\end{tabular}

\section{Garvey 2012a}


Garvey 2012a (Continued)

\begin{tabular}{ll} 
Methods & RCT \\
\hline Participants & Unknown recruitment status \\
\hline Interventions & Brief duration counselling: 3-month duration \\
& Moderate duration counselling: 6-month duration \\
& Extended duration counselling: 12-month duration \\
\hline Outcomes & Abstinence at 1 and 2 years \\
\hline Starting date & February 2008 \\
\hline Contact information & Arthur J. Garvey \\
\hline Notes & No updates since June 2011
\end{tabular}

Giovancarli 2016

\begin{tabular}{ll}
\hline Trial name or title & Virtual reality exposure therapy for relapse prevention \\
\hline Methods & RCT \\
\hline Participants & 120 smokers \\
\hline Interventions & CBT group, CBT with virtual reality exposure therapy \\
\hline Outcomes & CO-verified abstinence at 6 months \\
\hline Starting date & August 2014 \\
\hline Contact information & Laurent Boyer \\
\hline
\end{tabular}

Notes

\section{ISRCTN11111428}

Trial name or title Helping people cope with temptations to smoke to reduce relapse: a factorial randomised controlled trial

\begin{tabular}{ll}
\hline Methods & RCT \\
\hline Participants & 1400 users of Stop Smoking Service, UK \\
\hline Interventions & $\begin{array}{l}\text { Smoking replacement produce plus online support, personalised plan and access to Structured } \\
\text { Planning and Prompting programme, smoking replacement product and text message support, } \\
\text { usual care }\end{array}$
\end{tabular}

Outcomes Validated abstinence at 12 months

Starting date April 2016


ISRCTN11111428 (Continued)

\begin{tabular}{ll} 
Contact information & Anna Phillips \\
\hline Notes & Updated August 2018
\end{tabular}

\section{Meghea 2015}

\begin{tabular}{ll}
\hline Trial name or title & Prevent Relapse In SMoking (PRISM) \\
\hline Methods & RCT \\
\hline Participants & $\begin{array}{l}\text { 250 postpartum women who quit smoking in the six months before pregnancy or no later than the } \\
\text { end of the first pregnancy trimester and remained abstinent (which was biochemically verified) un- } \\
\text { til delivery }\end{array}$ \\
\hline Interventions & $\begin{array}{l}\text { Intervention: up to } 4 \text { postnatal counselling calls for mothers and their partners using motivational } \\
\text { interviewing, usual care }\end{array}$ \\
\hline Outcomes & Maternal abstinence at 6 months postpartum \\
\hline Starting date & December 2013 \\
\hline Contact information & Cristian loan Meghea \\
\hline Notes & Characteristics of sample paper published but not outcome results
\end{tabular}

\section{NCT01162239}

\begin{tabular}{ll}
\hline Trial name or title & Maintaining nonsmoking \\
\hline Methods & Randomised parallel assignment \\
\hline Participants & Unknown recruitment status and intended sample size \\
\hline Interventions & $\begin{array}{l}\text { Extended brief contact, extended health education, extended relapse prevention, extended relapse } \\
\text { prevention plus varenicline }\end{array}$ \\
\hline Outcomes & Smoking status (undefined) at up to 104 weeks following treatment initiation \\
\hline Starting date & May 2010 \\
\hline Contact information & University of California, San Francisco; National Institute on Drug Abuse (NIDA) \\
\hline Notes & No updates since October 2015 \\
\hline
\end{tabular}

\section{NCT01305447}

\begin{tabular}{ll}
\hline Trial name or title & Exercise and smoking \\
\hline Methods & RCT \\
\hline
\end{tabular}


NCT01305447 (Continued)
Participants
413 females

Interventions

Exercise maintenance + relapse prevention, exercise maintenance, relapse prevention

Outcomes

Continuous abstinence at 56 weeks

Starting date

October 2009

Contact information

Harry Prapavessis

Notes

NCT01756885

\begin{tabular}{ll}
\hline Trial name or title & Extended varenicline treatment for smoking among cancer patients \\
\hline Methods & Randomised parallel assignment \\
\hline Participants & 374 cancer patient smokers \\
\hline Interventions & $\begin{array}{l}\text { Standard varenicline treatment: } 12 \text { weeks of active varenicline + } 12 \text { weeks of placebo + smoking } \\
\text { cessation counselling } \\
\text { Extended varenicline treatment: } 24 \text { weeks of active varenicline + smoking cessation counselling }\end{array}$ \\
\hline Outcomes & 7-day PPA at week 52 \\
\hline Starting date & Jan 2013 \\
\hline Contact information & Robert A Schnoll \\
\hline Notes & Updated July 2018 \\
\hline
\end{tabular}

NCT02271919

\begin{tabular}{ll}
\hline Trial name or title & Varenicline and combined Nicotine Replacement Therapy (NRT) for smoking cessation \\
\hline Methods & Randomised cross-over assignment \\
\hline Participants & Ongoing recruitment: 500 smokers \\
\hline Interventions & $\begin{array}{l}\text { Varenicline: varenicline tablets, placebo patches, and placebo lozenges, nicotine patch + nicotine } \\
\text { lozenge group: placebo tablets, nicotine patches, and nicotine lozenges, tablets, patches, lozenges } \\
\text { previously assigned, switch to different active therapy, extra tablet + patch }\end{array}$ \\
\hline Outcomes & 7-day PPA at 12 weeks \\
\hline Starting date & May 2015 \\
\hline Contact information & Paul Cinciripini \\
\hline
\end{tabular}


NCT02271919 (Continued)

Notes Updated June 2018

NCT02327104

\begin{tabular}{ll}
\hline Trial name or title & Effectiveness of mindfulness based relapse prevention for tobacco dependents \\
\hline Methods & RCT \\
\hline Participants & Unknown recruitment status, 60 smokers \\
\hline Interventions & Mindfulness-based relapse prevention, control \\
\hline Outcomes & Abstinence (undefined measure and time point) \\
\hline Starting date & October 2012 \\
\hline Contact information & Ana Regina Noto \\
\hline Notes & Updated May 2015 \\
\hline
\end{tabular}

\section{NCT02823028}

\begin{tabular}{ll}
\hline Trial name or title & Twitter-enabled mobile messaging for smoking relapse prevention (Tweet2Quit) \\
\hline Methods & RCT \\
\hline Participants & 960 smokers intended \\
\hline Interventions & NRT + web guide + Tweet2Quit-coed or Tweet2Quit-women only \\
\hline Outcomes & 7-day PPA at 6 months \\
\hline Starting date & October 2016 \\
\hline Contact information & Connie Pechmann \\
\hline
\end{tabular}

\section{Notes}

\section{NCT03365362}

\begin{tabular}{ll}
\hline Trial name or title & A trial of directly observed and long-term varenicline \\
\hline Methods & RCT \\
\hline Participants & Recruiting: 450 opioid treatment patients intended \\
\hline Interventions & $\begin{array}{l}\text { 1) Behavioural: Directly observed therapy, 2) Varenicline tablet x 24 weeks, 3) Self-administered } \\
\text { therapy, 4) Short-term varenicline tablet for } 12 \text { weeks }\end{array}$ \\
\hline Outcomes & 7-day PPA at 1 year \\
\hline \hline
\end{tabular}


NCT03365362 (Continued)

Starting date

Oct 252018

Contact information

Shadi Nahvi

Notes

NCT03673228

\begin{tabular}{ll}
\hline Trial name or title & Preventing smoking relapse after total joint replacement surgery \\
\hline Methods & RCT \\
\hline Participants & Not yet recruiting, 300 patients after total joint replacement surgery intended \\
\hline Interventions & $\begin{array}{l}\text { Comprehensive relapse prevention intervention, inc visit prior to discharge, } 6 \text { follow-up calls up to } \\
60 \text { days after hospital visit, text message support, caregiver support, NRT }\end{array}$ \\
\hline Outcomes & Self-report PPA at 1 year \\
\hline Starting date & March 2019 \\
\hline Contact information & Scott Sherman \\
\hline
\end{tabular}

Notes

\section{NCT03760224}

\begin{tabular}{ll}
\hline Trial name or title & Effectiveness of WhatsApp online group discussion for smoking relapse prevention \\
\hline Methods & RCT \\
\hline Participants & Recruiting: 1008 intended \\
\hline Interventions & WhatsApp group will allow real-time group discussion for 8 weeks vs text messages \\
\hline Outcomes & 7-day PPA at 1 year \\
\hline Starting date & Oct 42018 \\
\hline Contact information & Derek Cheung \\
\hline
\end{tabular}

Notes

$\mathrm{CBT}=$ cognitive behavioural therapy

$\mathrm{CO}=$ carbon monoxide

$\mathrm{DVD}=$ digital video disc

iTBS = intermittent Theta Burst Stimulation

NIDA = National Institute on Drug Abuse

NRT: nicotine replacement therapy

PPA = point prevalence abstinence

$\mathrm{RCT}=$ randomised controlled trial 
UC = usual care

\section{DATA AND ANALYSES}

Comparison 1. Behavioural interventions for abstinent pregnant/postpartum women

\begin{tabular}{|c|c|c|c|c|}
\hline Outcome or subgroup title & $\begin{array}{l}\text { No. of } \\
\text { studies }\end{array}$ & $\begin{array}{l}\text { No. of } \\
\text { partici- } \\
\text { pants }\end{array}$ & Statistical method & Effect size \\
\hline $\begin{array}{l}1 \text { Not smoking at delivery/last fol- } \\
\text { low-up prior to delivery }\end{array}$ & 8 & 1523 & Risk Ratio (M-H, Random, 95\% Cl) & $1.05[0.99,1.11]$ \\
\hline 1.1 Self-help intervention & 1 & 171 & Risk Ratio (M-H, Random, 95\% Cl) & $1.05[0.91,1.21]$ \\
\hline 1.2 Individual counselling & 5 & 641 & Risk Ratio (M-H, Random, 95\% Cl) & $1.01[0.89,1.13]$ \\
\hline 1.3 Telephone counselling & 2 & 711 & Risk Ratio (M-H, Random, 95\% Cl) & $1.06[0.99,1.15]$ \\
\hline $\begin{array}{l}2 \text { Not smoking at longest follow-up } \\
\text { after delivery }\end{array}$ & 14 & 4606 & Risk Ratio (M-H, Random, 95\% Cl) & $1.02[0.94,1.09]$ \\
\hline 2.1 Intervention during pregnancy & 5 & 690 & Risk Ratio (M-H, Random, 95\% Cl) & $1.00[0.80,1.26]$ \\
\hline $\begin{array}{l}2.2 \text { Intervention initiated during } \\
\text { pregnancy and continued postpar- } \\
\text { tum }\end{array}$ & 6 & 2071 & Risk Ratio (M-H, Random, 95\% Cl) & $0.99[0.90,1.09]$ \\
\hline 2.3 Intervention initiated after birth & 4 & 1845 & Risk Ratio (M-H, Random, 95\% Cl) & $1.06[0.87,1.28]$ \\
\hline
\end{tabular}

Analysis 1.1. Comparison 1 Behavioural interventions for abstinent pregnant/ postpartum women, Outcome 1 Not smoking at delivery/last follow-up prior to delivery.

\begin{tabular}{|c|c|c|c|c|c|}
\hline Study or subgroup & $\begin{array}{c}\text { Treatment } \\
\mathrm{n} / \mathrm{N}\end{array}$ & $\begin{array}{c}\text { Control } \\
n / N\end{array}$ & $\begin{array}{c}\text { Risk Ratio } \\
\text { M-H, Random, 95\% Cl }\end{array}$ & Weight & $\begin{array}{c}\text { Risk Ratio } \\
\text { M-H, Random, } 95 \% \text { CI }\end{array}$ \\
\hline \multicolumn{6}{|c|}{ 1.1.1 Self-help intervention } \\
\hline Ershoff 1995 & $73 / 87$ & $67 / 84$ & $\longrightarrow$ & $16.28 \%$ & $1.05[0.91,1.21]$ \\
\hline Subtotal $(95 \% \mathrm{Cl})$ & 87 & 84 & & $16.28 \%$ & $1.05[0.91,1.21]$ \\
\hline \multicolumn{6}{|c|}{ Total events: 73 (Treatment), 67 (Control) } \\
\hline \multicolumn{6}{|c|}{ Heterogeneity: Not applicable } \\
\hline \multicolumn{6}{|c|}{ Test for overall effect: $Z=0.7(P=0.48)$} \\
\hline \multicolumn{6}{|c|}{ 1.1.2 Individual counselling } \\
\hline Hajek 2001 & $66 / 114$ & $68 / 135$ & & $6.22 \%$ & $1.15[0.91,1.45]$ \\
\hline Lowe 1997 & $32 / 40$ & $29 / 38$ & 1 & $5.9 \%$ & $1.05[0.83,1.33]$ \\
\hline Morasco 2006 & $10 / 14$ & $16 / 19$ & & $2.21 \%$ & $0.85[0.58,1.25]$ \\
\hline Secker-Walker 1995 & $55 / 85$ & $54 / 80$ & & $6.84 \%$ & $0.96[0.77,1.19]$ \\
\hline Subtotal $(95 \% \mathrm{Cl})$ & 308 & 333 & & $23.05 \%$ & $1.01[0.89,1.13]$ \\
\hline \multicolumn{6}{|c|}{ Total events: 185 (Treatment), 196 (Control) } \\
\hline \multicolumn{6}{|c|}{ Heterogeneity: $\mathrm{Tau}^{2}=0 ; \mathrm{Chi}^{2}=3.07, \mathrm{df}=4(\mathrm{P}=0.55) ; \mathrm{I}^{2}=0 \%$} \\
\hline
\end{tabular}




\begin{tabular}{|c|c|c|c|c|c|}
\hline Study or subgroup & $\begin{array}{l}\text { Treatment } \\
\mathrm{n} / \mathrm{N}\end{array}$ & $\begin{array}{c}\text { Control } \\
n / N\end{array}$ & $\begin{array}{c}\text { Risk Ratio } \\
\text { M-H, Random, } 95 \% \mathrm{Cl}\end{array}$ & Weight & $\begin{array}{c}\text { Risk Ratio } \\
\text { M-H, Random, } 95 \% \mathrm{Cl}\end{array}$ \\
\hline \multicolumn{3}{|c|}{ Test for overall effect: $Z=0.12(P=0.91)$} & & & \\
\hline \multicolumn{6}{|c|}{ 1.1.3 Telephone counselling } \\
\hline McBride 1999 & $224 / 258$ & $110 / 137$ & $=$ & $35.75 \%$ & $1.08[0.98,1.19]$ \\
\hline McBride 2004 & $173 / 209$ & $85 / 107$ & & $24.92 \%$ & $1.04[0.93,1.17]$ \\
\hline Subtotal $(95 \% \mathrm{Cl})$ & 467 & 244 & & $60.66 \%$ & $1.06[0.99,1.15]$ \\
\hline \multicolumn{6}{|c|}{ Total events: 397 (Treatment), 195 (Control) } \\
\hline \multicolumn{6}{|c|}{ Heterogeneity: $\operatorname{Tau}^{2}=0 ; \mathrm{Chi}^{2}=0.24, \mathrm{df}=1(\mathrm{P}=0.63) ; \mathrm{I}^{2}=0 \%$} \\
\hline \multicolumn{6}{|c|}{ Test for overall effect: $Z=1.68(P=0.09)$} \\
\hline Total $(95 \% \mathrm{Cl})$ & 862 & 661 & & $100 \%$ & $1.05[0.99,1.11]$ \\
\hline \multicolumn{6}{|c|}{ Total events: 655 (Treatment), 458 (Control) } \\
\hline \multicolumn{6}{|c|}{ Heterogeneity: $\mathrm{Tau}^{2}=0 ; \mathrm{Chi}^{2}=3.96, \mathrm{df}=7(\mathrm{P}=0.78) ; \mathrm{I}^{2}=0 \%$} \\
\hline \multicolumn{6}{|c|}{ Test for overall effect: $\mathrm{Z}=1.65(\mathrm{P}=0.1)$} \\
\hline \multicolumn{6}{|c|}{ Test for subgroup differences: $\mathrm{Chi}^{2}=0.61, \mathrm{df}=1(\mathrm{P}=0.74), \mathrm{I}^{2}=0 \%$} \\
\hline
\end{tabular}

Analysis 1.2. Comparison 1 Behavioural interventions for abstinent pregnant/ postpartum women, Outcome 2 Not smoking at longest follow-up after delivery.

\begin{tabular}{|c|c|c|c|c|c|}
\hline Study or subgroup & $\begin{array}{l}\text { Treatment } \\
\mathrm{n} / \mathrm{N}\end{array}$ & $\begin{array}{c}\text { Control } \\
\mathrm{n} / \mathrm{N}\end{array}$ & $\begin{array}{l}\text { Risk Ratio } \\
\text { M-H, Random, } 95 \% \mathrm{Cl}\end{array}$ & Weight & $\begin{array}{c}\text { Risk Ratio } \\
\text { M-H, Random, } 95 \% \text { CI }\end{array}$ \\
\hline \multicolumn{6}{|c|}{ 1.2.1 Intervention during pregnancy } \\
\hline Hajek 2001 & $26 / 114$ & $34 / 135$ & \begin{tabular}{l|l}
1 & \\
&
\end{tabular} & $2.74 \%$ & $0.91[0.58,1.41]$ \\
\hline McBride 1999 & $66 / 157$ & $33 / 78$ & - & $5.32 \%$ & $0.99[0.72,1.37]$ \\
\hline Morasco 2006 & $6 / 14$ & $6 / 19$ & & $0.68 \%$ & $1.36[0.55,3.33]$ \\
\hline Ruger 2008 & $9 / 24$ & $5 / 33$ & & $0.6 \%$ & $2.48[0.95,6.45]$ \\
\hline Secker-Walker 1998 & $25 / 55$ & $32 / 61$ & & $3.84 \%$ & $0.87[0.6,1.26]$ \\
\hline Subtotal $(95 \% \mathrm{Cl})$ & 364 & 326 & & $13.17 \%$ & $1[0.8,1.26]$ \\
\hline \multicolumn{6}{|c|}{ Total events: 132 (Treatment), 110 (Control) } \\
\hline \multicolumn{6}{|c|}{ Heterogeneity: $\mathrm{Tau}^{2}=0.01 ; \mathrm{Chi}^{2}=4.65, \mathrm{df}=4(\mathrm{P}=0.33) ; \mathrm{I}^{2}=13.92 \%$} \\
\hline \multicolumn{6}{|c|}{ Test for overall effect: $Z=0.02(P=0.98)$} \\
\hline \multicolumn{6}{|c|}{$\begin{array}{l}\text { 1.2.2 Intervention initiated during pregnancy and continued postpar- } \\
\text { tum }\end{array}$} \\
\hline Brandon 2012 & $190 / 343$ & $210 / 357$ & - & $28.66 \%$ & $0.94[0.83,1.07]$ \\
\hline McBride 1999 & $63 / 146$ & $33 / 78$ & 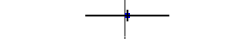 & $5.27 \%$ & $1.02[0.74,1.4]$ \\
\hline McBride 2004 & $105 / 231$ & $47 / 118$ & 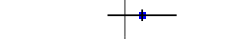 & $7.67 \%$ & $1.14[0.88,1.48]$ \\
\hline Pollak 2016 & $66 / 188$ & $71 / 194$ & - & $7.37 \%$ & $0.96[0.73,1.25]$ \\
\hline Reitzel 2010 & $31 / 136$ & $19 / 115$ & & $2.06 \%$ & $1.38[0.82,2.31]$ \\
\hline Secker-Walker 1995 & $28 / 85$ & $26 / 80$ & & $2.83 \%$ & $1.01[0.65,1.57]$ \\
\hline Subtotal $(95 \% \mathrm{Cl})$ & 1129 & 942 & & $53.87 \%$ & $0.99[0.9,1.09]$ \\
\hline \multicolumn{6}{|c|}{ Total events: 483 (Treatment), 406 (Control) } \\
\hline \multicolumn{6}{|c|}{ Heterogeneity: $\operatorname{Tau}^{2}=0 ; \mathrm{Chi}^{2}=3.49, \mathrm{df}=5(\mathrm{P}=0.63) ; \mathrm{I}^{2}=0 \%$} \\
\hline \multicolumn{6}{|c|}{ Test for overall effect: $\mathrm{Z}=0.15(\mathrm{P}=0.88)$} \\
\hline \multicolumn{6}{|c|}{ 1.2.3 Intervention initiated after birth } \\
\hline Hannöver 2009 & $34 / 148$ & $39 / 156$ & + & $3.37 \%$ & $0.92[0.62,1.37]$ \\
\hline
\end{tabular}




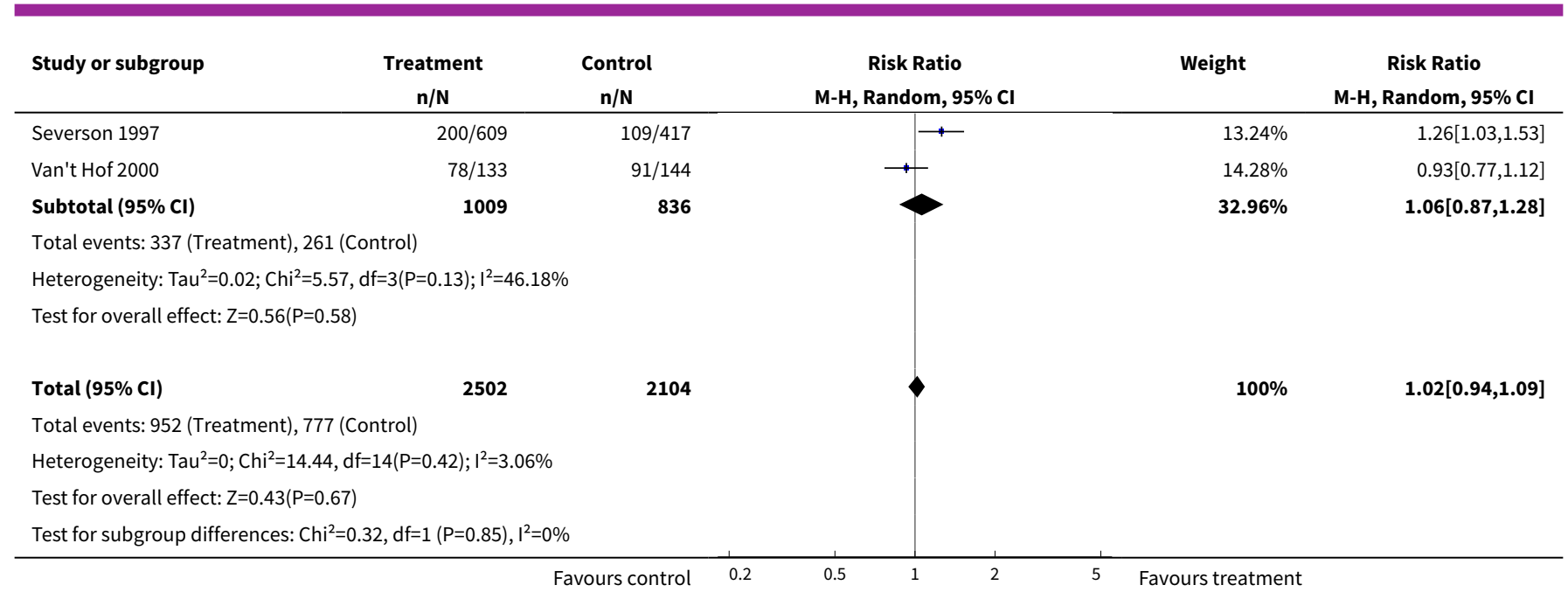

\section{Comparison 2. Interventions for abstinent hospitalised smokers}

\begin{tabular}{llllll}
\hline Outcome or subgroup title & $\begin{array}{l}\text { No. of } \\
\text { studies }\end{array}$ & $\begin{array}{l}\text { No. of } \\
\text { partici- } \\
\text { pants }\end{array}$ & Statistical method & Effect size \\
\hline $\begin{array}{l}1 \text { Behavioural interventions, cessation at longest } \\
\text { follow-up }\end{array}$ & 5 & 1385 & $\begin{array}{l}\text { Risk Ratio (M-H, Random, 95\% } \\
\mathrm{Cl})\end{array}$ & $1.10[0.82,1.47]$ \\
\hline $\begin{array}{l}2 \text { Pharmacotherapy interventions, cessation at } \\
\text { longest follow-up }\end{array}$ & 2 & 1078 & Risk Ratio (M-H, Fixed, 95\% Cl) & $1.23[0.94,1.60]$ \\
\hline
\end{tabular}

Analysis 2.1. Comparison 2 Interventions for abstinent hospitalised smokers, Outcome 1 Behavioural interventions, cessation at longest follow-up.

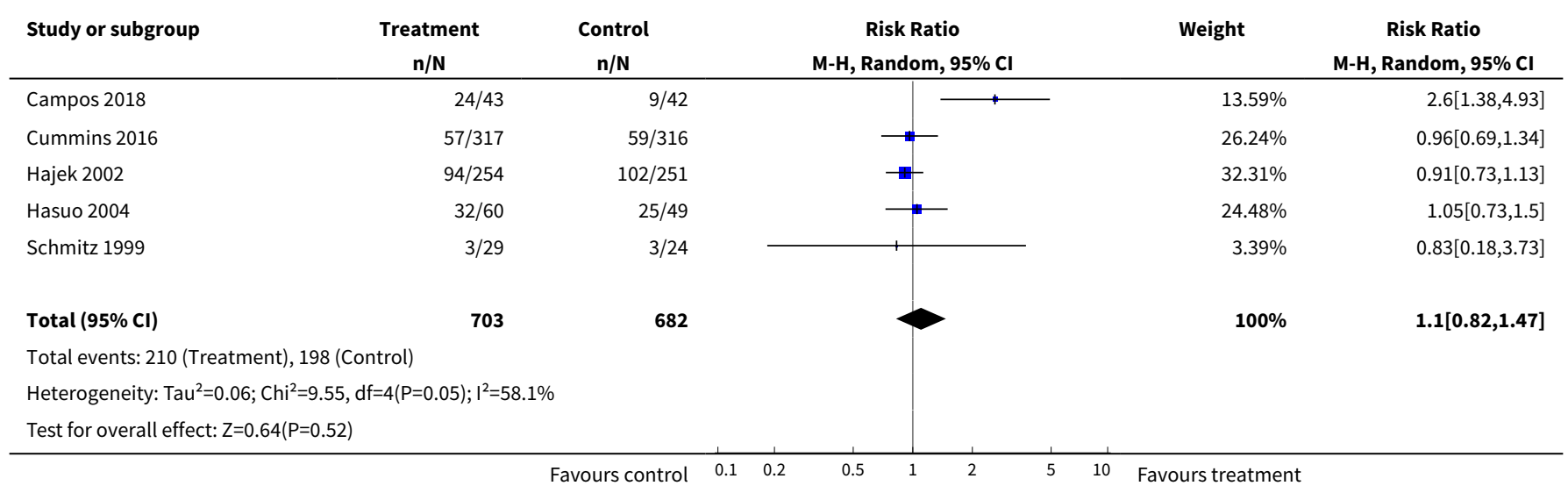


Analysis 2.2. Comparison 2 Interventions for abstinent hospitalised smokers, Outcome 2 Pharmacotherapy interventions, cessation at longest follow-up.

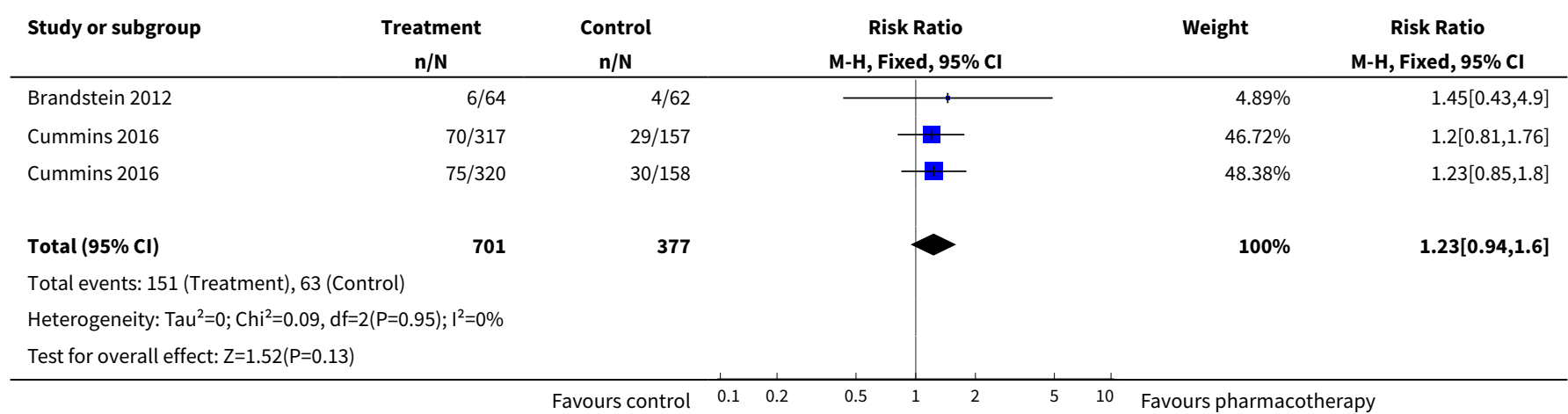

\section{Comparison 3. Behavioural interventions for unaided abstainers}

\begin{tabular}{lllll}
\hline Outcome or subgroup title & $\begin{array}{l}\text { No. of } \\
\text { studies }\end{array}$ & $\begin{array}{l}\text { No. of par- } \\
\text { ticipants }\end{array}$ & Statistical method & Effect size \\
\hline 1 Cessation at longest follow-up & 5 & 3561 & Risk Ratio (M-H, Random, 95\% Cl) & $1.06[0.96,1.16]$ \\
\hline 1.1 Low-intensity interventions & 5 & 3561 & Risk Ratio (M-H, Random, 95\% Cl) & $1.06[0.96,1.16]$ \\
\hline
\end{tabular}

Analysis 3.1. Comparison 3 Behavioural interventions for unaided abstainers, Outcome 1 Cessation at longest follow-up.

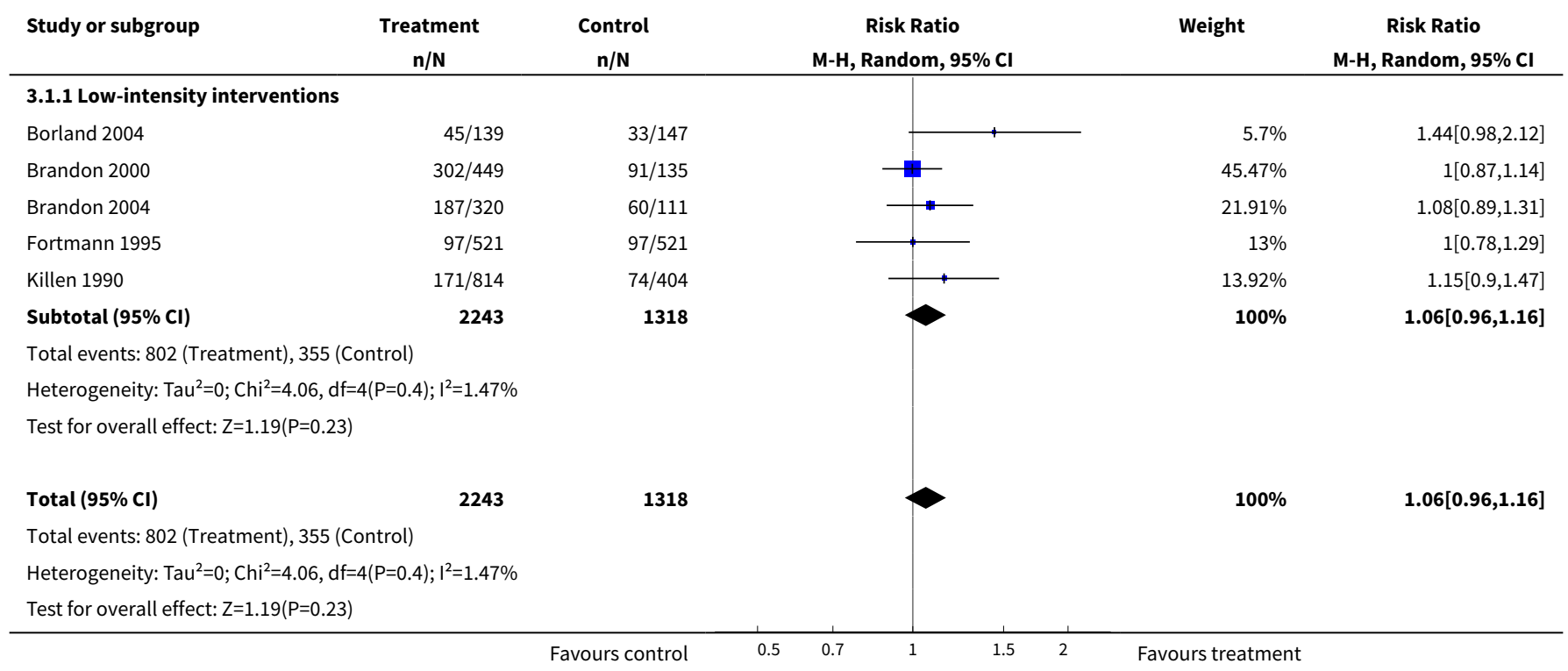


Comparison 4. Behavioural interventions for assisted abstainers

\begin{tabular}{llllll}
\hline Outcome or subgroup title & $\begin{array}{l}\text { No. of } \\
\text { studies }\end{array}$ & $\begin{array}{l}\text { No. of } \\
\text { partici- } \\
\text { pants }\end{array}$ & Statistical method & Effect size \\
\hline 1 Cessation at longest follow-up & 11 & 5523 & Risk Ratio (M-H, Random, 95\% Cl) & $0.98[0.87,1.11]$ \\
\hline 1.1 Low-intensity interventions & 7 & 4402 & Risk Ratio (M-H, Random, 95\% Cl) & $0.95[0.82,1.09]$ \\
\hline 1.2 High-intensity interventions & 4 & 1121 & Risk Ratio (M-H, Random, 95\% Cl) & $1.06[0.82,1.36]$ \\
\hline
\end{tabular}

Analysis 4.1. Comparison 4 Behavioural interventions for assisted abstainers, Outcome 1 Cessation at longest follow-up.

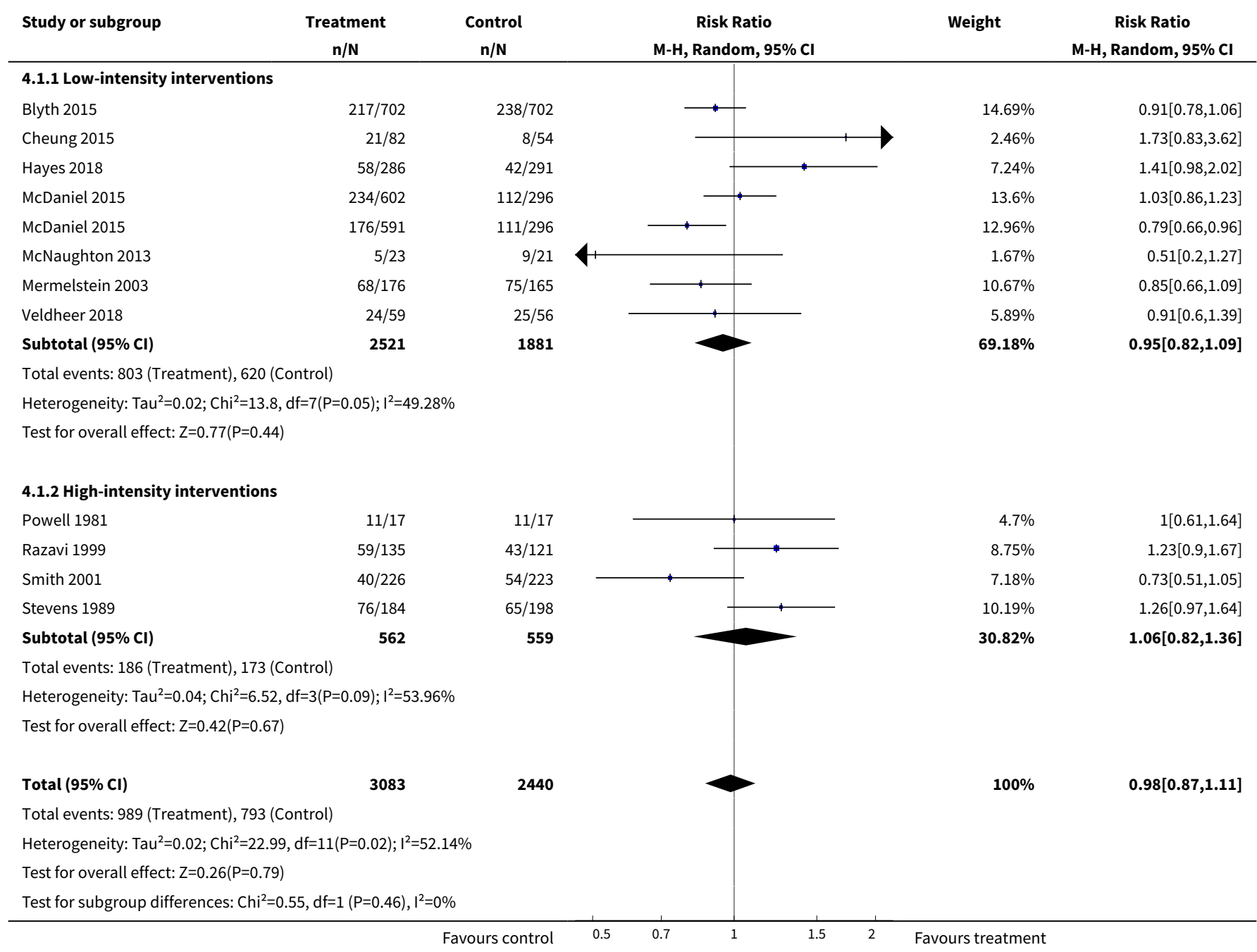


Comparison 5. Pharmacotherapy for assisted abstainers

\begin{tabular}{|c|c|c|c|c|}
\hline Outcome or subgroup title & $\begin{array}{l}\text { No. of } \\
\text { studies }\end{array}$ & $\begin{array}{l}\text { No. of } \\
\text { partici- } \\
\text { pants }\end{array}$ & Statistical method & Effect size \\
\hline $\begin{array}{l}1 \text { Nicotine replacement therapy versus } \\
\text { placebo. Cessation } 12 \text { months + after quit } \\
\text { date }\end{array}$ & 2 & 553 & Risk Ratio (M-H, Fixed, 95\% Cl) & $1.04[0.77,1.40]$ \\
\hline 1.116-week nicotine gum vs placebo & 1 & 143 & Risk Ratio (M-H, Fixed, 95\% Cl) & $1.44[0.77,2.69]$ \\
\hline $\begin{array}{l}1.216 \text {-week nicotine gum + bupropion vs } \\
\text { placebo gum + bupropion }\end{array}$ & 1 & 146 & Risk Ratio (M-H, Fixed, 95\% Cl) & $0.96[0.59,1.56]$ \\
\hline 1.39-month nicotine inhaler vs placebo & 1 & 168 & Risk Ratio (M-H, Fixed, 95\% Cl) & $0.96[0.54,1.72]$ \\
\hline $\begin{array}{l}\text { 1.4 9-month nicotine inhaler + bupropion vs } \\
\text { placebo inhaler + bupropion }\end{array}$ & 1 & 96 & Risk Ratio (M-H, Fixed, 95\% Cl) & $0.86[0.39,1.93]$ \\
\hline $\begin{array}{l}2 \text { Bupropion vs placebo. Cessation } 12 \\
\text { months + after quit date }\end{array}$ & 6 & 1697 & Risk Ratio (M-H, Fixed, 95\% Cl) & $1.15[0.98,1.35]$ \\
\hline 2.152 weeks bupropion vs placebo & 1 & 110 & Risk Ratio (M-H, Fixed, 95\% Cl) & $0.96[0.60,1.55]$ \\
\hline 2.245 weeks bupropion vs placebo & 1 & 429 & Risk Ratio (M-H, Fixed, 95\% Cl) & $1.11[0.82,1.51]$ \\
\hline 2.324 weeks bupropion vs placebo & 1 & 176 & Risk Ratio (M-H, Fixed, 95\% Cl) & $1.46[0.77,2.77]$ \\
\hline 2.416 weeks bupropion vs placebo & 1 & 144 & Risk Ratio (M-H, Fixed, 95\% Cl) & $1.72[0.95,3.12]$ \\
\hline $\begin{array}{l}2.516 \text { weeks bupropion + nicotine gum vs } \\
\text { placebo + nicotine gum }\end{array}$ & 1 & 145 & Risk Ratio (M-H, Fixed, 95\% Cl) & $1.14[0.68,1.92]$ \\
\hline 2.69 months bupropion vs placebo & 1 & 141 & Risk Ratio (M-H, Fixed, 95\% Cl) & $1.09[0.64,1.84]$ \\
\hline $\begin{array}{l}2.79 \text { months bupropion + placebo inhaler vs } \\
\text { double placebo }\end{array}$ & 1 & 97 & Risk Ratio (M-H, Fixed, 95\% Cl) & $0.82[0.40,1.68]$ \\
\hline $\begin{array}{l}2.89 \text { months bupropion }+ \text { nicotine inhaler vs } \\
\text { placebo + nicotine inhaler }\end{array}$ & 1 & 93 & Risk Ratio (M-H, Fixed, 95\% Cl) & $1.01[0.43,2.39]$ \\
\hline 2.914 weeks bupropion vs placebo & 1 & 362 & Risk Ratio (M-H, Fixed, 95\% Cl) & $1.19[0.84,1.68]$ \\
\hline $\begin{array}{l}3 \text { Combination NRT \& bupropion vs placebo. } \\
\text { Cessation at longest follow-up }\end{array}$ & 2 & 243 & Risk Ratio (M-H, Fixed, 95\% Cl) & $1.18[0.75,1.87]$ \\
\hline $\begin{array}{l}4 \text { Varenicline vs placebo. Cessation } 12 \\
\text { months + after quit date }\end{array}$ & 2 & 1297 & Risk Ratio (M-H, Fixed, 95\% Cl) & $1.23[1.08,1.41]$ \\
\hline $\begin{array}{l}5 \text { Rimonabant vs placebo. Cessation } 12 \\
\text { months + after quit date }\end{array}$ & 1 & & Risk Ratio (M-H, Fixed, 95\% Cl) & $\begin{array}{l}\text { Totals not select- } \\
\text { ed }\end{array}$ \\
\hline
\end{tabular}


Analysis 5.1. Comparison 5 Pharmacotherapy for assisted abstainers, Outcome 1 Nicotine replacement therapy versus placebo. Cessation 12 months + after quit date.

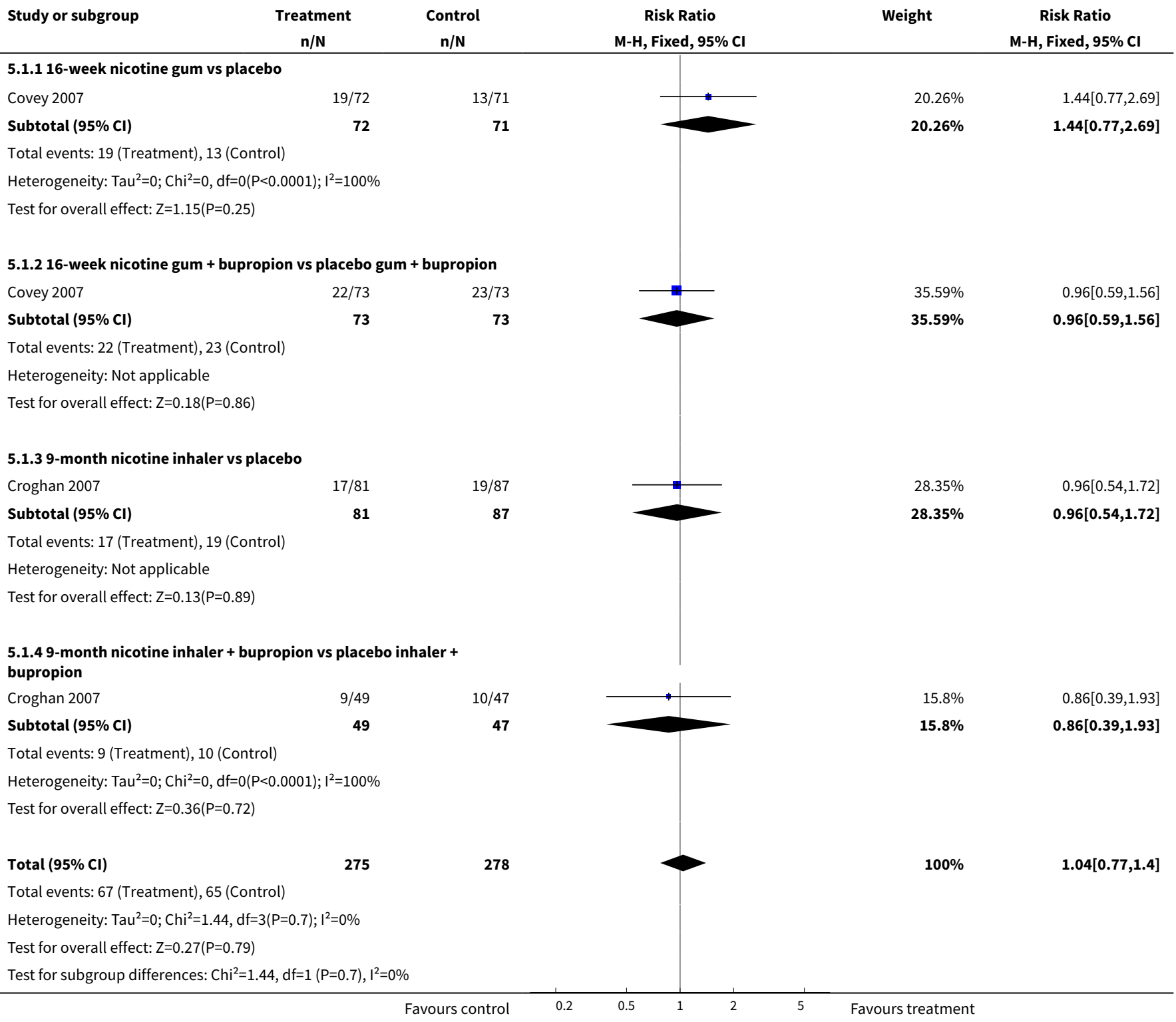

Analysis 5.2. Comparison 5 Pharmacotherapy for assisted abstainers, Outcome 2 Bupropion vs placebo. Cessation 12 months + after quit date.

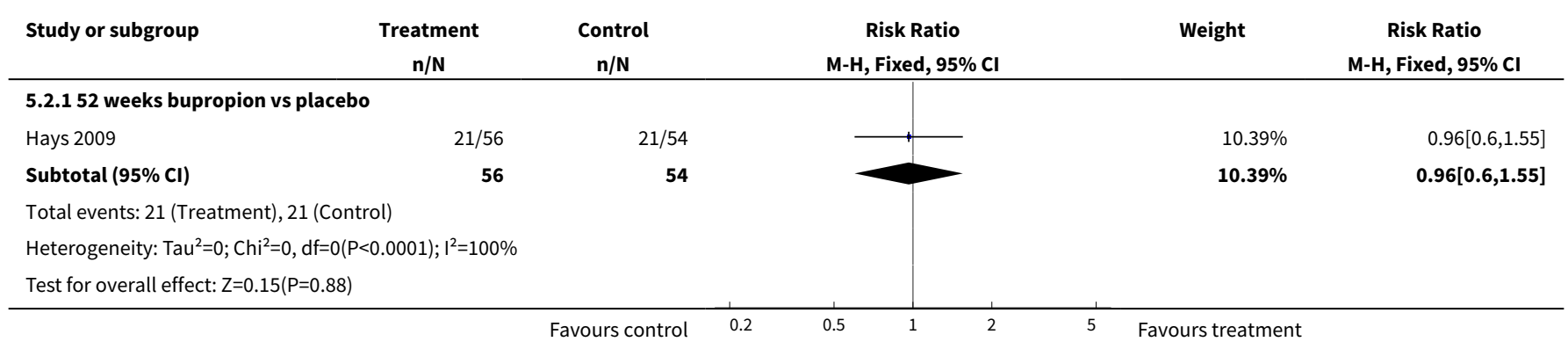




\section{Study or subgroup
$\mathbf{5 . 2 . 2} 45$ weeks bupropion vs placebo}

\section{Hays 2001}

$62 / 214 \quad 56 / 215$

Subtotal $(95 \% \mathrm{Cl})$

214

215

Total events: 62 (Treatment), 56 (Control)

Heterogeneity: Not applicable

Test for overall effect: $Z=0.68(P=0.5)$

\subsubsection{4 weeks bupropion vs placebo}

Hurt 2003

Subtotal $(95 \% \mathrm{Cl})$

Total events: 19 (Treatment), 13 (Control)

Heterogeneity: Not applicable

Test for overall effect: $\mathrm{Z}=1.16(\mathrm{P}=0.25)$

\subsubsection{6 weeks bupropion vs placebo}

Covey 2007

Subtotal $(95 \% \mathrm{Cl})$

$23 / 73$

$13 / 71$

71

Total events: 23 (Treatment), 13 (Control)

Heterogeneity: Not applicable

Test for overall effect: $\mathrm{Z}=1.78(\mathrm{P}=0.07)$
5.2.5 16 weeks bupropion + nicotine gum vs placebo + nicotine gum

Covey 2007

$19 / 72$

Subtotal $(95 \% \mathrm{Cl})$

73

72

Total events: 22 (Treatment), 19 (Control)

Heterogeneity: Not applicable

Test for overall effect: $Z=0.5(P=0.62)$

5.2.6 9 months bupropion vs placebo

Croghan 2007

$21 / 71$

$19 / 70$

Subtotal $(95 \% \mathrm{CI})$

71

70

Total events: 21 (Treatment), 19 (Control)

Heterogeneity: Not applicable

Test for overall effect: $\mathrm{Z}=0.32(\mathrm{P}=0.75)$

5.2.7 9 months bupropion + placebo inhaler vs double placebo

Croghan 2007

$10 / 47$

47

$13 / 50$

Subtotal $(95 \% \mathrm{Cl})$

50

Total events: 10 (Treatment), 13 (Control)

Heterogeneity: Not applicable

Test for overall effect: $Z=0.54(P=0.59)$

5.2.8 9 months bupropion + nicotine inhaler vs placebo + nicotine inhaler

Subtotal $(95 \% \mathrm{Cl})$

$9 / 49$

49

$8 / 44$

44
Croghan 2007
Risk Ratio

M-H, Fixed, $95 \% \mathrm{Cl}$
Risk Ratio

M-H, Fixed, $95 \% \mathrm{Cl}$
Total events: 9 (Treatment), 8 (Control)

Heterogeneity: Not applicable

Test for overall effect: $\mathrm{Z}=0.02$ ( $\mathrm{P}=0.98$ )

5.2.9 14 weeks bupropion vs placebo
$1.11[0.82,1.51]$

27.16\%

$1.11[0.82,1.51]$
$6.32 \%$

$6.32 \%$

$6.41 \%$

$6.41 \%$

$9.3 \%$

$9.3 \%$

$9.3 \%$

$9.3 \%$

$6.12 \%$

$0.82[0.4,1.68]$

$6.12 \%$

$\mathbf{0 . 8 2}[0.4,1.68]$
$1.46[0.77,2.77]$

$1.46[0.77,2.77]$
$1.72[0.95,3.12]$

$1.72[0.95,3.12]$
$1.14[0.68,1.92]$ 


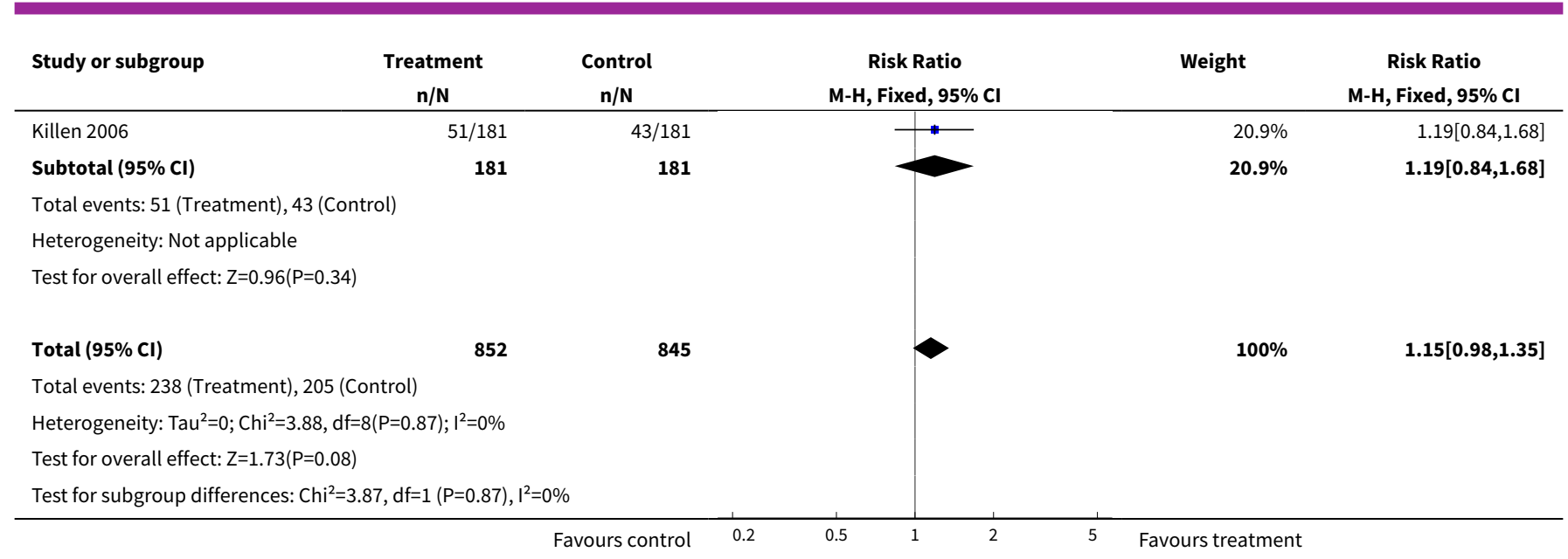

Analysis 5.3. Comparison 5 Pharmacotherapy for assisted abstainers, Outcome 3 Combination NRT \& bupropion vs placebo. Cessation at longest follow-up.

\begin{tabular}{|c|c|c|c|c|c|}
\hline Study or subgroup & $\begin{array}{c}\text { Treatment } \\
\mathrm{n} / \mathrm{N}\end{array}$ & $\begin{array}{c}\text { Control } \\
n / N\end{array}$ & $\begin{array}{c}\text { Risk Ratio } \\
\text { M-H, Fixed, 95\% Cl }\end{array}$ & Weight & $\begin{array}{c}\text { Risk Ratio } \\
\text { M-H, Fixed, } 95 \% \mathrm{Cl}\end{array}$ \\
\hline Covey 2007 & $22 / 73$ & $13 / 71$ & $\rightarrow$ & $50.6 \%$ & $1.65[0.9,3.01]$ \\
\hline Croghan 2007 & $9 / 49$ & $13 / 50$ & - & $49.4 \%$ & $0.71[0.33,1.5]$ \\
\hline Total $(95 \% \mathrm{Cl})$ & 122 & 121 & & $100 \%$ & $1.18[0.75,1.87]$ \\
\hline \multicolumn{6}{|c|}{ Total events: 31 (Treatment), 26 (Control) } \\
\hline \multicolumn{6}{|c|}{ Heterogeneity: $\mathrm{Tau}^{2}=0 ; \mathrm{Chi}^{2}=2.95, \mathrm{df}=1(\mathrm{P}=0.09) ; \mathrm{I}^{2}=66.14 \%$} \\
\hline \multicolumn{6}{|c|}{ Test for overall effect: $Z=0.71(P=0.48)$} \\
\hline
\end{tabular}

Analysis 5.4. Comparison 5 Pharmacotherapy for assisted abstainers, Outcome 4 Varenicline vs placebo. Cessation 12 months + after quit date.

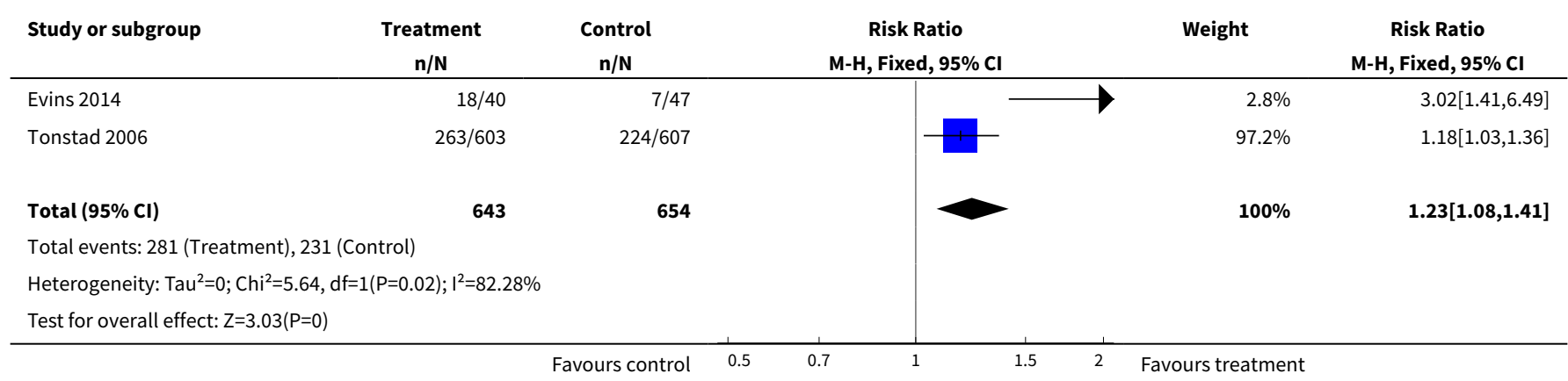


Analysis 5.5. Comparison 5 Pharmacotherapy for assisted abstainers, Outcome 5 Rimonabant vs placebo. Cessation 12 months + after quit date.

\begin{tabular}{|c|c|c|c|c|c|c|}
\hline \multirow{2}{*}{$\begin{array}{l}\text { Study or subgroup } \\
\text { STRATUS-WW } 2006\end{array}$} & $\begin{array}{c}\text { Treatment } \\
\mathrm{n} / \mathrm{N}\end{array}$ & $\begin{array}{c}\text { Control } \\
\mathrm{n} / \mathrm{N}\end{array}$ & & \multicolumn{2}{|c|}{$\begin{array}{c}\text { Risk Ratio } \\
\text { M-H, Fixed, 95\% Cl }\end{array}$} & \multirow{2}{*}{$\begin{array}{c}\text { Risk Ratio } \\
\text { M-H, Fixed, 95\% Cl } \\
1.29[1.08,1.55]\end{array}$} \\
\hline & $281 / 675$ & $110 / 342$ & & & 1 & \\
\hline
\end{tabular}

\section{Comparison 6. Pharmacotherapy for unaided abstainers}

\begin{tabular}{llllll}
\hline Outcome or subgroup title & $\begin{array}{l}\text { No. of } \\
\text { studies }\end{array}$ & $\begin{array}{l}\text { No. of } \\
\text { partici- } \\
\text { pants }\end{array}$ & Statistical method & Effect size \\
\hline 1 Cessation 12 months after quit date & 2 & 2261 & Risk Ratio (M-H, Fixed, 95\% Cl) & $1.24[1.04,1.47]$ \\
\hline $\begin{array}{l}1.1 \text { Nicotine gum vs placebo after brief unas- } \\
\text { sisted abstinence }\end{array}$ & 2 & 2261 & Risk Ratio (M-H, Fixed, 95\% Cl) & $1.24[1.04,1.47]$ \\
\hline
\end{tabular}

Analysis 6.1. Comparison 6 Pharmacotherapy for unaided abstainers, Outcome 1 Cessation 12 months after quit date.

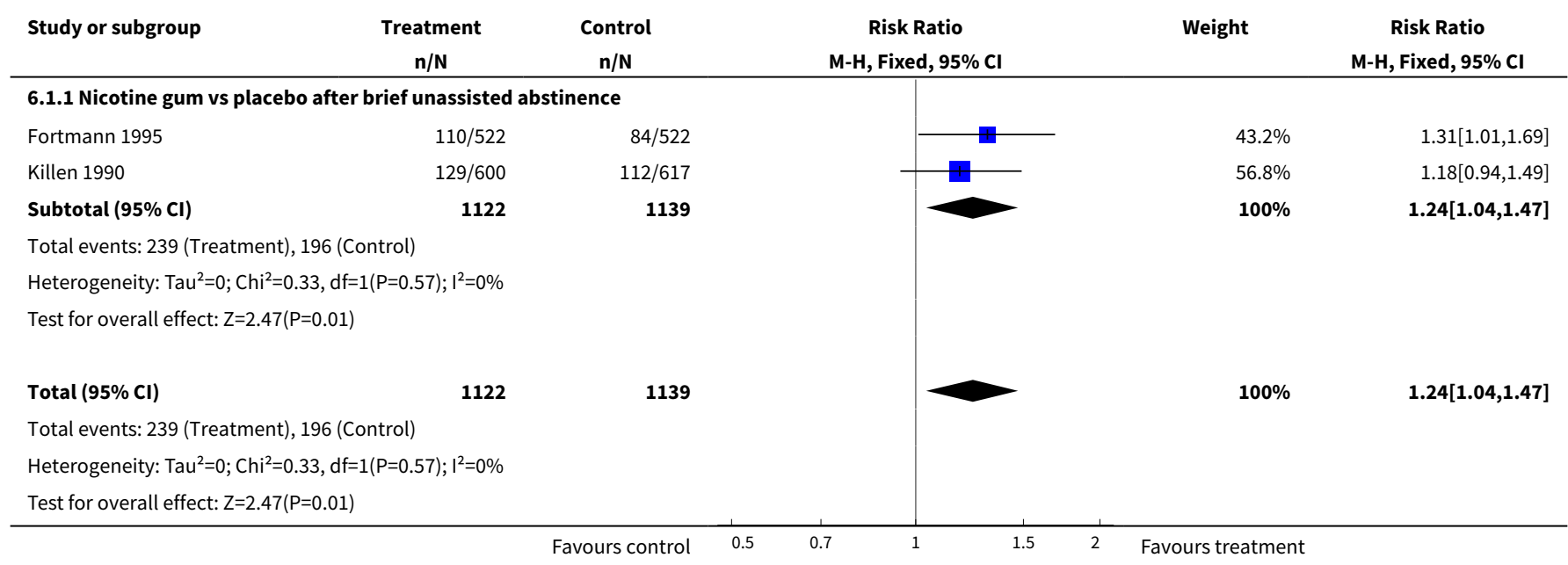

Comparison 7. Behavioural interventions for smokers. RP vs cessation, matched for programme length

\begin{tabular}{lllll}
\hline Outcome or subgroup title & $\begin{array}{l}\text { No. of } \\
\text { studies }\end{array}$ & $\begin{array}{l}\text { No. of } \\
\text { partici- } \\
\text { pants }\end{array}$ & Statistical method & Effect size \\
\hline $\begin{array}{l}\text { 1 Group or individual format therapy (+/- adjunct phar- } \\
\text { macotherapy), cessation at longest follow-up }\end{array}$ & 10 & 872 & $\begin{array}{l}\text { Risk Ratio (M-H, Random, } \\
95 \% \mathrm{Cl})\end{array}$ & $\begin{array}{l}0.92[0.72, \\
1.16]\end{array}$ \\
\hline $\begin{array}{l}\text { 2 Self-help format, cessation at longest follow-up } \\
\text { nisk Ratio (M-H, Random, }\end{array}$ & 1 & 91 & $95 \% \mathrm{Cl})$ & $3.52[0.67$, \\
\hline
\end{tabular}


Analysis 7.1. Comparison 7 Behavioural interventions for smokers. RP vs cessation, matched for programme length, Outcome 1 Group or individual format therapy (+/-adjunct pharmacotherapy), cessation at longest follow-up.

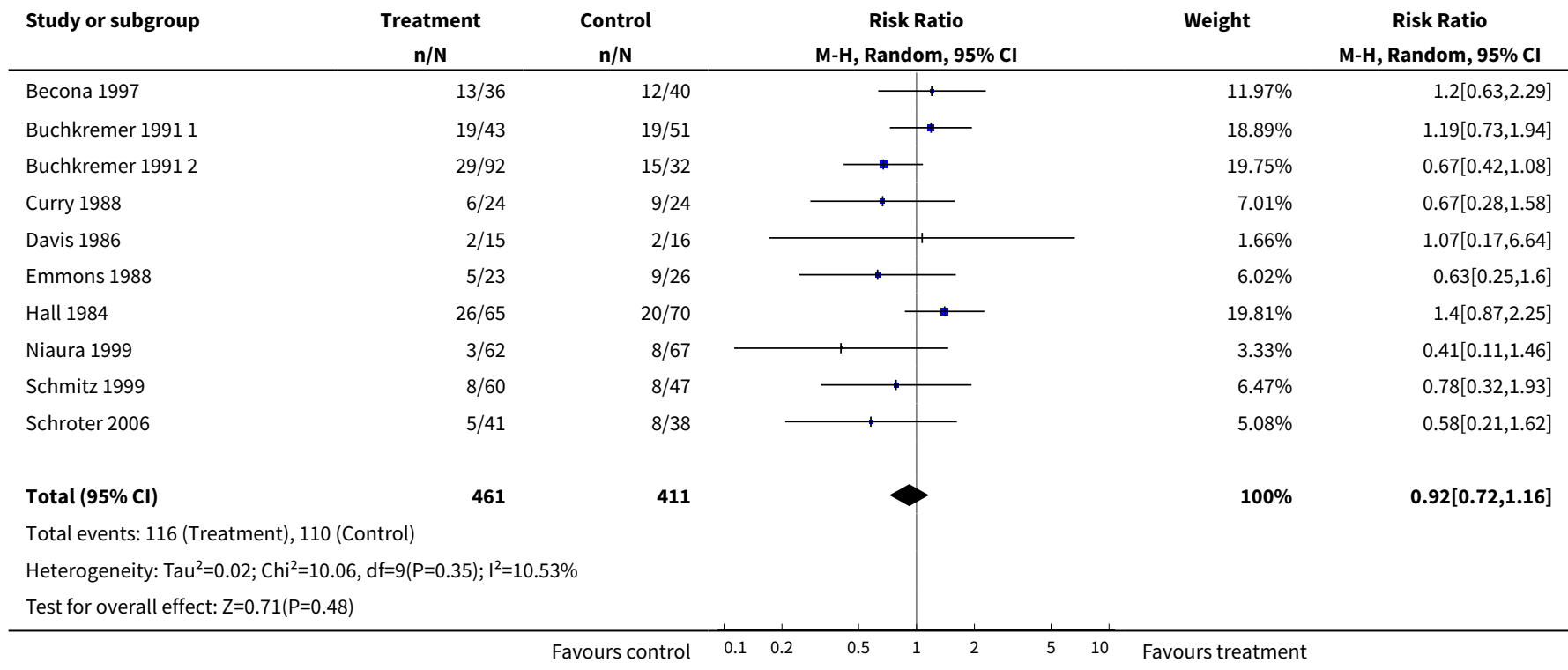

Analysis 7.2. Comparison 7 Behavioural interventions for smokers. RP vs cessation, matched for programme length, Outcome 2 Self-help format, cessation at longest follow-up.

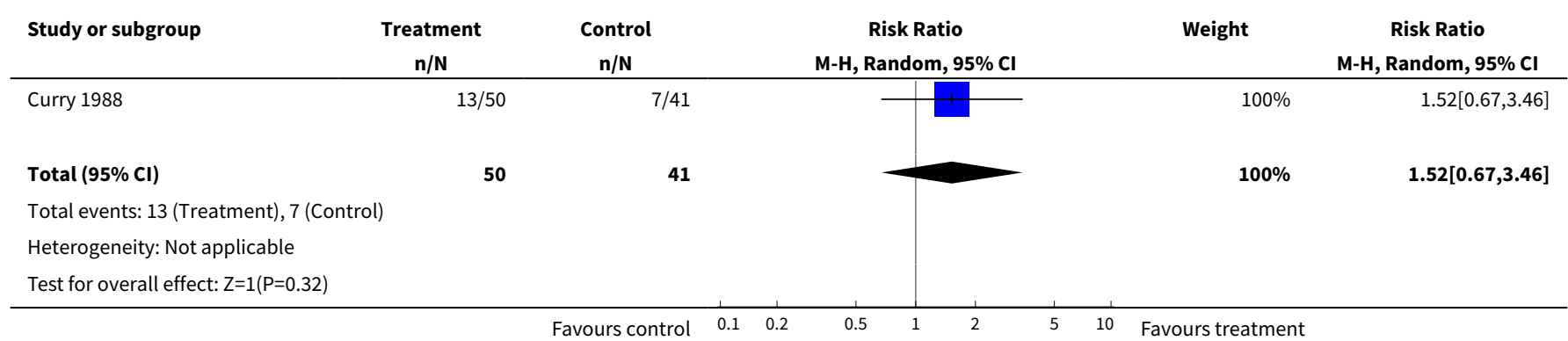

Comparison 8. Behavioural interventions for smokers. RP vs cessation, different intensity programmes

\begin{tabular}{lllll}
\hline Outcome or subgroup title & $\begin{array}{l}\text { No. of } \\
\text { studies }\end{array}$ & $\begin{array}{l}\text { No. of } \\
\text { partici- } \\
\text { pants }\end{array}$ & Statistical method & Effect size \\
\hline 1 Cessation at longest follow-up & 7 & 699 & Risk Ratio (M-H, Random, 95\% Cl) & $1.02[0.80,1.29]$ \\
\hline $\begin{array}{l}1.1 \text { More than four sessions for control } \\
\text { group }\end{array}$ & 5 & 546 & Risk Ratio (M-H, Random, 95\% Cl) & $0.95[0.68,1.33]$ \\
\hline $\begin{array}{l}1.2 \text { Four sessions or less for control } \\
\text { group }\end{array}$ & 2 & 153 & Risk Ratio (M-H, Random, 95\% Cl) & $1.22[0.81,1.86]$ \\
\hline
\end{tabular}


Analysis 8.1. Comparison 8 Behavioural interventions for smokers. RP vs cessation, different intensity programmes, Outcome 1 Cessation at longest follow-up.

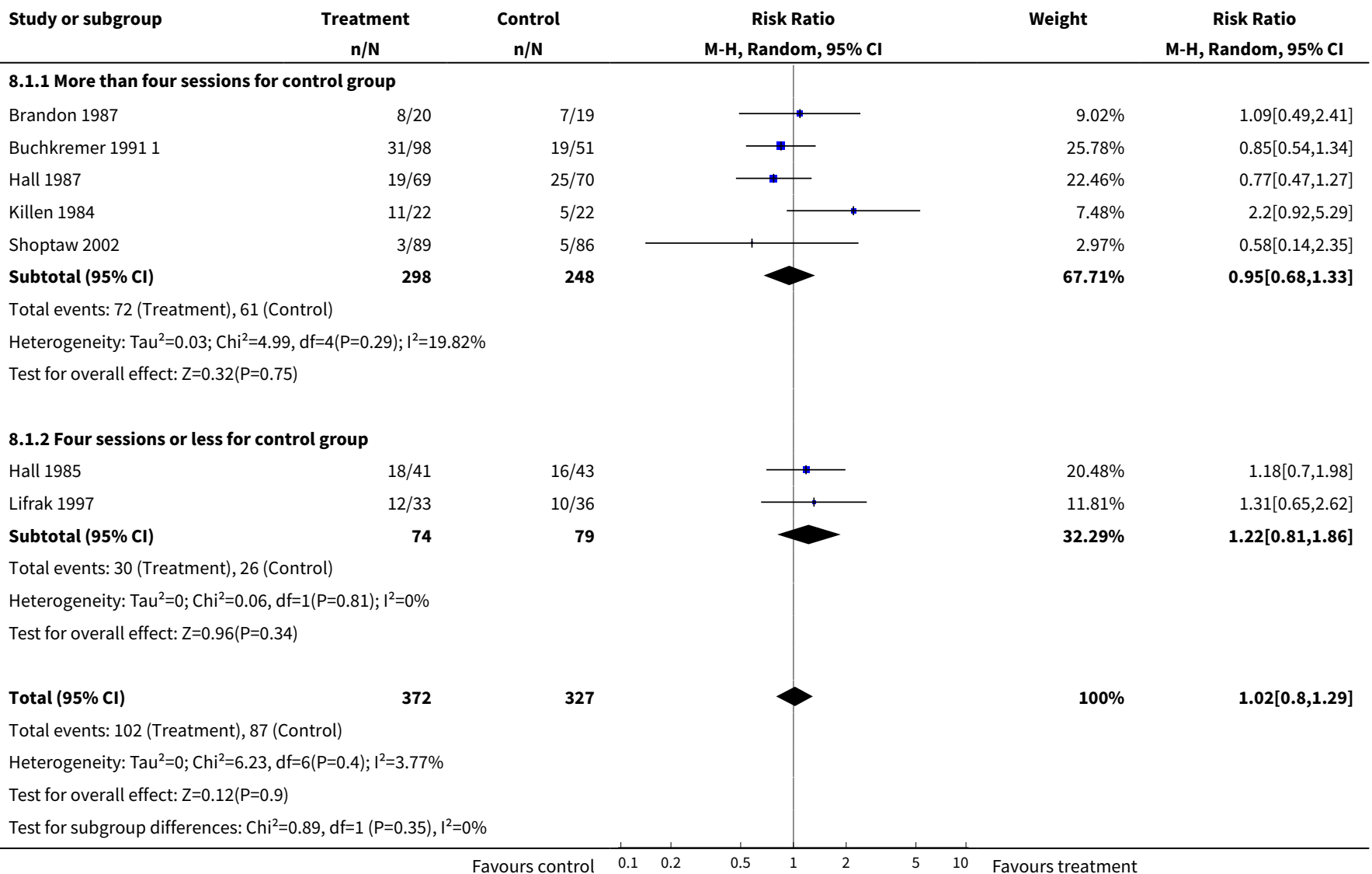

Comparison 9. Interventions for smokers, tests of adjuncts to cessation programmes

\begin{tabular}{|c|c|c|c|c|}
\hline Outcome or subgroup title & $\begin{array}{l}\text { No. of } \\
\text { studies }\end{array}$ & $\begin{array}{l}\text { No. of } \\
\text { partici- } \\
\text { pants }\end{array}$ & Statistical method & Effect size \\
\hline $\begin{array}{l}1 \text { Behavioural interventions, cessation at } \\
\text { longest follow-up }\end{array}$ & 11 & & Risk Ratio (M-H, Random, 95\% Cl) & Subtotals only \\
\hline 1.1 Additional proactive telephone contact & 3 & 2758 & Risk Ratio (M-H, Random, 95\% Cl) & $1.18[0.93,1.49]$ \\
\hline 1.2 Additional print-based support & 3 & 6224 & Risk Ratio (M-H, Random, 95\% Cl) & $1.16[1.01,1.33]$ \\
\hline $\begin{array}{l}1.3 \text { Additional intervention delivered by } \\
\text { computer or mobile phone }\end{array}$ & 4 & 729 & Risk Ratio (M-H, Random, 95\% Cl) & $1.19[0.85,1.66]$ \\
\hline 1.4 Formulation of coping strategies & 1 & 1566 & Risk Ratio (M-H, Random, 95\% Cl) & $1.27[0.97,1.67]$ \\
\hline $\begin{array}{l}2 \text { Combined behavioural and pharma inter- } \\
\text { ventions, cessation at longest follow-up }\end{array}$ & 1 & & Risk Ratio (M-H, Fixed, 95\% Cl) & $\begin{array}{l}\text { Totals not select- } \\
\text { ed }\end{array}$ \\
\hline
\end{tabular}




\begin{tabular}{lllll}
\hline Outcome or subgroup title & $\begin{array}{l}\text { No. of } \\
\text { studies }\end{array}$ & $\begin{array}{l}\text { No. of } \\
\text { partici- } \\
\text { pants }\end{array}$ & Statistical method & Effect size \\
\hline $\begin{array}{l}\text { 2.1 Additional proactive telephone coun- } \\
\text { selling + NRT }\end{array}$ & 1 & Risk Ratio (M-H, Fixed, 95\% Cl) & $0.0[0.0,0.0]$ \\
\hline
\end{tabular}

\section{Analysis 9.1. Comparison 9 Interventions for smokers, tests of adjuncts to cessation programmes, Outcome 1 Behavioural interventions, cessation at longest follow-up.}

\begin{tabular}{lrr} 
Study or subgroup & $\begin{array}{c}\text { Treatment } \\
\mathbf{n} / \mathbf{N}\end{array}$ & \multicolumn{1}{c}{$\begin{array}{c}\text { Control } \\
\mathbf{n} / \mathbf{N}\end{array}$} \\
\hline 9.1.1 Additional proactive telephone contact & \\
Segan 2011 & $67 / 710$ & $68 / 734$ \\
Blebil 2014 & $86 / 120$ & $54 / 111$ \\
Lando 1996 & $177 / 542$ & $165 / 541$ \\
Subtotal (95\% Cl) & $\mathbf{1 3 7 2}$ & $\mathbf{1 3 8 6}$
\end{tabular}

Total events: 330 (Treatment), 287 (Control)

Heterogeneity: $\operatorname{Tau}^{2}=0.03 ; \mathrm{Chi}^{2}=6.14, \mathrm{df}=2(\mathrm{P}=0.05) ; \mathrm{I}^{2}=67.42 \%$

Test for overall effect: $\mathrm{Z}=1.38(\mathrm{P}=0.17)$

9.1.2 Additional print-based support

Sheffer 2010

Simmons 2018

Simmons 2018

$77 / 380$

$176 / 614$

$207 / 622$

Unrod 2016

$499 / 1127$

Unrod 2016

$548 / 1142$

3885

Total events: 1507 (Treatment), 765 (Control)

Heterogeneity: $\operatorname{Tau}^{2}=0.02 ; \mathrm{Chi}^{2}=13.36, \mathrm{df}=4(\mathrm{P}=0.01) ; \mathrm{I}^{2}=70.05 \%$

Test for overall effect: $Z=2.03(P=0.04)$

9.1.3 Additional intervention delivered by computer or mobile phone

Hicks 2017

Japuntich 2006

Durmaz 2019

$1 / 5$

Wetter 2011

$21 / 140$

$18 / 44$

$39 / 151$

Subtotal $(95 \% \mathrm{CI})$

340
$77 / 512$

$74 / 319$

$74 / 319$

$270 / 594$

270/595

2339
Risk Ratio

M-H, Random, $95 \% \mathrm{Cl}$
Risk Ratio

M-H, Random, 95\% Cl
Total events: 79 (Treatment), 82 (Control)
$2 / 6$

$17 / 144$

$21 / 88$

$42 / 151$

389
Heterogeneity: $\mathrm{Tau}^{2}=0.03 ; \mathrm{Chi}^{2}=4.06, \mathrm{df}=3(\mathrm{P}=0.26) ; \mathrm{I}^{2}=26.04 \%$

Test for overall effect: $Z=0.99(P=0.32)$

9.1.4 Formulation of coping strategies

Van Osch 2008

$103 / 764 \quad 85 / 802$

764

Subtotal $(95 \% \mathrm{CI})$

802
$25.97 \%$

$34.75 \%$

$39.28 \%$

$100 \%$
$1.02[0.74,1.4]$

$1.47[1.18,1.84]$

$1.18[0.93,1.49]$
$1.07[0.9,1.28]$
$1.35[1.01,1.79]$

$1.24[0.98,1.56]$

$1.43[1.14,1.8]$

$0.97[0.87,1.09]$

$1.06[0.95,1.18]$

$1.16[1.01,1.33]$

Total events: 103 (Treatment), 85 (Control)

Heterogeneity: Not applicable

Test for overall effect: $\mathrm{Z}=1.75(\mathrm{P}=0.08)$ 
Analysis 9.2. Comparison 9 Interventions for smokers, tests of adjuncts to cessation programmes, Outcome 2 Combined behavioural and pharma interventions, cessation at longest follow-up.

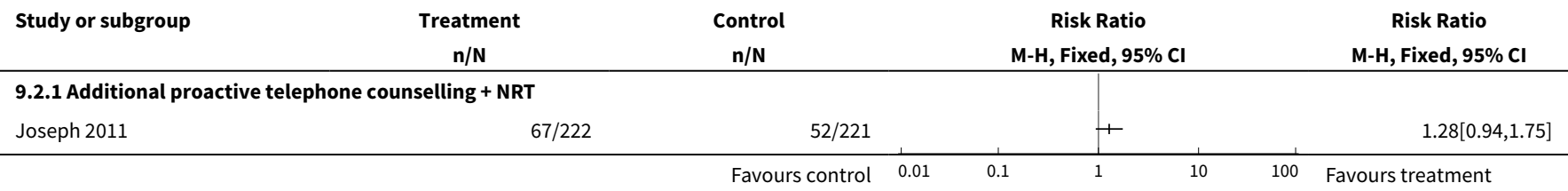

Comparison 10. Abstinent pregnant/postpartum women subgrouped by duration of prior abstinence

\begin{tabular}{|c|c|c|c|c|}
\hline Outcome or subgroup title & $\begin{array}{l}\text { No. of } \\
\text { studies }\end{array}$ & $\begin{array}{l}\text { No. of } \\
\text { partici- } \\
\text { pants }\end{array}$ & Statistical method & Effect size \\
\hline $\begin{array}{l}1 \text { Not smoking at delivery/last fol- } \\
\text { low-up prior to delivery }\end{array}$ & 8 & 1523 & Risk Ratio (M-H, Random, 95\% Cl) & $0.92[0.79,1.07]$ \\
\hline 1.1 Prior abstinence $\geq 4$ weeks & 2 & 420 & Risk Ratio (M-H, Random, 95\% Cl) & $0.84[0.65,1.08]$ \\
\hline 1.2 Prior abstinence $<4$ weeks & 1 & 33 & Risk Ratio (M-H, Random, 95\% Cl) & $1.81[0.48,6.83]$ \\
\hline $\begin{array}{l}\text { 1.3 Prior abstinence unclear/not re- } \\
\text { ported }\end{array}$ & 5 & 1070 & Risk Ratio (M-H, Random, 95\% Cl) & $0.95[0.77,1.17]$ \\
\hline $\begin{array}{l}2 \text { Not smoking at longest follow-up } \\
\text { after delivery }\end{array}$ & 14 & 4606 & Risk Ratio (M-H, Random, 95\% Cl) & $1.02[0.94,1.09]$ \\
\hline 2.1 Prior abstinence $\geq 4$ weeks & 3 & 924 & Risk Ratio (M-H, Random, 95\% Cl) & $0.97[0.79,1.20]$ \\
\hline 2.2 Prior abstinence $<4$ weeks & 2 & 733 & Risk Ratio (M-H, Random, 95\% Cl) & $0.95[0.84,1.08]$ \\
\hline $\begin{array}{l}2.3 \text { Prior abstinence unclear/not re- } \\
\text { ported }\end{array}$ & 9 & 2949 & Risk Ratio (M-H, Random, 95\% Cl) & $1.06[0.95,1.19]$ \\
\hline
\end{tabular}

Analysis 10.1. Comparison 10 Abstinent pregnant/postpartum women subgrouped by duration of prior abstinence, Outcome 1 Not smoking at delivery/last follow-up prior to delivery.

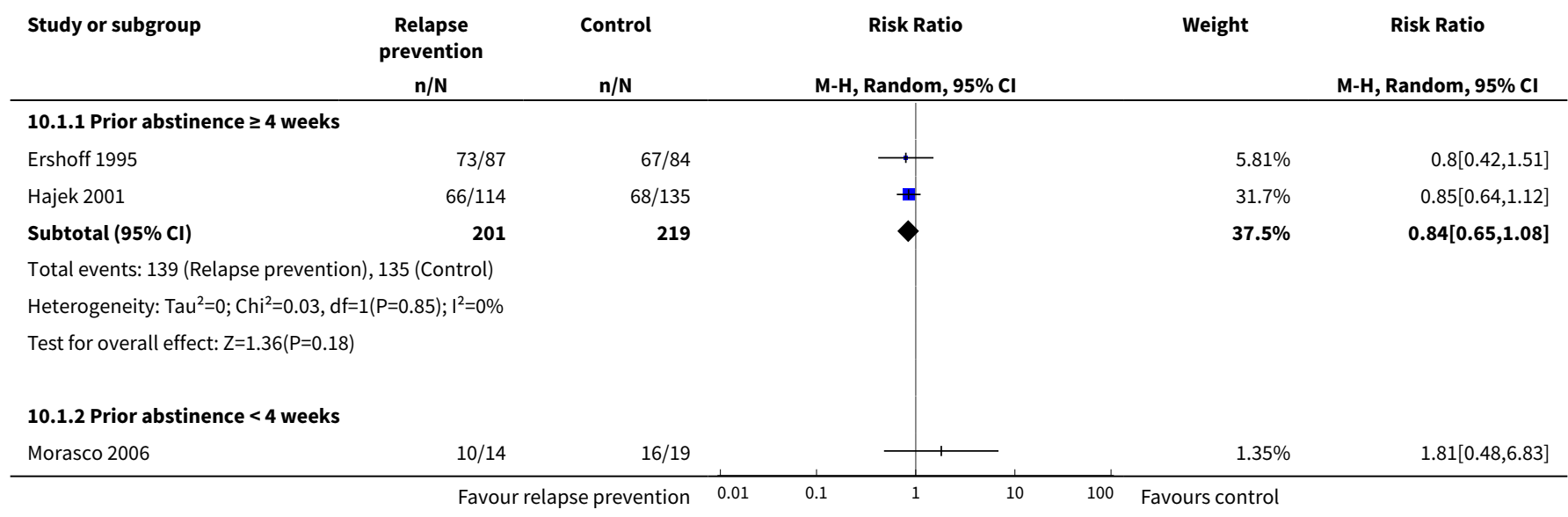




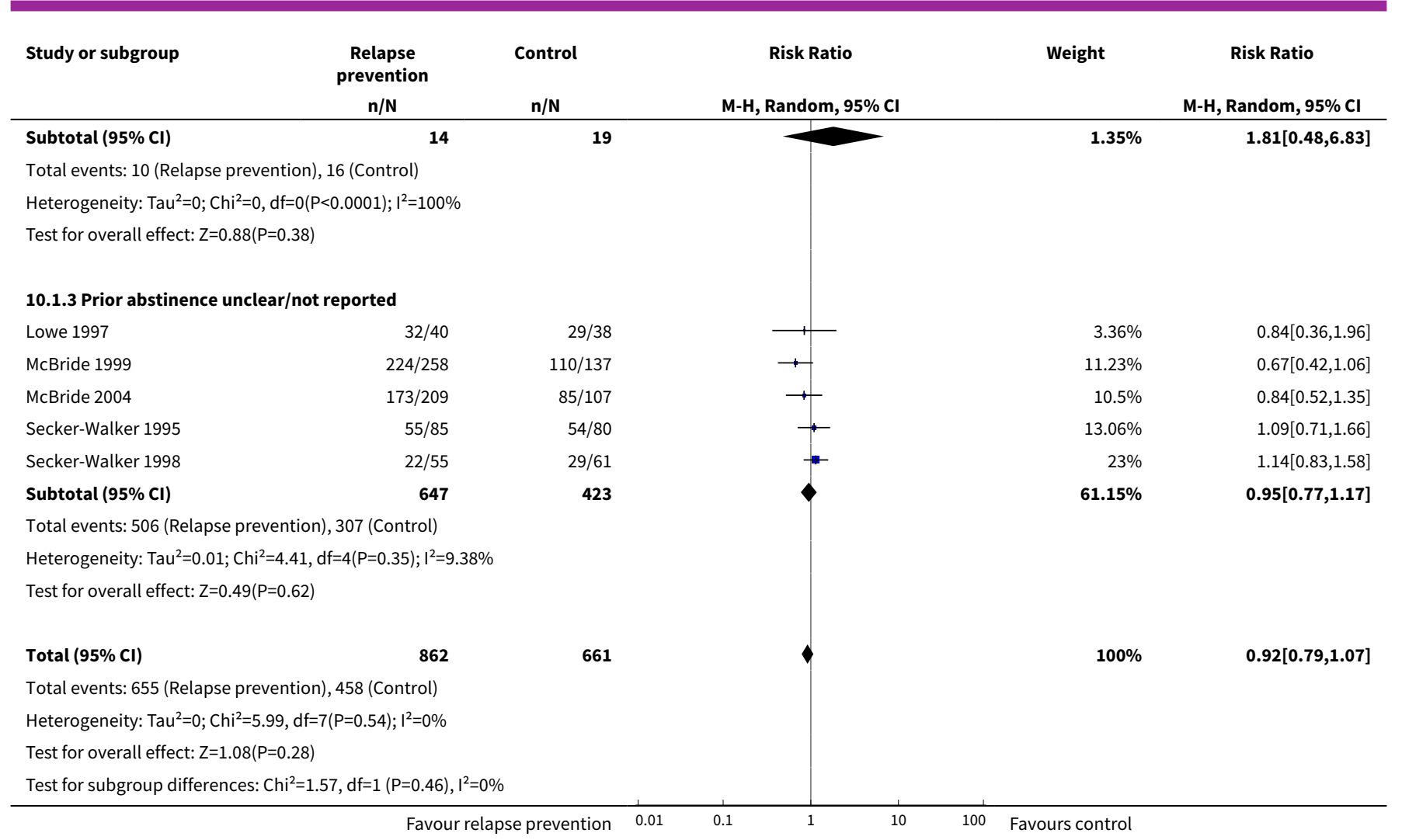

Analysis 10.2. Comparison 10 Abstinent pregnant/postpartum women subgrouped by duration of prior abstinence, Outcome 2 Not smoking at longest follow-up after delivery.

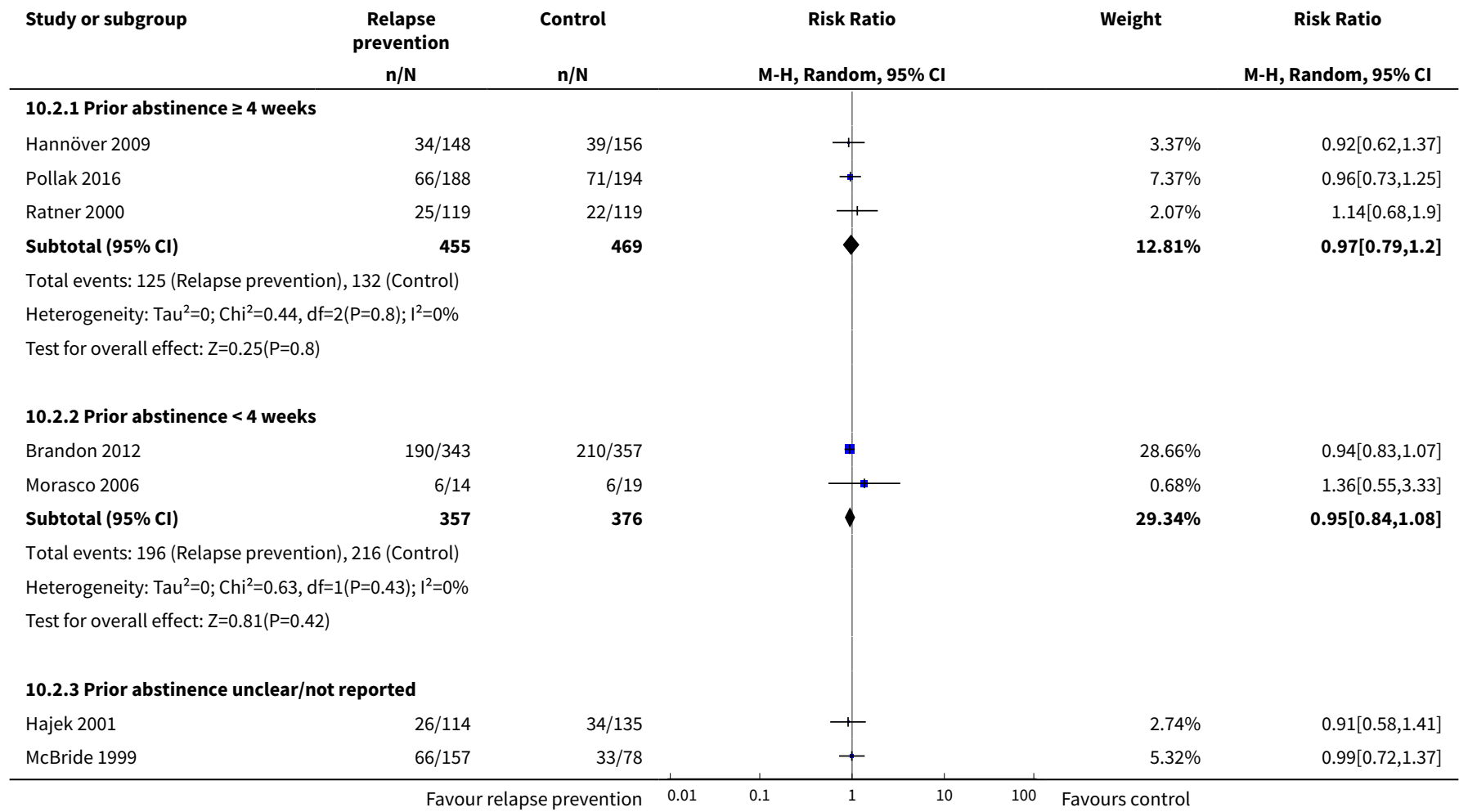




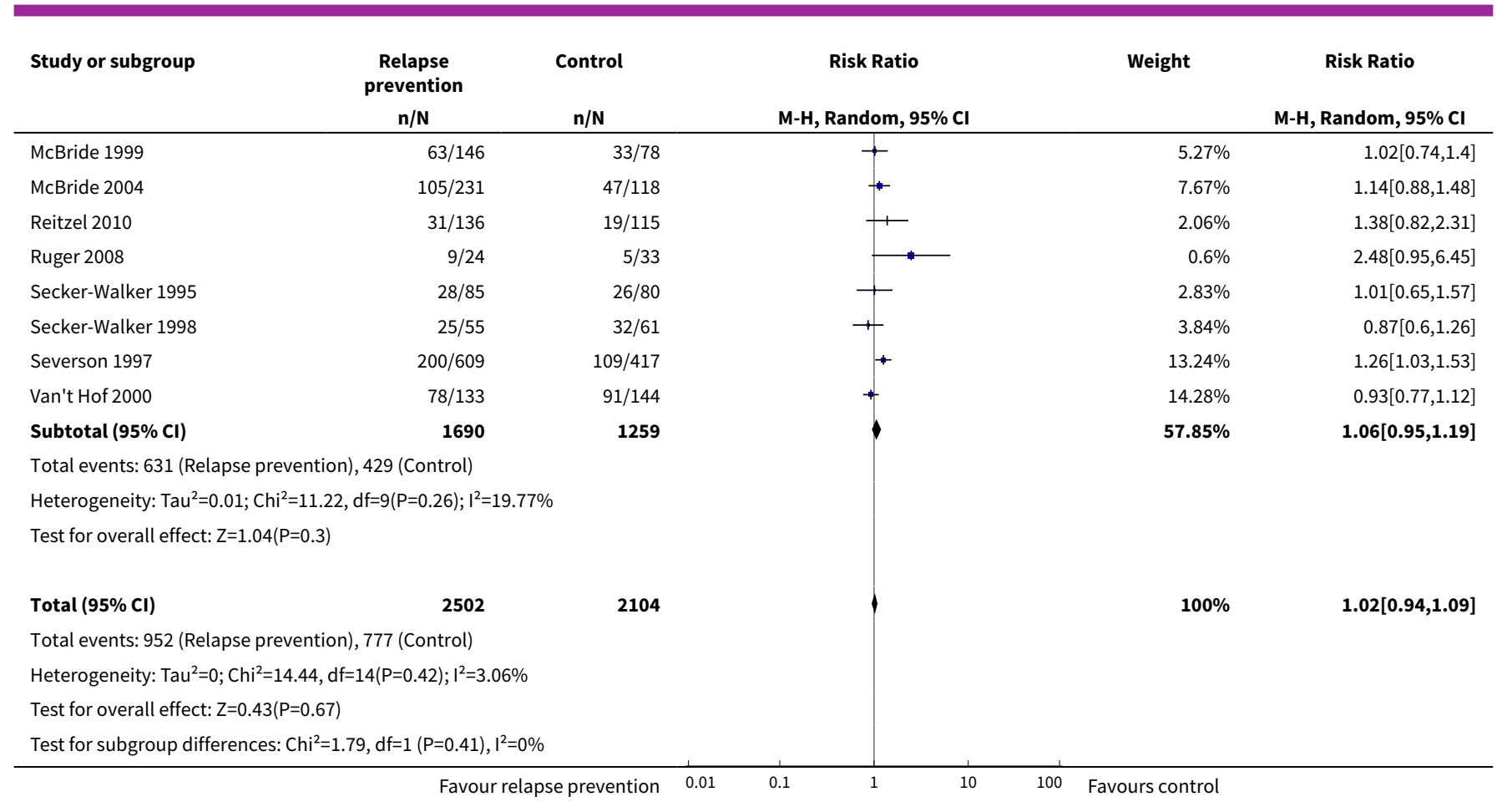

\section{Comparison 11. Abstinent hospitalised smokers subgrouped by duration of prior abstinence}

\begin{tabular}{|c|c|c|c|c|}
\hline Outcome or subgroup title & $\begin{array}{l}\text { No. of } \\
\text { studies }\end{array}$ & $\begin{array}{l}\text { No. of } \\
\text { partici- } \\
\text { pants }\end{array}$ & Statistical method & Effect size \\
\hline $\begin{array}{l}1 \text { Behavioural interventions, cessa- } \\
\text { tion at longest follow-up }\end{array}$ & 5 & 1385 & Risk Ratio (M-H, Random, 95\% Cl) & $1.10[0.82,1.47]$ \\
\hline 1.1 Prior abstinence $\geq 4$ weeks & 0 & 0 & Risk Ratio (M-H, Random, 95\% Cl) & $0.0[0.0,0.0]$ \\
\hline 1.2 Prior abstinence $<4$ weeks & 0 & 0 & Risk Ratio (M-H, Random, 95\% Cl) & $0.0[0.0,0.0]$ \\
\hline $\begin{array}{l}\text { 1.3 Prior abstinence unclear/not re- } \\
\text { ported }\end{array}$ & 5 & 1385 & Risk Ratio (M-H, Random, 95\% Cl) & $1.10[0.82,1.47]$ \\
\hline $\begin{array}{l}2 \text { Pharmacotherapy interventions, } \\
\text { cessation at longest follow-up }\end{array}$ & 2 & 1078 & Risk Ratio (M-H, Random, 95\% Cl) & $1.23[0.94,1.60]$ \\
\hline 2.1 Prior abstinence $\geq 4$ weeks & 0 & 0 & Risk Ratio (M-H, Random, 95\% Cl) & $0.0[0.0,0.0]$ \\
\hline 2.2 Prior abstinence $<4$ weeks & 0 & 0 & Risk Ratio (M-H, Random, 95\% Cl) & $0.0[0.0,0.0]$ \\
\hline $\begin{array}{l}\text { 2.3 Prior abstinence unclear/not re- } \\
\text { ported }\end{array}$ & 2 & 1078 & Risk Ratio (M-H, Random, 95\% Cl) & $1.23[0.94,1.60]$ \\
\hline
\end{tabular}


Analysis 11.1. Comparison 11 Abstinent hospitalised smokers subgrouped by duration of prior abstinence, Outcome 1 Behavioural interventions, cessation at longest follow-up.

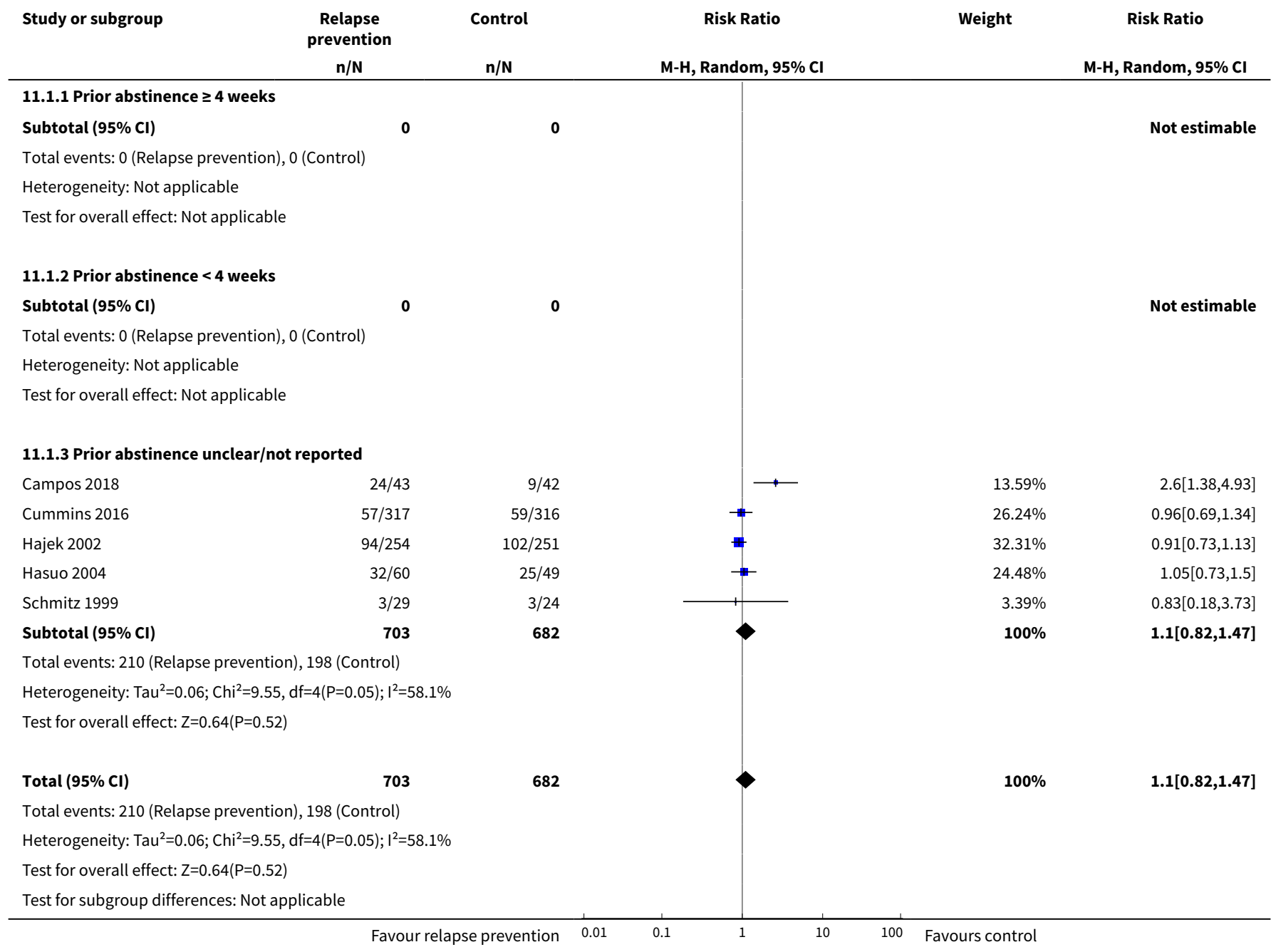

Analysis 11.2. Comparison 11 Abstinent hospitalised smokers subgrouped by duration of prior abstinence, Outcome 2 Pharmacotherapy interventions, cessation at longest follow-up.

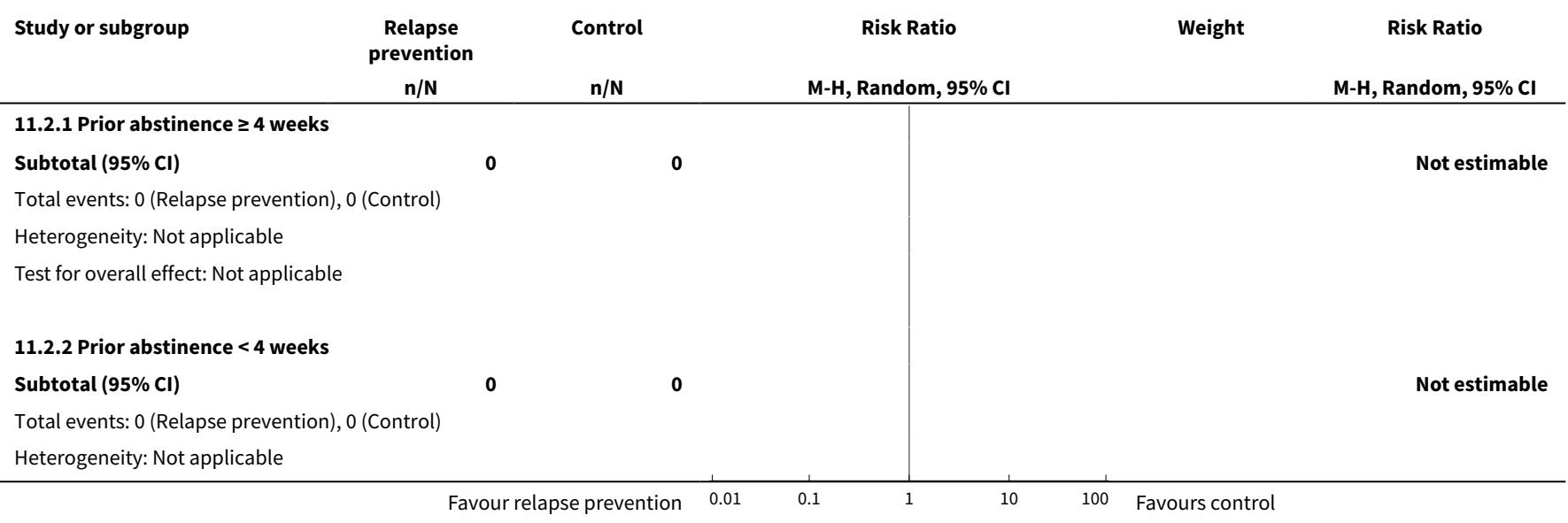




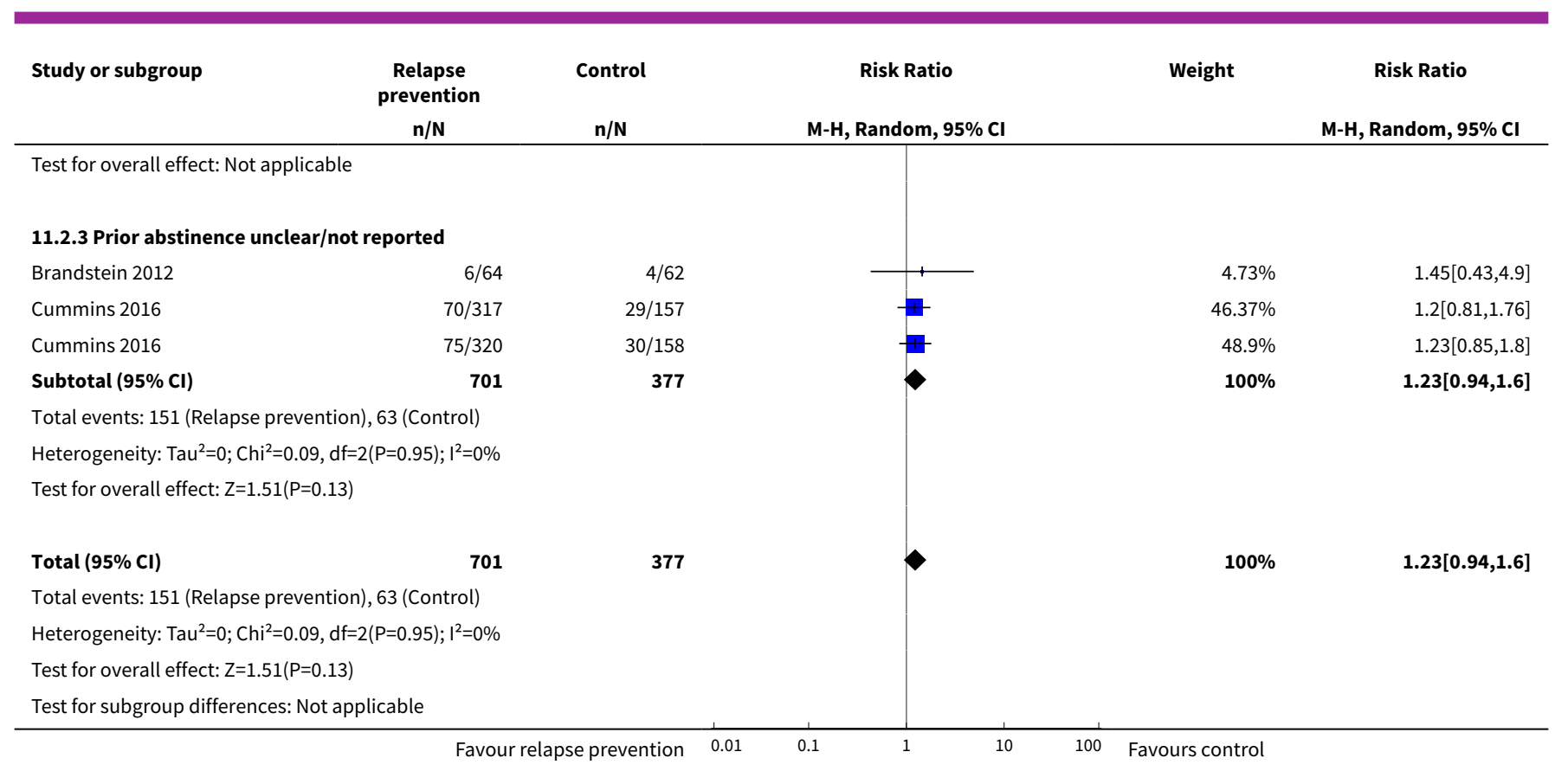

Comparison 12. Unaided abstainers subgrouped by duration of prior abstinence - Behavioural interventions

\begin{tabular}{llllll}
\hline Outcome or subgroup title & $\begin{array}{l}\text { No. of } \\
\text { studies }\end{array}$ & $\begin{array}{l}\text { No. of } \\
\text { partici- } \\
\text { pants }\end{array}$ & Statistical method & Effect size \\
\hline $\begin{array}{l}1 \text { Behavioural interventions for un- } \\
\text { aided abstainers }\end{array}$ & 5 & 3561 & Risk Ratio (M-H, Random, 95\% Cl) & $1.06[0.96,1.16]$ \\
\hline $\begin{array}{lllll}1.1 \text { Prior abstinence } \geq 4 \text { weeks } \\
1.2 \text { Prior abstinence <4 weeks }\end{array}$ & 0 & 0 & Risk Ratio (M-H, Random, 95\% Cl) & $0.0[0.0,0.0]$ \\
\hline $\begin{array}{l}1.3 \text { Prior abstinence unclear/not re- } \\
\text { ported }\end{array}$ & 1 & 3275 & Risk Ratio (M-H, Random, 95\% Cl) & $1.04[0.94,1.14]$ \\
\hline
\end{tabular}

Analysis 12.1. Comparison 12 Unaided abstainers subgrouped by duration of prior abstinence - Behavioural interventions, Outcome 1 Behavioural interventions for unaided abstainers.

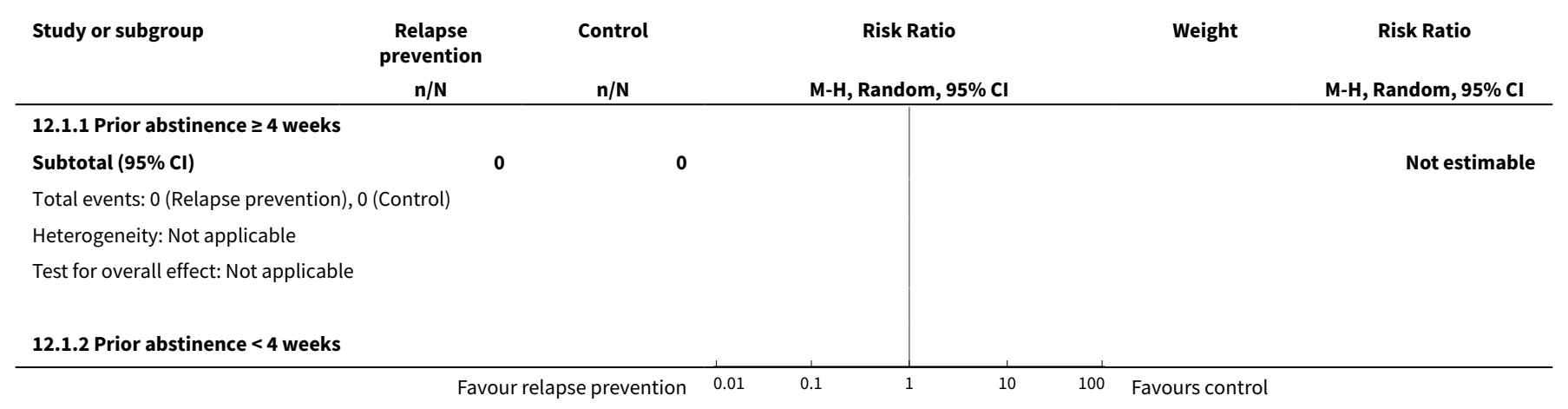




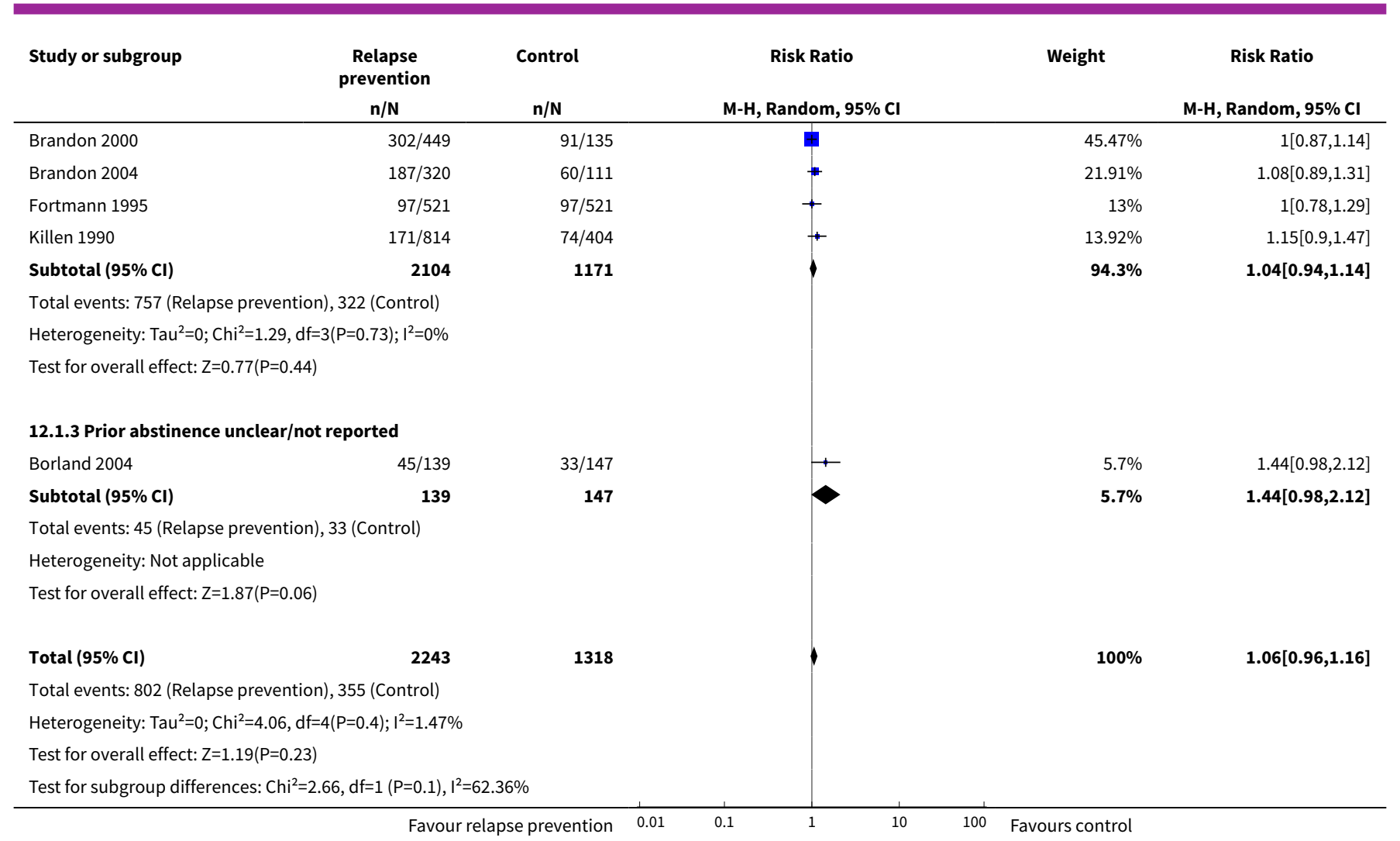

Comparison 13. Assisted abstainers subgrouped by duration of prior abstinence - Behavioural interventions

\begin{tabular}{lllll}
\hline Outcome or subgroup title & $\begin{array}{l}\text { No. of } \\
\text { studies }\end{array}$ & $\begin{array}{l}\text { No. of } \\
\text { partici- } \\
\text { pants }\end{array}$ & Statistical method & Effect size \\
\hline $\begin{array}{l}1 \text { Behavioural interventions for assist- } \\
\text { ed abstainers }\end{array}$ & 11 & 5523 & Risk Ratio (M-H, Random, 95\% Cl) & $0.98[0.87,1.11]$ \\
\hline 1.1 Prior abstinence $\geq 4$ weeks & 2 & 1660 & Risk Ratio (M-H, Random, 95\% Cl) & $1.03[0.77,1.37]$ \\
\hline 1.2 Prior abstinence < 4 weeks & 6 & 3363 & Risk Ratio (M-H, Random, 95\% Cl) & $1.03[0.85,1.25]$ \\
\hline $\begin{array}{l}1.3 \text { Prior abstinence unclear/not re- } \\
\text { ported }\end{array}$ & 3 & 500 & Risk Ratio (M-H, Random, 95\% Cl) & $0.84[0.68,1.04]$ \\
\hline
\end{tabular}

Analysis 13.1. Comparison 13 Assisted abstainers subgrouped by duration of prior abstinence - Behavioural interventions, Outcome 1 Behavioural interventions for assisted abstainers.

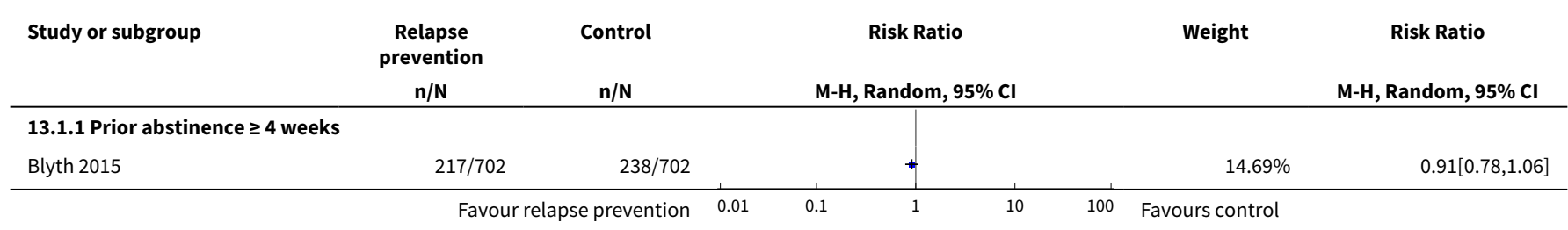




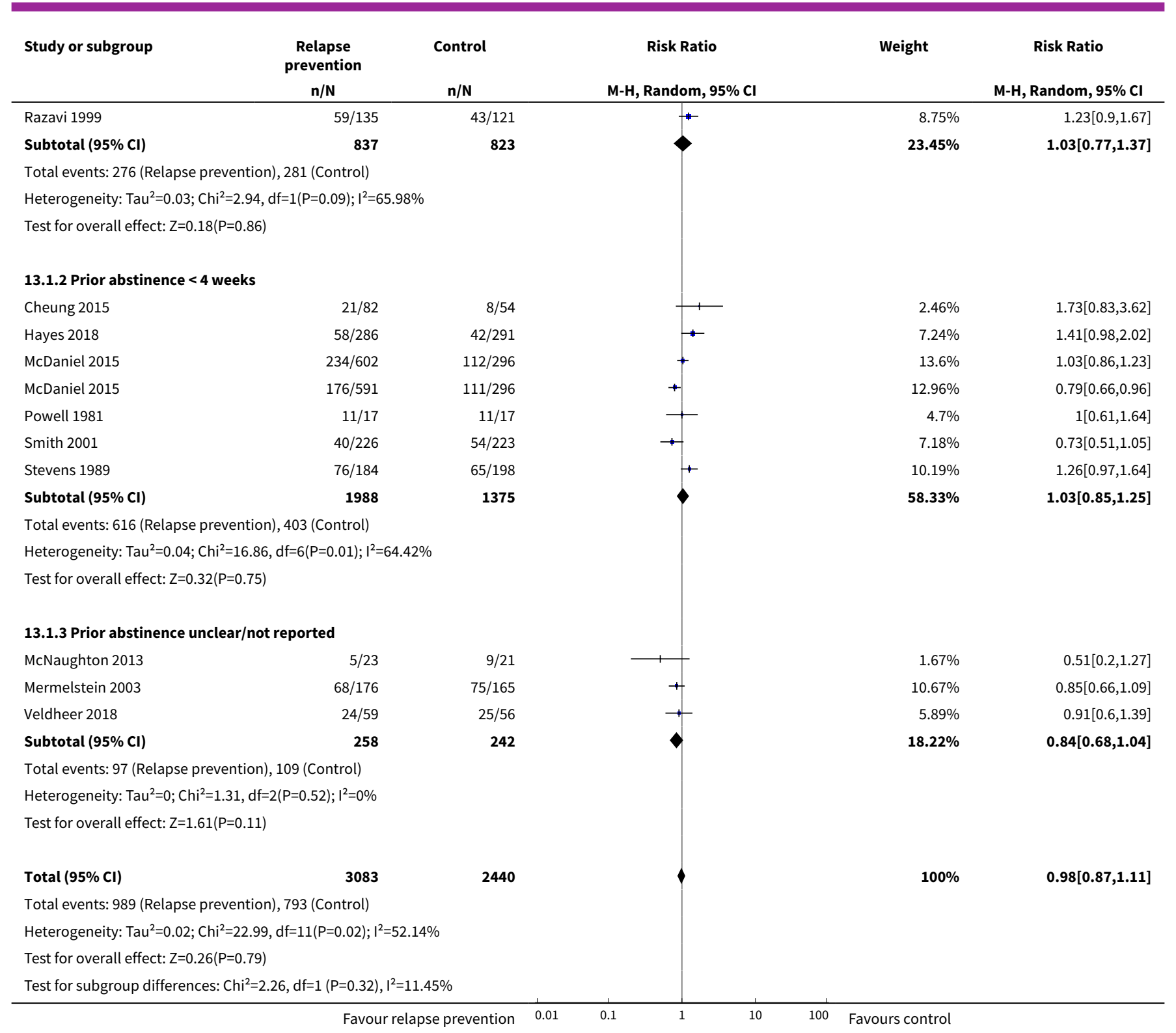

\section{Comparison 14. Unaided abstainers subgrouped by duration of prior abstinence - Pharmacotherapy}

\begin{tabular}{lllll}
\hline Outcome or subgroup title & $\begin{array}{l}\text { No. of } \\
\text { studies }\end{array}$ & $\begin{array}{l}\text { No. of } \\
\text { partici- } \\
\text { pants }\end{array}$ & Statistical method & Effect size \\
\hline $\begin{array}{l}1 \text { Nicotine gum vs placebo for unaid- } \\
\text { ed abstainers }\end{array}$ & 2 & 2261 & Risk Ratio (M-H, Random, 95\% Cl) & $1.24[1.04,1.47]$ \\
\hline $\begin{array}{lllll}1.1 \text { Prior abstinence } \geq 4 \text { weeks } \\
1.2 \text { Prior abstinence < 4 weeks }\end{array}$ & 0 & 0 & Risk Ratio (M-H, Random, 95\% Cl) & $0.0[0.0,0.0]$ \\
\hline $\begin{array}{l}1.3 \text { Prior abstinence unclear/not re- } \\
\text { ported }\end{array}$ & 0 & 2261 & Risk Ratio (M-H, Random, 95\% Cl) & $1.24[1.04,1.47]$ \\
\hline
\end{tabular}


Analysis 14.1. Comparison 14 Unaided abstainers subgrouped by duration of prior abstinence - Pharmacotherapy, Outcome 1 Nicotine gum vs placebo for unaided abstainers.

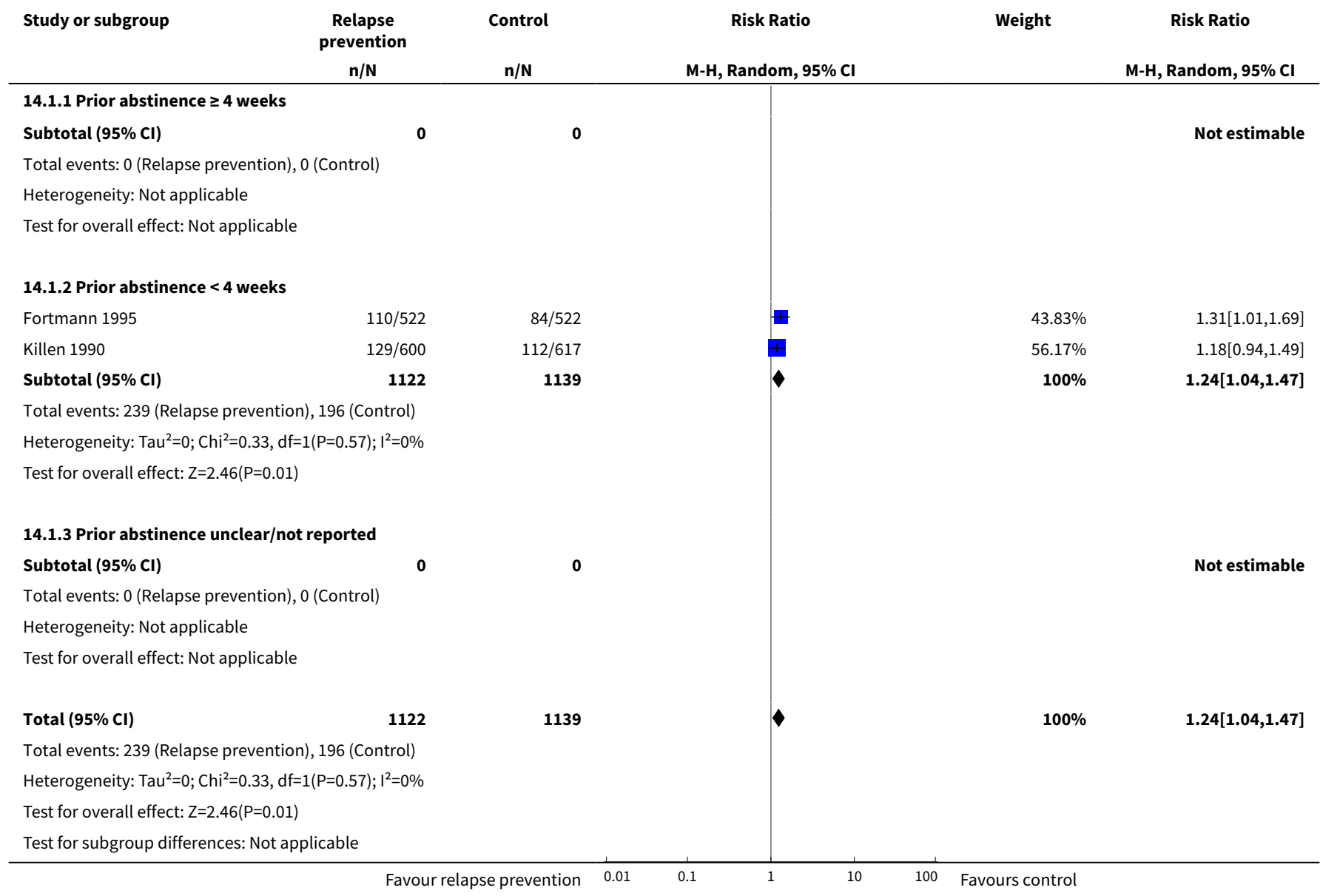

Comparison 15. Assited abstainers subgrouped by duration of prior abstinence - Pharmacotherapy

\begin{tabular}{lllll}
\hline Outcome or subgroup title & $\begin{array}{l}\text { No. of } \\
\text { studies }\end{array}$ & $\begin{array}{l}\text { No. of } \\
\text { partici- } \\
\text { pants }\end{array}$ & Statistical method & Effect size \\
\hline $\begin{array}{l}1 \text { Nicotine replacement therapy ver- } \\
\text { sus placebo. Cessation } 12 \text { months } \\
\text { after quit date }\end{array}$ & 2 & 553 & Risk Ratio (M-H, Random, 95\% Cl) & $1.04[0.77,1.40]$ \\
\hline $\begin{array}{l}1.1 \text { Prior abstinence } \geq 4 \text { weeks } \\
1.2 \text { Prior abstinence < 4 weeks }\end{array}$ & 0 & 0 & Risk Ratio (M-H, Random, 95\% Cl) & $0.0[0.0,0.0]$ \\
\hline $\begin{array}{l}1.3 \text { Prior abstinence unclear/not re- } \\
\text { ported }\end{array}$ & 2 & 0 & Risk Ratio (M-H, Random, 95\% Cl) & $0.0[0.0,0.0]$ \\
\hline $\begin{array}{l}2 \text { Bupropion vs placebo. Cessation } \\
12 \text { months + after quit date }\end{array}$ & 6 & 553 & Risk Ratio (M-H, Random, 95\% Cl) & $1.04[0.77,1.40]$ \\
\hline
\end{tabular}




\begin{tabular}{|c|c|c|c|c|}
\hline Outcome or subgroup title & $\begin{array}{l}\text { No. of } \\
\text { studies }\end{array}$ & $\begin{array}{l}\text { No. of } \\
\text { partici- } \\
\text { pants }\end{array}$ & Statistical method & Effect size \\
\hline 2.1 Prior abstinence $\geq 4$ weeks & 0 & 0 & Risk Ratio (M-H, Random, 95\% Cl) & $0.0[0.0,0.0]$ \\
\hline 2.2 Prior abstinence $<4$ weeks & 2 & 472 & Risk Ratio (M-H, Random, 95\% Cl) & $1.10[0.83,1.46]$ \\
\hline $\begin{array}{l}\text { 2.3 Prior abstinence unclear/not re- } \\
\text { ported }\end{array}$ & 4 & 1225 & Risk Ratio (M-H, Random, 95\% Cl) & $1.16[0.96,1.41]$ \\
\hline $\begin{array}{l}3 \text { Combination NRT \& bupropion vs } \\
\text { placebo. Cessation at longest fol- } \\
\text { low-up }\end{array}$ & 2 & 243 & Risk Ratio (M-H, Random, 95\% Cl) & $1.11[0.49,2.54]$ \\
\hline 3.1 Prior abstinence $\geq 4$ weeks & 0 & 0 & Risk Ratio (M-H, Random, 95\% Cl) & $0.0[0.0,0.0]$ \\
\hline 3.2 Prior abstinence $<4$ weeks & 0 & 0 & Risk Ratio (M-H, Random, 95\% Cl) & $0.0[0.0,0.0]$ \\
\hline $\begin{array}{l}\text { 3.3 Prior abstinence unclear/not re- } \\
\text { ported }\end{array}$ & 2 & 243 & Risk Ratio (M-H, Random, 95\% Cl) & $1.11[0.49,2.54]$ \\
\hline $\begin{array}{l}4 \text { Varenicline vs placebo. Cessation } \\
12 \text { months + after quit date }\end{array}$ & 2 & 1297 & Risk Ratio (M-H, Random, 95\% Cl) & $1.75[0.70,4.34]$ \\
\hline 4.1 Prior abstinence $\geq 4$ weeks & 0 & 0 & Risk Ratio (M-H, Random, 95\% Cl) & $0.0[0.0,0.0]$ \\
\hline 4.2 Prior abstinence $<4$ weeks & 2 & 1297 & Risk Ratio (M-H, Random, 95\% Cl) & $1.75[0.70,4.34]$ \\
\hline $\begin{array}{l}4.3 \text { Prior abstinence unclear/not re- } \\
\text { ported }\end{array}$ & 0 & 0 & Risk Ratio (M-H, Random, 95\% Cl) & $0.0[0.0,0.0]$ \\
\hline $\begin{array}{l}5 \text { Rimonabant vs placebo. Cessation } \\
12 \text { months + after quit date }\end{array}$ & 1 & 1017 & Risk Ratio (M-H, Random, 95\% Cl) & $1.29[1.08,1.55]$ \\
\hline 5.1 Prior abstinence $\geq 4$ weeks & 0 & 0 & Risk Ratio (M-H, Random, 95\% Cl) & $0.0[0.0,0.0]$ \\
\hline 5.2 Prior abstinence $<4$ weeks & 0 & 0 & Risk Ratio (M-H, Random, 95\% Cl) & $0.0[0.0,0.0]$ \\
\hline $\begin{array}{l}5.3 \text { Prior abstinence unclear/not re- } \\
\text { ported }\end{array}$ & 1 & 1017 & Risk Ratio (M-H, Random, 95\% Cl) & $1.29[1.08,1.55]$ \\
\hline
\end{tabular}

Analysis 15.1. Comparison 15 Assited abstainers subgrouped by duration of prior abstinence - Pharmacotherapy, Outcome 1 Nicotine replacement therapy versus placebo. Cessation 12 months + after quit date.

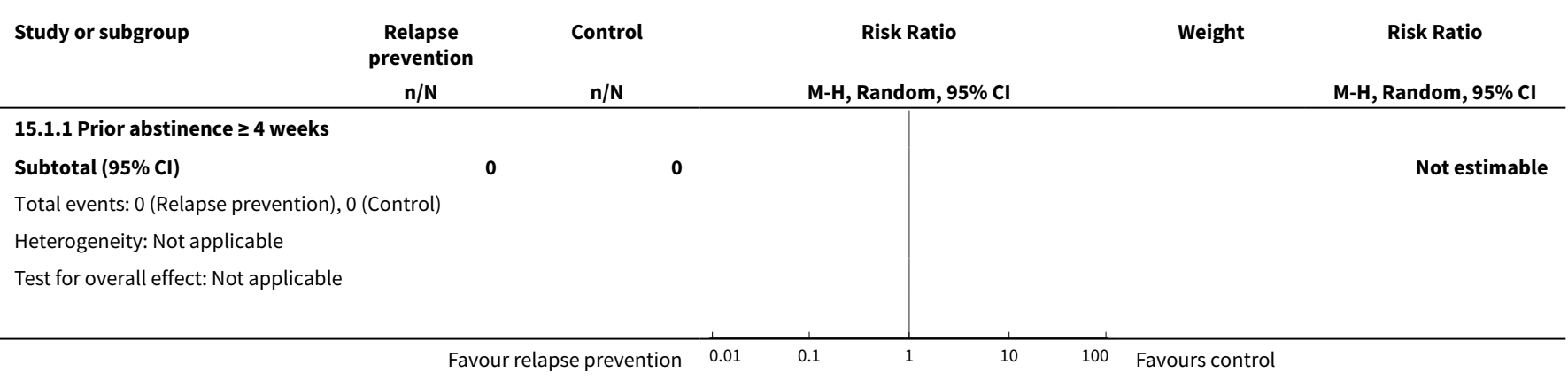




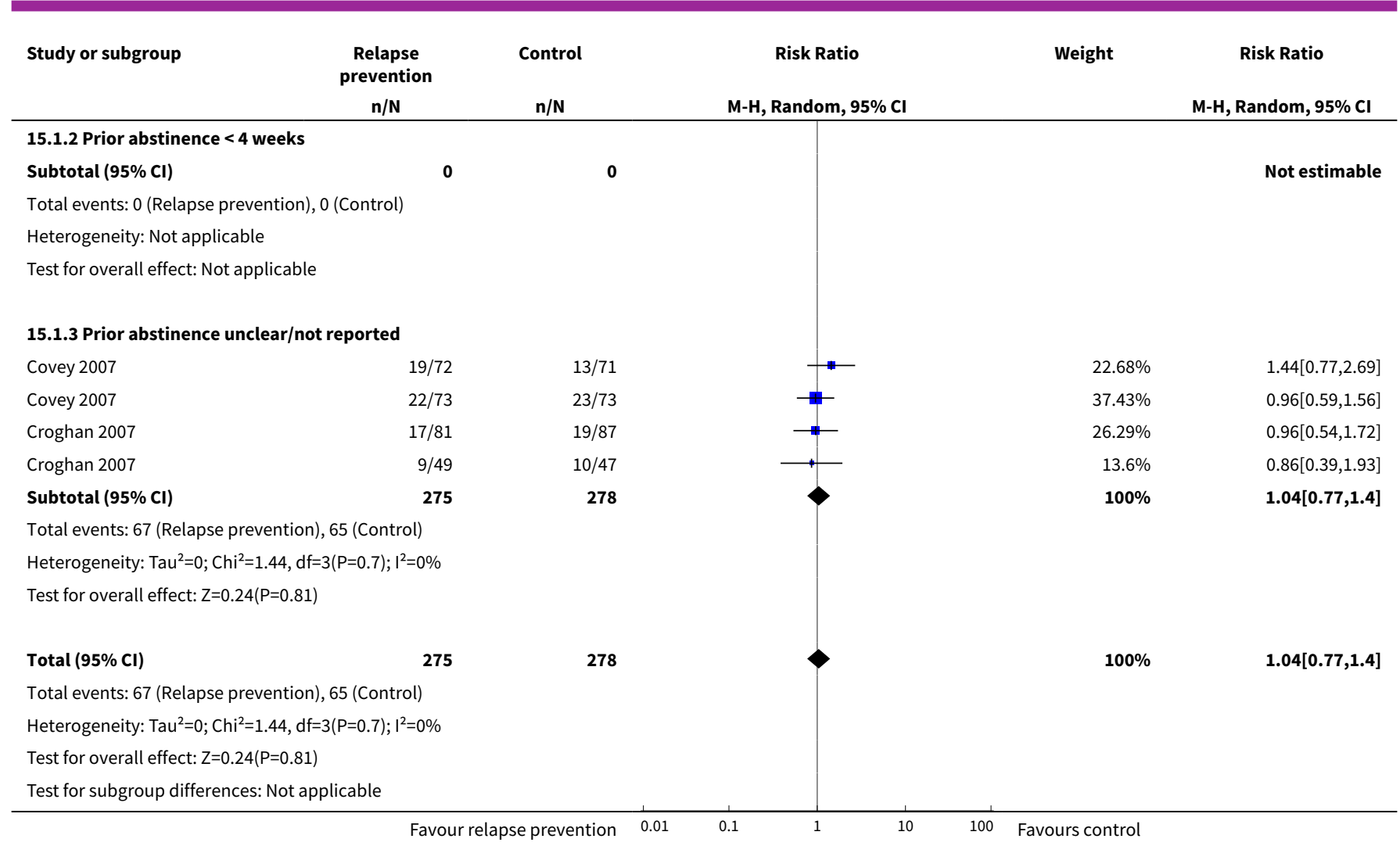

\section{Analysis 15.2. Comparison 15 Assited abstainers subgrouped by duration of prior abstinence - Pharmacotherapy, Outcome 2 Bupropion vs placebo. Cessation 12 months + after quit date.}

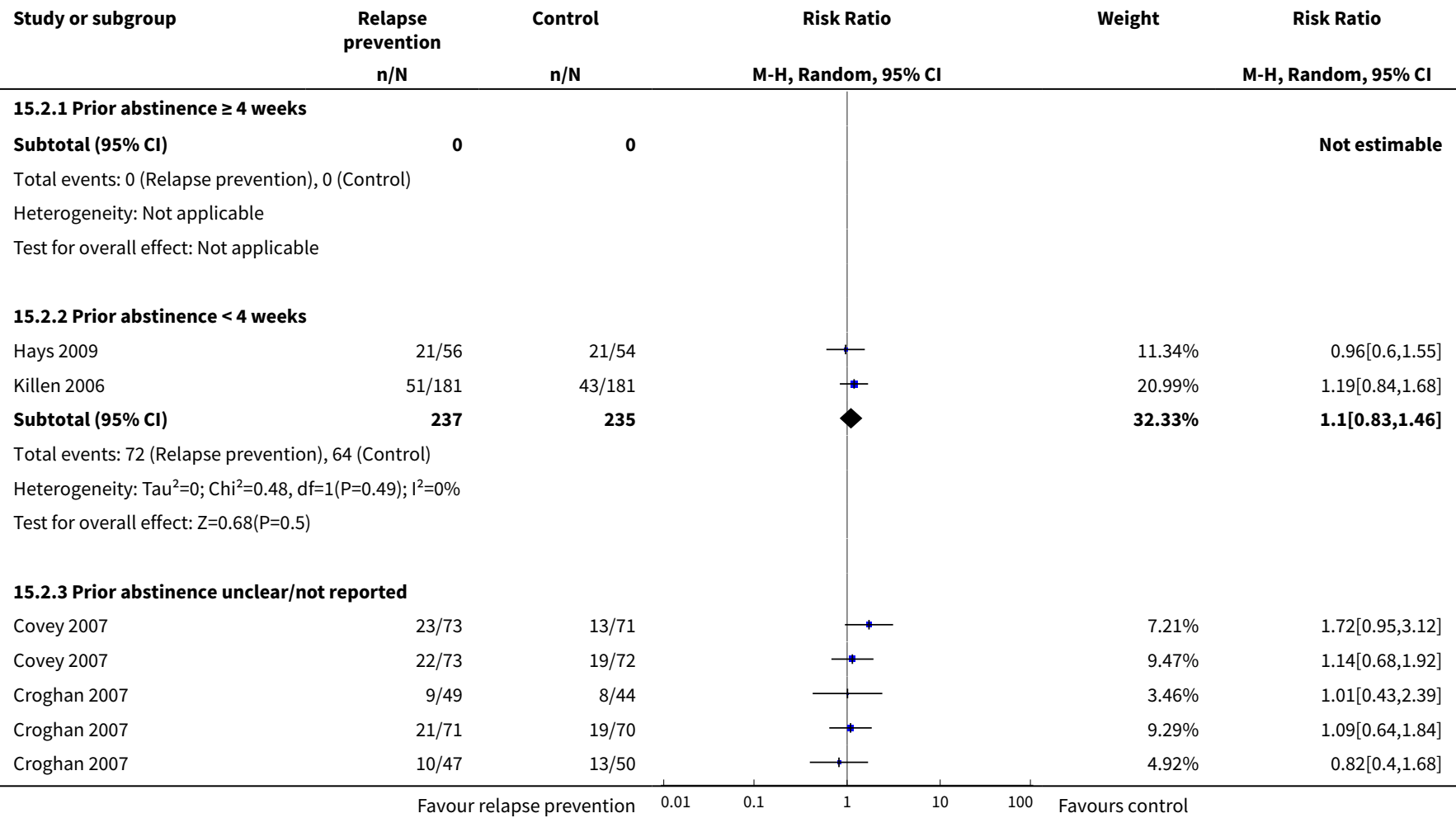




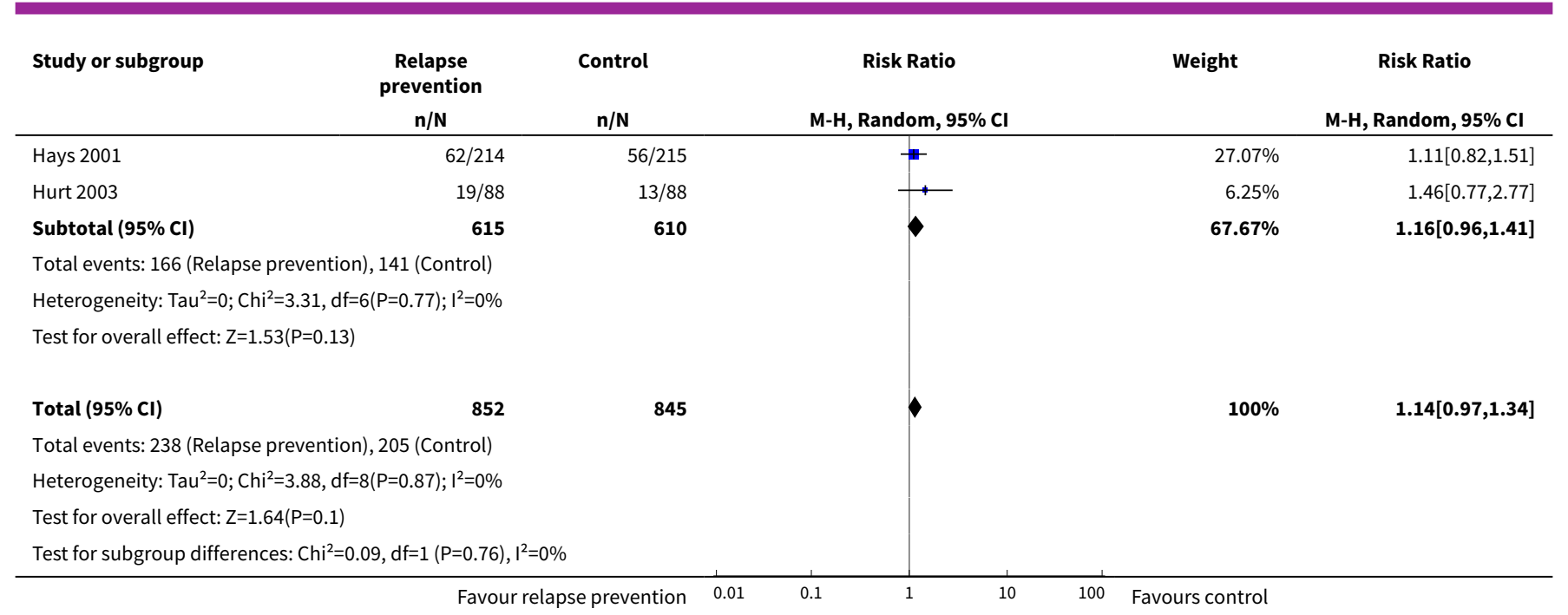

Analysis 15.3. Comparison 15 Assited abstainers subgrouped by duration of prior abstinence Pharmacotherapy, Outcome 3 Combination NRT \& bupropion vs placebo. Cessation at longest follow-up.

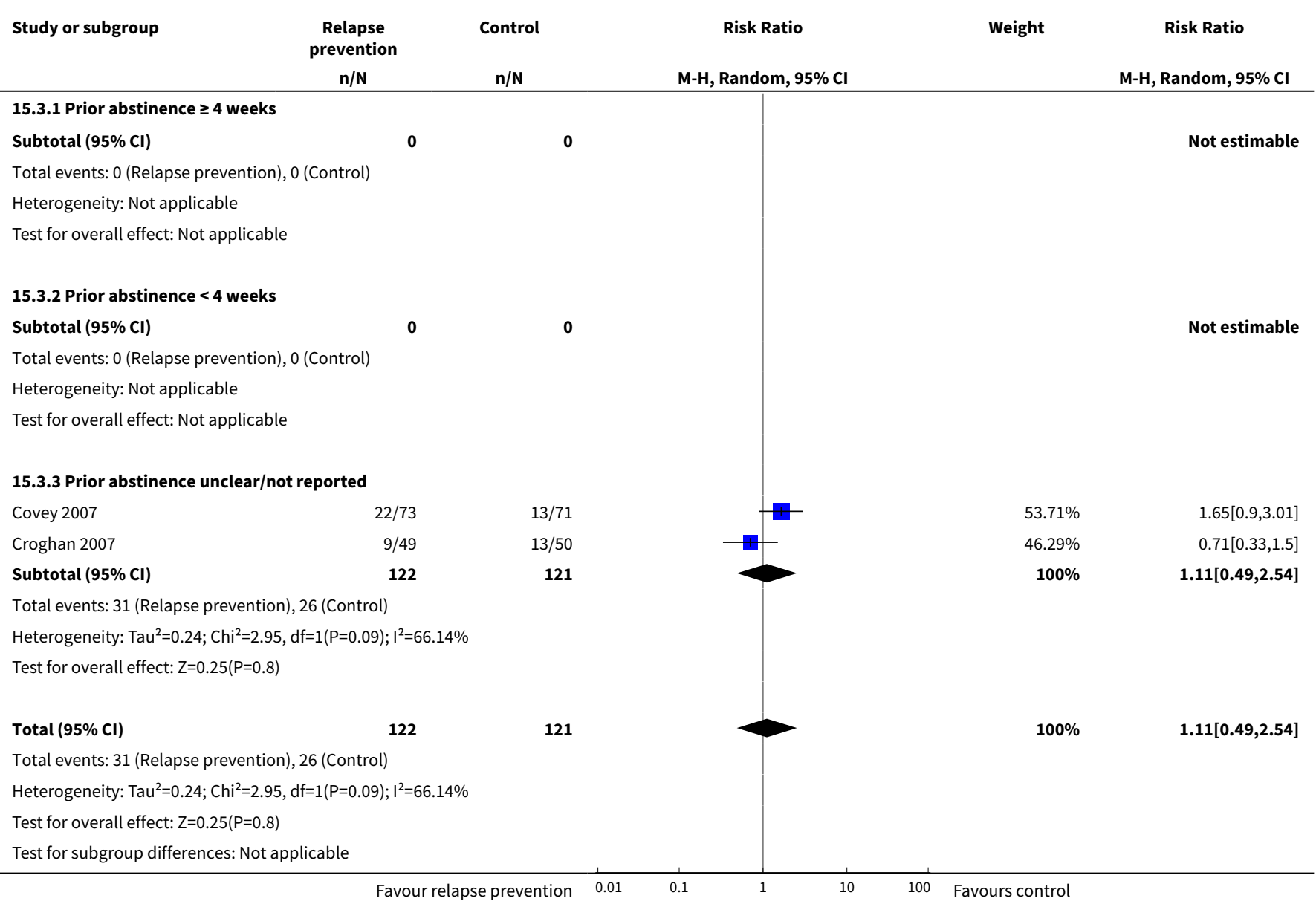


Analysis 15.4. Comparison 15 Assited abstainers subgrouped by duration of prior abstinence - Pharmacotherapy, Outcome 4 Varenicline vs placebo. Cessation 12 months + after quit date.

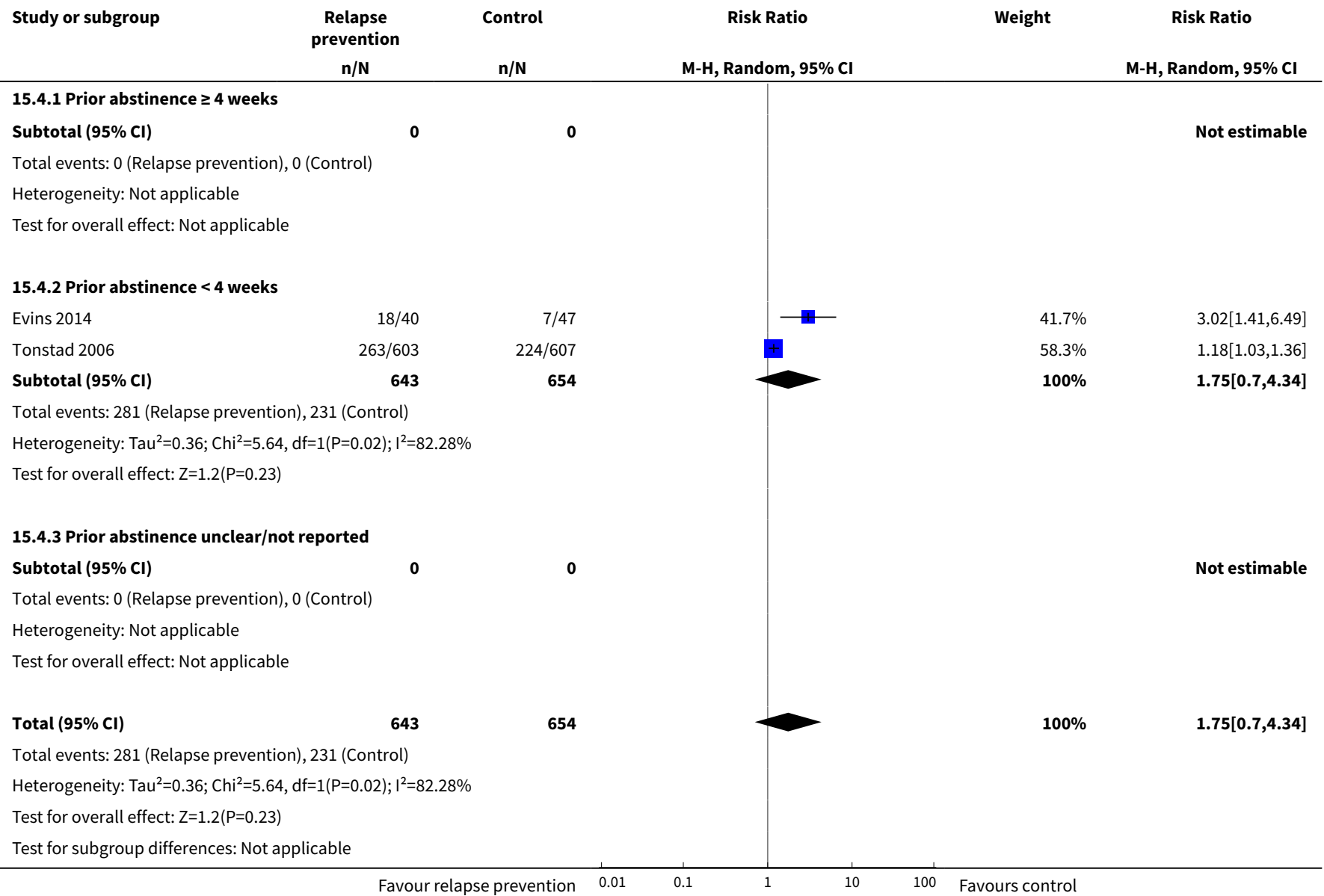

Analysis 15.5. Comparison 15 Assited abstainers subgrouped by duration of prior abstinence - Pharmacotherapy, Outcome 5 Rimonabant vs placebo. Cessation 12 months + after quit date.

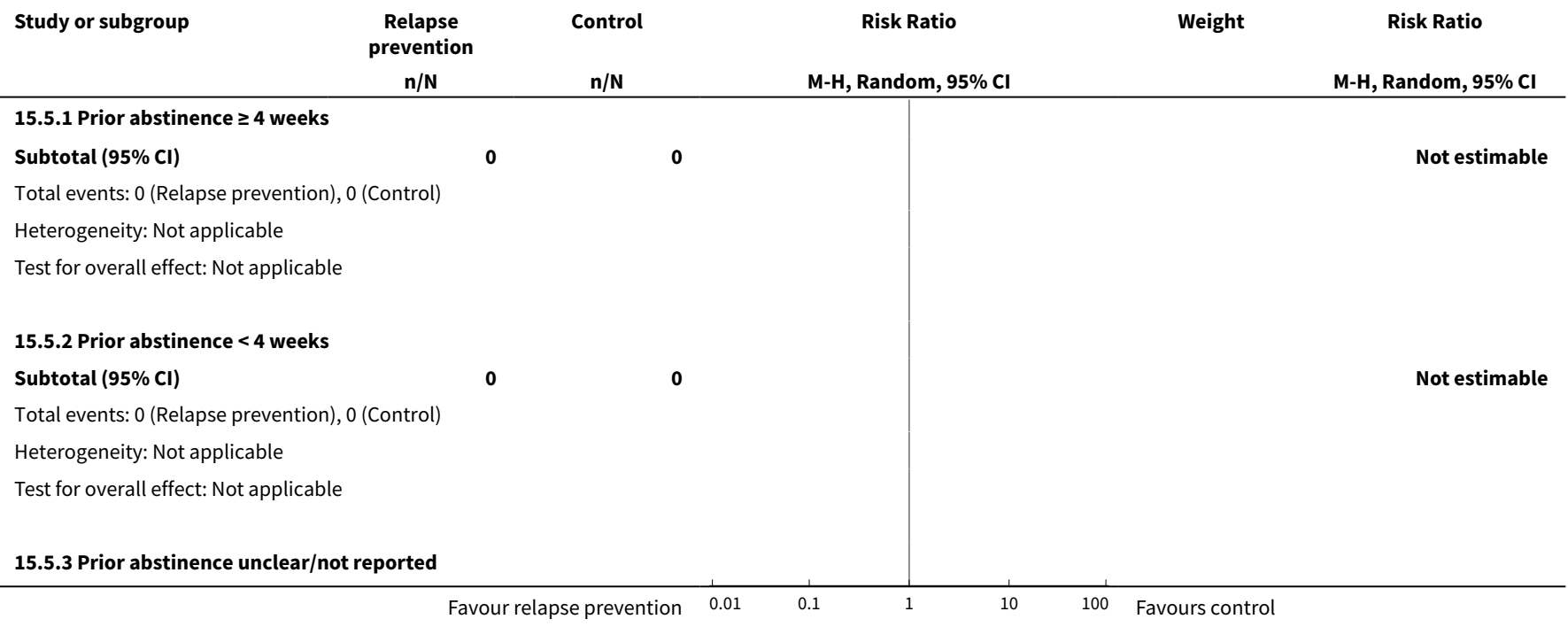




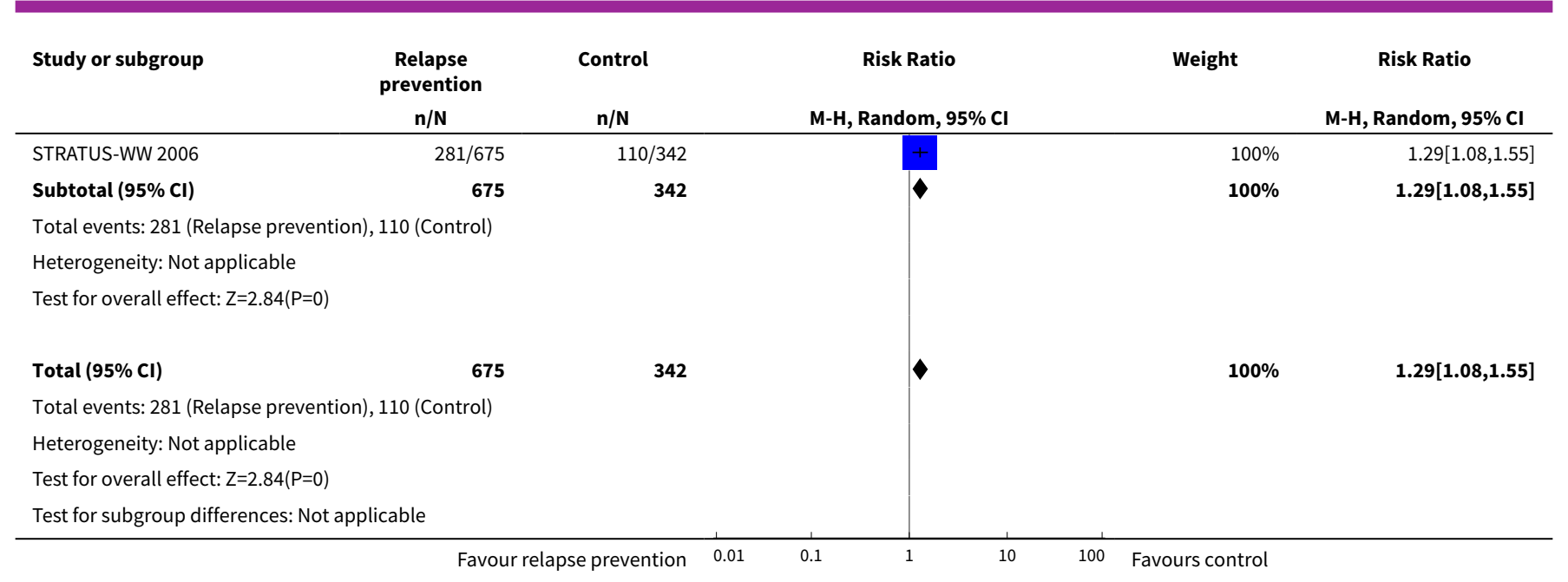

\section{ADDITIONAL TABLES}

Table 1. Duration of prior abstinence in studies recruiting abstainers

\begin{tabular}{|c|c|}
\hline Study ID & Duration of prior abstinence \\
\hline Blyth 2015 & 4 weeks \\
\hline Borland 2004 & Unclear/varied \\
\hline Brandon 2000 & 7 days \\
\hline Brandon 2004 & 7 days \\
\hline Brandon 2012 & 7 days \\
\hline Brandstein 2012 & Unclear/varied \\
\hline Campos 2018 & Unclear/varied \\
\hline Cheung 2015 & 7 days \\
\hline Conway 2004 & 2 months \\
\hline Covey 2007 & Unclear/varied \\
\hline Croghan 2007 & Unclear/varied \\
\hline Ershoff 1995 & Mean 31 days \\
\hline Evins 2014 & 2 weeks \\
\hline Fortmann 1995 & 24 hours \\
\hline Hajek 2001 & Mean 7 weeks \\
\hline Hajek 2002 & Unclear/varied \\
\hline
\end{tabular}


Table 1. Duration of prior abstinence in studies recruiting abstainers (Continued)

\begin{tabular}{|c|c|}
\hline Hannöver 2009 & 4 weeks \\
\hline Hasuo 2004 & Unclear/varied \\
\hline Hayes 2018 & 24 hours \\
\hline Hays 2001 & Unclear/varied \\
\hline Hays 2009 & 1 week \\
\hline Hurt 2003 & Unclear/varied \\
\hline Killen 1990 & 48 hours \\
\hline Klesges 1999 & 6 weeks \\
\hline Klesges 2006 & 6 weeks \\
\hline Levine 2016 & 2 weeks \\
\hline Lowe 1997 & Unclear/varied \\
\hline Mayer 2010 & 4 weeks \\
\hline McBride 1999 & Unclear/varied \\
\hline McBride 2004 & Unclear/varied \\
\hline McDaniel 2015 & 24 hours \\
\hline McNaughton 2013 & Unclear/varied \\
\hline Mermelstein 2003 & Unclear/varied \\
\hline Morasco 2006 & 7 days \\
\hline Pbert 2004 & Unclear/varied \\
\hline Pollak 2016 & 1 month \\
\hline Powell 1981 & 5 days \\
\hline Ratner 2000 & 6 weeks \\
\hline Razavi 1999 & 1 month \\
\hline Reitzel 2010 & Unclear/varied \\
\hline Ruger 2008 & Unclear/varied \\
\hline Schmitz 1999 & Unclear/varied \\
\hline Secker-Walker 1995 & Unclear/varied \\
\hline Secker-Walker 1998 & Unclear/varied \\
\hline
\end{tabular}


Table 1. Duration of prior abstinence in studies recruiting abstainers (Continued)

\begin{tabular}{ll} 
Severson 1997 & Unclear/varied \\
\hline Smith 2001 & 1 week \\
\hline Stevens 1989 & Unclear/varied \\
\hline STRATUS-WW 2006 & 1 week \\
\hline Tonstad 2006 & Unclear/varied \\
\hline Van't Hof 2000 & Unclear/varied \\
\hline Veldheer 2018 & Unc
\end{tabular}

\section{APPENDICES}

\section{Appendix 1. CRS search strategy}

\#1 relapse prevention:TI,AB,MH,EMT,XKY

\#2 maintenance:TI,AB,MH,EMT,XKY

\#3 (relapse NEAR prevent $\left.{ }^{\star}\right): T I, A B, M H, E M T, X K Y$

\#4 (relapse* NEAR smok ${ }^{\star}$ ):TI,AB,MH,EMT,XKY

$\# 5$ recurrence: $\mathrm{MH}, \mathrm{XKY}$

\#6 \#1 OR \#2 OR \#3 OR \#4 OR \#5

\section{WHAT'S NEW}

\begin{tabular}{lll}
\hline Date & Event & Description \\
\hline 8 August 2019 & $\begin{array}{l}\text { New citation required but conclusions } \\
\text { have not changed }\end{array}$ & Conclusions unchanged \\
\hline 8 August 2019 & New search has been performed & Searches updated. Five new included studies \\
\hline
\end{tabular}

\section{H I S T O RY}

Protocol first published: Issue 1, 2003

Review first published: Issue 1, 2005

\begin{tabular}{lll}
\hline Date & Event & Description \\
\hline 4 October 2018 & $\begin{array}{l}\text { New citation required and conclusions } \\
\text { have changed }\end{array}$ & Conclusions changed \\
\hline 4 October 2018 & New search has been performed & Searches updated. Fifteen new included studies \\
\hline 3 June 2013 & $\begin{array}{l}\text { New citation required but conclusions } \\
\text { have not changed }\end{array}$ & $\begin{array}{l}\text { Nine new included studies have not changed pooled results or } \\
\text { conclusions. }\end{array}$ \\
\hline
\end{tabular}




\begin{tabular}{lll}
\hline Date & Event & Description \\
\hline 3 June 2013 & New search has been performed & $\begin{array}{l}\text { New search run 2013; nine included studies added and risk of } \\
\text { bias tables updated to current Cochrane tool. }\end{array}$ \\
\hline 22 October 2008 & $\begin{array}{l}\text { New citation required and conclusions } \\
\text { have changed }\end{array}$ & $\begin{array}{l}\text { Includes evidence from one trial that extended treatment with } \\
\text { varenicline reduces relapse }\end{array}$ \\
\hline 21 October 2008 & New search has been performed & Updated for issue 1, 2009 with 15 new included trials. \\
\hline 20 October 2008 & Amended & Converted to new review format. \\
\hline
\end{tabular}

\section{CONTRIBUTIONS OF AUTHORS}

$\mathrm{PH}, \mathrm{MJ}$, and RW authored the original review and subsequent updates. For the current update, JLB ran the searches, JLB and EN conducted screening and EN and EC conducted data extraction, EN updated the tables, and JLB and EC updated the text and analyses. All authors reviewed, commented on, and approved the final manuscript.

\section{DECLARATIONS OF INTEREST}

JLB: none known

EN: none known

JHB: none known

RW has received payments for lectures, research and consultancy from companies that manufacture smoking cessation medications (Pfizer, GSK, J\&J). He is an unpaid advisor on the Smoke Free smartphone application and to the National Centre for Smoking Cessation and Training.

MJ: none known

EC: none known

$\mathrm{PH}$ was involved in three of the studies included in the review, and has provided consultancy for and received a research grant from Pfizer, a manufacturer of smoking cessation medications.

\section{SOURCES OF SUPPORT}

\section{Internal sources}

- Nuffield Department of Primary Care Health Sciences, University of Oxford, UK.

- National School for Health Research, School for Primary Care Research, UK.

- Queen Mary's School of Medicine and Dentistry, UK.

\section{External sources}

- National Institute for Health Research (NIHR) Cochrane Programme Grant, UK.

\section{DIFFERENCES BETWEEN PROTOCOLANDREVIEW}

As of the last update of the review, meta-analyses of behavioural interventions were changed from a fixed-effect to a random-effects model in line with new Cochrane Tobacco Addiction Group policy, to account for the expected variability in the interventions delivered.

We excluded one previously included study from the last update on the grounds that it included relapsed smokers rather than abstainers (Juliano 2006).

As of this update, we removed the analysis of extended pharmacotherapy in smokers, as this is more extensively covered in individual reviews of pharmacotherapies (Hughes 2014; Cahill 2016; Lindson 2019). As a result of this, we also excluded the previously included study Schnoll 2015. We also ruled that incentives interventions in smokers were ineligible for inclusion in the review, as any incentives intervention could be construed as rewarding participants for not relapsing. Incentives interventions are covered in Notley 2019. 
For the present update, at the request of NICE (the National Institute for Health and Care Excellence; the guideline development organisation for England and Wales), for analyses of studies randomising abstainers, we conducted subgroup analyses grouping studies by the duration of prior abstinence of participants. We grouped studies based on whether participants had been abstinent for four or more weeks, less than four weeks, or if prior abstinence varied or was not adequately specified.

\section{NDEX TERMS}

\section{Medical Subject Headings (MeSH)}

*Secondary Prevention; *Smoking Prevention; Behavior Therapy; Bupropion [therapeutic use]; Chewing Gum; Nicotine [therapeutic use]; Nicotinic Agonists [therapeutic use]; Randomized Controlled Trials as Topic; Smoking Cessation [ ${ }^{*}$ methods]; Smoking Cessation Agents [ ${ }^{\star}$ therapeutic use]; Varenicline [therapeutic use]

\section{MeSH check words}

Female; Humans; Male; Pregnancy 